\title{
Calcined Waste Storage At The Idaho Nuclear Technology And Engineering Center
}

\author{
M. D. Staiger \\ M. C. Swenson
}

January 2005

Idaho National Engineering and Environmental Laboratory Bechtel BWXT Idaho, LLC 
INEEL/EXT-98-00455

Rev. 2

\title{
Calcined Waste Storage at the Idaho Nuclear Technology and Engineering Center
}

\author{
M. D. Staiger
}

M. C. Swenson

January 2005

Idaho National Engineering and Environmental Laboratory Idaho Falls, Idaho 83415

Prepared for the

U.S. Department of Energy

Assistant Secretary for Environmental Management

Under DOE Idaho Operations Office

Contract DE-AC07-99ID13727 


\section{ABSTRACT}

This report documents an inventory of calcined waste produced at the Idaho Nuclear Technology and Engineering Center during the period from December 1963 to May 20(00. The report was prepared based on calciner runs, operation of the calcined solids storage facilities, and miscellaneous operational information that establishes the range of chemical compositions of calcined waste stored at Idaho Nuclear Technology and Engineering Center. The report will be used to support obtaining permits for the calcined solids storage facilities, possible treatment of the calcined waste at the Idaho National Engineering and Environmental Laboratory, and to ship the waste to an off-Site facility including a geologic repository.

The information in this report was compiled from calciner operating data, waste solution analyses and volumes calcined, calciner operating schedules, calcine temperature monitoring records, and facility design of the calcined solids storage facilities.

A compact disk copy of this report is provided to facilitate future data manipulations and analysis. 


\section{SUMMARY}

This report documents an inventory of calcined waste produced at the Idaho Nuclear Technology and Engineering Center during the period from December 1963 to May 2000). The report was prepared based on calciner operating data, waste solution composition and volume information, operation of the calcined solids storage facilities, and miscellaneous operational information that established the range of chemical compositions of calcined waste. The repon will be used to support permitting the calcined solids storage lacilities, treating the calcined waste at the Idaho National Engineering and Environmental Laboratory, and shipping the waste to an off-Site facility including a geologic repository.

Two facilities were used to convert the liquid waste to the solid waste "calcine" at the Idaho Nuclear Technology and Engineering Center. The Waste Calcining Facility operated from December 1963 to March 1981, and converted about 4,165.(00) gal of aqueous nuclear fuel reprocessing waste to about 77.30() $\mathrm{ft}^{3}$ of calcined solids. The New Waste Calcining Facility operated from August 1982 through May 2000), and converted an additional 3,747.000 gal of aqueous waste to about 78.300$) \mathrm{ft}^{3}$ of calcined solids. Refinements in volume calculations in this report resulted in a slight $(<1 \%)$ increase in the volume of stored calcine compared to that of the previous revision.

Waste management strategy may require calcine retrieval and conversion to an alternate waste form. As a basis for planning for this possible conversion, estimates of the chemical and radiochemical compositions of the calcine are provided in this document.

A detailed inventory of the calcined waste in storage at the Idaho Nuclear Technology and Engineering Center was prepared. The inventory revealed that the calcined solids storage facilities are filled as indicated in Table E-1.

Table E-1. Approximate volume of calcine in solids storage facilities.

\begin{tabular}{lcccc} 
Facility & $\begin{array}{c}\text { Total } \\
\mathrm{ft}^{3}\end{array}$ & $\begin{array}{c}\text { Usable } \\
\mathrm{ft}^{3}\end{array}$ & $\begin{array}{c}\text { Filled } \\
\mathrm{ft}^{3}\left(\mathrm{~m}^{3}\right)\end{array}$ & \% Full \\
\hline I & 8,300 & 8,000 & $7,800(222)$ & 97 \\
II & 31,600 & 30,000 & $30,000(851)$ & 100 \\
III & $40,000)$ & 39,900 & $39,500(1120)$ & 99 \\
IV & 17,700 & 17,100 & $17,100(484)$ & 100 \\
V & 36,200 & 35,600 & $35,600(1010)$ & 100 \\
VI & 55,200 & 53,200 & $25,600(724)$ & 48 \\
\hline
\end{tabular}

A compact disk copy of this report is provided to facilitate future datit manipulations and analysis. 


\section{CONTENTS}

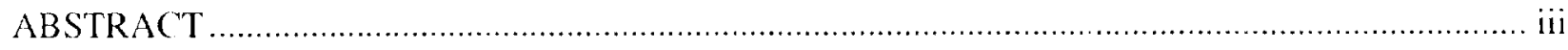

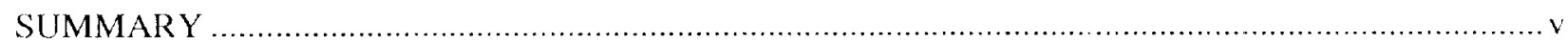

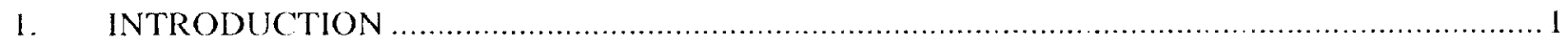

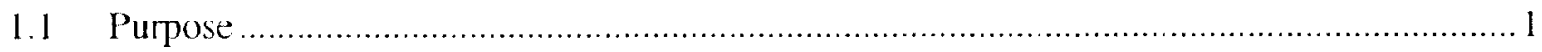

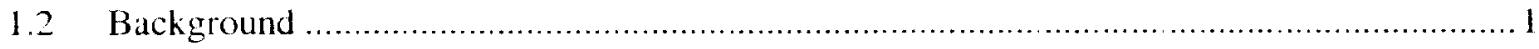

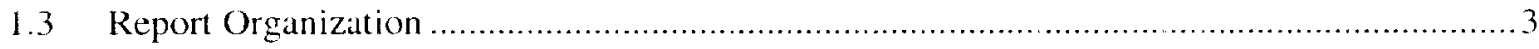

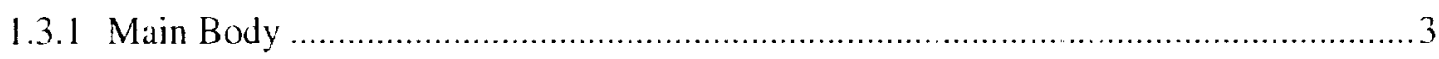

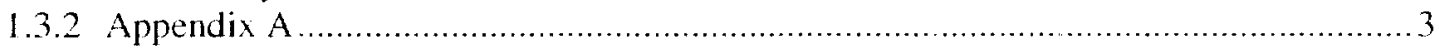

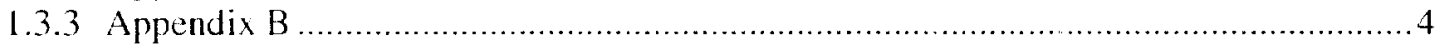

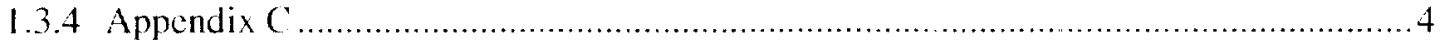

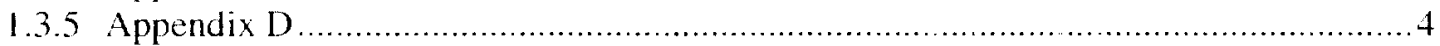

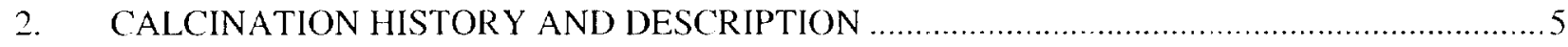

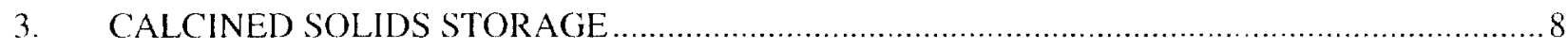

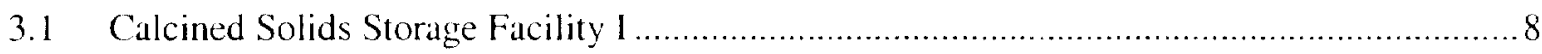

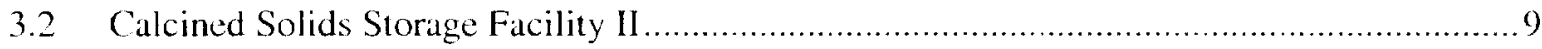

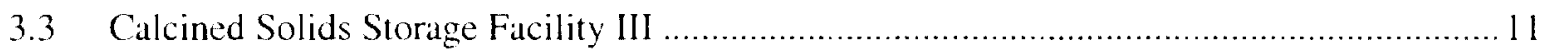

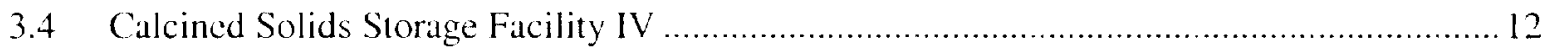

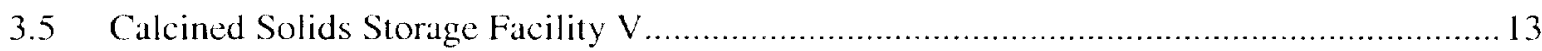

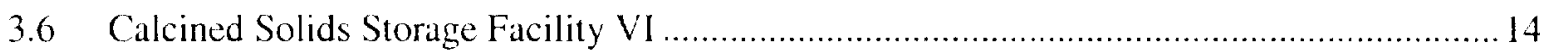

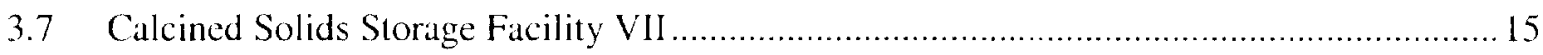

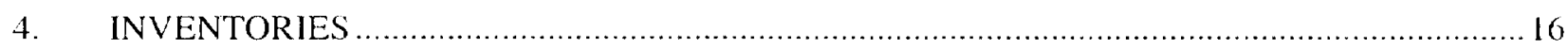

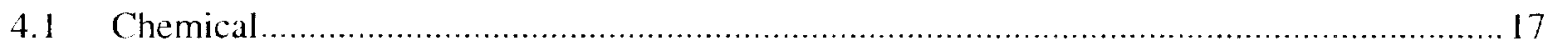

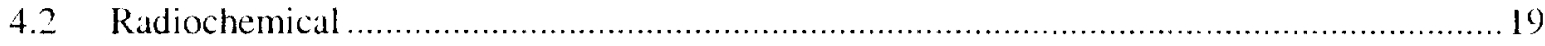

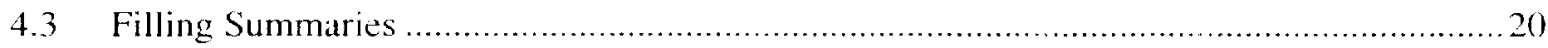

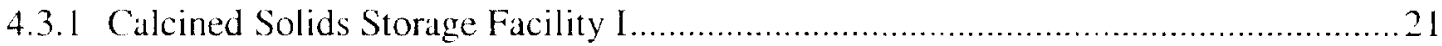

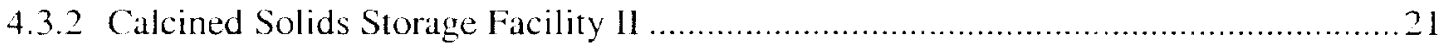

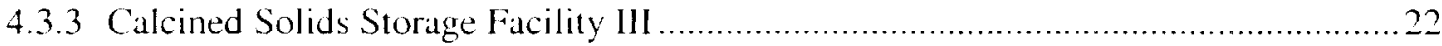

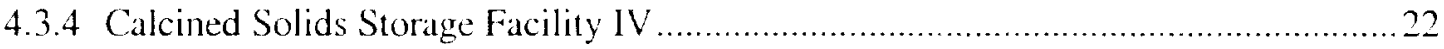

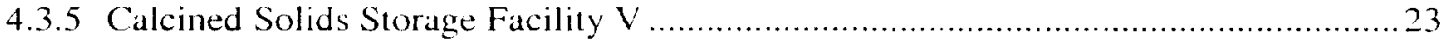




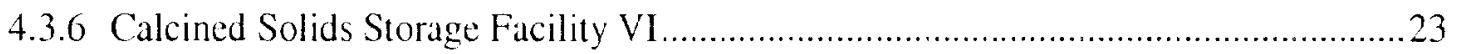

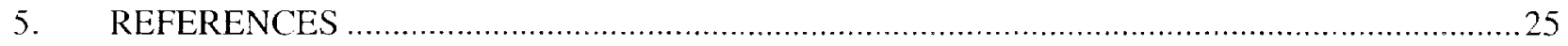

Appendix A -Data and Data Manipulation Summaries ............................................................

Appendix B - Graphical Depictions of Calcination Campaigns ................................................... B-i

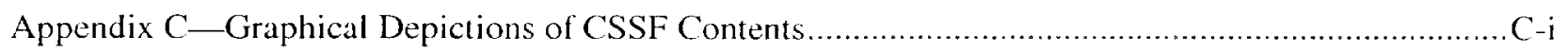

Appendix D-Internally Referenced Documentation ..................................................................

\section{FIGURES}

1. Schematic of the calcining process at the Idaho Nuclear Technology and Engineering Center.........7

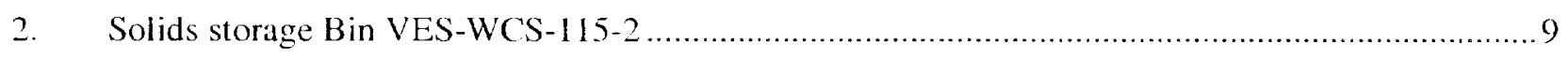

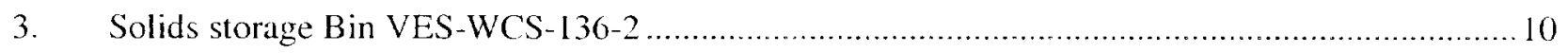

4. Center Bin VES-WCS-140-7 of Calcined Solids Storage Facility III ..................................... 12

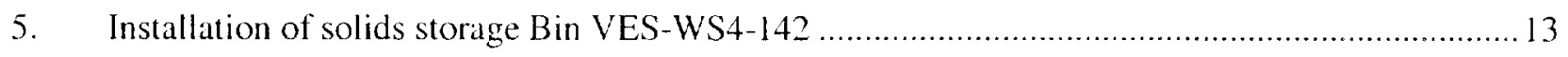

6. Typical bin connection for Calcined Solids Storage Facility V ........................................... 14

7. Distribution piping for Calcined Solids Storage Facility V1 .............................................. 15

\section{TABLES}

1. Approximate volume of calcine in solids storage facilities. .................................................. 2

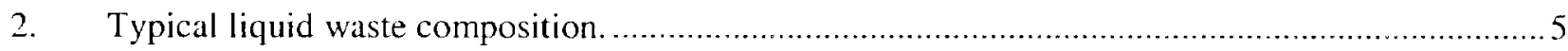

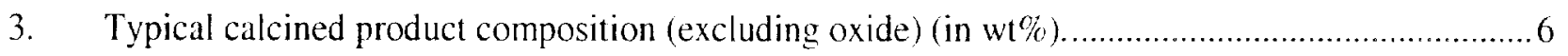

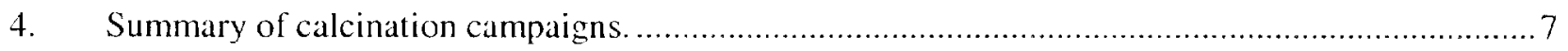




\section{Inventory of Calcined Waste Stored at the Idaho Nuclear Technology and Engineering Center}

\section{INTRODUCTION}

\subsection{Purpose}

This report documents the inventory of calcined waste produced at the Idaho Nuclear Technology and Engineering Center (INTEC) during the period from December 1963 through May 2000). Catcination, developed at INTEC, is the process of converting liquid radioactive waste into a granular solid for storage. The INTEC facility, formerly called the Idaho Chemical Processing Plant. is located at the Idaho National Engineering and Environmental Laboratory (INEEL) in eastern Idaho. This report was prepared based on calciner runs, solids storage facilities operation, and miscellaneous operational information that establishes the range of chemical compositions of calcined waste stored at INTEC. The information in this report includes calciner startup data. waste solution analyses and volumes calcined, calciner operating schedules, calcine temperature monitoring records, capacities, distributor systems, and facility design of the seven calcined solids storage facilities (CSSFs).

This report will be used to support obtaining permits for the calcined solids storage facilities. The report also will be used to support decision making about treating the calcined waste at the INEEL and to ship the waste to an off-Site facility including a geologic repository. If the waste is treated at the INEEL, this report could support the design of waste treatment processes. If the waste is shipped elsewhere for treatment or directly to a geologic repository, this report could support the development of waste shipping methods.

Revision 2 of the report corrects calculation, data entry. and typographic errors that were found in the previous revision. The report has been expanded to include additional hazardous metals regulated by the Resource Recovery and Conservation $\Lambda \mathrm{ct}$ (RCR $\Lambda$ ). Plots of principal constituents are provided that present inventory and concentration data in a more user friendly format. Revised ORIGEN-based estimates of nuclide inventories have been incorporated to provide a more accurate inventory. This revision incorporates a refinement in the accuracy of the calcine inventory estimate and not a change in estimate modeling.

A compact disk copy of this report is provided to facilitate future data manipulations and analysis.

\subsection{Background}

From 1953, the INTEC facility, then called the Idaho Chemical Processing Plant, was used to reprocess spent nuclear fuel. With the end of the Cold War, the Department of Energy announced in April of 1992 that INTEC would no longer reprocess spent nuclear fuel. The final reprocessing activities (uranium recovery) at INTEC were completed in 1994. In 1998, the name of the facility was changed to the Idaho Nuclear Technology and Engineering Center to more closely reflect current research and development missions of the facility.

Since December 1963, fluid-bed calcining was employed at INTEC to convert various types of aqueous nuclear fuel reprocessing waste to a solid form. The waste was processed in a heated fluidized-bed calciner $\left(400\right.$ to $\left.6000^{\circ} \mathrm{C}\right)$ where it underwent thermal decomposition to metallic oxides or fluorides, water vapor, and nitrogen oxides. The solids were transported to stainless steel bins-the CSSFs-for interim storage. 
Seven CSSFs were constructed over the years. Five were filled to capacity or near capacity, the sixth CSSF is partially filled, and the seventh remains unused. Detailed design considerations for these facilities evolved to incorporate operational experience. Calcined storage temperature control was a prime design consideration, and basic bin designs were modified to accommodate the changes in need to remove radioactive decay heat through natural convection. Another major design consideration was the need to provide for calcined product retrieval. Basic design features include welded stainless-steel construction, installed access lines, reinforced concrete vaults, natural convection cooling, and filtered off-gas venting.

Calcined solids are a more stable storage form for the radioactive constituents in waste than liquid, but even more stable long-term storage forms are being investigated. Sometime in the future, the calcined waste may be retrieved and further treated. This report describes the current condition of the calcined solids storage units and the composition of the calcine so that future retrieval and treatment requirements can be quantified. It also provides a single point of reference for future work by assembling the chemical and radiochemical information about the solids and storage configuration into a single document.

Aqueous nuclear fuel reprocessing waste was originally calcined in the Waste Calcining Facility (WCF) (CPP-633) at INTEC and subsequently in the New Waste Calcining Facility (NWCF) (CPP-659). From December 1963 to March 1981. approximately 4,165,000) gal of the waste was converted to about $77,300 \mathrm{ft}^{3}$ of calcined solids at the WCF. From August 1982 through May 2000, about 3,747,000 gal of aqueous waste was converted to $78,300 \mathrm{ft}^{3}$ of calcined solids at the NWCF. Calcination at the NWCF ceased in May of 2000 , pending a decision by the Department of Energy whether to permit or close the facility. Currently, closure work is ongoing for the NWCF calciner.

The CSSFs consist of stainless steel bins (containing the solids) enclosed in concrete vaults to isolate them from the environment. The bin-vault systems are designed to remove the heat generated by the radioactive decay of fission products in the calcine.

Waste management strategy may require calcine retrieval and conversion to an alternate waste form. As a basis for planning for this possible conversion, estimates of the chemical and radiochemical compositions of the calcine layers within bins are provided in this document (in Tables A11 and A12 of Appendix A).

A detailed inventory of the calcined waste in storage at INTEC was prepared from examination of calciner operating data, waste solution composition and volume records, calcined solids storage data, and other operational records. The inventory revealed that the CSSFs are filled as indicated in Table 1.

Table 1. Approximate volume of calcine in solids storage facilities.

\begin{tabular}{ccccc}
\hline Facility & $\begin{array}{c}\text { Total } \\
\mathrm{ft}^{3}\end{array}$ & $\begin{array}{c}\text { Usable } \\
\mathrm{ft}^{3}\end{array}$ & $\begin{array}{c}\text { Filled } \\
\mathrm{ft}^{3}\left(\mathrm{~m}^{3}\right)\end{array}$ & \% Full \\
\hline I & 8,300 & 8,000 & $7,800(222)$ & 97 \\
II & 31,600 & 30,000 & $30.000(851)$ & 100 \\
III & 40,000 & 39,900 & $39,500(1120)$ & 99 \\
IV & 17,700 & 17,100 & $17,100(484)$ & 100 \\
V & 36,200 & 35,600 & $35,600(1010)$ & 100 \\
VI & 55.200 & 53.200 & $25,600(724)$ & 48 \\
\hline
\end{tabular}




\subsection{Report Organization}

The remaining portions of this report are organized as explained below.

\subsubsection{Main Body}

The main body of the report presents historical information about the calcination process at INTEC and characterization of the calcine as follows:

- Section 1.3.2 provides a history of calcination conducted at INTEC

- $\quad$ Section 1.3.3 describes the six CSSFs that contain calcined waste

- Section 1.3.4 characterizes the solid chemical and radioactive calcined waste inventories stored in the CSSFs

- Section 1.3.5 is a list of references cited throughout the report.

In addition, extensive characterization data are appended, the content of which is summarized below. Basic data used in the preparation of this report previously had not been available in a convenient manner, particularly for those not familiar with the use of the documentation recording and retrieval systems at INTEC. The datit has been made more readily available in the voluminous appendixes to this document. Where data were unavailable. estimates were made.

\subsubsection{Appendix A}

Appendix $A$ is a compilation of tables that captures data pertinent to calcine batches in campaigns and summaries of data manipulations of the analytical data. The analytical data were obtained to estimate the composition of the calcine inventory for layers, bin totals, CSSF totals, and total calcine.

- Tables Al through A6 convey the batch feed information for each operational campaign of the original calcining facility, the WCF, and the subsequent calcining facility, the NWCF. Column identifiers are self-explanatory with the exception of the code. The code, sometimes referred to as the stream number, is the feed stream identifier that corresponds to Tables A8 and A10. The circled numbers in Appendix B. Figures B I through B13, likewise correspond to the code numbers. The feed batch data have been carefully compiled from various sources.

- Tables A7 through A10 contain chemical and radiochemical information. Tables A7 and A9 list the chemical and radiochemical sample analyses of liquid feed streams. Tables A8 and Alo contain the estinlated average compositions of the combined feed streams calcined at the WCF and NWCF. The analytical results were adjusted to correct for dilution from steam jet transferring. The analytical results represent the major constituents of concern at the time of analysis. Radiochemical results are given as reported.

- Tables All and Al2 are summaries of the estimated concentrations of chemicals and radiochemical species in the individual layers within the bins in the bin-sets. The calcine layers are dictated by the location of level-indicating thermocouples in the calcine storage bins and do not correspond with changes in calcine composition. The calcine stratification summaries for chemistry were calculated from correlation of feed chemistry and bin filling estimates. 
- Table A13 is the estimated total calcine radionuclide inventory for selected years.

- Table A14 is the estimated radionuclide inventory by individual bin-set for the year 2016 . The radiochemistry results are calculated estimates projected to January 1, 2016.

- Table A15 is the individual CSSF chemical inventory estimate by bin-set.

- Table Al6 summarizes the inventory estimates for RCRA metals by CSSF.

- Table A17 provides individual bin volume, mass, and bulk density estimates.

- Table A18 is a summary of fuel reprocessing campaigns at INTEC with amounts of uranium processed and surmised waste storage tankage.

\subsubsection{Appendix B}

Appendix B contains graphical depictions of the history of calcine processing at INTEC. Figures B 1 through B 13 show the chronology of individual calcination campaigns. These figures identify the waste tank from which waste was calcined and the stream code number which cross-references to the tables in appendix A. The Tank Farm waste volume plots in Figures B 14 through B25 provide a simplified overview of the individual filling and emptying history for the 11 nominal 300,000 -gal liquid waste storage tanks for the period 1953 through 2003. The 11 tanks were constructed from the early $1950 \mathrm{~s}$ to the mid 1960s and were the principal vessels used for temporary storage of the liquid radioactive waste from INTEC fuel reprocessing. Figures B26 through B31 show the individual bin filling chronology

\subsubsection{Appendix C}

Appendix $\mathrm{C}$ presents plots of the calcine inventories in units ( $\mathrm{wt} \%, \mathrm{ppm}, \mathrm{Ci} / \mathrm{m}^{3}$ and $\mathrm{nCi} / \mathrm{g}$ ) normally used by regulators. Their presentation is intended to help minimize unit conversion calculations and the potential errors in such conversions.

\subsubsection{Appendix D}

Appendix D contains copies of the internal documents cited in footnotes throughout the report. These are attached as an aid to the user. 


\section{CALCINATION HISTORY AND DESCRIPTION}

Radioactive liquid waste at INTEC is a by-product of nuclear fuel reprocessing activities. The waste resulted principally from nuclear fuel dissolution, decontamination operations, and uranium recovery by solvent extraction. The waste was stored in the INTEC Tank Farm before being calcined. Figures B 14 through B24 in Appendix B illustrate the operational history of the Tank Farm. The charts present a qualitative overview of waste management at INTEC. A historical review of high-level waste management at INTEC was published in the May 1997 issue of Radwaste Magazinc.'

Fluidized-bed calcination is a unique process developed for liquid waste treatment at INTEC. At the heart of the waste calcining process is a high-temperature fluidized bed. During calcination, radioactive waste solutions is fed through pneumatic atomizing nozzles into a heated bed of air-fluidized granular solids. The liquid portion of the waste is evaporated and the dissolved solids in the liquid are converted to a solid granular material. The undissolved and dissolved solids in the liquid solutions are made up of about 99 wt \% nonradioactive material and 1 wt \% radioactive waste. Typical waste compositions for unadjusted calciner feed from the Tank Farm are given in Table 2.

Table 2. Typical liquid waste composition.

\begin{tabular}{llcccc}
\hline Major Species & Units & Aluminum & Zirconium & Fluorinel & SBW \\
\hline Acid $\left(\mathrm{H}^{+}\right)$ & molar & 0.81 & 1.40 & 1.50 & 1.28 \\
Aluminum & molar & 1.51 & 0.68 & 0.43 & 0.57 \\
Boron & molar & & 0.19 & 0.15 & 0.017 \\
Cadmium & molar & & & 0.05 & 0.001 \\
Chloride & mg/L & & 50 & 1,000 \\
Chromium & molar & & 0.015 & 0.002 & 0.001 \\
Fluoride & molar & & 3.2 & 2.10 & 0.04 \\
Iron & molar & 0.01 & 0.007 & 0.005 & 0.002 \\
Mercury & molar & 0.02 & & & .0013 \\
Nitrate & molar & 5.4 & 2.3 & 1.90 & 4.5 \\
Potassium & molar & & 0.003 & 0.005 & 0.17 \\
Sodium & molar & 0.06 & 0.017 & 0.02 & 1.5 \\
Sulfate & molar & 0.014 & & 0.035 & 0.043 \\
Tin & molar & & 0.005 & 0.003 & 0.03 \\
Zirconium & molar & & 0.41 & 0.31 & \\
\hline SBw sodium-bearng waste & & & & \\
\hline
\end{tabular}

The principal reactions during calcination are evaporation and thermal decomposition of the solutions to metallic oxides or fluorides, water vapor, and nitrogen oxides. Average calcined product compositions are given in Table 3. Solid product builds up in layers on the bed particles while gases and some of the finer solids (less than $0.10 \mathrm{~mm}$ diameter) are swept from the vessel with the fluidizing 
Table 3. Typical calcined product composition (excluding oxide) (in wt\%).

\begin{tabular}{lcccc} 
& Aluminum & Zirconium & Fluorinel/SBW & Aluminum Nitrate/SBW \\
\hline Aluminum & 87.3 & 11.8 & 6.5 & 53.4 \\
Boron & 0.4 & 1.1 & 1.0 & 0.8 \\
Cadmium & & & 5.5 & 0.2 \\
Calcium & & 37.7 & 31.9 & 4.0 \\
Chloride & & 0.4 & 0.1 & 0.4 \\
Chromium & & 30.1 & 0.1 & 0.1 \\
Fluoride & 0.1 & 0.3 & 21.9 & 1.0 \\
Iron & 5.5 & & 0.2 & 0.4 \\
Mercury & 2.6 & 0.1 & 0.001 & 0.003 \\
Nitrate & 0.1 & 0.1 & 8.1 & 23.0 \\
Potassium & 1.4 & & 0.9 & 2.5 \\
Sodium & 1.5 & 0.3 & 4.1 & 11.4 \\
Sulfate & & 18.2 & 3.7 & 1.4 \\
Tin & & 0.2 & 0.3 \\
Zirconium & & 15.5 & \\
\hline SBW = sodium-hearing waste & & & & \\
\hline
\end{tabular}

gases. The average bed particle size is kept at the desired value (approximately 0.3 to $0.7 \mathrm{~mm}$ in diameter) by controlled attrition of bed particles, which is achieved by varying the volumetric ratio of atomizing air to liquid feed.

The bed level is maintained above the feed spray zone so that feed spray contacts fluidized-bed particles. The details of the calcination process used in the WCF and the NWCF are discussed extensively in the facility safety analyses. ${ }^{2.3}$ Figure 1 depicts the calcination process.

Two different methods were used to supply process heat for the decomposition reaction. Heat for the first three WCF processing campaigns was supplied by circulating molten sodium-potassium eutectic liquid metal alloy (NaK) through an internal heating-tube bundle. ${ }^{+}$Decomposition heat for the remaining campaigns was supplied by the direct "in-bed" combustion of oxygen-atomized kerosene.

Solid product (calcine) is transported from the calciner to the storage bins, from two sources, by means of pneumatic-conveying equipment. The bed product is removed directly from the fluidized bed through "take-off' lines connecting the calciner and the product-transfer system. "Fines" elutriated from the calciner with the off-gas are separated from the off-gas with a cyclone. The fines are transferred to the solids transport line where they combine with the bed product removed from the calciner. This combined stream is transported to a second cyclone above the storage bins where it is separated from the transport air. The solids fall by gravity into the calcine storage bins, and the transport air is returned to the calciner for decontamination with the process off-gas.

A summary of the volumes of liquid waste calcined over the years is presented in Table 4. Detailed operational chronologies for the various calcination campaigns are presented in Figures B1 through B 13 in Appendix B. 


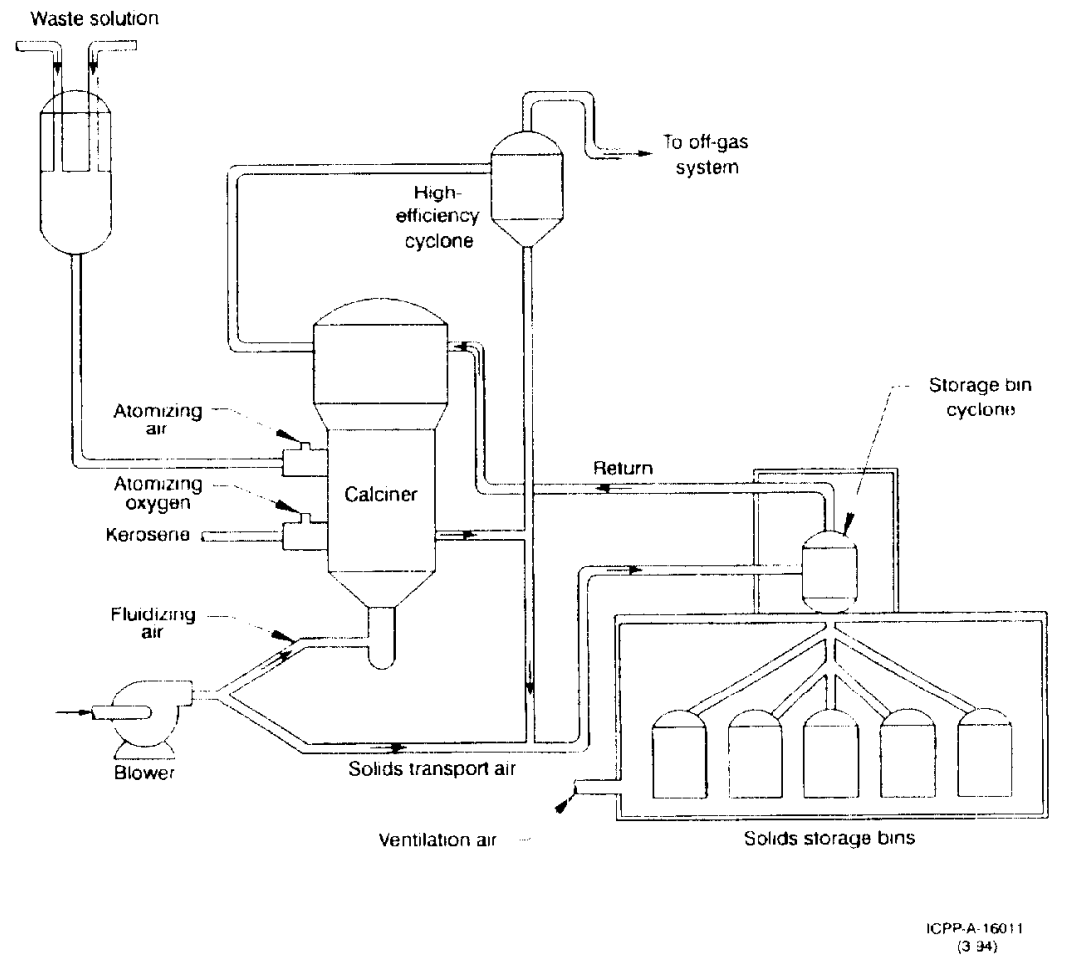

Figure 1. Schematic of the calcining process at the Idaho Nuclear Technology and Engineering Center.

Table 4. Summary of calcination campaigns.

\begin{tabular}{|c|c|c|c|c|c|}
\hline Campaign & Date & $\begin{array}{c}\text { Liquid to } \\
\text { Calciner } \\
\text { (gal) }\end{array}$ & $\begin{array}{l}\text { Liquid to Tank } \\
\text { Farm (gal) }\end{array}$ & $\begin{array}{c}\text { Solids Stored } \mathrm{ft}^{3} \\
\left(\mathrm{~m}^{3}\right)\end{array}$ & $\begin{array}{c}\text { Net Volume } \\
\text { Reduction }\end{array}$ \\
\hline WCF I & Nov 1963 to Oct 1964 & 512,000 & 8.100 & $7.800(222)$ & 8.7 \\
\hline WCF 2 & Mar 1966 to Mar 1968 & 989,000 & 147,800 & $13,000(368)$ & 8.6 \\
\hline WCF 3 & Aug 1968 to Jun 1969 & 329,000 & 67,400 & $5,500(157)$ & 6.4 \\
\hline WCF 4 & May 1970 to Jan 1971 & 225,000 & 26,500 & $5,200(147)$ & 5.1 \\
\hline WCF 5 & Sept 1971 10 Apr 1972 & 300,000 & 66,000 & $7,200(204)$ & 4.3 \\
\hline WCF 6 & May 1973 to May 1974 & 386,000 & 78,900 & $9,100(259)$ & 4.5 \\
\hline WCF 7 & May 1975 to Jan 1977 & 375,000 & 19,500 & $9.300(26.3)$ & 5.1 \\
\hline WCF 8 & Sep1 1977 to Sep1 1978 & 469.500 & 50,100 & $10,700(303)$ & 5.2 \\
\hline WCF 9 & Jun 1979 to Mar 1981 & 476,000 & 162,900 & $9,500(270)$ & 4.4 \\
\hline NWCF 1 & Aug 1982 to Jun 1984 & $1,553,000$ & 98.700 & $27,200(771)$ & 7.1 \\
\hline NWCF 2 & Sept 1987 to Der 1988 & 797,800 & 165,200 & $16,500(469)$ & 5.1 \\
\hline NWCF 3 & Dec 1990 to Nov 1993 & 744,500 & 183,600 & $16,400(465)$ & 4.6 \\
\hline NWCF 4 & May 1997 to May 2000 & 754.500 & 97,100 & $18,100(513)$ & 4.9 \\
\hline Total & & 7.911 .300 & 1.171 .800 & $155,500(4.411)$ & 5.8 \\
\hline
\end{tabular}




\section{CALCINED SOLIDS STORAGE}

The solids produced by the waste calcining process are stored in stainless-steel bins housed in reinforced concrete vaults. ${ }^{5}$ The bins provide for cooling for the calcine and isolate the calcine and its radioactive and hazardous components from the environment. A description of the unique characteristics of each storage facility is given below. The bulk of the information contained in this section was obtained through examination of designer and fabricator drawings.

The volume of calcine stored at INTEC has been tracked for a number of years at $4386 \mathrm{~m}^{3}$. Tables in this report differ slightly from this number. Rounding and filling cut-off points are subject to differences. Every effort has been made to provide an accurate volume estimate. This report estimates the volume at approximately $4411 \mathrm{~m}^{3}$. No additional calcine has been generated or stored since May 2000 . The small difference in reported volumes is due to refinement in vessel volume calculations.

\subsection{Calcined Solids Storage Facility I}

Calcined Solids Storage Facility I, also known as Bin Set 1, consists of four composite bins (somelimes referred to as groups), VES-WCS-1 15-1, -2, -3, and -4, and three sub-bins, numbered from inside to outside, A-1, A-2, and A-3. The Fluor Corporation of Los Angeles designed the facility. Oscar Krenz of Berkeley, California, fabricated the bins in 1959 of Type-405 stainless steel.

The innermost cylindrical sub-bins, are approximately $25 \mathrm{ft}$ tall (except for VES-WCS-115-4, which is about $27 \mathrm{ft}$ tall) and $3 \mathrm{ft}$ in diameter. The wall thickness varies from $0.125 \mathrm{in}$. at the bottom to $0.25 \mathrm{in}$. at the top, with the bottom head being $0.325 \mathrm{in}$. Each annular bin is approximately $20 \mathrm{ft}$ tall. The inner annular bins have a $4 \mathrm{I}$-in. inside diameter and a 9 )-in. outside diameter. The material thickness for these bins varies from $0.325 \mathrm{in}$. on the bottom to $0.25 \mathrm{in}$. on top, with $0.125 \mathrm{in}$. on the inner wall and 0.1875 in. on the outer wall. The outer annular bins have a 94 -in. inside diameter and a 142 -in. outside diameter. The material thickness for the outer annular bins is $0.325 \mathrm{in}$. on the bottom and $0.25 \mathrm{in}$. on top with $0.1875 \mathrm{in.}$ on the walls. No retrieval access was provided for these bins. The estimated usable capacity of the four bins is approximately $8.000 \mathrm{ft}^{3}$. Figure 2 depicts the initial installation of Bin VESWCS 1152.

The bins contain numerous internal obstructions, such as thermowells, internally mounted wall stiffeners, and bottom braces that could hinder calcine retrieval operations. Near the completion of bin filling operations, physical measurement of the solids level in the VES-WCS-115-4-A-3 sub-bin was accomplished with a bolt-weighted string. After it was used, the measurement material purposely was allowed to fall into the bin. Production records indicate that the measurement was made at least three times through the Can Disposal Line, 4-in. PWA-3083. The external bin surfaces are likewise encumbered with instrument junctions, electrical conduits, process piping, and structural members.

In April 1979, an estimated 250 to 750 gal of water entered the CSSF I vault. ${ }^{\text {a }}$ The water source was a ruptured nearby underground water line, but the vault entry mechanism was not determined. The water level decreased over time without operational intervention. The water level did not raise high enough to touch the bins or interrupt convective cooling airflows. In 1995, a vault inspection ${ }^{6}$ via remote video confirmed the undisturbed condition of the bins. No deterioration of the calcined product or bins is expected.

a. S. S. Bodner to M. B. Heiser. "Water Ingress to Bin Sel Vaults," Bod-06-92, Interdepartmental Correspondence. Idaho National Engineering Laboratory. Westinghouse Idaho Nuclear Company, Idaho Falls, Idaho, May 22, 1992. 


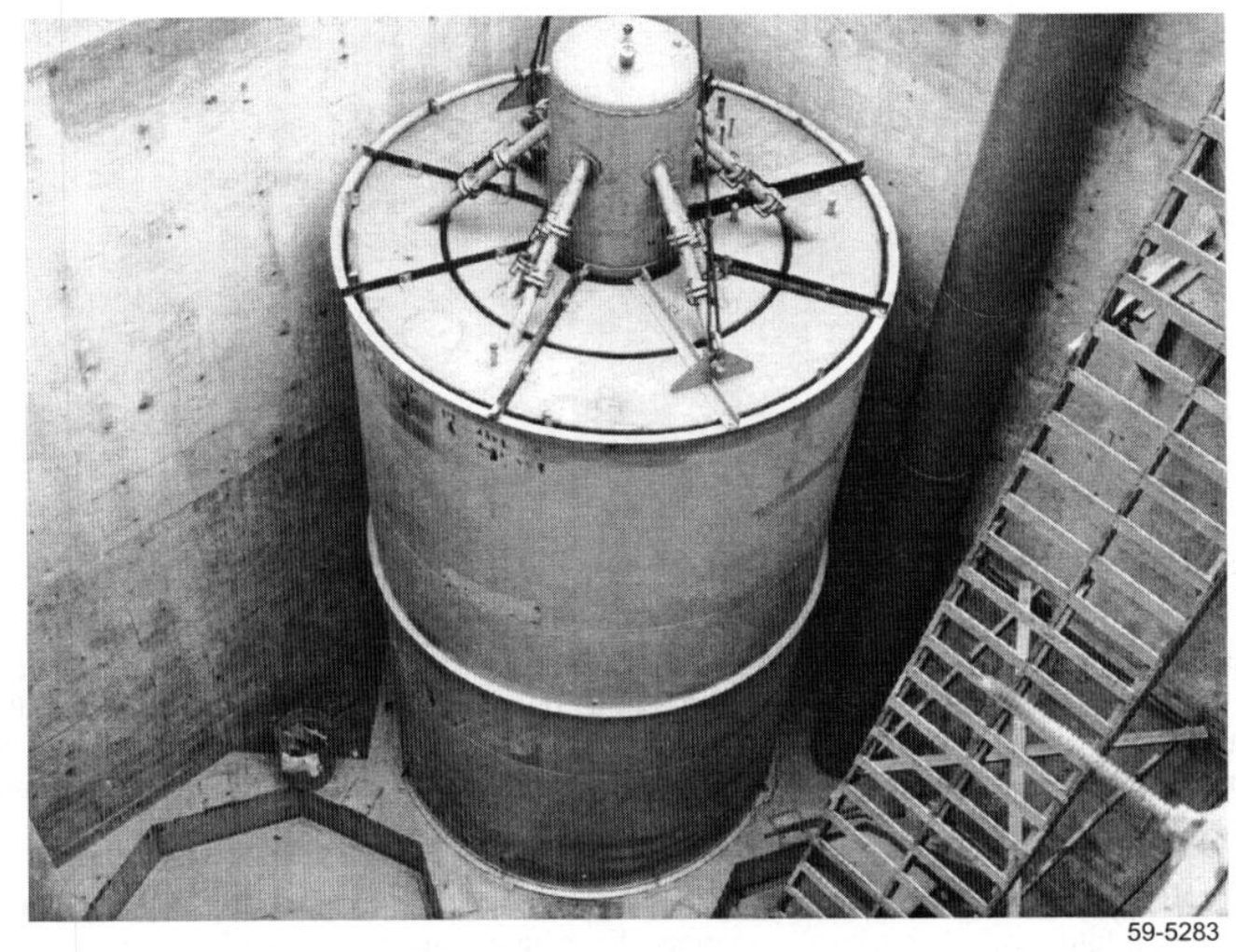

Figure 2. Solids storage Bin VES-WCS-115-2.

\subsection{Calcined Solids Storage Facility II}

Calcined Solids Storage Facility II, also known as Bin Set 2, consists of seven bins: VES-WCS-136-1 through -7. The facility was designed by Norman Engineering of Los Angeles. Each bin is a standard right circular cylinder. Chicago Bridge and Iron Works Company, Western Operations, located in Salt Lake City, fabricated the bins in 1965 of Type-304 stainless steel.

Each bin is about $42.3 \mathrm{ft}$ tall with a $12-\mathrm{ft}$ diameter. ${ }^{7}$ Figure 3 depicts Bin VES-WCS-136-2 prior to installation. The vessel walls are $0.25 \mathrm{in}$. thick. The usable volume of the CSSF is approximately $30,000 \mathrm{ft}^{3}$. Each bin is fitted with a 6-in., Schedule 40, retrieval nozzle. Attached to each of these seven nozzles is a 6-in., Schedule 40S, 27 -ft-long access riser. Five nozzles terminate in a 6-in., welded cap and two terminate in a 150-lb, weld-neck flange. Two flanged retrieval lines are embedded in concrete. They are installed with expansion bellows. Six access lines rise vertically from the tank nozzle, and the seventh rises at 6.5 degrees from vertical and terminates through a 9-ft-shielded, penetration bend arrangement.

The principal internal obstructions to calcine retrieval are thermowells and corrosion coupons. The thermowells are centerline-mounted, 1-1/2-in., Schedule 160, pipes with associated support hardware. In addition, all bins have a wall-mounted thermowell that enters the vessel wall approximately $11 \mathrm{ft}$ from the top of the vessel and extends down and attaches to the inside surface $4 \mathrm{ft}$ below. Bins VES-WCS-136-1 and -4 have an additional wall mounted thermowell approximately $11 \mathrm{ft}$ lower. Bins VES-WCS-136-1 and -4 also have an array of 12 thermocouples, which were installed to monitor the temperature gradient radially from the bin's centerline. These thermowells and their support hardware could pose a hindrance to remote operations. Each bin has four internally attached stiffening rings, approximately $5 \mathrm{in}$. wide, that 


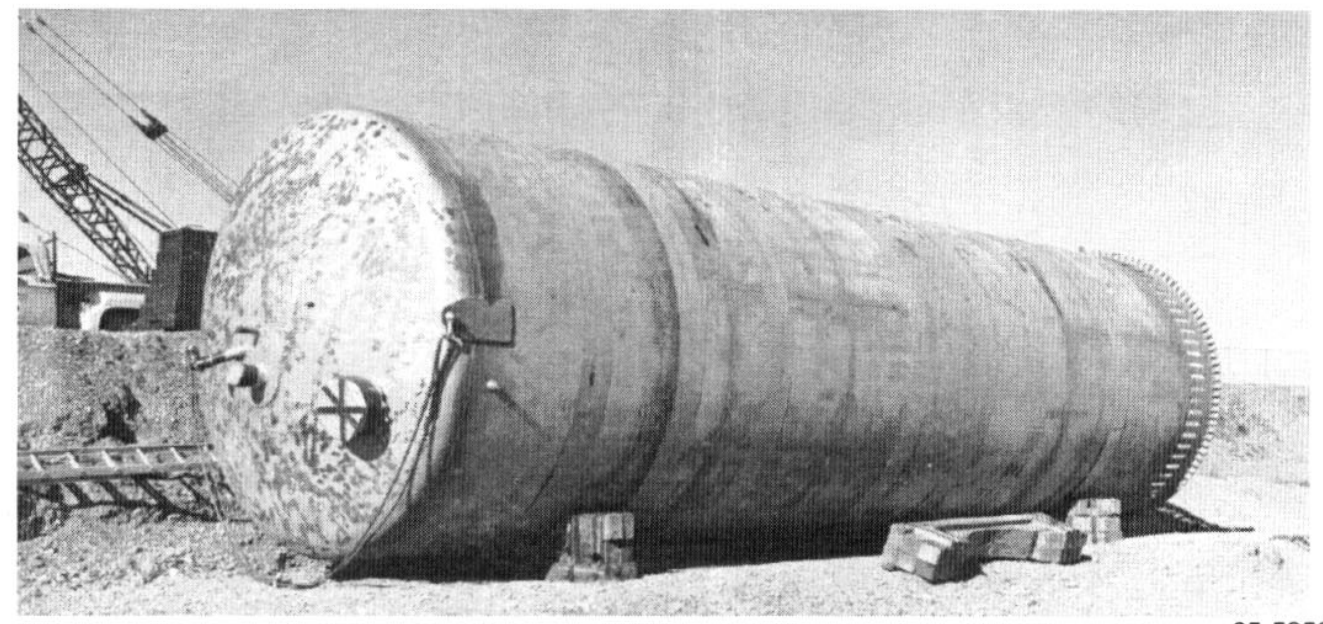

$65-5256$

Figure 3. Solids storage Bin VES-WCS-136-2.

are separated roughly equidistant down the bin wall. Two bins have corrosion coupons suspended separately from wall-mounted hangers. One bin has four coupon cables, and the other has three. Prior to sampling the calcine stored in Bins VES-WCS-136-3 and -7 in May 1978, temporary ventilation control equipment was installed on the Bin VES-WCS-136-1 riser. During the installation, a cable of coupons was dropped inside the vessel. ${ }^{\mathrm{b}}$

That cable remains unretrieved in the bin at this time. The loose coupon cable and could pose difficulties during future calcine retrieval operations. Each bin is equipped with a 1-1/2-in., screwed, test vent and drain at the tangent of the top head. The vent-and-drain nozzle is approximately 2 in. long. A detail of the nozzle closure is shown in the Chicago Bridge and Iron Works fabricator print but not in the plant drawings. The fabricator print shows that the screwed plugs were back-welded. The construction photos show the high placement of the fitting. Access to this recessed spot may pose difficulties for retrieval of the small amount of calcine in the nozzle.

When CSSF II was nearly full, a lead-weighted string was used to measure the solids level in two bins. After use, the measurement material was allowed to fall into the bin to prevent the spread of radioactive contamination. Three measurements were made in Bin VES-WCS-136-2: the first on September 20, 1971; the second on October 21, 1971; and the last on November 24, 1971. At least two measurements were made in Bin VES-WCS-136-6: one on September 20, 1971, and the second on October 21, 1971. Plant drawings indicate that Bins VES-WCS-136-2 and VES-WCS-136-6 are capped. Removable connections are required to provide access for making these types of measurements. Access to Bin VES-WCS-136-2 was gained in 1972 for off-gas sampling through a 2-in. screw-cap nipple installed on the terminating weld cap of the retrieval line. ${ }^{c}$ Bin VES-WCS-136-6 could be modified similarly. During the 1978 calcine sampling operations in Bin VES-WCS-136-3, ${ }^{8}$ a section of sample piping dropped into the bin. Also, the bin off-gas line was plugged with calcine or some other foreign material.

b. J. S. Schofield to B. S. Musgrave, "Dropping of Corrosion Coupons into Bin Set \#2," JSS-11-78, Internal Correspondence, Idaho National Engineering Laboratory, Allied Chemical Corporation, Idaho Falls, Idaho, May 26, 1978.

c. W. B. Palmer to G. E. Lohse, "Gas Sampling of Solids Storage Bins," WBP-1-72, Internal Correspondence, National Reactor Testing Station, Allied Chemical Corporation, Idaho Falls, Idaho, August 9, 1972. 
An crosion failure in the transport system piping or cyclone in the eyclone vault is possible. Calcine transport system anomalies oceurred" about the time of switchover from CSSF II to eSSF III; however, documentary evidence of a failure could not be located in the production records. For planning purposes, one should assume that the cyclone vault may be contaminated with radiobetive calcine.

\subsection{Calcined Solids Storage Facility III}

Calcined Solids Storage Facility III, also known ats Bin Set 3, consists of seven bins: VES-W(S-140-1, -2, -3, -4, -5, -6 and VES-WCS-139. which wals later renamed VES-WCS-140-7 in some plant documentation. The bins in CSSF III are similar to those in CSSF II, exeept that the center bin (VES-WCS-139) is taller than the other six as depicted in Figure the The facility was designed by ldallo Nuclear Corporation of Idaho Falls, Idaho. Capital Westward of Paramount, Calilornia, fabricated each bin in 1969 from Type 304 stainless sted. Six of the 12-fi-diameter bins are approximately 53 fi tall. The seventh bin is 61 fi tall. The bin walls range in thickness from $0.25 \mathrm{in}$ at the top 100.4375 inl. at the bottom. The usable volume of the ('SSF is approximately $39.900 \mathrm{ft}^{3}$. Each bin is fitted w ith a 6 -inl., Schedule 40S, retrieval nozzle. Attached to each noryle is an acess line is ti long and capped with a $6-$ in.. 150-lb. weld-neck tlinge.

Internal obstructions to calcine retrieval operations include centerline-mounted, 2-in.. Schedule 80, thermowells with their associated support hardware, and five sets of corrosion coupons hung from hangers attached to the wall of Bin VES-WCS-140-1. The corrosion coupons are installed through one of the two retricval norsles. They are secured from a $1 / 4$-in. J hook welded to the insiele of the retrieval riser $4105 \mathrm{in}$. from its opening. These $J$ hooks and the corrosion coupons will have to be removed before any retrieval activities through the noyle can start. Bins VES-WCS-140-1 through -6 have six internally altached stiffening rings, approximately 5-int-wide, mounted roughly equidistant down the bin wall. Bin VES-WCS-139 has seven.

Each bin is equipped with a 2 -in. test vent at the tangent of the bottom heid. The noz/le is approximately 2 in. long and capped with a weld eap. 11 maly be difficult to retrieve the small amount of calcine in the nozzle.

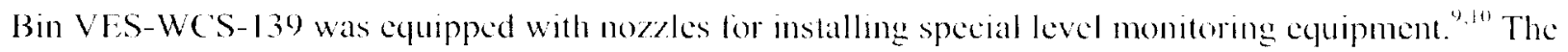
design review packages for this bin often refer to the design and installation of special hardwalre, a capacitance probe and an ultasonic probe. The construction photograph in Figure 4 shows the capacitance probe nozze terminated in the valut area immediately above the bin with what appears 10 be a threaded cap base on a recommendation from the Technical Department that the capacitance probe not be installed because of vault acess misalignment'. Documentation verifying the status of the ultrasonic probe installation was not localed. If installed, the presence of the ultrasonic probe is not expected to be a significant hindrance to retrieval operations. Technical personncl indicaled that any measuring equipment would be installed in a 6-in. riser.

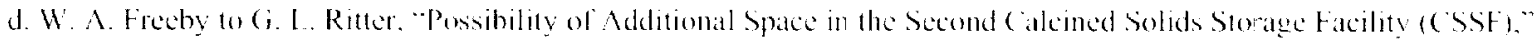

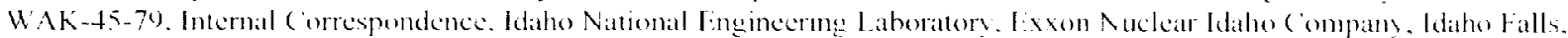
Idaho. September 6, 1974)

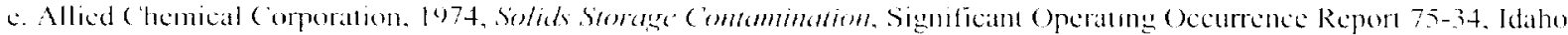
National lengincering Laboratory, ldaho Falls, Kaho, March 3. 19\%6.

f. L.. A. Jobe to (i. V. Markham, "Solids Storage Bin Solids Level Detector Connection," Jobe-2-71. Internal Correspondence. National Reactor Testing Station. Idaho Nucluar Corperation, Idaho Falls. Idaho. April \&. 147I. 


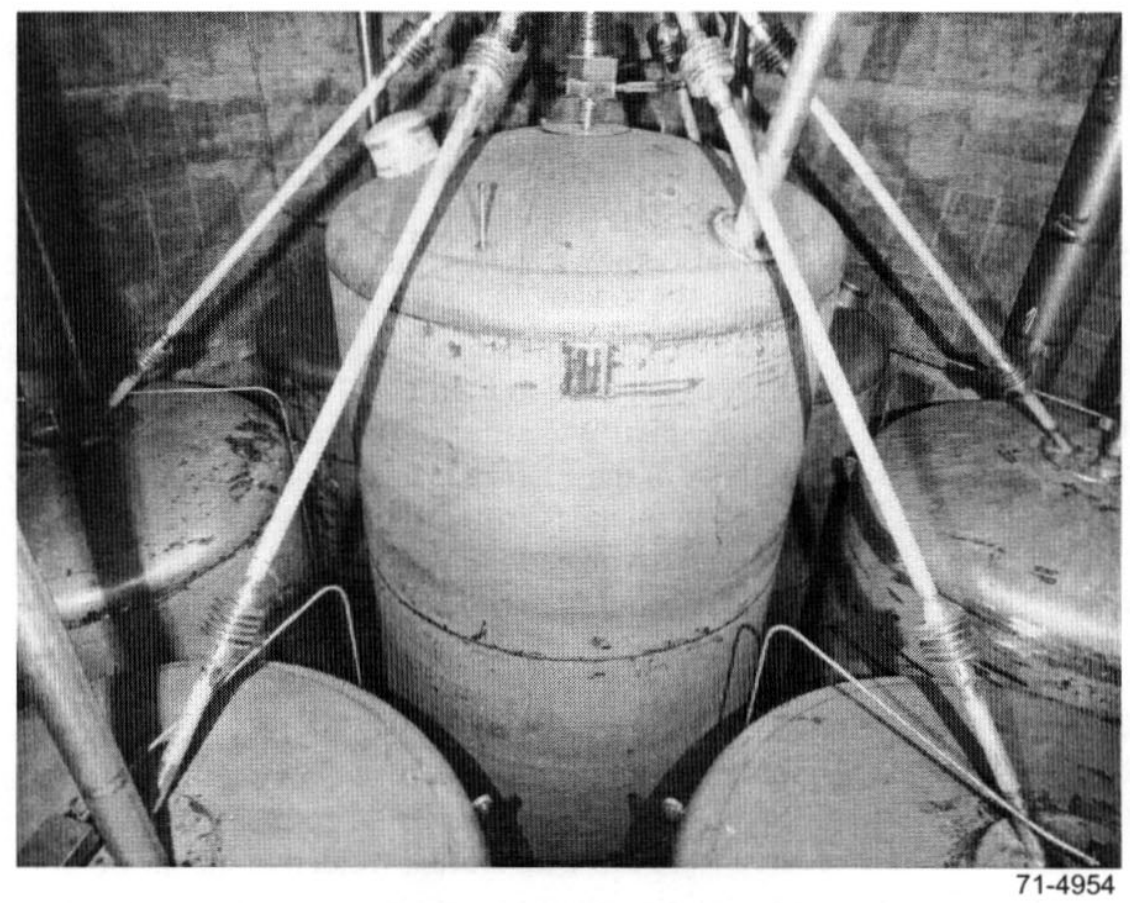

Figure 4. Center Bin VES-WCS-140-7 of Calcined Solids Storage Facility III.

Frequent plugging of the distribution piping was experienced while filling CSSF III. Auger type clearing was necessary on several occasions. Although no documentary evidence was found, workers remember losing long cable sections on two different occasions.

According to production records, two erosion failures occurred in the inlet line to the cyclone for the facility, one in October 1976 and the other in December 1977. The vault required extensive cleanup before the failed equipment was replaced. Erosion caused a third failure but no calcine was released because the second fix installed a backup wear pad. For planning purposes, one should assume that relatively high contamination levels exist in the cyclone vault.

\subsection{Calcined Solids Storage Facility IV}

Calcined Solids Storage Facility IV, also known as Bin Set 4, consists of Bins VES-WS4-142, -143 , and -144 , which are similar to the CSSF III bins except that the stiffening rings are attached externally. Aerojet Nuclear Company of Idaho Falls, Idaho, designed the facility. Capital Westward of Paramount, California, fabricated the bins in 1976 of Type-304 stainless steel.

Each bin is approximately $55 \mathrm{ft}$ tall with a 12 - $\mathrm{ft}$ diameter. ${ }^{11}$ The bin walls range in thickness from $0.375 \mathrm{in}$. at the top to $0.625 \mathrm{in}$. at the bottom. The usable volume of CSSF IV is approximately $17,100 \mathrm{ft}^{3}$. Each bin is fitted with two 6-in., Schedule 80, retrieval nozzles. (Note that the Capital Westward fabrication print shows the nozzle fitted with Schedule 80 steel, while the plant drawing shows Schedule 40.) Attached to each nozzle is an 18-ft-long access line capped with 6-in., 150-lb, weld-neck flange.

Internal obstructions to calcine retrieval operations are centerline-mounted, 2-in., Schedule 80, thermowells with their associated support hardware, and five sets of corrosion coupons hung from 
separate hangers attached to the wall in each of the bins. The strings of corrosion coupon are installed through one of the two retrieval nozzles for each bin. They are secured to $1 / 4-\mathrm{in}$. J hooks welded to the inside of the riser 4 to $5 \mathrm{in}$. from its opening. These $\mathrm{J}$ hooks and the corrosion coupons should be removed before retrieval activities through any of these three nozzles.

Each bin is equipped with a 4-in. seal-welded test vent at the tangent of the bottom head. These nozzles are 4 in. long and capped with a weld cap. The vents are not shown on the plant drawing but can be seen on the installation photos. It may be difficult to retrieve the small amount of calcine in the nozzle.

Figure 5 shows Bin VES-WS4-142 during placement. The 4-in. test vent and drain nozzle is visible on the bottom left just above the ventilation skirt. The bin stiffening rings are clearly visible.

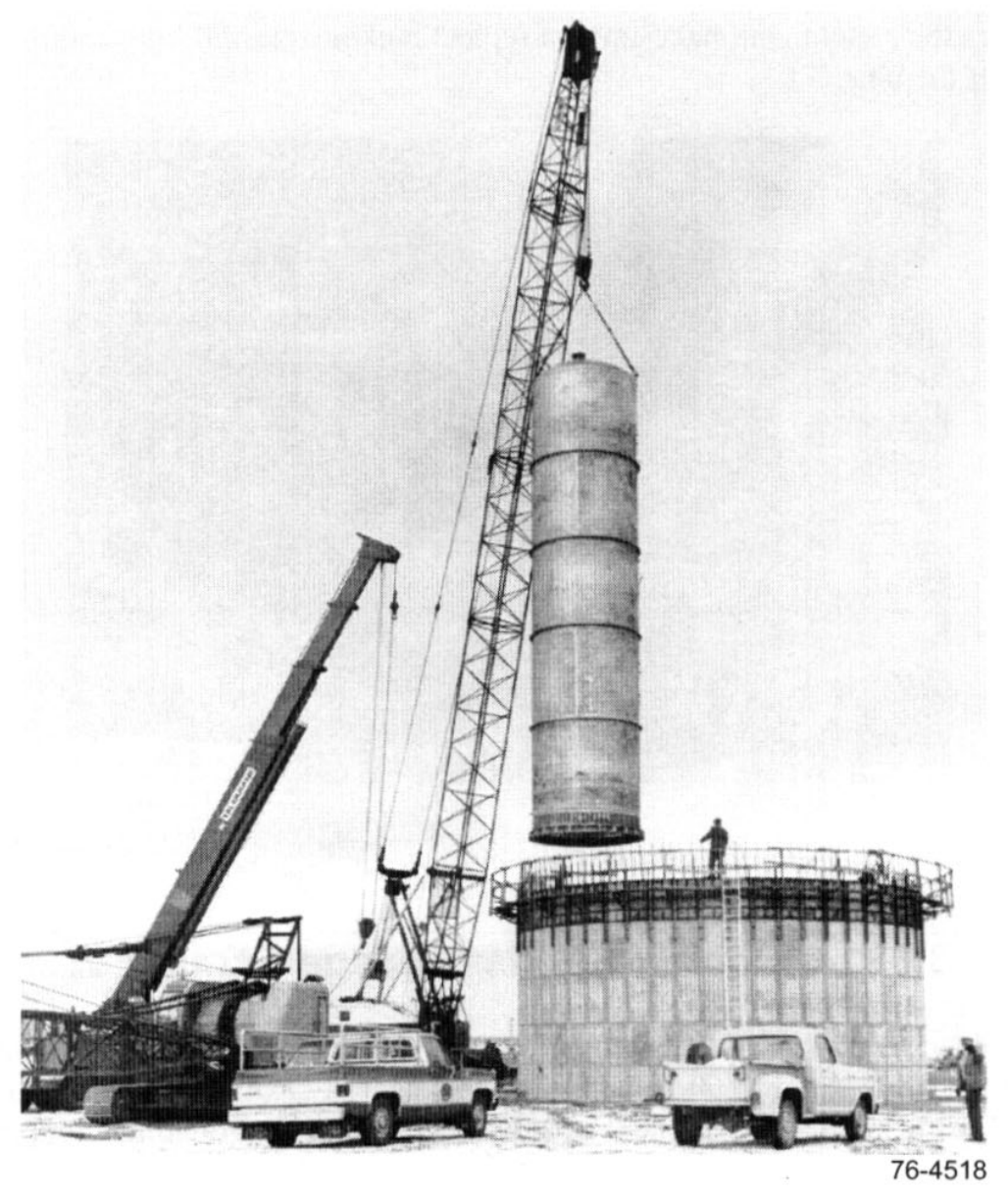

Figure 5. Installation of solids storage Bin VES-WS4-142.

\subsection{Calcined Solids Storage Facility V}

Calcined Solids Storage Facility V, also known as Bin Set 5, consists of seven annular bins, VES-WS5-146, through -152, arranged similarly to those in CSSF III. Facility design was by EG\&G Idaho of Idaho Falls, Idaho. Capital Westward of Paramount, California, fabricated the bins in 1978 from Type-304L stainless steel. Capital Westward identified the bins as WCS and not as WS5. Each bin is approximately $50 \mathrm{ft}$ tall with 12 - $\mathrm{ft}$ outer and 4 - $\mathrm{ft}$ inner diameters. ${ }^{12}$ The outer wall thickness varies from 
$0.625 \mathrm{in}$. at the bottom to $0.375 \mathrm{in}$. at the top, while the inner wall thickness is $0.375 \mathrm{in}$. throughout. The usable volume of CSSF V is approximately $35,600 \mathrm{ft}^{3}$. Each bin is fitted with four 8 -in., Schedule 40, retrieval access risers capped with an 8-in., 150-lb, weld-neck flange. Each riser exits vertically from its vessel connection. Twenty-two risers are $24 \mathrm{ft}$ long, four risers are $36 \mathrm{ft}$ long, and two risers are $37 \mathrm{ft}$ long. Internal obstructions to retrieval operations are two 2-in., Schedule 80, thermowells with their support hardware. Five sets of corrosion coupons are hung on separate hangers in 6-in., Schedule 40, retrieval access risers in Bins VES-WS5-149 and VES-WS5-155.

Capital Westward fabricator prints show each bin equipped with a 1-in. seal-welded, screwed, hydrostatic test vent at the tangent of the top head. These test vents are not shown on the plant drawing. It may be difficult to retrieve the small amount of calcine in the nozzle.

Figure 6 shows the attachment make-up of a typical tank nozzle, fill line, and retrieval line connection for one of the bins.

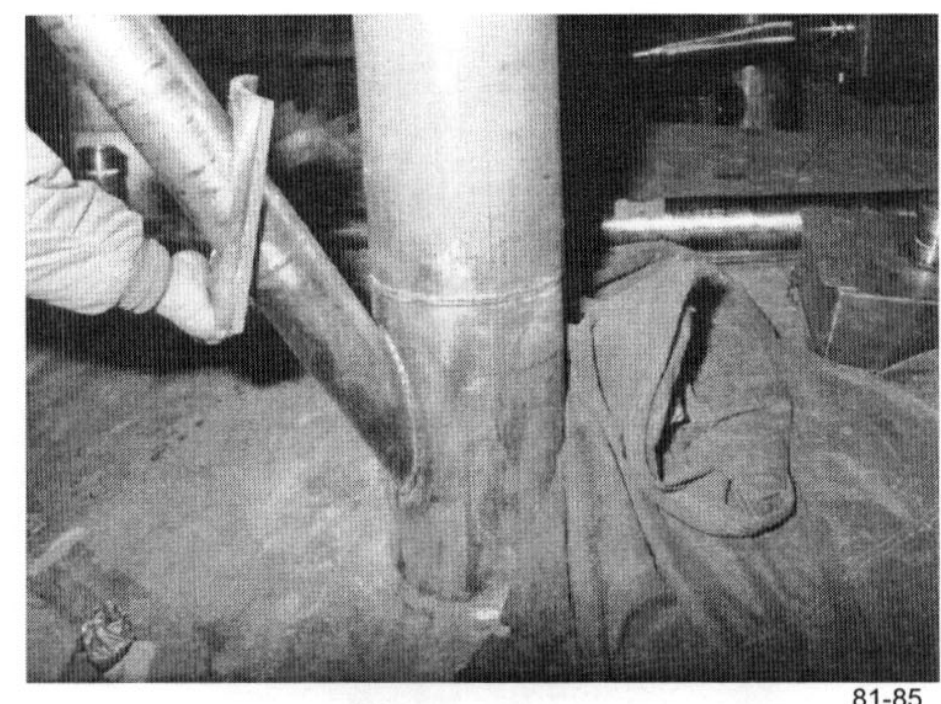

Figure 6. Typical bin connection for Calcined Solids Storage Facility V.

\subsection{Calcined Solids Storage Facility VI}

Calcined Solids Storage Facility VI, also known as Bin Set 6, consists of seven annular bins similar to CSSF V: VES-WS6-154 through -160. Facility design was by EG\&G Idaho of Idaho Falls, Idaho. The bins were fabricated from Type-304L stainless steel by Mason Steel Fabricating Company of Decatur, Illinois.

Each bin is approximately $67.6 \mathrm{ft}$ tall with 13.5 -ft outer and 5 - $\mathrm{ft}$ inner diameters. ${ }^{13}$ The outer wall thickness varies from $1 \mathrm{in}$. at the bottom to $0.375 \mathrm{in}$. at the top, while the inner wall thickness is $0.5625 \mathrm{in}$. throughout. Each bin is fitted with four 8-in., Schedule 40, retrieval access risers, which are attached to 8 -in., Schedule 80, nozzles on the vessels and capped with 8-in., 150-lb, weld-neck flanges. Four risers are $39 \mathrm{ft}$ long and 24 risers are $26 \mathrm{ft}$ long. The usable volume of CSSF VI is approximately $53,200 \mathrm{ft}^{3}$.

Internal obstructions to retrieval operations are two 2-in., Schedule 80, thermocouple wells and associated support hardware located near the annular centerline, and five sets of corrosion coupons hung from separate hangers attached to the outer wall in Bins VES-WS6-156 and VES-WS6-159. Although not 
an internal obstruction, each bin is equipped with two seal-welded, screwed, hydrostatic test vents at the tangent of the top head. The small amount of calcine in the nozzles may be difficult to retrieve.

Figure 7 is a top view of the distribution piping for CSSF VI. The annular bin design is typical of bins in CSSF V and CSSF VI.

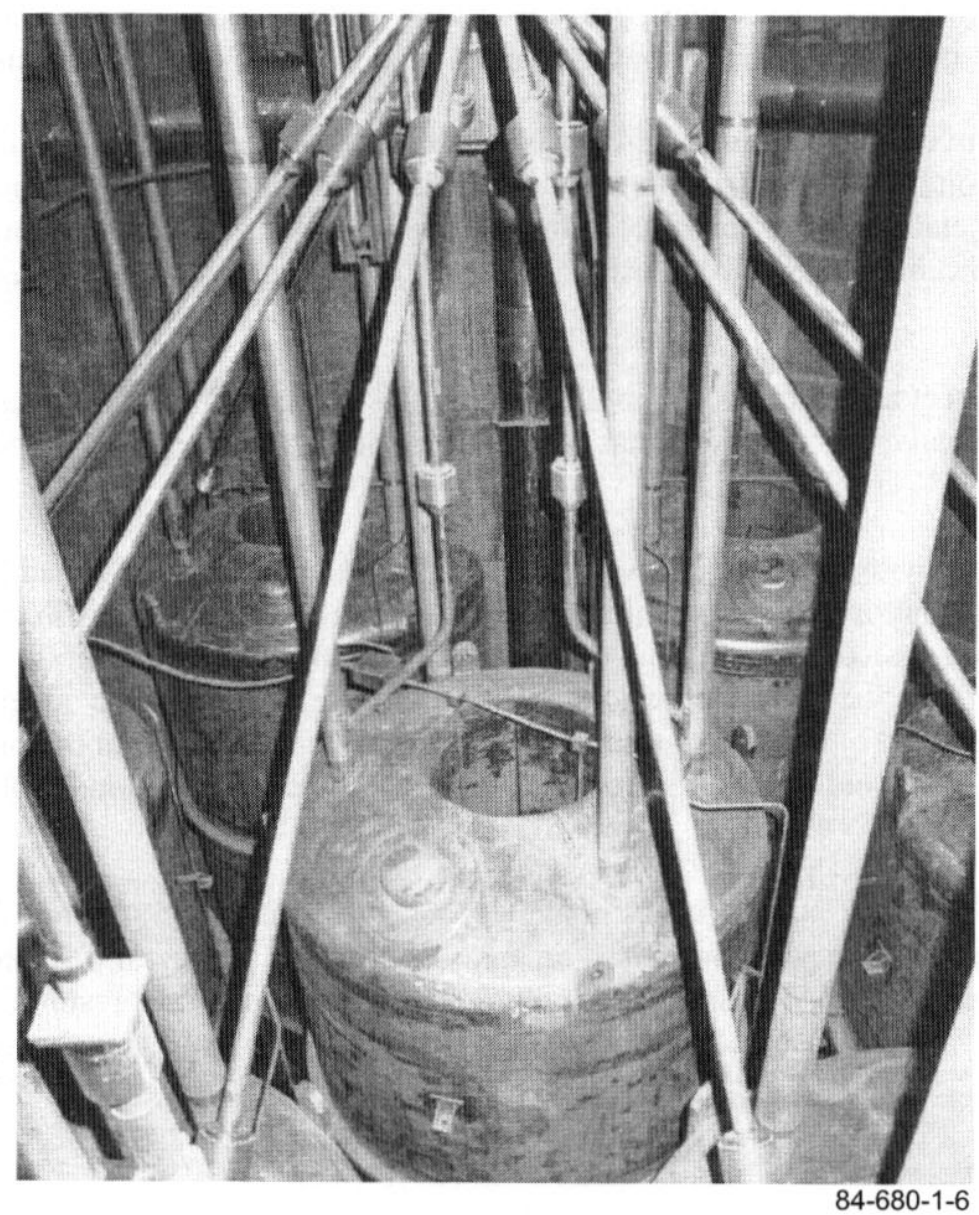

Figure 7. Distribution piping for Calcined Solids Storage Facility VI.

\subsection{Calcined Solids Storage Facility VII}

Calcined Solids Storage Facility VII, also known as Bin Set 7, consists of seven annular bins similar to CSSF VI. Facility design was by EG\&G Idaho of Idaho Falls, Idaho. The bins were fabricated from Type-304L stainless steel by Mitternight Boiler Works of Satsuma, Alabama. Calcined Solids Storage Facility VII currently remains unused. 


\section{INVENTORIES}

This report was produced to fill gaps created by lack of an aceurate cuantitative inventory of the calcined solids stored in the CSSFs. Accurate information is required for detailed evaluation of waste treatment options. Past campaign reporting ${ }^{1+}$ 1" was of a generalized nature. (haracterization reporting ${ }^{20}$ was more specific than the campaign reporting, but did not provide adequate quantitative information. In addition, characterization information about CSSF V and CSSF VI was not completed to the extent it was for CSSF I through VI because of work priorities." Many information sourees were diligently searehed to collect the more detailed information summarized in the appendixes of this report.

Individual bin inventories reported here have been estimated from caleiner liquid feed in formation. Some of the information that is of eurrent interest, particularly the coneentration of long-lived radioactive nuclides and RCRA metals, was not routinely collected at the time of waste generation. To lill in this information gap, the inventories have been estimated based on evaluation ol available information and process knowledge.

Data are not correct to the number of significant figures presented in the various graphs and tables. A review of the statistical error was made that determined that the relative error bound for the calcine inventory is $14 \%$ at a $95 \%$ conlidence level.

Plots of the data found in Revision 1 were presented in an addendum ${ }^{31}$. The addendum report presented a thorough discussion of the inventory estimates for the various species in the ealeine. The report and its associated spreadsheets are found in the addendum folder, $K(P$-EXT-()4-0)(137) Calcine Addendum Report Files, on the CD attached to the jacket. The preparation of the addendum revealed opportunities for refinement' of the source term used to predict the ehemical and radionuclide inventories. The refinements were made and the results are reflected in the revised lables and graphs included in this revision.

Refinement in the SBW source term estimate was recommended' by Swenson. The earlier source term adjusted radionuclide concentrations based on analytical results. Some of the analytical data had been incorrectly incorporated into the souree term. For example the analytical result used for $\mathrm{Np}$ had been reported as a "less than" result. Use of this "less than" result gave high estimates for $\mathrm{Np}$ and its daughters.

g. M. M. Dumas to M. I). Staiger, "NW(F Campaign I1-3 (1093 Portion) Feed Data," MMI)-02-94, Interdepartmental

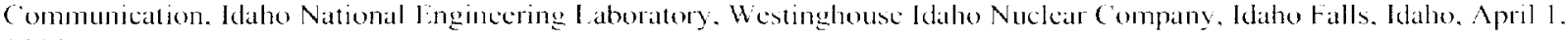
1904.

h. I. R. Thomas to K. F. ('hilds and M. D). Staiger, "Mcasurement Error Analysis for (alcine Verilication Study." IRT-1)]-1)2. Internal Memorandum. Idaho National Fngineering and Fnvironmental l aboratory, Bechtel BWXT Idaho, II C. Idaho Falls. ldaho, March 8.2002 ?.

i. M. C. Swenson to J. I. Pruitt, "Recommendations for Moditications to the Historical Processing Model Isstimates of Radloactivity in INTEC (alcine," MCS-02-04. Interoffice Memorandum. Idaho National Enginecring and Environmental Laboratory, Bechal BWXT Idaho, LIC. Idaho falls, April 19, 2004

j. M. C. Swenson to M. W. Patterson. "Improved Radionuclide Source Term for Sodium-Bcaring Waste." MC S-(1)2-(1)4. Interoffice Memorandum, ldaho National Engineering and linvironmental Laboralory, Bechtel BWXT ldaho, LLC. Idaho Falls. October 26. 2004 . 
The SBW source term was modified and now produces more realistic inventory estimates for calcine produced during SBW processing

\subsection{Chemical}

Chemical information was compiled from original Tank Farm and calciner feed tank sample analysis reports; transcribed analysis information found in reports, letters, and data sheets; process knowledge; and miscellaneous notes. These data were adjusted to account for dilution and chemical adjustment, where appropriate. Where analytical determinations were not made and the constituent was known to be present. estimates were added to more accurately quantify the chemical content of the calcine. (hemical additives, volumes, and concentrations were determined from individual feed batch makeup sheets or were estimated. Table A7 of Appendix A is a spreadsheet that summarizes the best available chemical analysis information.

The total amount of material in individual bins was estimated by summing the volume and concentration of batches fed to the process. The batch masses were distributed between the several bins in the bin set according to the filling sequence. The bin filling sequence was estimated using bin thermocouple data. The bin thermocouples showed a sharp increase in temperature when covered with calcine and thus provided bin level indication. The thermocouple data often varied between weekly and monthly intervals. Thus they did not provide an exact correlation between a given date and a given calcine level. Therefore, the filling sequences and dates were "fine tuned" in an iterative process to produce expected product bulk density values. Chemical amounts are reported in Table Al1. Compound chemistry can be estimated using the method proposed by O'Brien. ${ }^{23}$

Proposed treatments of the calcine could remove cesium and strontium fractions. The quantities of these species have been estimated. The estimated quantities incorporate the assumption that the quantities come from two sources. The first source is the fission product, while the second source is from contaminants ${ }^{k}$ in added chemicals and startup bed material. An average value found in the reference literature ${ }^{24}$ was used to approximate the quantity of strontium and cesium added as startup bed because analyses for the species in the bed material were unavailable. Nonradioactive strontium additions were estimated with additional undocumented information provided by the chemical suppliers. Note that the bulk of the calcium nitrate was manufactured from phosphate sources that are relatively rich in strontium (as high as $2,600 \mathrm{ppm}$ strontium).

The quantity of mercury in the calcined product was adjusted to reflect observed ${ }^{2}$ mercury retention in the calcined product. The assumption was made that $70 \%$ of the mercury in the feed was retained in the product for WCF calcine Campaigns 1,2, and 3. These campaigns were operated with the calciner at $400^{\circ} \mathrm{C}$. Subsequent campaigns operated at $500+{ }^{\circ} \mathrm{C}$. Retention of $1 \%$ was assumed during high-temperature operation. This assumption is supported by the following findings.

k. K. N. Brewer to M. D. Staiger, "Total CS and SK Concentratons in INIEL' Sodium-Bearing and Cakine Wastes," KNB-07-98, Interdepartmental Correspondence, Idaho National Engineering and Environmental Laboratory, Lockheed Martin Idaho Technologies Company, Idaho Fulls, Idaho, June 25, 1998 
- Calcine dissolution resulting from the processing of mercury-containing feed during NWCF Campaign Hot Run 4(H-4) showed approximately 50 -ppm mercury present. ${ }^{1}$ If internal recycle is neglected, this represents $0.5 \%$ retention of the mercury fed.

- $\quad$ A mass balance ${ }^{m}$ for mercury was determined during the fourth NWCF processing campaign. This work was to confirm pilot plant work reported by Newby. ${ }^{25}$ Newby reported that an insignificant fraction of feed stream mercury (approximately $0.5 \%$ ) is present with the fines of dilute zirconium feed. This fraction is even less for the calcined product.

- Newby reported ${ }^{26}$ that $1.7 \%$ of the mercury is found in the sodium-bearing waste fines when aluminum nitrate is used as a calcining process additive, and $0.13 \%$ when dilute zirconium feed is the additive. The retention is substantially lower for bed material.

This report revision includes estimates of several RCRA metals that were not included in previous revisions. The inventories of four additions, arsenic, barium, selenium, and silver, are estimated from fission production. Liquid waste analyses for these constituents were made in the early 1990's, however, the results were typically "less than" laboratory detection limits or inconsistent

Inventories for a fifth addition, lead, are based on a few measurements of lead concentration in the liquid waste during RCRA characterization of Tank Farm wastes in the early 1990s and from a few earlier analyses of sodium-bearing waste. The lead in the waste comes from decontamination solution dissolution of lead shielding material.

Chromium was included in previous report revisions but was modified in this revision to include additional sources of trace quantities of chromium. Some alloys used in the fabrication of aluminum type SNF contained small concentrations of chromium(usually alloy 6061 , nominally $0.2 \mathrm{wt} \% \mathrm{Cr}$ ). while the others (usually alloy 1100 ) did not. The SNF processing information was reviewed to determine the amounts of those specific fuels that were processed. Chromium inventories were adjusted to reflect this additional source of chromium. In addition chromium was sometimes used as an oxidant for improved uranium recovery during solvent extraction. Chromium was added to waste which was known to have contained the oxidant. The addition was based on the aluminum to chromium ratio reported in the solvent extraction flowsheet.

Cadmium and mercury inventories remain essentially unchanged from Revision I because these were used in relatively large amounts during processing and were included in historical waste sample analyses that established the inventory estimates.

Analysis of archived calcine solids showed the presence of sodium, potassium, magnesium, and iron. These species were reported in the earlier report revisions, but the inventories were incomplete because they were based on analytical data from some, but not all, wastes. The previous revision underestimated the amounts of these species because waste streams for which no sample data exited were

1. R. S. Herbst to M. D. Staiger, "Mercury and Chloride Analysis in Calcines Produced in NWCF Campaign H-4," RSH-07-98. Interdepartmental Correspondence, Idaho National Engineering and Environmental Laboratory, Lockheed Martin Idaho Technologies Company, Idaho Falls, Idaho, December 7, 1998.

m. R. E. Schindler to B. H. O’Brien, "Mercury Behavior Durıng NWCF Run H-4 Operation," Interdepartmental Correspondence, Idaho National Engineering and Environmental Laboratory, Lockheed Martin Idaho Technologies Company, Idaho Falls. Idaho, Schi-25-97, Oclober 16, 1997. 
treated as not having any of these components. The waste stream compositions have been adjusted to estimate species for which no analytical data exist based on analytical data of chemically similar wastes.

Carbonate inventories were overstated in the earlier revision because of the conversion of the carbonate ion into gaseous $\mathrm{CO}_{2}$ when blown-over start-up bed is removed by the off-gas scrubbing system and dissolved by the acidic scrub solution. The inventory has been revised to reflect that one half of the original bed charged to the calciner during startup was blown-over to the scrub system, where the carbonate was lost as $\mathrm{CO}_{2}$.

\subsection{Radiochemical}

The radionuclide concentrations were derived from measured inputs and calculated estimates. Limited definitive information was provided on radionuclides at the time of fuel shipment to INTEC. The radioactivity used to calculate the individual feed stream radiochemistry is tabulated in Table A9 of Appendix A. Extensive mixing of the reprocessing waste in the Tank Farm and the unavailability of reactor physics information complicate the reconstruction of inventories and distributions, which is necessary for detailed radionuclide estimation. To overcome these deficiencies, a methodology was conceived in which the fission product inventories for the unanalyzed nuclides were estimated using a recognized computer code, ORIGEN2 - A Revised and Updated Version of the Oak Ridge Isotope Generation and Depletion Code. ${ }^{27}$

Table A10 in Appendix A presents the radionuclide concentrations in the various feed streams processed through the calciners. Table Al0 was generated from a list of nuclides indicated to be of interest for waste classification pursuant to the Federal Register ${ }^{28}$ found in Tables 1 and 2 in 10 Code of Federal Regulations (CFR) 61.55. Tank closure work reported at the Savannah River Site in Aiken. South Carolina, used a similar approach. ${ }^{29}$ The 10 CFR 01.55 tables specify limits for alpha-emitting transuranics with a half-life greater than 5 years and other nuclides with a half-life less than 5 years. Greater than $90 \%$ of the activity of the short-lived lanthanide series nuclides is caused by ${ }^{231} \mathrm{Th}$ and ${ }^{23.3} \mathrm{~Pa}$. Other nuclides were not included because their contributions were nominal. Also excluded from Table Al0 were (1) species that are volatile or combustible during calcination $\left({ }^{3} \mathrm{H}\right.$ and ${ }^{14} \mathrm{C}$ ), because these are not expected to be present in the calcine; (2) activated metal species, because no activated metal was stored with the calcine; and (3) ${ }^{129} I$ because measurements" have confirmed that only a small fraction of the iodine present in the reprocessed fuel is potentially sent to calcined waste storage. The result of implementing these selection criteria is the following listing of nuclides: ${ }^{63} \mathrm{Ni},{ }^{96} \mathrm{Sr},{ }^{(2)} \mathrm{Y},{ }^{(9)} \mathrm{Tc},{ }^{126} \mathrm{Sb}$, ${ }^{126 m} \mathrm{Sb},{ }^{137 \mathrm{~m}} \mathrm{Ba} .{ }^{137} \mathrm{Cs},{ }^{237} \mathrm{Th},{ }^{233} \mathrm{~Pa},{ }^{237} \mathrm{~Np},{ }^{238} \mathrm{Pu},{ }^{239} \mathrm{Pu},{ }^{240} \mathrm{Pu},{ }^{241} \mathrm{Pu}$, and ${ }^{241} \mathrm{Am}$.

The reader can estimate the concentration of any nuclide using D. R. Wenzel's calculation data. These data can be found on the accompanying compact disk (see file Wen R5.xIs). Wenzel estimated that the activities are representative to within a factor of 2.27 (ste p. 54 )

The following relationship was used to gencrate the concentrations given in the table.

Conc. of nuclide $Y_{2016}=$ Est. conc. of ${ }^{137} \mathrm{Cs}_{2010} /$ Wenzel conc. ${ }^{1.37} \mathrm{Cs}_{2016} *$ Wenzel conc. $Y_{2016}$

I1. G. J. McManus to W. G. Robson, "Iodine-129 Mass Balance and Characterization During 1987-1988 FDP and NWCI: Cimpaign," GJM-16-90, Interdepartmental Communication, ldaho National Engineering Laboratory, Westinghouse ldaho Nuclear Company, Liaho Falls, Idaho, August 15, 1990. 
The nuclide concentrations in the various feed streams, shown in Table A10, were estimated based on measured concentration for ${ }^{137} \mathrm{Cs}$ and decayed to 2016 . The assumption was made that the cesium was not preferentially concentrated in plant waste and that ratios in the waste are the same as those in the parent fuel prior to reprocessing. This assumption is a first approximation and is not entirely accurate because it is in turn based on the assumption that the radionuclides were stored together in a single volume of waste. However, during periods of plant operation. raffinate streams were stored separately. The term raffinate, defined as the waste from refinement processes, was used at INTEC to refer to the waste products from the refinement of waste involved in first-, second-, and third-cycle reprocessing of spent nuclear fuel. Historically, the raffinates were separated into two categories: high-level waste from first-cycle extraction and sodium-bearing waste from second-and third-cycle extraction, which were blended with other types of waste. Typically, second and third cycle extraction waste contained higher transuranic activity relative to Cs-137 than first cycle waste. The radioactivity models were adjusted to account for this partitioning based upon sample data of the various waste streams.

This revision corrects for a period of time when neptunium was recovered at the plant during the mid 1960 's to early 1970's. The source term of the earlier revision used a neptunium depleted raffinate when generating the source term. A significant fraction of the raffinates were not neptunium depleted therefore the $\mathrm{Np}$ inventory was under estimated in those wastes. The new source term corrected this error. When analytical results were unavailable for raffinates that experienced $\mathrm{Np}$ recovery adjustments were made to correct for the lower expected inventory.

Stream \#86 had an additional complication because it was a mixture of SBW and HLW and was labeled as SBW in Revision 1. Blending HLW and SBW wastes produced a waste stream with a cesium concentration of stream $\sim 240 \mathrm{mCi} / \mathrm{l}$. Normal SBW is $\sim 50 \mathrm{mCi} / \mathrm{l}$ and $\mathrm{HLW}$ is closer to $\sim 800 \mathrm{mCi} / \mathrm{l}$. Thus stream \#86 had a much higher Cs-137 activity than typical SBW. This coupled with relatively high transuranic and uranium to Cs-137 ratios for SBW caused the model to predict higher than expected uranium and transuranic inventories. This was observable as a "hump" in the Th-231, Pa-233, Np-237, Pu isotopes, and Am-24l plots in the CSSF VI inventories in the addendum report. The predicted inventories in Stream \#86 were improved by building its inventory with appropriate portions of HLW and SBW. These changes produced a more reasonable inventory estimate and eliminated the "humps" in the CSSF VI plots.

\subsection{Filling Summaries}

Tables A 1 through A6 in Appendix A summarize the operation of the WCF and NWCF on a batch-by-batch basis. However, batch information for WCF Campaign 1 and most of Campaign 2 could not be found and was estimated by taking the amount of waste calcined each month and dividing it into a reasonable number of batches based upon calcination history and process knowledge. Tables AII and A 12 in Appendix A were prepared based on these batch data. These tables summarize production estimates on bin filling and represent, in a simplified manner, the expected distribution of chemical and radiochemical species in each bin. Horizon breaks (the interval between thermocouples) were estintated based on temperature measurements (physical measurement of bin filling was done infrequently) during filling operations. Tables A14 and A15 in Appendix A provide estimated storage facility totals for principal radioactive and elemental species.

The filling chronology ${ }^{\circ}$ for the various bins had been prepared for only a few bins. Graphs of the filling history (see Figures B25 through B30 in Appendix B) for each bin were prepared for this report

o. J. W. Garner to L. J. Weber. "Temperatures in Present Solids Storage Facilities," JWG-94-64A, Internal Correspondence, National Reactor Testing Station, Phillips Petroleum Co., Atomic Division, Idaho Falls, Idaho, December 22, 1964. 
from available temperature measurement data. Because temperature readings were tiken infrequently, the plots are not completely accurate. For example, the thermocouple may have been covered shortly before or after data collection. Operational interruptions were taken into account where appropriate. These graphs were used to estimate solids production rates in an attempt to quantify the concentration of chemical and radiochemical species listed in Tables A11 and Al2.

\subsubsection{Calcined Solids Storage Facility I}

Calcined Solids Storage Facility I was used to collect calcine during cold testing of the WCF, which took place between February 1961 and November 1962. Before radioactive startup, the nonradioactive testing calcine was removed. During the first WCF processing campaign, which ran from late November 1963 to October $1964,{ }^{14}$ the bins were filled with nonradioactive alumina startup bed and radioactive aluminia calcine.

Based in the information in Appendix A and summarized in Table 1, approximate volumes of calcine sent to storage in CSSF I are $200 \mathrm{ft}^{3}$ of cold alumina calcine from calciner startup and 7,600 $\mathrm{ft}^{3}$ of radioactive alumina calcine. The facility contains about $3.0 \times 10^{6} \mathrm{Ci}$ of activity decayed to January 1 , 2016. The highest temperature recorded in the CSSF I was 435 F, in Bin VES-WCS-115-3-B in November 1964. The estimated chemical composition for the solids is documented in Table A11. A breakdown by major radionuclides is documented in Table A 12.

\subsubsection{Calcined Solids Storage Facility II}

Calcined Solids Storage Facility II was placed in radioactive service in April 1966 with the startup of WCF Campaign 2. The complete production output of calcine from WCF Campaigns 2, 3, and $4^{15,16,17}$ are stored in CSSF II, which was filled in February 1972, approximately during the middle of WCF Campaign $5 .^{18}$

The facility was filled with alumina and zirconia calcines. Based in the information in Appendix A and summarized in Table 1, approximate volumes of calcine sent to storage are $900 \mathrm{ft}^{3}$ of dolomite and cold alumina, $10,000 \mathrm{ft}^{3}$ of hot alumina calcine, and $19,100 \mathrm{ft}^{3}$ of hot zirconia calcine. It contains about $6.4 \times 10^{\circ} \mathrm{Ci}$ of activity decayed to January 1,2016 . The highest temperature recorded in the CSSF II was $1,284^{\circ} \mathrm{F}$, in Bin VES-WCS-136-3 in August 1969. The estimated chemical composition for the solids is documented in Table All. A breakdown by major radionuclides is documented in Table A12.

The design of CSSF II included provisions for calcined product segregation. Collection of calcine in either Bins VES-WCS-136-1 or -2 could be achieved by use of a diverter. Separate storage of zirconia and alumina calcines was planned, but when the diverter system was activated in WCF Campaign 2. separation of the two calcines was not achieved because the feed pipe to the diverter became plugged. The plug was cleared after the campaign.

The solids in two of the CSSF II bins were sampled in 1978. Samples of alumina-type calcine stored in Bin VES-WCS-136-3 and zirconia-type calcine stored in Bin VES-WCS-136-7 were obtained by inserting a long probe into the full bins. The probe retrieved material at multiple depths throughout each bin. This sampling and analysis effort ${ }^{31}$ confirmed that stored calcine had not agglomerated or consolidated into a large irretrievable mass.

The intention was to sequentially fill the bins from overflow lines located at increasing elevations on the distributor pipe in the following order: Bins VES-WCS-136-4, -3, -5, -7, and -6. For the most part, this was realized. However, the central distributor pipe allowed small amounts of solids to accumulate in 
other bins (see filling curves in Figure B26 in Appendix B). Consequently, the exact composition of the calcine stored in the lowest areas of the bins is uncertain.

\subsubsection{Calcined Solids Storage Facility III}

Calcined Solids Storage Facility III was placed in radioactive service in February 1972, which was approximately in the middle of WCF Campaign 5. It was filled in March 1981 with the completion of WCF Campaign 9. ${ }^{19}$

The facility was filled with alumina, stainless steel, zirconia, and zirconia-sodium blend calcines produced during the fifth, sixth, seventh, eight, and ninth WCF processing campaigns. Based in the information in Appendix $A$ and summarized in Table 1, approximate volumes of calcine sent to storage are $3,500 \mathrm{ft}^{3}$ of cold alumina, $1,100 \mathrm{ft}^{3}$ of dolomite and fluorapatite from calciner startup, 2,300 $\mathrm{ft}^{3}$ of hot alumina, 26,050 $\mathrm{ft}^{3}$ of zirconia, $6,500 \mathrm{ft}^{3}$ of zirconia-sodium blend, and $50 \mathrm{ft}^{3}$ of calcine from stainlesssteel waste processing (blended with zirconium waste). The CSSF contains about $7.4 \times 10^{6} \mathrm{Ci}$ of activity decayed to 1 January 2016. The highest temperature recorded in CSSF III was $640^{\circ} \mathrm{F}$, in Bin VES-WCS140-3 in June 1968. The estimated chemical composition for the solids is documented in Table A11. A breakdown by major radionuclides is documented in Table A 12.

The design of CSSF III included provisions for calcine segregation. Collection of calcine in Bin VES-WCS-140-1 could be achieved by use of a diverter. The other bins were intended to fill concurrently. However, data indicate some preferential filling occurring, which could be attributed to plugging of the fill line (see filling curves in Figure B27 of Appendix B).

\subsubsection{Calcined Solids Storage Facility IV}

Calcined Solids Storage Facility IV was used to collect calcine from July 1981 to June 1982 , during the nonradioactive testing of the NWCF. Before radioactive startup, a commercial contractor removed the nonradioactive calcine. ${ }^{\Gamma}$ The bins were filled with hot calcine between August 1982 and July 1983 (during the tirst half of NWCF Campaign 1). After May 30, 1983, the diverter ${ }^{22}$ in the solids distribution outlet was used to divert solids to Bin VES-WS4-143. Indications were that the normal fill pipe leading from the distributor to the bin had become restricted (see filling curves in Figure B28 in Appendix B). All bins in the CSSF were filled by July 15, 1983, after which solids storage operations were switched to CSSF V.

The facility was primarily filled with zirconia and zirconia-sodium blend calcines. Based in the information in Appendix $A$ and summarized in Table 1, approximate volumes of calcine sent to storage are $600 \mathrm{ft}^{3}$ of cold alumina and dolomite from calciner startup, $100 \mathrm{ft}^{3}$ of hot alumina-zirconia blend, $5,100 \mathrm{ft}^{3}$ of zirconia, and $11,300 \mathrm{ft}^{3}$ of zirconia-sodium blend calcines. The CSSF contains about $4.1 \times 10^{6} \mathrm{Ci}$ of activity decayed to January 1,2016 . The highest temperature recorded in CSSF IV was $601^{\circ} \mathrm{F}$, in VES-WS4-142 in October 1983. The estimated chemical composition for the solids is documented in Table Al1. The estimated composition of the major radionuclides is documented in Table A12.

p. C. L. Fawcett, retired Westinghouse Idaho Nuclear Company employee, phone conversation with M. D. Staiger, December 10, 2002 . 


\subsubsection{Calcined Solids Storage Facility V}

Calcined Solids Storage Facility $V$ was placed in radioactive service in July 1983 , midway through NWCF Campaign 1. It filled in January 1992, about mid-way through NWCF Carnpaign 3 (see filling curves in Figure B29 in Appendix B).

The facility was filled with alumina, zirconia, zirconia-sodium blend, zirconia-sodium-ROVER blend, and sodium-ROVER blend calcines. Based in the information in Appendix A and summarized in Table 1 , approximate calcine volumes are $2,800 \mathrm{ft}^{3}$ of cold alumina and dolomite from calciner startup, $50 \mathrm{ft}^{3}$ of pilot plant calciner product, and $32,800 \mathrm{ft}^{3}$ of hot calcine from processing of aluminum-, zirconium-, ROVER-, and sodium-blended feed stocks. The facility contains about $9.0 \times 10^{\circ} \mathrm{Ci}$ of activity decayed to January 1,2016 . The highest temperature recorded in CSSF V was $239^{\circ} \mathrm{F}$, in Bin VES-WS5-140 in July 1988. The estimated chemical composition for the solids is documented in Table A11. A breakdown by major radionuclides is documented in Table A12.

\subsubsection{Calcined Solids Storage Facility VI}

Calcined Solids Storage Facility VI was placed in radioactive service in January of 1993, about midway through NWCF Campaign 3 . It was $48 \%$ full at the time this report was prepared. Reported waste volumes include waste processed during NWCF Campaign 4 through May 2000.

The facility was partially filled with alumina, zirconia-alumina-sodium blend, and nonradioactive aluminum nitrate-sodium-bearing waste blend calcines produced during the third and fourth NWCF processing campaigns. Based in the information in Appendix $\mathrm{A}$ and summarized in Table 1 , approximate volumes of calcine are $100 \mathrm{ft}^{3}$ of pilot plant calciner product, $1,400 \mathrm{ft}^{3}$ of cold alumina and dolomite from calciner startup, and $24,100 \mathrm{ft}^{3}$ of hot calcine. The CSSF contains about $2.4 \times 10^{6} \mathrm{Ci}$ of activity decayed to January 1,2016 from calcine generated through May 2000. The highest temperature recorded in CSSF VI was $153^{\circ} \mathrm{F}$, in Bin VES-WS6-154 in August 1994. The estimated chemical composition for the solids is documented in Table All. A breakdown by major radionuclides is documented in Table Al2. 


\section{REFERENCES}

1. D. A. Knecht, et al., "Historical Fuel Reprocessing and HLW Management in Idaho," Radw'aste Magazine, Vol. 4, No.3, May 1997, pp. 35-45.

2. L. T. Lakey and J. R. Bower, ed., ICPP Waste Calcining Facility Safety Analysis Report, IDO-14620, December 1963, pp. vi58-vi64.

3. Lockheed Martin Technologies Company, Laho Chemical Processing Plant Safety Analysis Report, Part II, "Facility-Specific Safety Analysis," Section 5.1, "New Waste Calcining Facility," INEL-94/(022. Idaho National Engineering and Environmental Laboratory, Idaho Falls, Idaho, April 1997.

4. C. L. Bendixsen, Safety Review Report for the In-Bed Combustion System for the Waste Calcining Facility, CI-1 175, National Reactor Testing Station, Idaho Nuclear Corporation, Idaho Falls, Idaho, March 1970.

5. G. E. Lohse, Safety Analysis Report For ICPP High-Level Solid Radioactive Waste Storage Facilities, ICP-1005, National Reactor Testing Station. Allied Chemical Corporation, Idaho Falls, Idaho. January 1972.

6. D. L. Griffith, CSSF / Storage Vault Inspection Report, INEEL/EXT-97-01376, Idaho National Engineering Laboratory, Lockheed Martin Technologies Company, Idaho Falls, Idaho, June 1998.

7. C. L. Bendixsen and G.E. Lohse, Storage Facilities for Radioactive Calcined Waste Solids at the Idaho Chemical Processing Plant, IN-1155, National Reactor Testing Station, Idaho Nuclear Corporation, Idaho Falls. Idaho, July 1968.

8. A. G. Westra, et al., Sampling of Stored High-Level Radioactive Calcined Waste at ICPP, ICP-1 186. Idaho National Engineering Laboratory, Allied Chemical Corporation, Idaho Falls, Idaho, March 1979, p 9.

9. D. P. Wright and C. L. Bendixsen, Design Criteria for ICPP Third Solids Storage Facility for Radioactive Calcine Waste Solids, CI-1 129, National Reactor Testing Station, Idaho Nuclear Corporation, Idaho Falls, Idaho, November 1968, p. 12.

10. J. R. Bower, ed., Chemical Technology Branch Annual Report Fiscal Year 1969. IN-1314, National Reactor Testing Station, Idaho Nuclear Corporation, Idaho Falls, Idaho, October 1969, p. 54.

11. R. E. Schindler, Revised Design Criteria for ICPP Fourth Calcined Solids Storage Facility, ACI-165, National Reactor Testing Station, Allied Chemical Corporation, Idaho Falls, Idaho, October 1975.

12. K. N. Cummings and R. E. Schindter, Project Design Criteria for the ICPF Fifth Calcined Solids Storage Facility, ACI-220, National Reactor Testing Station. Allied Chemical Corporation, Idaho Falls, Idaho, Augusi 1977.

13. R. F. Mozes, Project Design Criteria for the ICPP Sixth Calcined Solids Storage Facility, ENI-101, Idaho National Engineering Laboratory, Exxon Nuclear Idaho Company, Idaho Falls, Idaho, November 1979. 
14. R. E. Commander, et al., Operation of the Waste Calcining Facility with Highly Radioactive Aqueous Waste, Report of the First Processing Campaign, IDO-14662, National Reactor Testing Station, Phillips Petroleum Co., Idaho Falls, Idaho, June 1966.

15. G. E. Lohse and M. P. Hales, Second Processing Campaign in the Waste Calcining Facility, IN-1344, National Reactor Testing Station, Idaho Nuclear Corporation, Idaho Falls, Idaho, March 1970

16. C. L. Bendixsen, G. E. Lohse, and M. P. Hales, The Third Processing Campaign in the Waste Calcining Facility, IN-1474, National Reactor Testing Station, Idaho Nuclear Corporation, Idaho Falls, Idaho, May 1971

17. J. A. Weilang, G. E. Lohse and M. P. Hales, The Fourth Processing Campaign in the Waste Calcining Facility, FY-1971, ICP-1004, National Reactor Testing Station, Allied Chemical Corporation, Idaho Falls, Idaho, March 1972.

18. J. A. Weilang and W. A. Freeby, The Fifth Processing Campaign in the Waste Calcining Facility, FY-1972, ICP-1021, National Reactor Testing Station, Allied Chemical Corporation, Idaho Falls, Idaho, June 1973.

19. K. F. Childs, R. I. Donovan, and M. C. Swenson, The Ninth Processing Campaign in the Waste Calcining Facility, ENICO-1100, Idaho National Engineering Laboratory, Exxon Nuclear Idaho Company, Idaho Falls, Idaho, April 1982.

20. R. A. Kirkbride, Inventory of Calcined Waste Stored at the ICPP as of September 1979, ENICO-1044, Idaho National Engineering Laboratory, Exxon Nuclear Idaho Company, Idaho Falls, Idaho, September 1980.

21. J. R. Berreth, Inventories and Properties of ICPP Calcined High-Level Waste, WINCO-1050, Idaho National Engineering Laboratory, Westinghouse Idaho Nuclear Corporation, Idaho Falls, Idaho, February 1988.

22. D. L. Penwell, Calcined Waste Inventory for Calcined Storage Facility IV, WINCO-1162, Idaho National Engineering Laboratory, Westinghouse Idaho Nuclear Corporation, Idaho Falls, Idaho, October 1993.

23. B. H. O'Brien, Estimation of Alkali Metal Mole Percent and Weight of Calcined Solids for ICPP Calcine, INEL-95/0184, Idaho National Engineering Laboratory, Lockheed Martin Technologies Company, Idaho Falls, Idaho, March 1995.

24. P. B. Goetz, ed., The New Encyclopedia Britannica, Vol. 15, p. 940, 1990.

25. B. J. Newby, Calcination of Dilute Zirconium Waste, ENICO-1042, Idaho National Engineering Laboratory, Exxon Nuclear Idaho Company, Idaho Falls, Idaho, November 1980.

26. B. J. Newby, Calcination of Sodium-Bearing Waste using Non-Radioactive Additives, ENICO-1043, Idaho National Engineering Laboratory, Exxon Nuclear Idaho Company, Idaho Falls, Idaho, October 1980. 
27. D. R. Wenzel, Relative Inventories of Reactor-Produced Species in INTEC Waste Types, ldaho National Engineering and Environmental Laboratory, Engineering Design File EDF-CRPD-()()1, Rev. 2, Idaho National Engineering and Environmental Laboratory, Bechtel BWXT Idaho. LLC. Idaho Falls, Idaho, January 2005 to be issued.

28. 10 CFR 61, "Licensing Requirements for Land Disposal of Radioactive Wastes," Code of Federal Regulatioms, Office of the: Federal Register. January 1992.

29. T. B. Caldwell. et al., "Closing High-Level-Waste Tanks at the Savannah River Site," Radwaste Magazine, Vol. 5, No.2, March 1998, pp. 19-26.

30. B. A. Staples, G. S. Pomiak, and E. L. Wade. Properties of Radioactive Calcine Retrieved from the Second Calcined Solids Storage Facility at ICPP. ICP-1189, Idaho National Engineering Laboratory, Allied Chemical Corporation, Idaho Falls, Idaho, March 1979.

31. M. D. Staiger, M. C. Swenson, and T. R. Thomas, Addendum to the Calcined Waste Storage at the Idaho Nuclear Technology and Engineering Center, IC P/EXT-(04-(00370), Idaho National Engineering Laboratory, Bechtel BWXT Idaho, LLC, May $20(04$

32. A. G. Croff, ORIGEN2 - A Revised and Updated Version of the Oak Ridge Isotope Generation and Depletion Code, ORNL-5621. Oak Ridge National Laboratory, Oak Ridge, Tennessee, 1980 
Appendix A

Pertinent Data and Summaries of Data Manipulations 


\section{Appendix A}

\section{Data and Data Manipulation Summaries Contents}

\section{Tables}

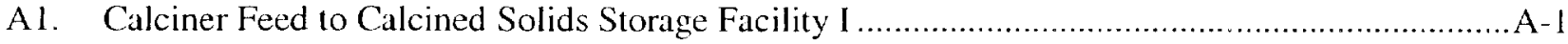

A2. Calciner Feed to Calcined Solids Storage Facility II ..........................................................

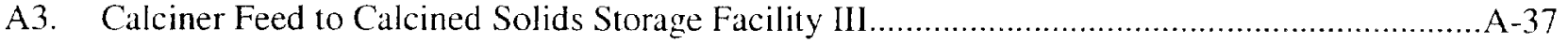

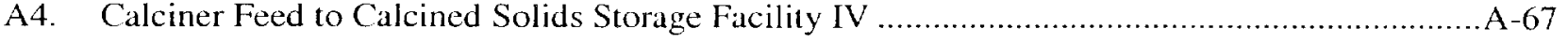

A5. Calciner Feed to Calcined Solids Storage Facility V ...........................................................

A6. Calciner Feed to Calcined Solids Storage Facility VI ........................................................

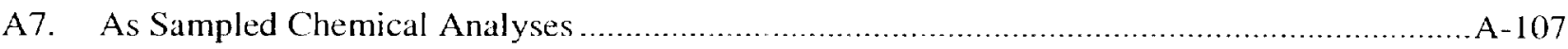

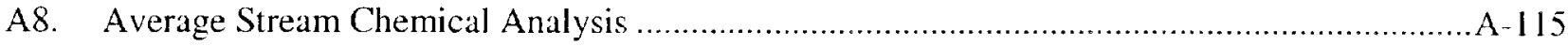

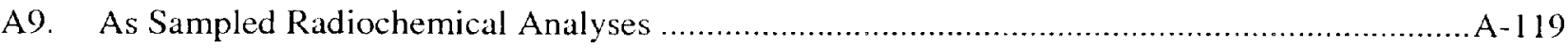

A10. Average Stream Radiochemical Analysis Estimate @ Jan 2016 ...........................................A-127

A11. Calcine Storage Stratification vs. Chemistry

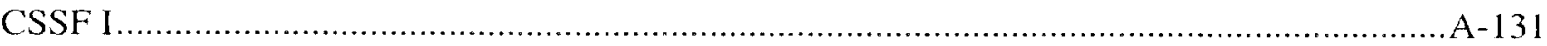

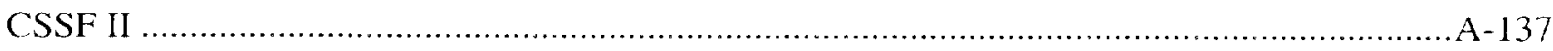

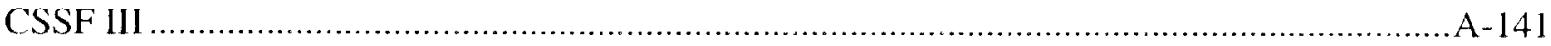

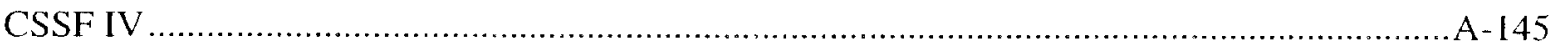

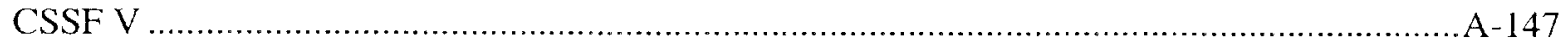

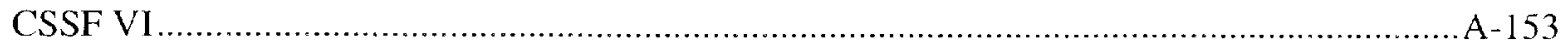

A 12. Calcine Storage Stratification vs. Radiochemistry

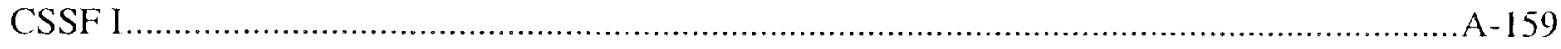

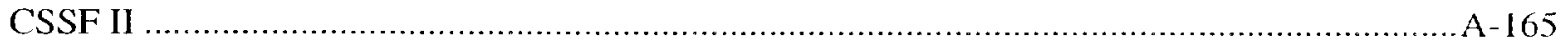

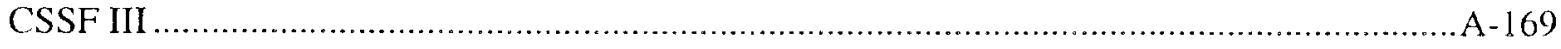

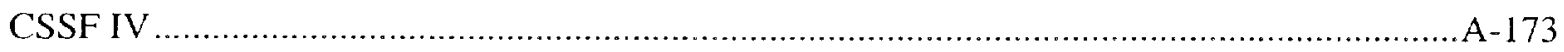


CSSF $V$

A- 175

CSSF VI

A-181

A 13. Estimated Radiochemical Inventory for Selected Years.

A-189

A 14. Distribution Radiochemical Inventory at @ 2016

A- 191

A15. Distribution of Chemical Inventory

A16 Estimated RCRA Inventory A-195

A-17 Stored Calcine Bulk Density Estimate A- 197

A 18. INTEC Historical Reprocessing A-199 
A-iv 
Table A I. Calciner Feed to Calcined Solids Storage Facility I.

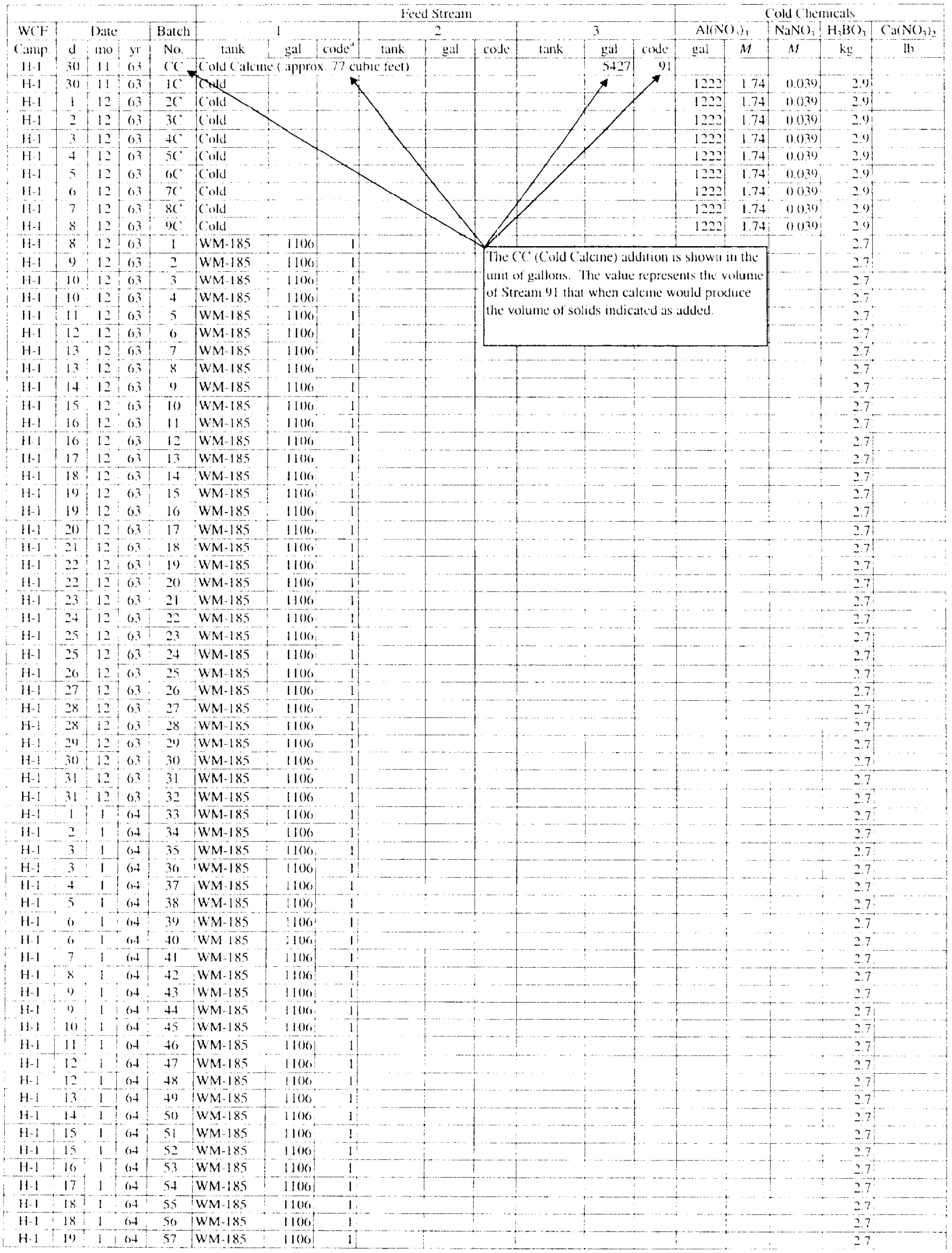


Table A 1. Calciner Feed to Calcined Solids Storage Facility I. (continued)

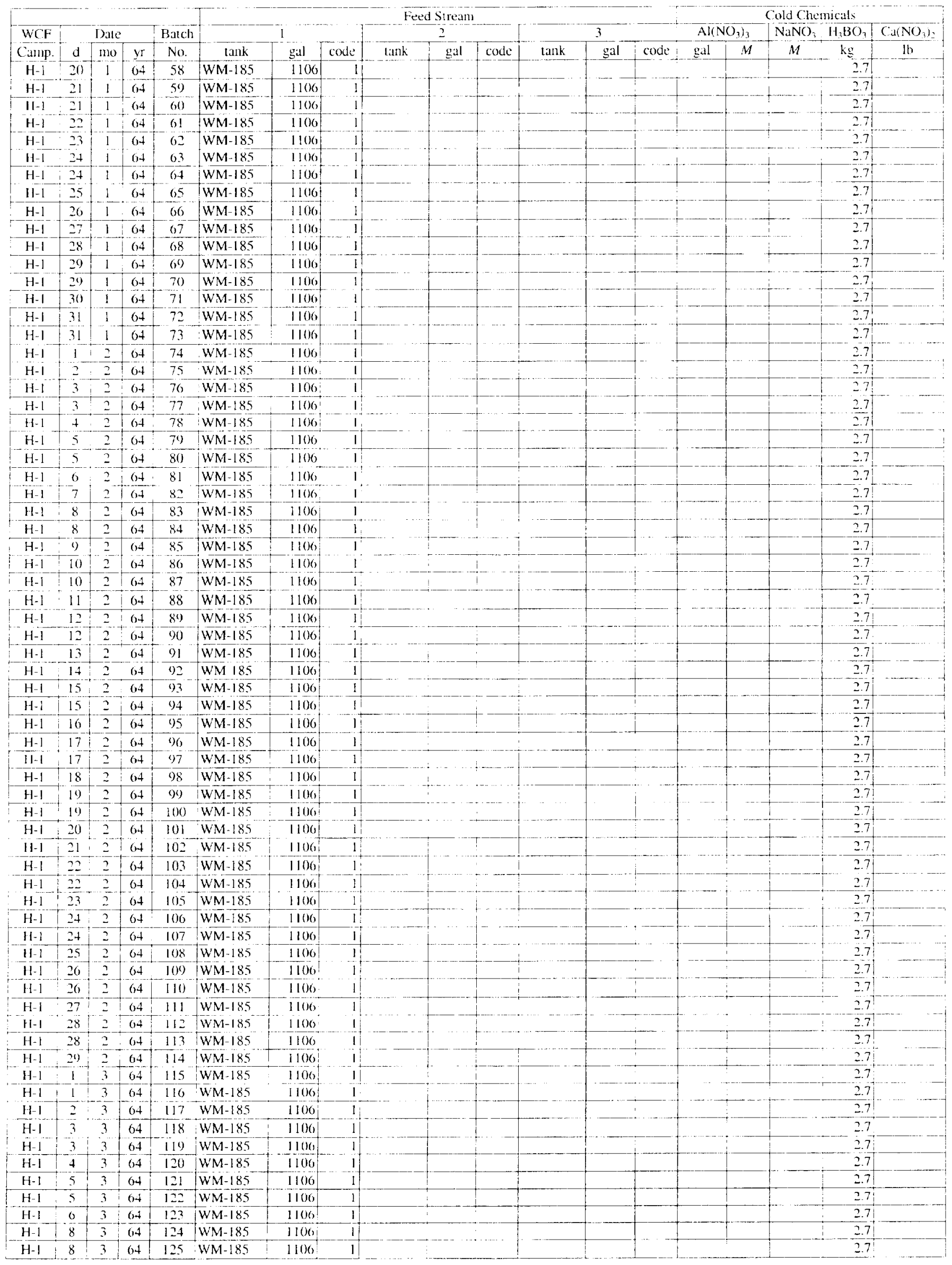


Table A1. Calciner Feed to Calcined Solids Storage Facility I. (continued)

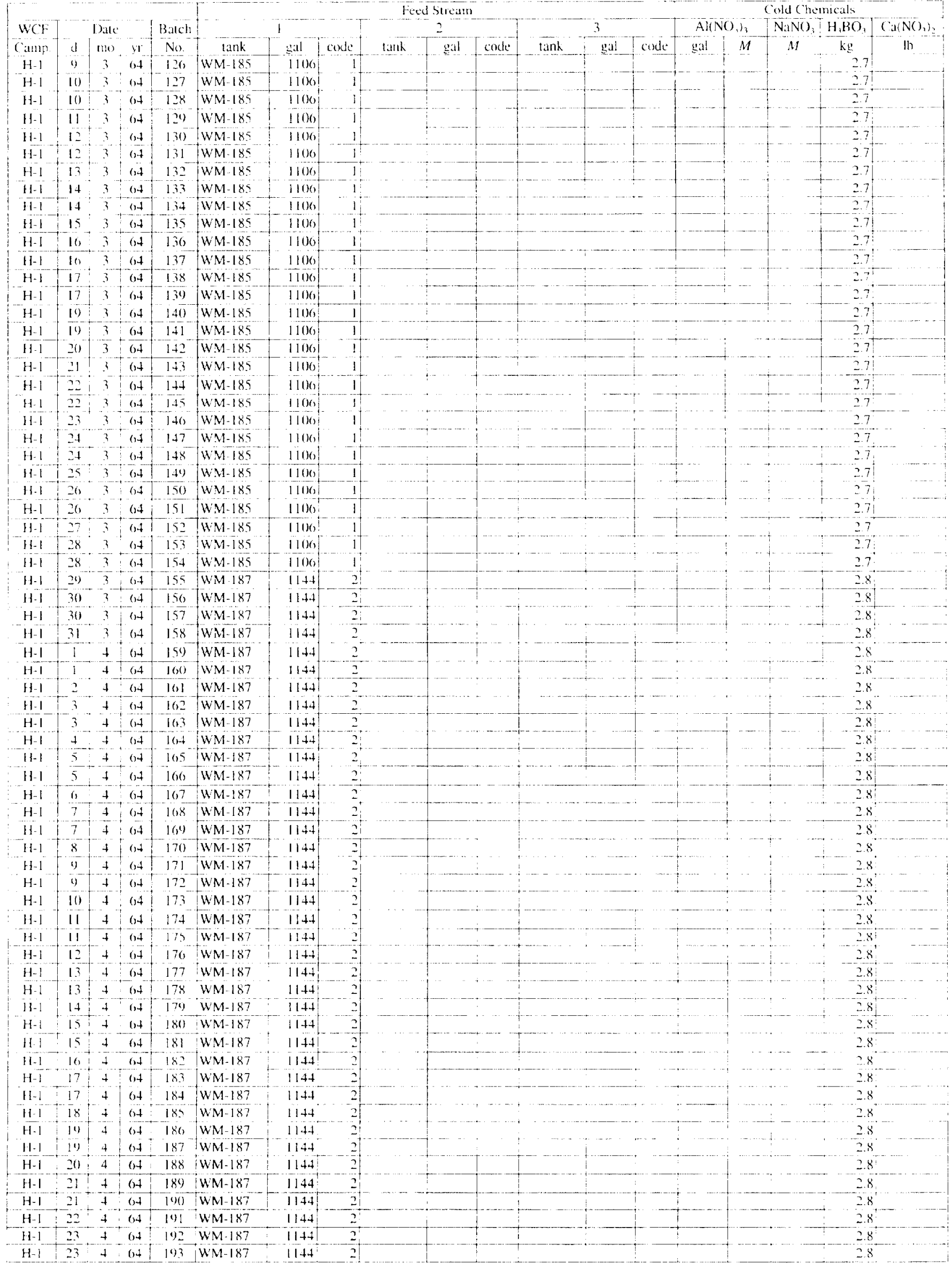


Table A 1. Calciner Feed to Calcined Solids Storage Facility I. (continued)

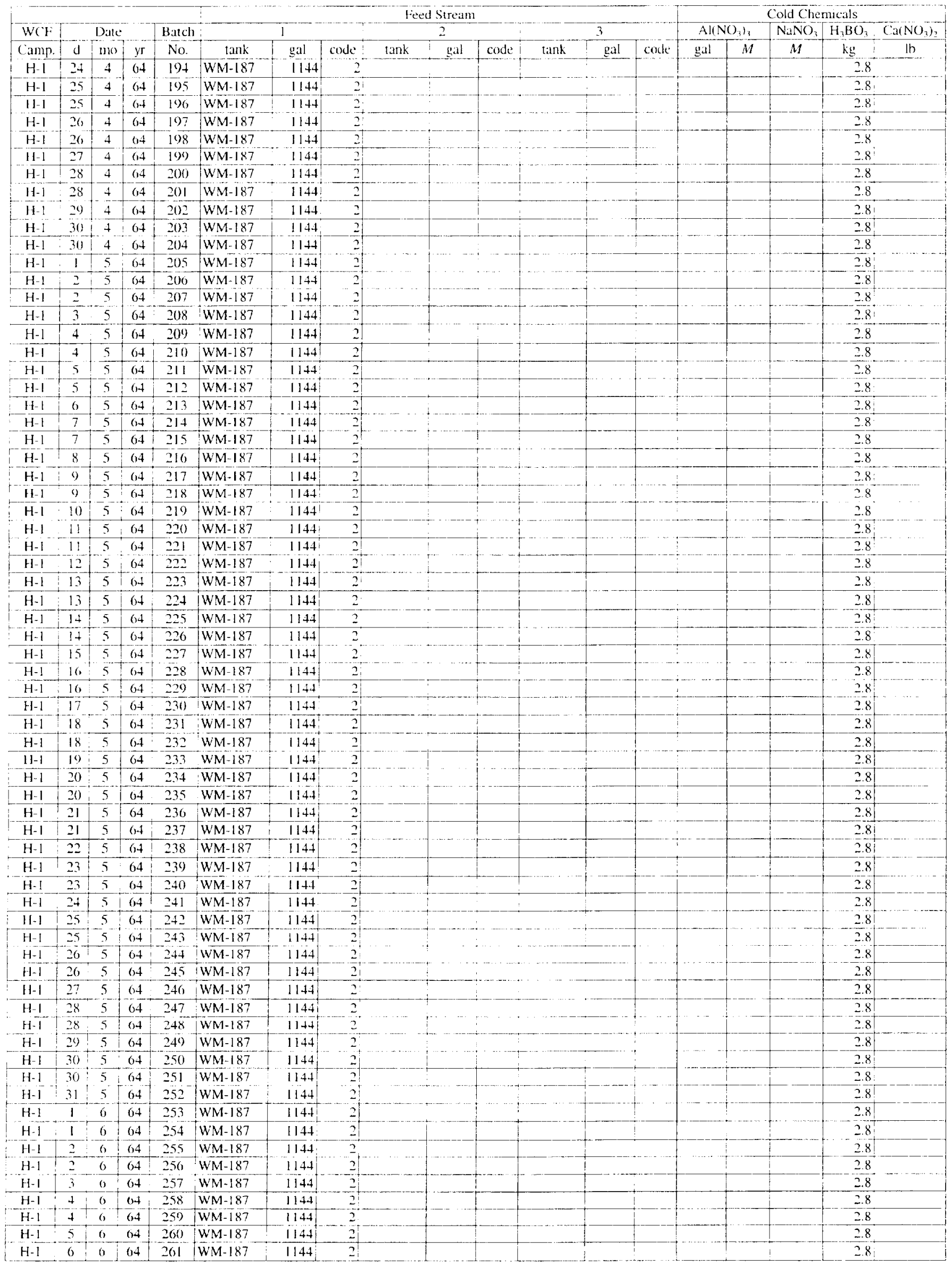


Table A 1. Calciner Feed to Calcined Solids Storage Facility I. (continued)

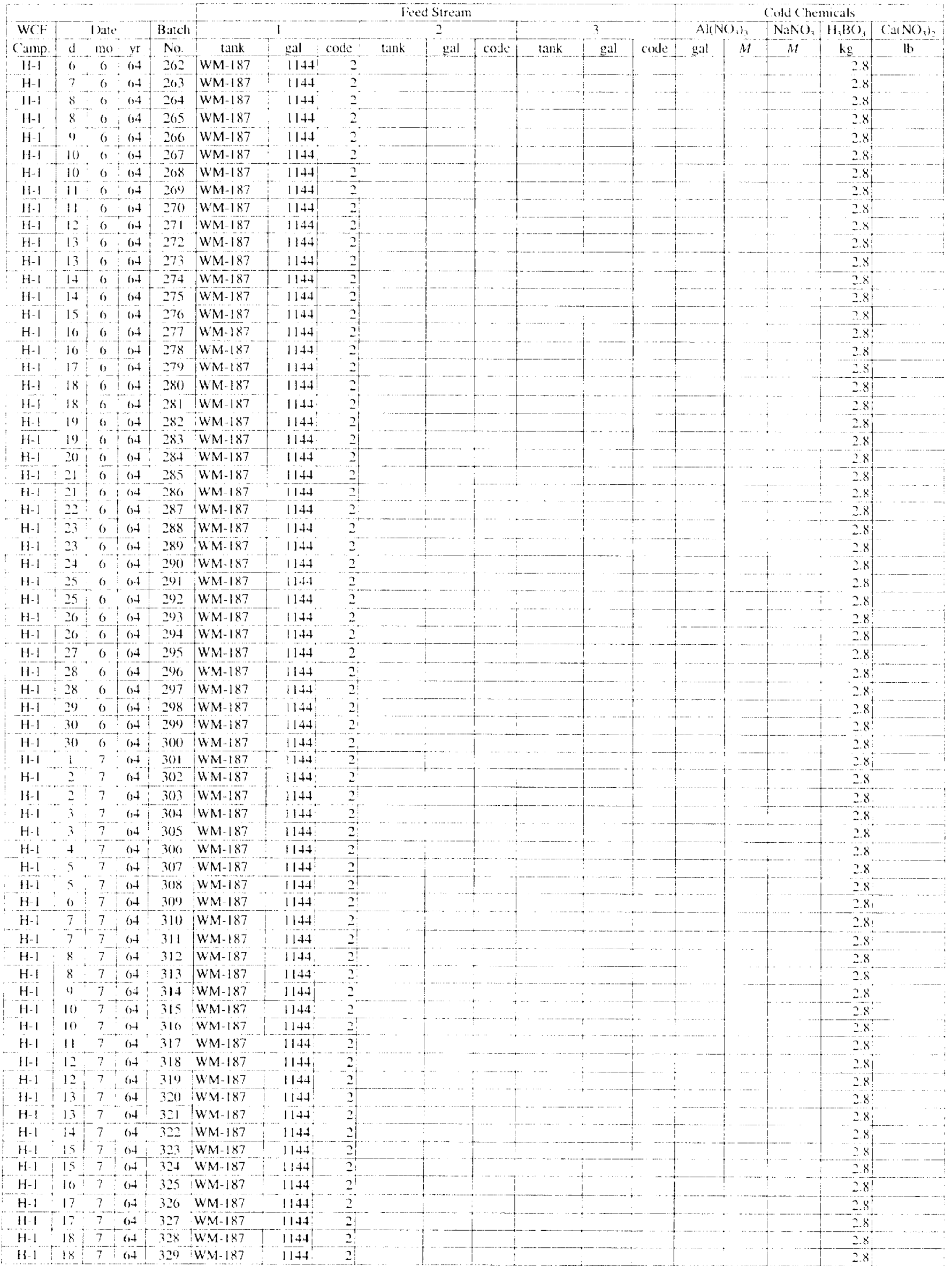


Table A 1. Calciner Feed to Calcined Solids Storage Facility I. (continued)

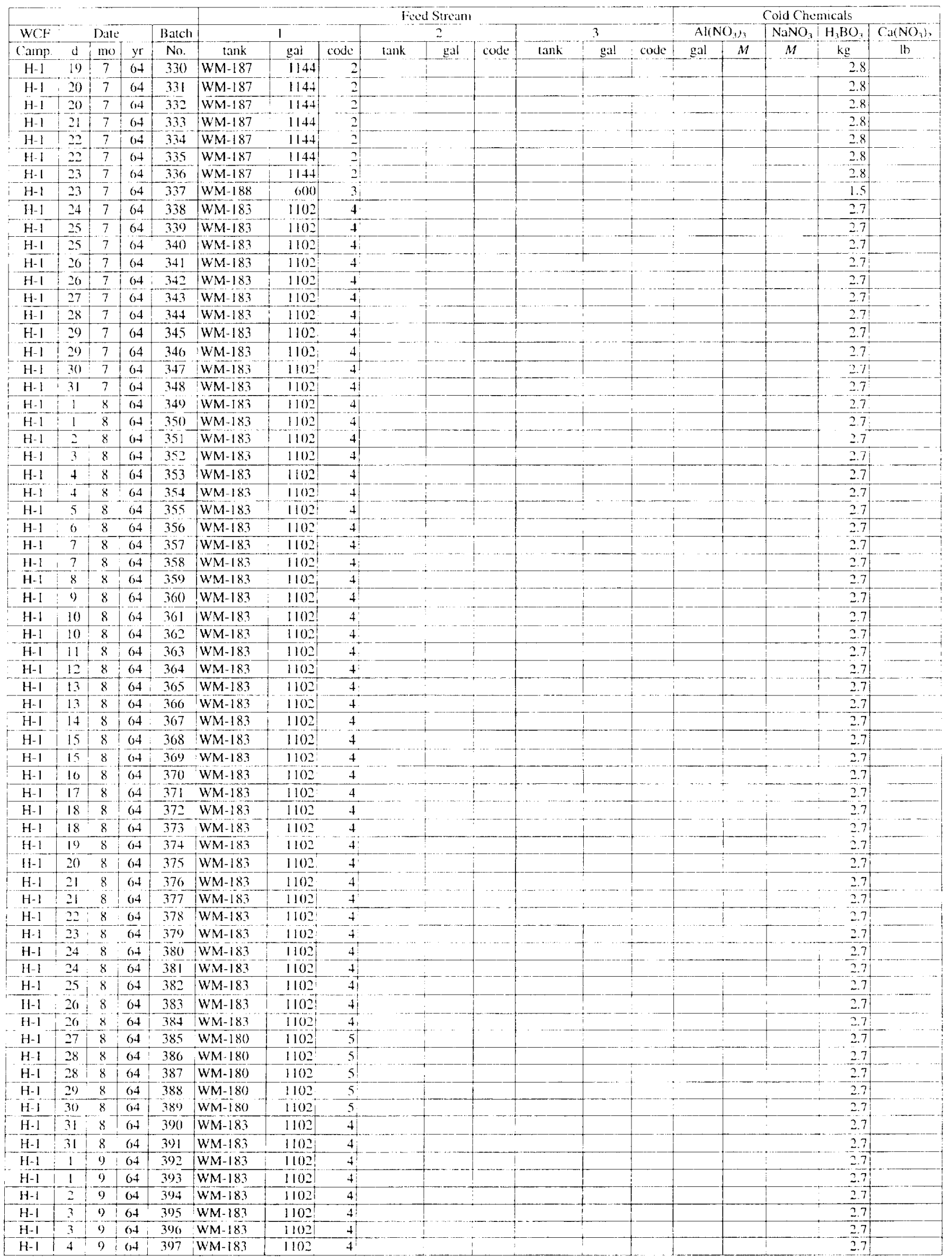


Table A 1. Calciner Feed to Calcined Solids Storage Facility I. (continued)

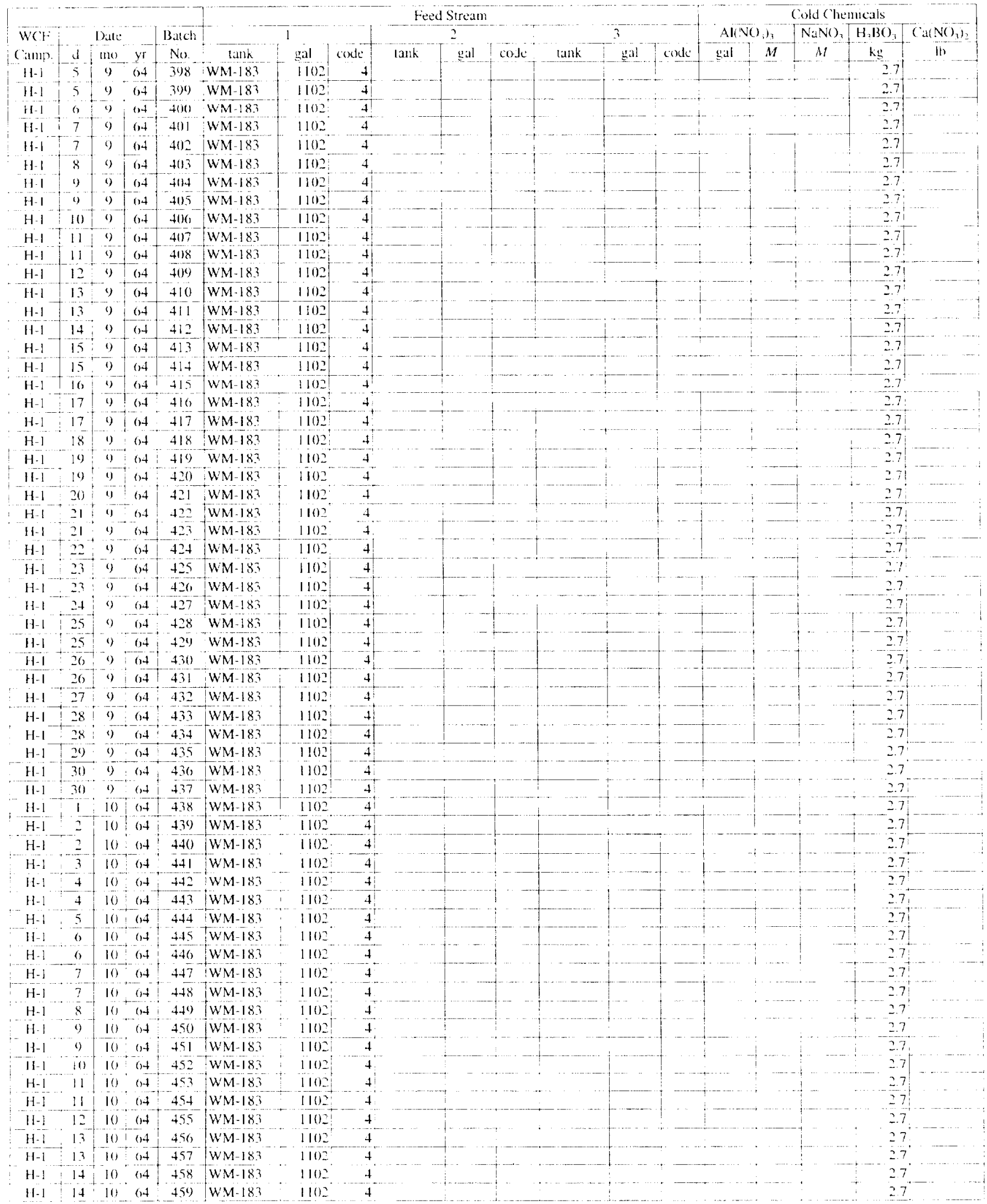


page intentionally blank 
Table A2. Calciner Feed to Calcined Solids Storage Facility II.

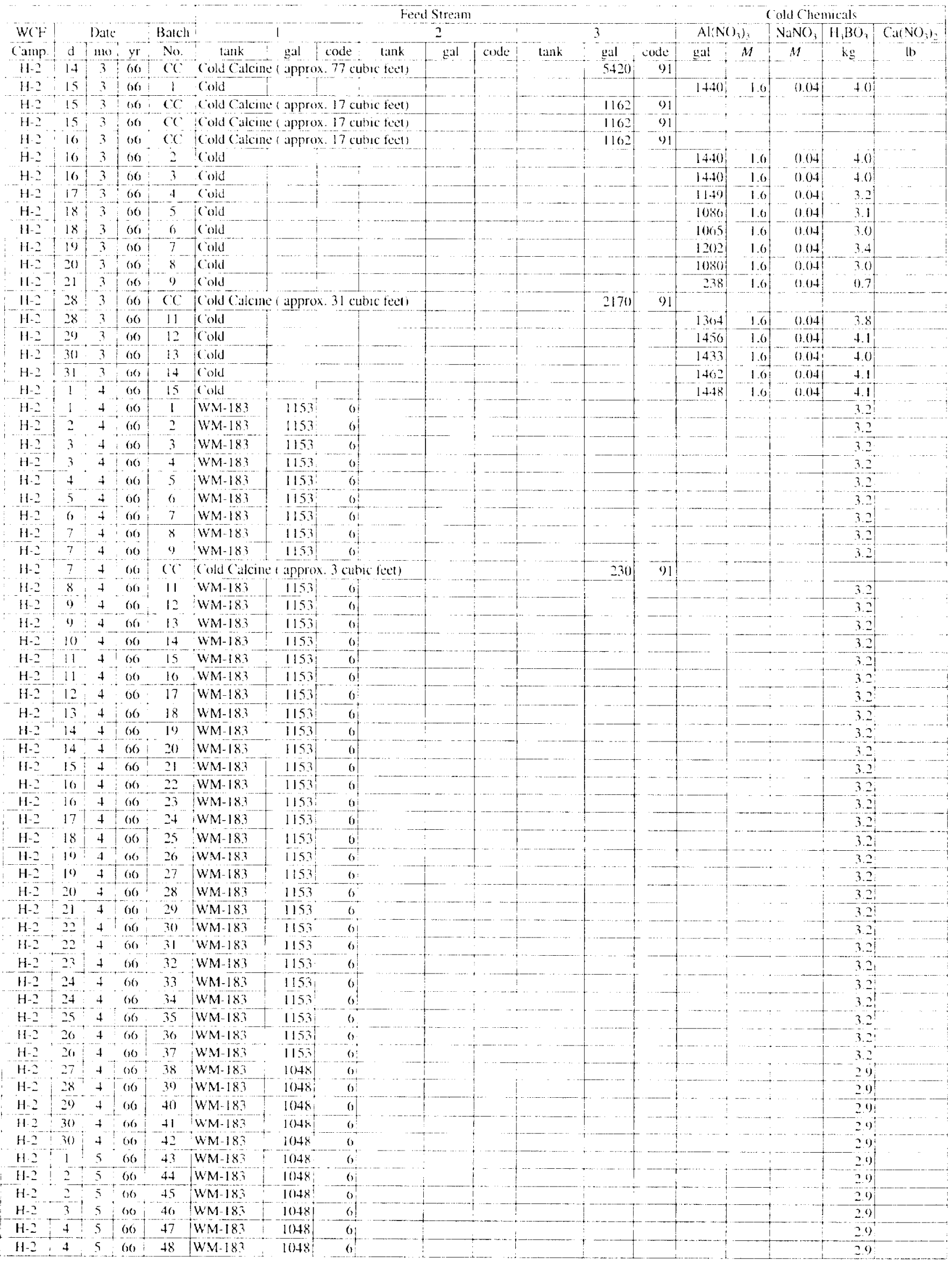


Table A2. Calciner Feed to Calcined Solids Storage Facility Il. (continued)

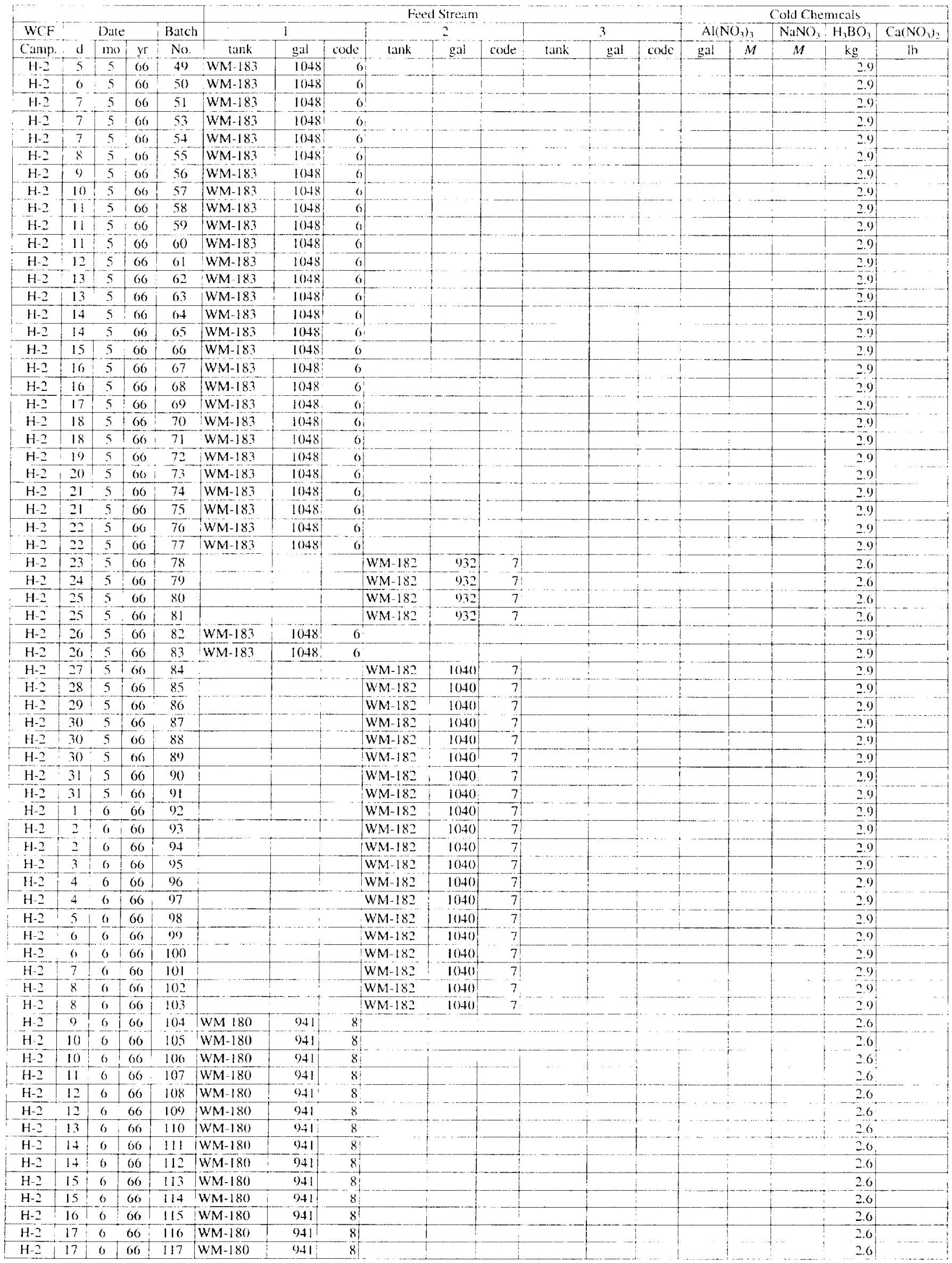


Table A2. Calciner Feed to Calcined Solids Storage Facility II. (continued)

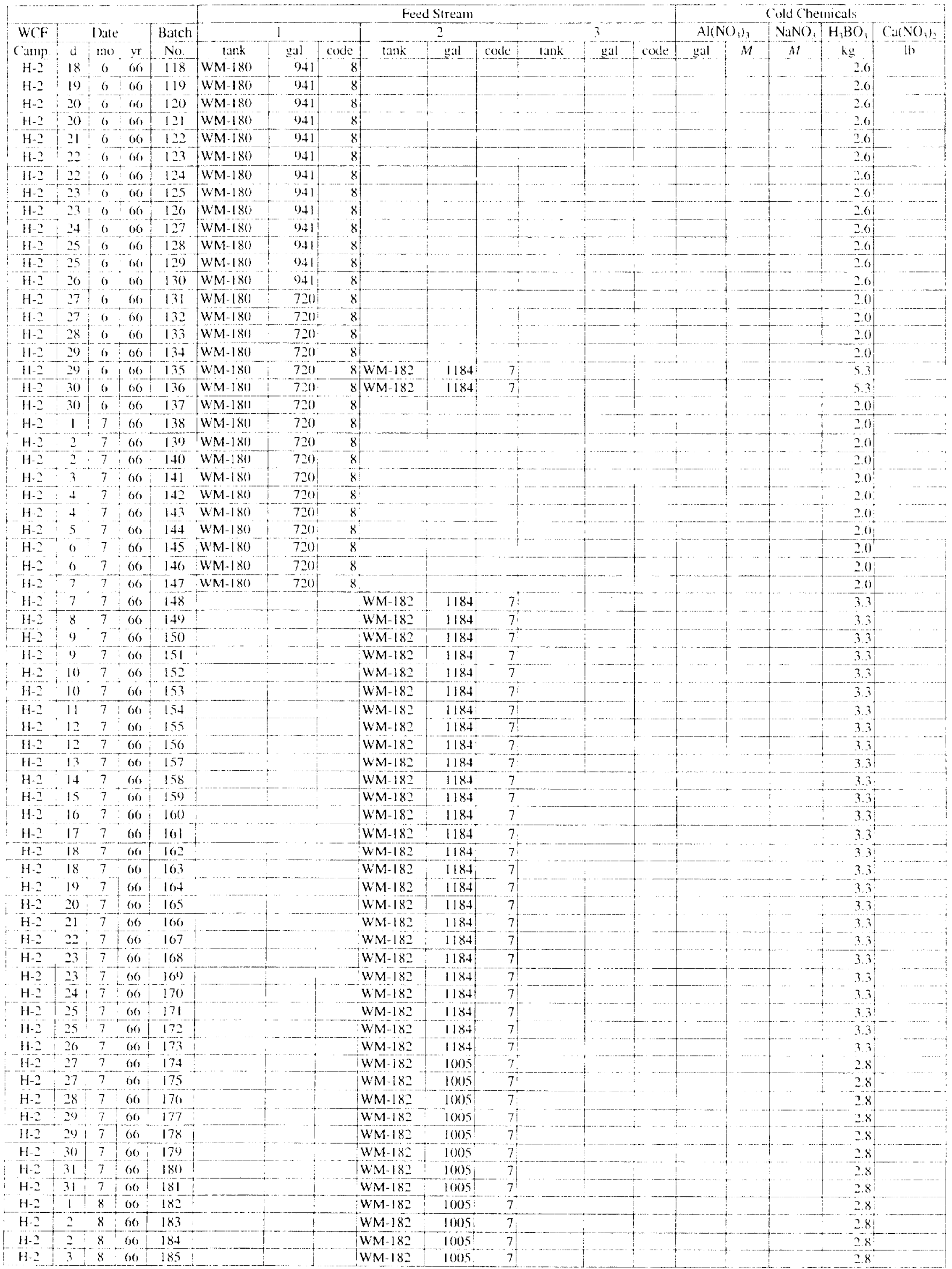


Table A2. Calciner Feed to Calcined Solids Storage Facility II. (continued)

\begin{tabular}{|c|c|c|c|c|c|c|c|c|c|c|c|c|c|c|c|c|c|c|}
\hline \multicolumn{14}{|c|}{ 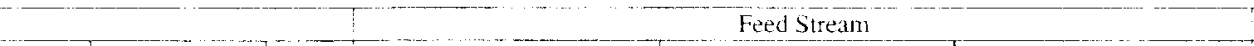 } & \multicolumn{5}{|c|}{ Cold Chemicals } \\
\hline WCF & \multicolumn{3}{|c|}{ Date } & \multirow{2}{*}{$\frac{\text { Batch }}{\text { No. }}$} & & l & & & 2 & & & 3 & & $\mathrm{~A})(\mathrm{NC}$ & & $\mathrm{NaNO}_{3}$ & $\mathrm{H}_{7} \overline{\mathrm{BO}_{3}}$ & $\mathrm{Ca}\left(\mathrm{NO}_{3}\right)_{2}$ \\
\hline Camp. & $\mathrm{d}$ & mo & $\mathrm{yr}$ & & tank & gal & code & $\operatorname{tank}$ & gal & code & tank & gal & cade & gal & $M$ & $\bar{M}$ & $\mathrm{~kg}$ & $\mathrm{Ib}$ \\
\hline$H-2$ & 4 & 8 & 66 & 180 & & & & WM-182 & 1005 & 7 & & & & & & & 2.8 & \\
\hline $\mathrm{H}-2$ & 4 & 8 & 60 & 187 & & & & WM-182 & 1005 & 7 & & & & & & & 28 & \\
\hline $\mathrm{H}-2$ & 5 & 8 & 60 & 188 & & & & WM-182 & 1005 & 7 & & & & & & & 2.8 & \\
\hline $\mathrm{H}-2$ & 6 & 8 & 00 & 189 & & & & WM-182 & 1005 & 7 & & & & & & & 2.8 & \\
\hline $\mathrm{H}-2$ & 7 & 8 & 60 & 190 & & & & $W M-182$ & $1005:$ & 7 & & & & & & & 28 & \\
\hline $\mathrm{H} 2$ & 7 & 8 & 60 & 191 & & & & WM-182 & $1005^{5}$ & 7 & & & & & & & 28 & \\
\hline $\mathrm{H}-2$ & 8 & 8 & 66 & 192 & & & & WM-182 & $1005:$ & 7 & & & & & & & 2.8 & \\
\hline $\mathrm{H} 2$ & 8 & 8 & 60 & 193 & & & & WM 182 & 1005 & 7 & & & & & & & 2.8 & \\
\hline $\mathrm{H}-2$ & 10 & 8 & 66 & $C$ & Cold Calci & tapprox. & x. 8 cub & bic leet) & & & & 540 & 91 & & & & & \\
\hline $\mathrm{H}-2$ & 13 & 8 & 66 & 194 & & & & WM-182] & 1005 & 7 & & & & & & & 2.8 & \\
\hline $\mathrm{H}-2$ & 14 & 8 & 60 & 195 & & & & WM-182 & 1005 & $7]$ & & & & & & & 2.8 & \\
\hline $11-2$ & 14 & 8 & 60 & 190 & & & & $W M-182$ & 1005 & 7 & & & & & & & 2.8 & \\
\hline $\mathrm{H}-\mathrm{I}$ & 1.5 & 8 & 66 & 197 & & & & $W M-182$ & 1005 & 7 & & & & & & & 28 & \\
\hline $\mathrm{H}-2$ & 16 & 8 & 66 & 198 & & & & WM-182 & 10053 & 7 & & & & & & & 28 & \\
\hline $\mathrm{H}-2$ & 16 & 8 & 66 & 199 & & & & WM-182 & $1005]^{-}$ & 7 & & & & & & & 2.8 & \\
\hline$H-2$ & 17 & 8 & 60 & 200 & & & & $W M-182$ & 1005 & 7 & & & & & & & 2.8 & \\
\hline $\mathrm{H}-2$ & 18 & 8 & 66 & 201 & WM-180 & $148^{\circ}$ & 8 & & & 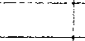 & & & & & & & 4.2 & \\
\hline $\mathrm{H}-2$ & 18 & 8 & 60 & 202 & & & & WM-182 & 1005 & 7 & & & & & & & 2.8 & \\
\hline $\mathrm{H}-2$ & 19 & 8 & 60 & 203 & WM-180 & 1489 & 8 & & & +4 & & & & & & & 4.2 & \\
\hline $\mathrm{H}-2$ & 20 & 8 & 66 & 204 & & & & WM-182 & 1005 & $7 !$ & & & & & & & 28 & \\
\hline $\mathrm{H}-2$ & 20 & 8 & 66 & 205 & WM-180 & 1489 & 8 & & & 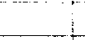 & & & & & & & 4.2 & \\
\hline $\mathrm{H}-\mathrm{z}$ & 21 & 8 & 60 & 200 & & & & $W M-182$ & 1005 & $7 !$ & & & & & & & $288^{\circ}$ & \\
\hline H-2 & 22 & 8 & 60 & 207 & $W M-180$ & 1489 & 8 & & & & & & & & & & 4.2 & \\
\hline $\mathrm{H}-2$ & 22 & 8 & 60 & 208 & & & & WM-182 & 1005 & 7 & & & & & & & 2.8 & \\
\hline $\mathrm{H}-2$ & 23 & 8 & 66 & 209 & WM-180 & 1489 & 8 & & t & $=$ & & & & & & & 4.2 & \\
\hline $\mathrm{H}-2$ & 24 & 8 & 60 & 210 & & & & WM-182 & 1005 & 7 & & & & & & & 28 & \\
\hline $\mathrm{H}-2$ & 24 & 8 & 60 & 211 & WM-180 & 1489 & 8. & & & 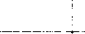 & & & & & & & 4.2 & \\
\hline $\mathrm{H}-2$ & 25 & 8 & 60 & 212 & & & & $W M-182$ & 1005 & 7 & & & & & & & 28 & \\
\hline $\mathrm{H} 2$ & 26 & 8 & 60 & 213 & WM-180 & 1489 & 8 & & & 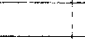 & & & & & & & 4.21 & \\
\hline $\mathrm{H}-2$ & 27 & 8 & 66 & 214 & & & & WM-182 & 1109 & 7 & & & & & & & 3.11 & \\
\hline $\mathrm{H}-2$ & 27 & 8 & 66 & 215 & WM-180 & 808 & 8 & & & & & & & & & & $2.3+$ & \\
\hline $\mathrm{H} \cdot 2$ & 28 & 8 & 66 & 216 & & & & WM-182 & 1109 & $?$ & & & & & & & 3.1 & \\
\hline $\mathrm{H}-2$ & 29 & 8 & 60 & 217 & WM-180 & 808 & 8 & & & $i$ & & & & & & & 2.3 & \\
\hline $\mathrm{H}-2$ & 30 & 8 & 66 & 218 & & & & WM-182 & 1109 & $7 \vdots$ & & & & & & & 3.1 & \\
\hline $\mathrm{H}-2$ & 30 & 8 & 66 & 219 & $W M-180$ & 808 & 8 & & & & & & & & & & 2.3 & \\
\hline $\mathrm{H}-2$ & $3 i$ & 8 & 66 & 220 & & & & WM-182 & 1109 & 7 & & & & & & & 3.1 & \\
\hline $\mathrm{H}-2$ & 1 & 9 & 66 & 221 & $W M-180$ & 808 & 8 & & & & & & & & & & 23 & \\
\hline $\mathrm{H}-2$ & 1 & 9 & 66 & 222 & & & & WM-182 & 1109 & 7 & & & & & & & 3.11 & \\
\hline $\mathrm{H}-2$ & 2 & 9 & 60 & 223 & $W M-180$ & 808 & 8 & & & & & & & & & & 2.31 & \\
\hline $\mathrm{H}-2$ & 3 & 9 & 60 & 224 & & & & WM-182 & 1100 & 7 & & & & & & & 3.1 & \\
\hline $\mathrm{H}-2$ & 3 & 9 & 60 & 225 & WM-180 & 808 & 8 & & & & & & & & & & 2.3 & \\
\hline $\mathrm{H}-2$ & 4 & 9 & 66 & 226 & & & & WM-182 & 1109 & 7 & & & & & & & $3.1 !$ & \\
\hline $\mathrm{H}-2$ & 5 & 9 & 60 & 227 & $W M-180$ & 808 & 8 & & & & & & & & & & $2.3 !$ & \\
\hline $\mathrm{H}-2$ & 5 & 9 & 66 & 228 & & & & $W M-182$ & 1100 & 7 & & & & & & & 3.1 & \\
\hline $\mathrm{H}_{2}$ & 6 & 9 & 66 & 229 & WM 180 & 808 & 8 & & & & & & & & & & 2.3 & \\
\hline $\mathrm{H}-2$ & $\overline{7}$ & 9 & 66 & 2.30 & & & & WM-182 & 1109 & 7 & & & & & & & 3.1 & \\
\hline $\mathrm{H}-2$ & 7 & 9 & 66 & 231 & WM-180 & 808 & 8 & & & & & & & & & & $2.3 !$ & \\
\hline $\mathrm{H}-2$ & 8 & 9 & 66 & $23 \overline{2}$ & & & & $W M-182$ & 1100 & 7 & & & & & & & 3.1 & \\
\hline $\mathrm{H}-\mathrm{Z}$ & 9 & 9 & 60 & 233 & WM-180 & 808 & 8 & & & & & & & & & & 2.3 & \\
\hline $\mathrm{H}-2$ & 9 & 9 & 60 & 234 & WM-180 & 808 & 8 & & & +1 & & & & & & & 2.3 & \\
\hline $\mathrm{H}-2$ & 10 & 9 & 66 & 235 & & & & WM-182 & 1109 & 7 & & & & & & & 31 & \\
\hline $\mathrm{H}-2$ & 11 & ) & 60 & 236 & WM-180 & $808^{1}$ & 8 & & & & & & & & & & 2.3 & \\
\hline $\mathrm{H}=2$ & 12 & 9 & 60 & $C C$ & Cold Calci & I approx. & 2 cubi & sic feet) & & & & 150 & 91 & & & & $\ldots .$. & \\
\hline $\mathrm{H}-2$ & 8 & 11 & 60 & $\mathrm{CC}$ & Cold Calci & (approx. & $.77 \mathrm{cul}$ & abic feet) & & & & 5420 & 91 & & & & & \\
\hline $11-2$ & $\overline{9}$ & 11 & 60 & Cold & Cold & & & & & & & & & 1805 & 1.6 & 0.04 & 5.1 & \\
\hline $\mathrm{H}-2$ & 10 & 11 & 60 & Cold & Coll & & & & & & & & & 1805 & 1.6 & 004 & 5.1 & \\
\hline $\mathrm{H}-2$ & 11 & 11 & 66 & Cold & Cold & & & & & & & & & 1805 & $1.6:$ & 0.04 & 5.11 & \\
\hline $\mathrm{H}-2$ & 12 & 11 & 60 & Cold & Cold & & & & & ! & & & & $1805^{\circ}$ & $1.6 i$ & 0.04 & 5.1 & \\
\hline $\mathrm{H}-2$ & 13 & 11 & 66 & Cold & Cold & & & & & & & & & 1805 & 1.6 & 0.04 & 5.1 & \\
\hline 11.2 & 14 & 11 & 66 & 238 & & & & $W M-182$ & 1101 & 7 & & & & & & & 3.1 & \\
\hline $11-2$ & 15 & 11 & 60 & 239 & & & & WM-182 & 1101 & 7 & & & & & & & 3.1 & \\
\hline $\mathrm{H} 2$ & 10 & 11 & 60 & 240 & $W M-180$ & $936 !$ & 8 & & & & & & & & & & 2.6 & \\
\hline $\mathrm{H}-2$ & 17 & 11 & 66 & 241 & & & & WM-182 & 1101 & 7 & & & & & & & $3.1^{1}$ & \\
\hline $\mathrm{H}-2$ & 17 & 11 & 60 & 242 & WM- 180 & 936 & 8 & & & & & & & & & & 26 & \\
\hline $11-2$ & 18 & 11 & 60 & 243 & WM-180 & 936 & 8 & & & & & & & & & & 2.6 & \\
\hline $\mathrm{H} 2$ & 19 & 11 & 66 & 244 & & & & WM- 182 & 1101 & 7 & & & & & & & $3.1 !$ & \\
\hline $\mathrm{H}-2$ & 19 & 11 & 66 & 245 & $W M-180$ & 936 & 8 & & & & & & & & & & 2.6 & \\
\hline $\mathrm{H}-2$ & 20 & 11 & 66 & 246 & & & & WM-182 & 1101 & $7^{i}$ & & & & & & & 3.11 & \\
\hline
\end{tabular}


Table A2. Calciner Feed to Calcined Solids Storage Facility II. (contmued)

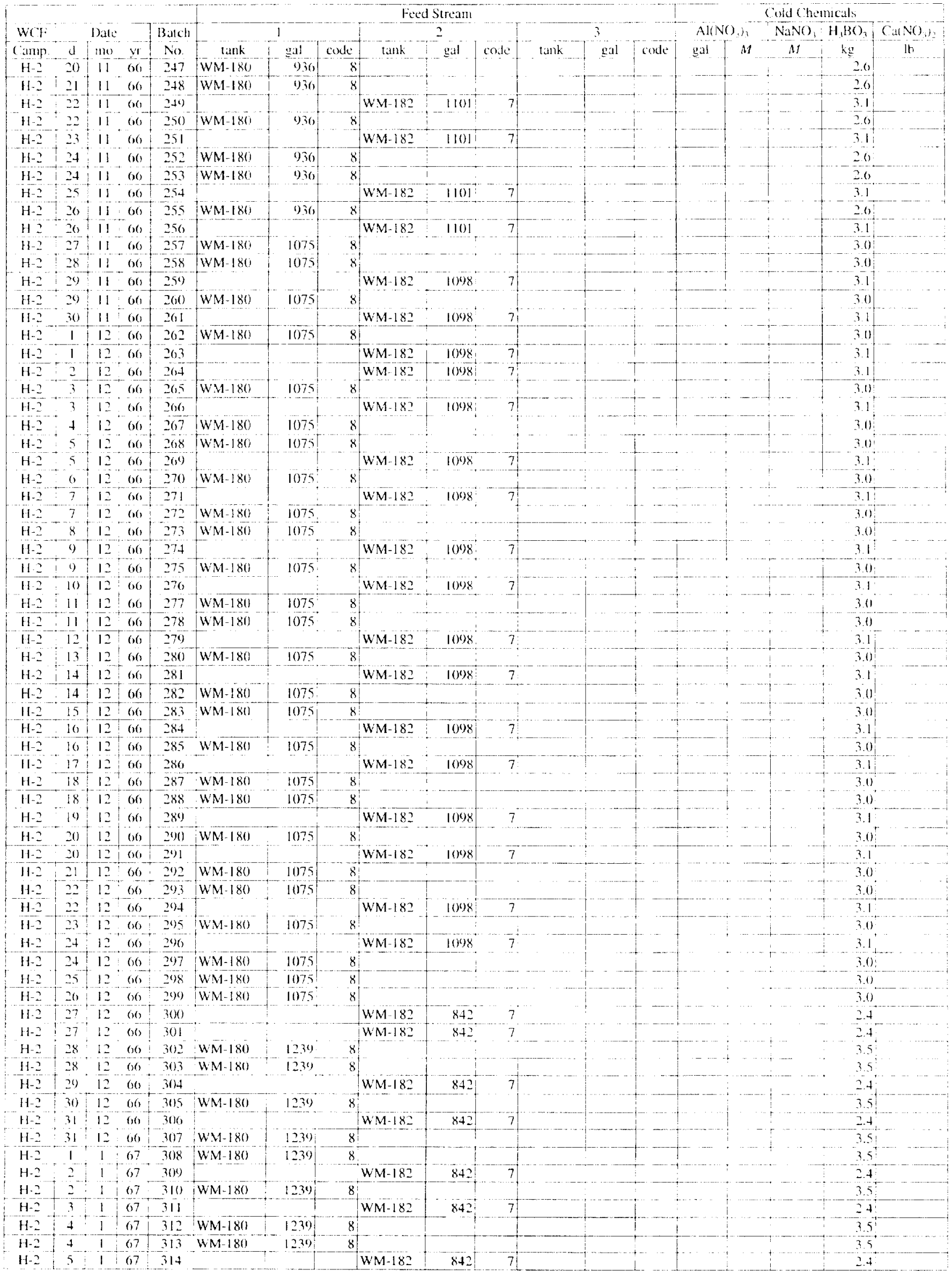


Table A2. Calciner Feed to Calcined Solids Storage Facility II. (continued)

\begin{tabular}{|c|c|c|c|c|c|c|c|c|c|c|c|c|c|c|c|c|c|c|}
\hline \multirow{3}{*}{ WCF } & & & & & \multicolumn{9}{|c|}{ Feed Stream } & \multicolumn{5}{|c|}{ Cold Chemiculs } \\
\hline & \multicolumn{3}{|c|}{ Datte } & & & 1 & & & 2 & & & 3 & & Aln & & $\mathrm{NaNO}_{3}$ & $\mathrm{H}_{3} \mathrm{BO}_{3}$ & $\mathrm{Ca}\left(\mathrm{NO}_{3}\right)_{2}$ \\
\hline & $\mathrm{d}$ & mo & $\mathrm{yr}$ & & tank & gal & code & tank & gat & code & lank & gal & cole & gal & $M$ & $M$ & $\mathrm{~kg}$ & $\mathrm{bb}$ \\
\hline $\mathrm{H}-2$ & 0 & 1 & 67 & 315 & WM-180 & 1239 & 8 & & & & & & & & & & 3.5 & \\
\hline $\mathrm{H}-2$ & 6 & 1 & 67 & 316 & & & & WM-18? & 842 & 7 & & & & & & & 2.4 & \\
\hline $\mathrm{H}-2$ & 7 & 1 & 67 & 317 & WM-180 & 1239 & 8 & & & & & & & & & & 3.5 & \\
\hline $\mathrm{H}-2$ & 7 & 1 & 67 & 318 & WM-180 & 1239 & 8 & & 1 & & & & & & & & 3.5 & \\
\hline $\mathrm{H}-2$ & 8 & 1 & 67 & 319 & & & & WM-182 & 842 & 7 & & & & & & & 2.4 & \\
\hline $\mathrm{H}-2$ & () & 1 & 67 & 320 & & & & WM-182 & $8+2$ & 7 & & & & & & & 2.4 & \\
\hline $\mathrm{H}-2$ & 10 & 1 & 67 & 321 & WM-180 & 1239 & 8 & & & & & & & & & & 3.5 & \\
\hline $\mathrm{H}-2$ & 10 & 1 & 07 & 322 & & & & WM- 182 & 842. & 7 & & & & & & & 2.4 & \\
\hline $\mathrm{H}-2$ & 11 & 1 & 67 & 323 & $W M-180$ & 1230) & 8 & & & & & & & & & & 3.5 & \\
\hline $\mathrm{H}-2$ & 12 & 1 & 67 & 324 & & & & WM- 182 & 842 & 7 & & & & & & & 24. & \\
\hline $\mathrm{H}-\mathrm{z}$ & 13 & 1 & 67 & 325 & WM-180 & 1239 & 8 & & & & & & & & & & 3.5 & \\
\hline $\mathrm{H}-2$ & 13 & 1 & 67 & 326 & & & & $W M-182$ & 842 & 71 & & & & & & & 2.4 & \\
\hline $\mathrm{H}-2$ & 14 & 1 & 67. & 327 & WM-180 & 1239 & 8 & & & 4 & & & & & & & $3.5:$ & \\
\hline $\mathrm{H}-2$ & 14 & 1 & 67 & 328 & WM-180 & 1239 & 8 & & & & & & & & & & 3.5 & \\
\hline $\mathrm{H}-2$ & 15 & 1 & 67 & 329 & & & & WM-182 & 842 & 7 & & & & & & & 24 & \\
\hline $\mathrm{H}-2$ & 15 & 1 & 67 & 330 & WM-180 & 1239 & 8 & & & & & & & & & & 3.5 & \\
\hline $\mathrm{H}-2$ & 10 & 1 & 67 & 331 & & & & WM- 182 & 842 & 7 & & & & & & & 2.4 & \\
\hline $\mathrm{H}-2$ & 17 & 1 & 67 & 332 & WM-180 & 1239 & 8 & & & & & & & & & & 3.5 & \\
\hline $\mathrm{H}-2$ & 17 & 1 & 67 & 333 & WM-180 & 1239 & 8 & & & & & & & & & & 3.5 & \\
\hline $\mathrm{H}-2$ & 18 & 1 & 67 & 334 & & & & $W M-18 ?$ & 842 & 7 & & & & & & & 2.41 & \\
\hline $\mathrm{H}-2$ & 19 & 1 & 67 & 335 & WM- 180 & 1239 & 8 & & & & & & & & & & 3.5 & \\
\hline $\mathrm{H}-2$ & 19 & 1 & 67 & 336 & & & & WM- 182 & 842 & 7 & & & & & & & 2.4 & \\
\hline $\mathrm{H}-2$ & 20 & 1 & 67 & 337 & WM-180 & 1239 & 8 & & & & & & & & & & 3.5 & \\
\hline $\mathrm{H}-2$ & 21 & 1 & 67 & 338 & WM- 180 & 1239 & 8 & & & & & & & & & & 3.5 & \\
\hline $\mathrm{H} 2$ & 21 & 1 & 67 & 339 & & & & WM-182 & 842 & 7 & & & & & & & 2.4 & \\
\hline $\mathrm{H}-2$ & 22 & $!$ & 67 & 340 & WM-180 & 1239 & 8 & & & & & & & & & & $3.5 !$ & \\
\hline $\mathrm{H}-2$ & 2.3 & 1 & 67 & 341 & & & & WM-182 & 842 & 7 [ & & & & & & & 2.4 & \\
\hline $\mathrm{H} 2$ & 23 & 1 & 67 & 342 & WM- 180 & 1239 & 8 & & & & & & & & & & 3.5 & \\
\hline $\mathrm{H}-2$ & 24 & $1:$ & 67 & 343 & WM-180 & 1239 & 8 & & & & & & & & & & 3.5 & \\
\hline $\mathrm{H}-2$ & 25 & 1 & 67 & 344 & & & & WM-182 & 8121 & $7 !$ & & & & & & & 2.4 & \\
\hline $\mathrm{H}-2$ & 25 & 1 & 67 & 345 & WM-180 & 1239 & 8 & & & & & & & & & & $3.5 !$ & \\
\hline $\mathrm{H}-2$ & 20 & 1 & 67 & 346 & & & & WM-182 & 842 & 7. & & & & & & & 2.4 & \\
\hline $\mathrm{H}-2$ & 27 & 1 & 67 & 347 & WM-180 & 1043 & 8 & & & & & & & & & & 2.9 & \\
\hline $\mathrm{H}-2$ & 27 & 1 & 67 & 348 & WM-180 & 1043 & 8 & & & & & & & & & & 2.9 & \\
\hline $\mathrm{H}-2$ & 28 & 1 & 67 & 349 & & & & WM-182 & 1038 & 7 & & & & & & & 2.9 & \\
\hline $\mathrm{H}-2$ & 29 & 1 & 67 & 350 & WM-180 & 1043 & 8 & & & & & & & & & & 2.9 & \\
\hline $\mathrm{H}-2$ & 29 & $!$ & 67 & 351 & & & & WM-182 & 1038 & 7 & & & & & & & 2.9 & \\
\hline $\mathrm{H}-2$ & 30 & 1 & 67 & 352 & WM-180 & 1043 & 8 & & & & & & & & & & 2.9 & \\
\hline $\mathrm{H}-2$ & 31 & 1 & 67 & 353 & WM-180 & 1043 & 8 & & & & & & & & & & 2.9 & \\
\hline $\mathrm{H}-2$ & 31 & 1 & 67 & 354 & & & & WM-182 & 1038 & 7 & & & & & & & 29 & \\
\hline $\mathrm{H}-2$ & 1 & 2 & 67 & 355 & WM-180 & 1043 & 8 & & & & & & & & & & 2.9 & \\
\hline $\mathrm{H}-2$ & 2 & 2 & 67 & 356 & & & & WM-182 & 1038 & 7 & & & & & & & 2.9 & \\
\hline $\mathrm{H}-2$ & 2 & 2 & 67 & 357 & WM-180 & 1043 & 8 & & & & & & & & & & 2.9 & \\
\hline $\mathrm{H}-2$ & 3 & 2 & 67 & 358 & WM- 180 & $1043]$ & 8 & & & & & & & & & & 2.9 & \\
\hline $\mathrm{H} \cdot 2$ & 4 & $=$ & 67 & 359 & & & & WM-182 & 1038 & 7 & & & & & & & 2.9 & \\
\hline $\mathrm{H}-2$ & 4 & 2 & 67 & 360 & WM- 180 & 1043 & 8 & & & & & & & & & & 2.9 & \\
\hline $\mathrm{H}-2$ & 5 & 2 & 67 & 361 & & & & WM-182 & 1038 & 7 & & & & & & & 2.9 & \\
\hline $\mathrm{H}-2$ & 6 & 2 & 67 & 362 & WM-I 80 & 1043 & 8 & & & & & & & & & & 29 & \\
\hline $\mathrm{H}-2$ & 6 & 2 & 67 & 363 & WM-1 80 & 1043 & $8:$ & & & & & & & & & & 2.9) & \\
\hline $\mathrm{H}-\mathrm{Z}$ & 7 & 2 & 67 & 364 & & & & $W M-182$ & $\mid 1038$ & 7) & & & & & & & 2.9 & \\
\hline $\mathrm{H}-2$ & 8 & 2 & 67 & 365 & WM-180 & 1043 & 8 & & & & & & & & & & 29 & \\
\hline$H ?$ & 8 & 2 & 67 & 366 & & & & WM-185 & 1038 & 7 & & & & & & & 2.9 & \\
\hline$H-2$ & 9 & 2 & 67 & 367 & WM-180 & 1043 & 8 & & & & & & & & & & $2.9 \mathrm{j}$ & \\
\hline $\mathrm{H}-2$. & 10 & 2 & 67 & 368 & WM-180) & $10+3$ & 8 & & & & & & & & & & 2.9 & \\
\hline $\mathrm{H}-2$ & io & 3 & 67 & 364 & & & & WM-182 & 1038 & 7 . & & & & & & & 29 & \\
\hline $\mathrm{H}-2$ & 11 & 2 & 67 & 370 & WM-180 & 1043 & & & & & & & & & & & 29 & \\
\hline $\mathrm{H} \cdot 2$ & 12 & $2^{2}-1$ & 67 & 371 & & & & WM-182 & 1038 & 7 & & & & & & & 2.9 & \\
\hline $\mathrm{H}-2$ & 12 & 2 & 67 & 372 & WM-180 & 1043 & 8 & & & & & & & & & & 29 & \\
\hline $\mathrm{H}-2$ & 13 & 2 & 67 & 373 & WM-180 & 1043 & 8 & & & & & & & & & & 2.9 & \\
\hline $\mathrm{H}-2$ & 14 & 2 & 67 & 374 & & & & $W M-182$ & 1038 & 71 & & & & & & & 29 & \\
\hline $\mathrm{H}-2$ & 14 & 2 & 67 & 375 & $W M-180$ & 1043 & 8 & & & $1-$ & & & & & & & 2.9 & \\
\hline $\mathrm{H}-2$ & 15 & 2 & 67 & 376 & & & & WM-182 & 1038 & $7^{1}$ & & & & & & & 29 & \\
\hline $\mathrm{H}-2$ & 16 & 2 & 67 & 377 & WM-180 & 1043 & $8:$ & & & & & & & & & & 29 & \\
\hline $\mathrm{H}-2$ & 17 & 2 & 67 & 378 & WM-180 & 1043 & 8 & & & & & & & & & & 29 & \\
\hline $\mathrm{H}=2$ & 17 & 2 & 67 & $37 \%$ & & & & WM-182 & 1038 & 7 & & & & & & & 29 & \\
\hline $\mathrm{H}-2$ & 18 & 2 & 67 & $380^{\circ}$ & $\overline{W M}-180$ & 1043 & 8 & & & & & & & & & & 2.9 & \\
\hline $\mathrm{H}-2$ & 19 & 2 & 67 & 381 & & & & WM-182 & 1038 & 7 & & & & & & & 2.9 & \\
\hline $\mathrm{H}-2$ & 19 & 2 & 67 & 382 & WM- 180 & 1043 & & & & & & & & & & & $2.9 !$ & \\
\hline
\end{tabular}


Table A2. Calciner Feed to Calcined Solids Storage Facility II. (continued)

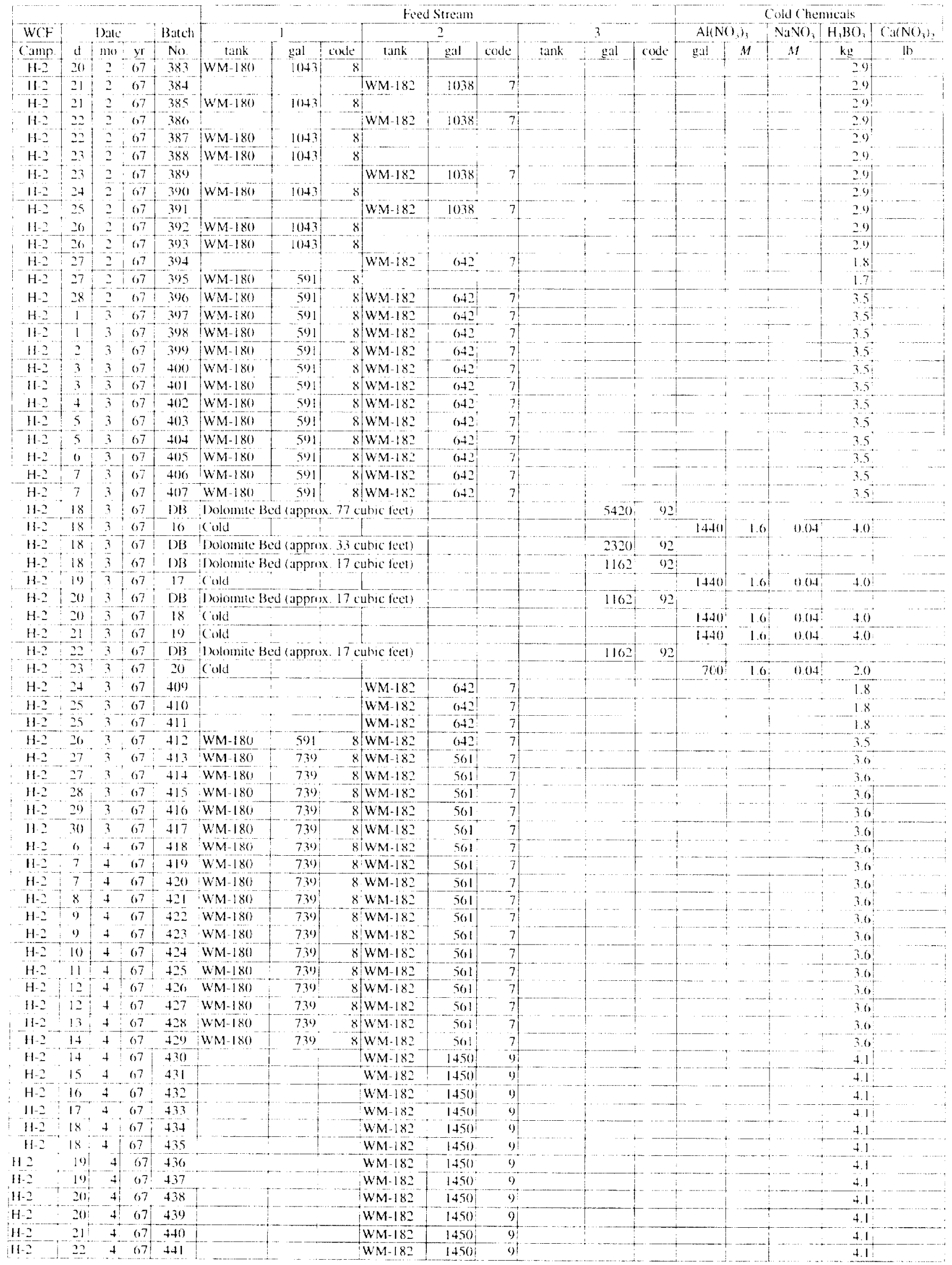


Table A2. Calciner Feed to Calcined Solids Storage Facility II. (continued)

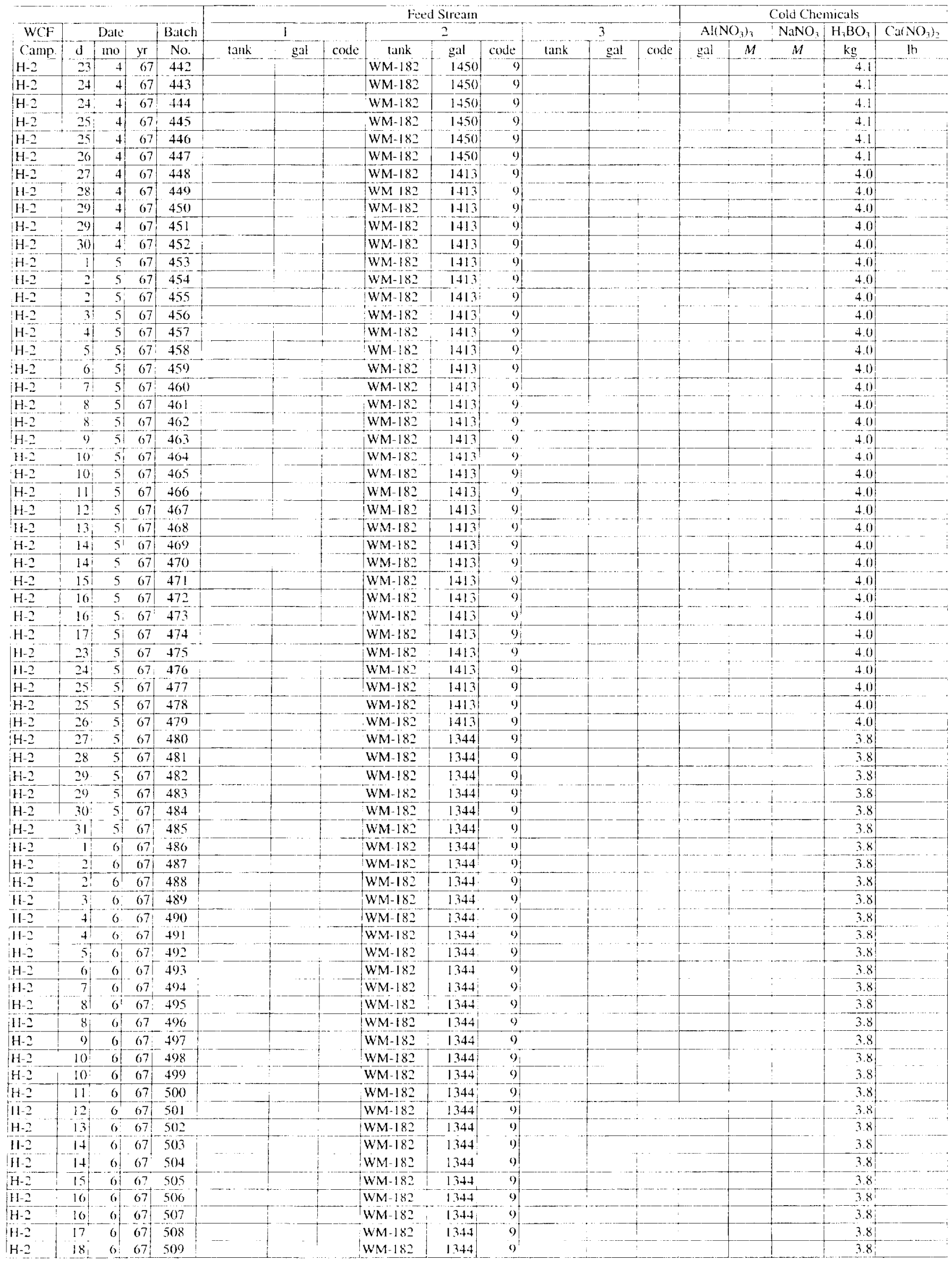


Table A.2. Calciner Feed to Calcined Solids Storage Facility II. (continued)

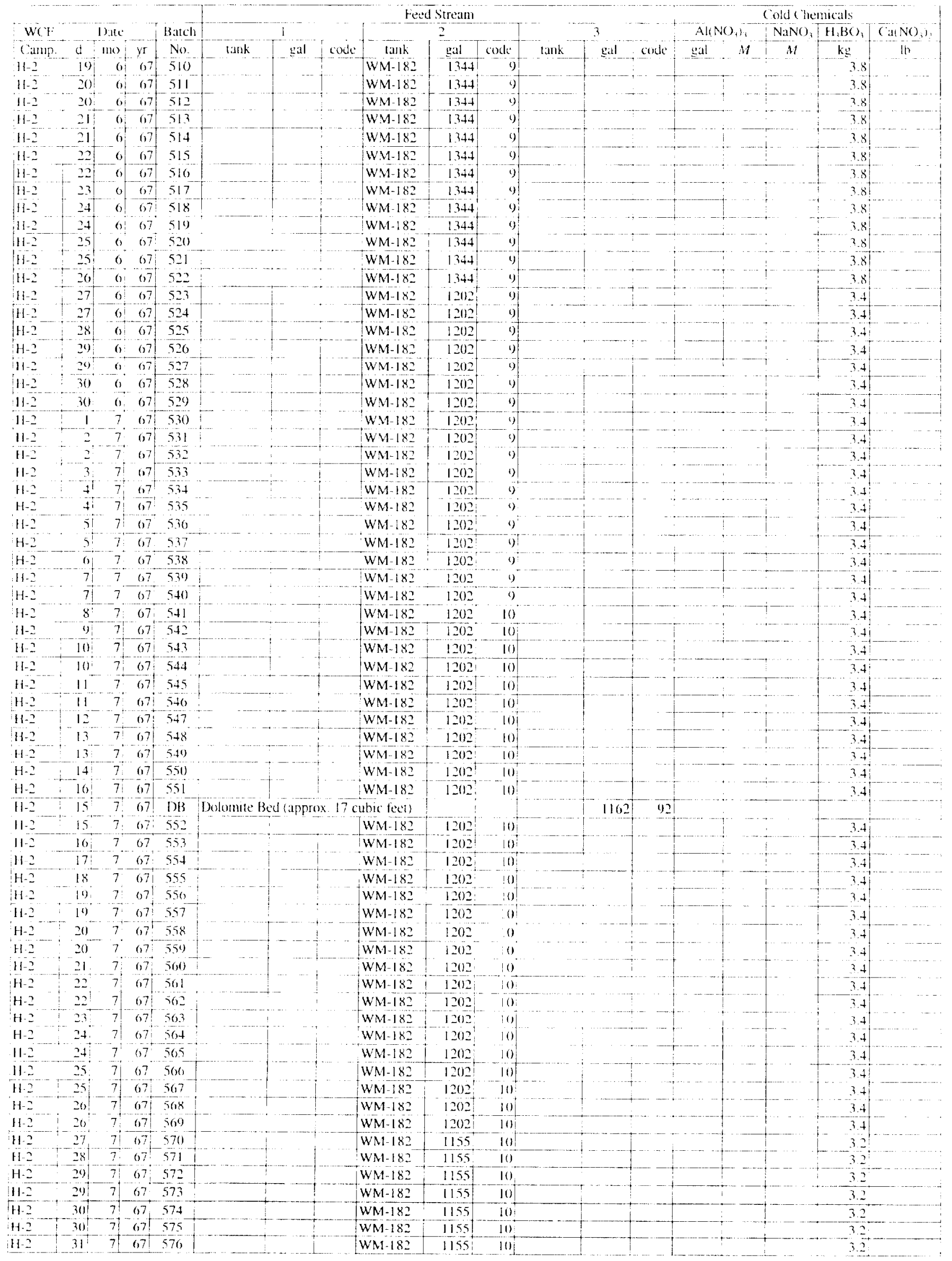


Table A2. Calciner Feed to Calcined Solids Storage Facility II. (continued)

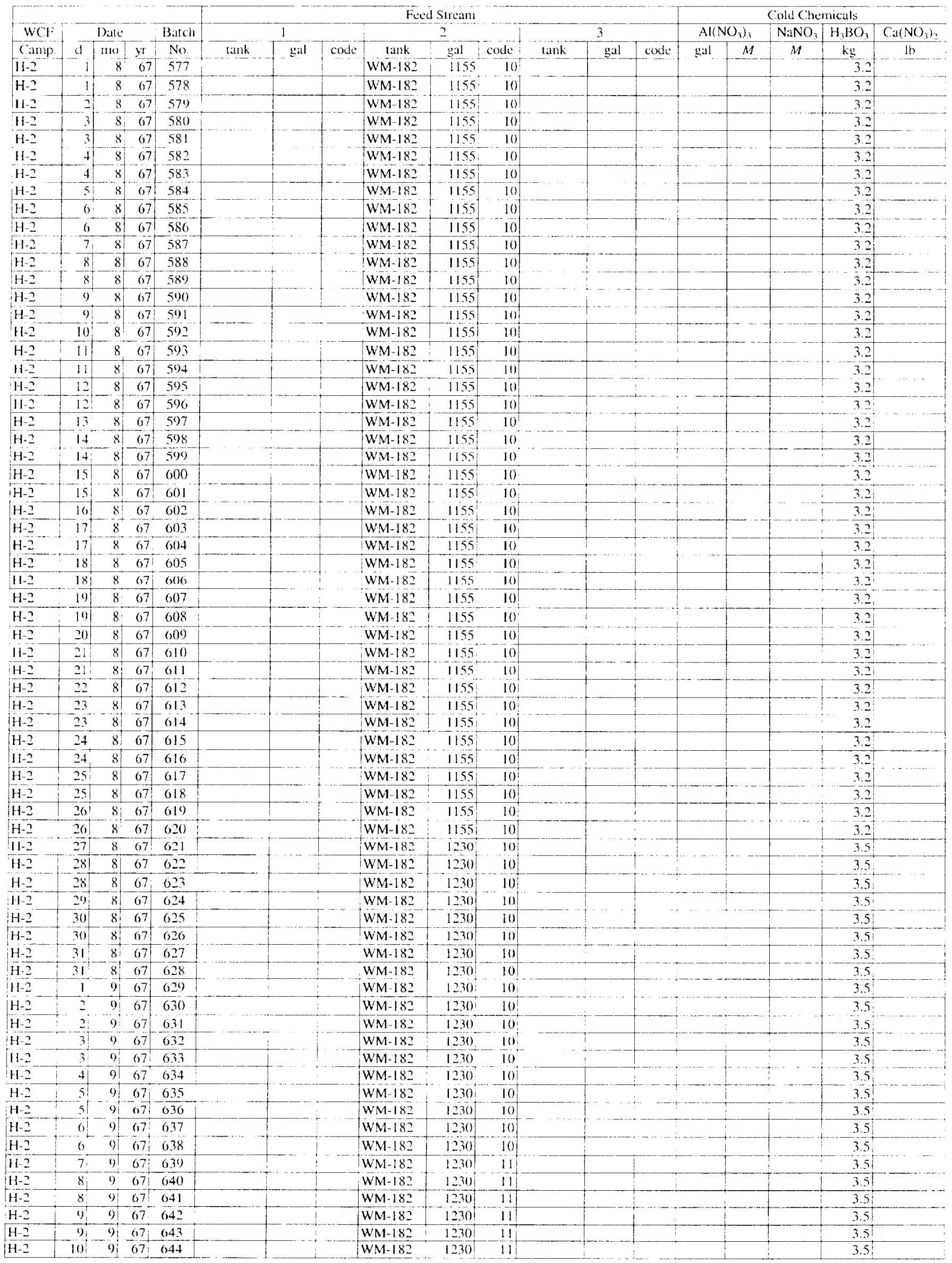


Table A2. Calciner Feed to Calcined Solids Storage Facility II. (continued)

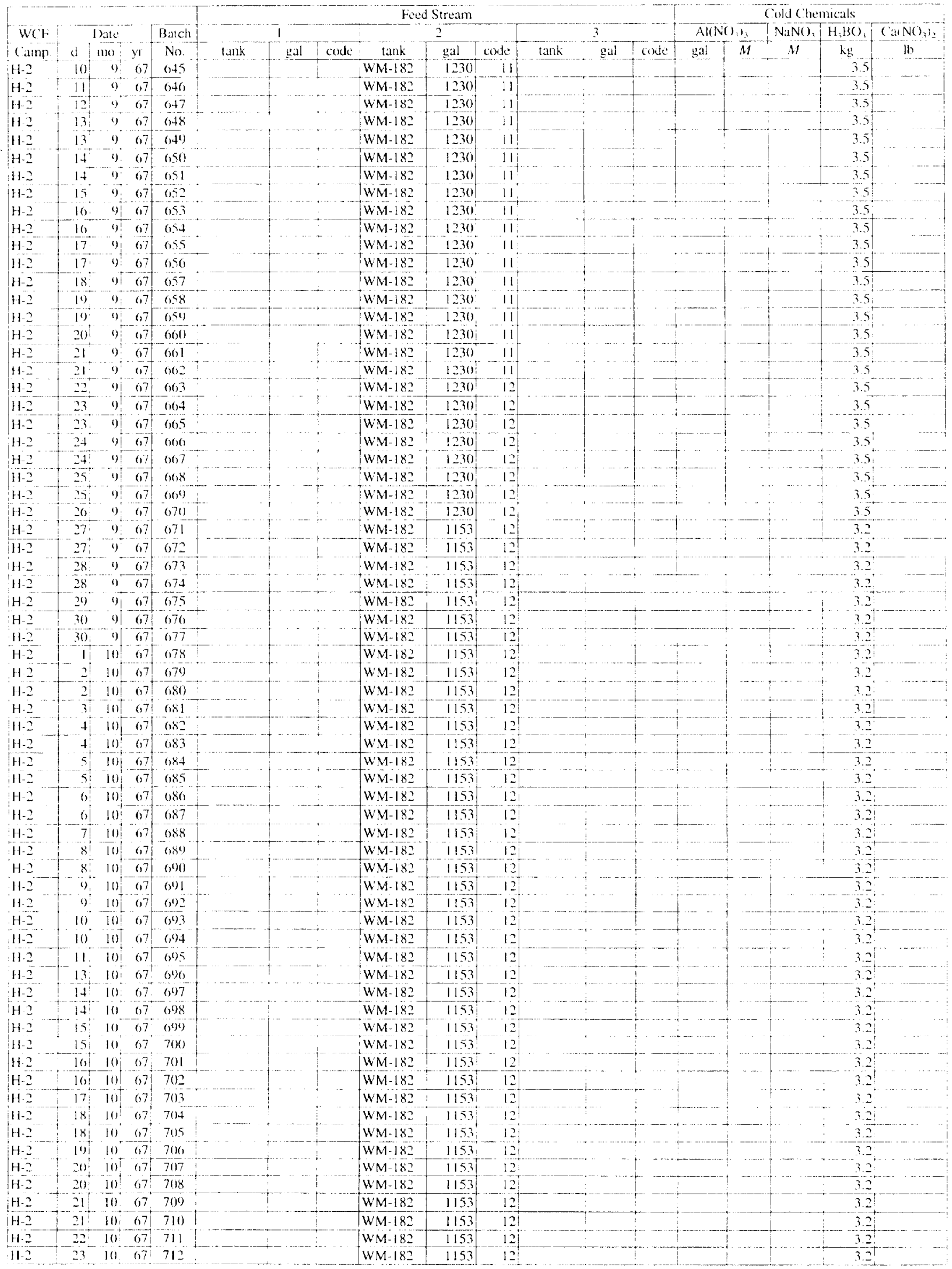


Table A2. Calciner Feed to Calcined Solids Storage Facility II. (continued)

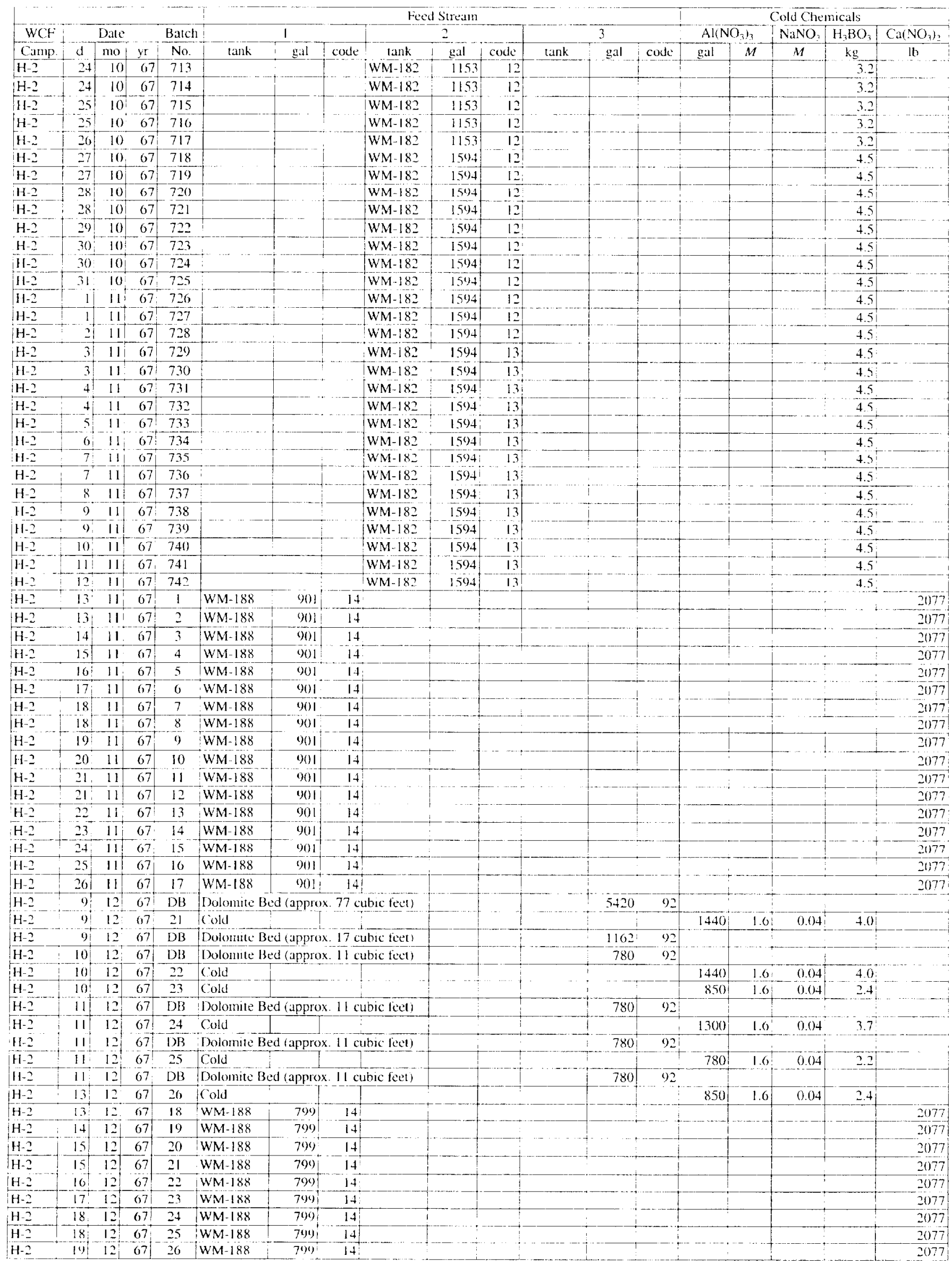


Table A2. Calciner Feed to Calcined Solids Storage Facility Il. (continued)

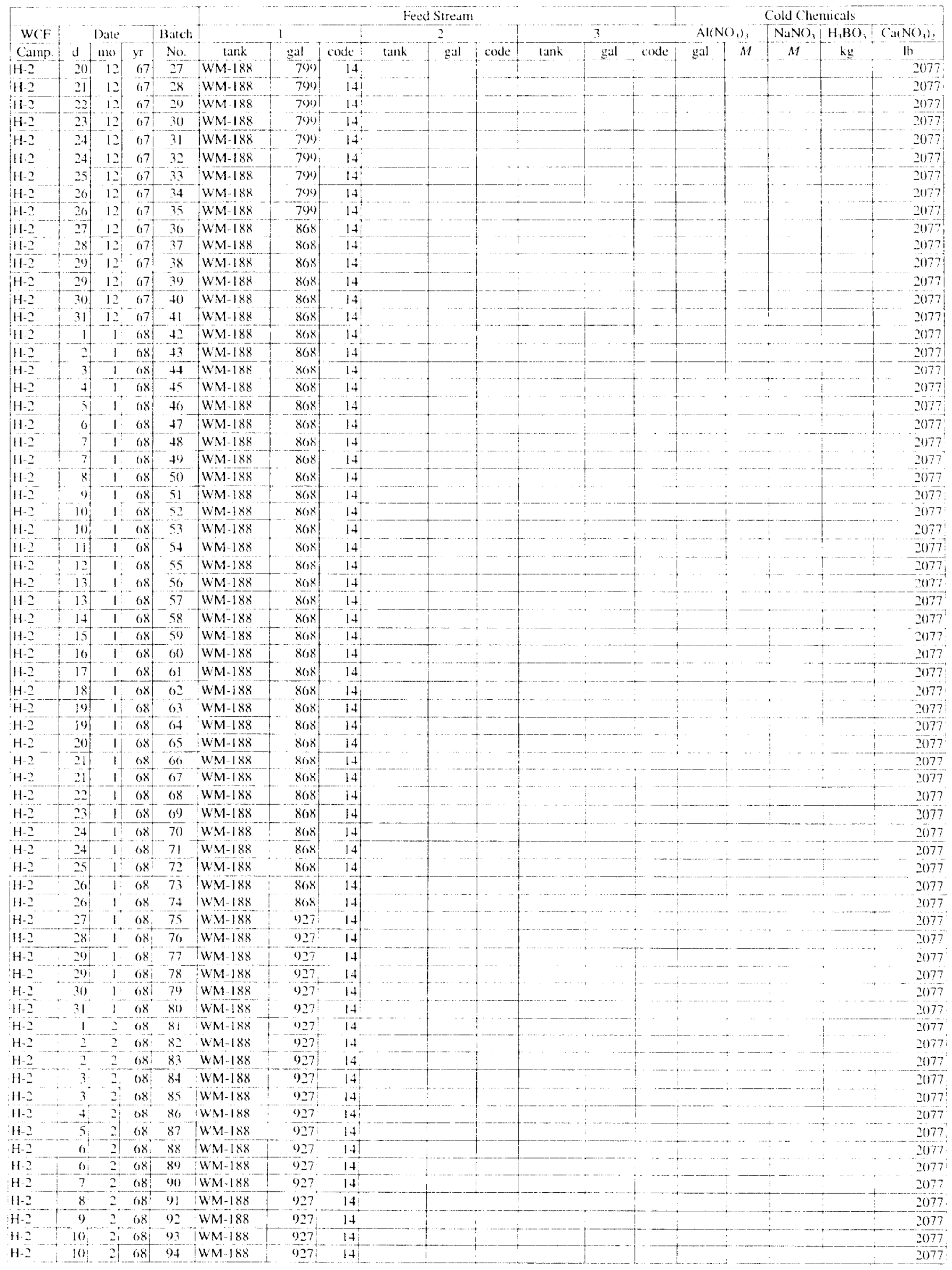


Table A2. Calciner Feed to Calcined Solids Storage Facility II. (continued)

\begin{tabular}{|c|c|c|c|c|c|c|c|c|c|c|c|c|c|c|c|c|c|c|}
\hline & & & & \multirow{3}{*}{$\frac{\text { Batch }}{\text { No. }}$} & \multirow{2}{*}{\multicolumn{9}{|c|}{ Feed Stream }} & \multicolumn{5}{|c|}{ Cold Cluemicals } \\
\hline & & Date & & & & 1 & & & & & & & & $\mathrm{Al}(\mathrm{NC}$ & $\left.\mathrm{O}_{3}\right)_{3}$ & $\mathrm{NaNO}_{3}$ & $\mathrm{H}_{4} \overrightarrow{\mathrm{BO}_{3} \mathrm{~T}}$ & $\mathrm{CarNO} \mathrm{N}_{3}$ \\
\hline Camp. & d & mo! & $y \mathrm{r}$ & & tulik & gal & code & tank & gal & conde & tink & gal & code & gal & $M$ & $M$ & $\mathrm{~kg}$ & $\mathrm{lb}$ \\
\hline $\mathrm{H}-2$ & 11 & 2 & 68 & 95 & WM-188 & 427 & $1+$ & & & & & & & & & & & 2017 \\
\hline $\mathrm{H}-2$ & 11 & $2 !$ & 68 & 96 & WM-188 & 927 & 14 & & & & & & & & & & & 2077 \\
\hline $\mathrm{H}_{2}$ & 12 & 2 & 68 & 97 & WM-188 & 927 & 14 & & & & & & & & 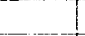 & & & 2077 \\
\hline $\mathrm{H}-2$ & 13 & 2 & 68 & 98 & WM-188 & 927 & $1+$ & & & & & $\ldots$ & & & & & & 2077 \\
\hline $\mathrm{H}-2$ & 14 & 2 & 68 & $9 \%$ & WM-188 & (927 & 14 & & & & & & & & & & & 2077 \\
\hline $\mathrm{H}=2$ & 14 & $=1$ & 68 & 100 & WM-188 & 927 & 14 & & . & - & & & & & & & & 2077 \\
\hline $\mathrm{H}-2$ & 155 & 2 & 08 & 101 & WM-188 & 927 & 14 & & & - & & & & & & & & 2077 \\
\hline $\mathrm{H}-2$ & 16 & $=$ & 68 & 102 & WM-188 & 427 & 14 & & & - & & & & & & & & 2077 \\
\hline $\mathrm{H}-2$ & $177^{\dagger}$ & 2 & 68 & 103 & WM-188 & 927 & 14 & & & 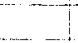 & & 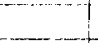 & & & & & & 2077 \\
\hline $\mathrm{H}-2$ & 17 & 2 & 68 & 104 & WM-188 & 927 & 14 & & & & & - & & & & & & 2077 \\
\hline $\mathrm{H}-2$ & 18 & 2 & 68 & 105 & WM-188 & 927 & 14 & & & & & - & & & & & & 2077 \\
\hline $\mathrm{H}-2$ & 19 & 2 & 68 & 106 & WM-188 & 927 & 14 & & & & & & & & & & & 2077 \\
\hline $\mathrm{H}-2$ & 20 & 2 & 68 & 107 & WM-188 & $927 !$ & $1+1$ & & & & & & & & & & & 2077 \\
\hline $\mathrm{H}-2$ & $21+$ & 2 & 68 & 108 & WM-188 & 927 & 14 & & & & & & & & & & & 2077 \\
\hline $\mathrm{H}-2$ & $22 !$ & 2 & 68 & 109 & WM-188 & 927 & 14 & & & & & & & & & & & 2077 \\
\hline $\mathrm{H}-2$ & $22 !$ & 2 & 68 & 110 & WM-188 & 927 & 14 & & & & & & & & $\ldots$ & 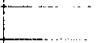 & & 2077 \\
\hline $\mathrm{H}-2$ & 23 & 2 & 68 & 111 & WM-188 & 927 & 14 & & & & & & & & & & & 2077 \\
\hline $\mathrm{H}=$ & 24 & 2 & 68 & 112 & WM-188 & 927 & 14 & & & & & & & & & & & 2077 \\
\hline $\mathrm{H}=2$ & 25 & 2 & 68 & 113 & WM-188 & 927 & 14 & & & & & & & & & & & 2077 \\
\hline $\mathrm{H}-2$ & 25 & 2 & 68. & 114 & WM-188 & 927 & 14. & & & & & & & & & & & 2077 \\
\hline $\mathrm{H}-\mathrm{2}$ & 26 & 2 & 68 & 115 & WM-188 & 927 & 14 & & & $\cdots$ & & & & & & & & 2077 \\
\hline $\mathrm{H}-2$ & 27 & 2 & 68 & 116 & WM-1 88 & 651 & 14 & & & & & & & & & & & 2077 \\
\hline $\mathrm{h} 2$ & 28 & 2 & 68 & 117 & WM-188 & 051 & 14 & & & & & & & & & & & 2077 \\
\hline $\mathrm{H}-2$ & 28 & 2 & 68 & 118 & WM-188 & 051 & 14 & & & & & & & & & & & 2077 \\
\hline $\mathrm{H}-2$ & 29 & 2 & 68 & 119 & WM-188 & 051 & 14 & & & & & & & & & & & 2077 \\
\hline$H=2$ & 1 & 3 & 68 & 120 & WM-188 & 651 & 14 & & & & - & & & & & & 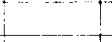 & 2077 \\
\hline $\mathrm{H}=\mathrm{Z}$ & 2 & 3 & 08 & 121 & WM-188 & 651 & 14 & & & & & & & & & & & 2077 \\
\hline $\mathrm{H}-2$ & 3 & 3 & 68 & 122 & WM-188 & 651 & 14 & & & $\ldots$ & & & & & . & & - & 2077 \\
\hline $\mathrm{H}-\mathrm{Z}$ & 3 & 3 & 68 & 123 & WM-188 & 651 & 14 & & & & & & & & & & 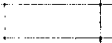 & 20177 \\
\hline $\mathrm{H}-2$ & 4 & 3 & 68 & 124 & WM-188 & $65 i$ & 14 & & 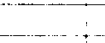 & 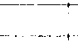 & & & & & & & & 2077 \\
\hline $\mathrm{H}-2$ & 5 & 3 & 68 & 125 & WM-188 & 654 & 14 & & & & & & & & & & & 2077 \\
\hline $\mathrm{H}=2$ & 5 & 3 & 68 & 126 & WM-188 & 651 & 14 & & & - & & & & & & & & 2077 \\
\hline 11.2 & 6 & 3 & 68 & 127 & WM-188 & 651 & 14 & & & & & & & & & & & 20777 \\
\hline $\mathrm{H}-2$ & 7 & 3 & 68 & 744 & & & & WM- 185 & 1099 & 15 & & & & & & & 3.1 & \\
\hline $\mathrm{H}-2$ & 7 & 3 & 68 & 745 & & & & WM-185 & $\mid 10 \% \%$ & 15 & & & & & & & 3.1 & \\
\hline $\mathrm{H}-2$ & 8 & 3 & 68 & 746 & & & & WM- 185 & $10 \% 9$ & 15 & & & & & & & 3.1 & \\
\hline $\mathrm{H}-\mathrm{Z}$ & (9) & 3 & 68 & 747 & & & & WM-185 & 1099 & 15 & & & & & & & 3.1 & \\
\hline $\mathrm{H}-2$ & 10 & 3 & 68 & 748 & & & & WM-185 & 1099 & 15 & & & & & & & 3.1 & \\
\hline $\mathrm{H}-2$ & 111 & 3 & 68 & 749 & & & & WM- 185 & $10999_{1}^{\prime}$ & 15 & & & & & & & 3.1 & \\
\hline $\mathrm{H} 2$ & $11 !$ & 3 & 68 & 750 & & & & WM- 185 & $\mid 1099$ & 15 & & & & & & & $3.1 \uparrow$ & \\
\hline $11-2$ & 12 & 3 & 68 & 751 & & & & $W M-185$ & 1099 & 15 & & & & & & & 3.1 & \\
\hline $\mathrm{H}-2$ & 12 & 3 & 68 & 752 & & & & WM-185 & 1099 & 15 & & & & & & & 3.1 & \\
\hline $\mathrm{H}-2$ & $13 !$ & 3 & 68 & 753 & & & & $\mathrm{WM}-185$ & 1099 & 15 & & & & & & & 3.1 & \\
\hline $\mathrm{H}-2$ & 14 & 3 & 68 & 754 & & & & $W M-185$ & $1(199)$ & 15 & & & & & & & 3.1 & \\
\hline $\mathrm{H}_{2}$ & 15 & 3 & 68 & 755 & & & & $W M-185$ & 1099 & 15 & & & & & & & 3.1 & \\
\hline $\mathrm{H}-2$ & 15 & $3 !$ & 68 & 756 & & & & WM- 185 & $10^{409}$ & 15 & & & & & & & 3.1 & \\
\hline $\mathrm{H}-2$ & 16 & $3 i$ & 68 & 757 & & & & WM-185 & 1099 & 15 & & & & & & & 3.1 & \\
\hline $\mathrm{H}-2$ & 17 & 3 & 68 & 758 & & & & WM- 185 & 1009 & 15 & & & & & & & 3.1 & \\
\hline $\mathrm{H}-2$ & 18 & 3 & 68 & 759 & & & & WM-185 & 1099 & 15 & & & & & & & 3.1 & \\
\hline $\mathrm{II}-2$ & $19 !$ & 3 & 681 & 760 & & & & WM-185 & $\left.10^{6}+1\right)$ & 15 & & & & & & & 3.1 & \\
\hline $\mathrm{H}-2$ & 19: & 3 & 68 & 761 & & & & WM-185 & $1099 !$ & 15 & & & & & & & $3.1^{1}$ & \\
\hline $111-2$ & 20 & 3 & 68 & 762 & & & & WM-185 & 1094 & 15 & & & & & & & 31 & \\
\hline $\mathrm{H}-2$ & 21 & $3 i$ & 68 & 763 & & & & WM- 185 & $1009\}$ & 15 & & & & & & & 31 & \\
\hline $\mathrm{H}-2$ & 221 & 3 & $68 !$ & 764 & & & & WM-185 & $1090 !$ & 15 & & & & & & & 31 & \\
\hline $\mathrm{H}-2$ & 221 & 3 & 68 & 765 & & & & WM-I85 & $1099 !$ & 15 & & & & & & & 31 & \\
\hline $\mathrm{H}-2$ & 23 & 3 & 68 & 760 & & & & WM- 185 & 1090 & 15 & & & & & & & 3.1 & \\
\hline $\mathrm{H}-3$ & 8 & 8 & $68 t$ & $\mathrm{DB}^{-}$ & Dolomie B & d (appro: & x. $83 \mathrm{cu}$ & ubic feet! & & & & 5810 & 92 & & & & & \\
\hline $\mathrm{H}-3$ & 8 & 8 & 68 & 10 & cold & & & & & & & & & 1166 & 1.6 & & 33 & \\
\hline $\mathrm{H}-3$ & 9 & 8 & 68 & 20 & Cold & & & & & & & & & 1220 & 1.6 & & 34 & \\
\hline $11-3$ & 10 & 8 & 68 & $3 C$ & Cold & & & & & & & & & 1160 & 1.64 & & 33 & \\
\hline $\mathrm{H}-3$ & 161 & 8 & 68 & $4 C$ & Cold & & & & & & & & & 712 & 1.6 & & 2.0 & \\
\hline $\mathrm{H}-3$ & 11 & 8 & 68 & 50 & Coold & & & & & & & & & 1207 & 1.6 & & 34 & \\
\hline $\mathrm{H}-3$ & 11 & 8 & 68 & $6 C$ & Cold & & & & & & & & & 1241 & 1.6 & & 3.5 & \\
\hline $\mathrm{H}-3$ & 12 & 8 & 68 & 70 & Cold & & & & & & & & & 744 & 1.6 & & 2.1 & \\
\hline $11-3$ & 12 & 8 & 68 & $80^{\circ}$ & Cold & & & & & & & & & $1+30$ & 1.6 & & 40 & \\
\hline $\mathrm{H}-3$ & 13 & 8 & 68 & $9 \mathrm{C}$ & Cold & & & & & & & & & 890 & 1.6 & & 2.5 & \\
\hline $\mathrm{H}-3$ & 14 & 81 & 68 & $10 \mathrm{C}$ ? & Cold & & & & & & & & & 1063 & 16 & & 3.0. & \\
\hline $\mathrm{H}-3$ & 14 & $8 !$ & 681 & 11 & $W M-188$ & 803 & 16. & & & & & & & & & & & 1030 \\
\hline
\end{tabular}


Table A2. Calciner Feed to Cakined Solids Storage Facility II. (continued)

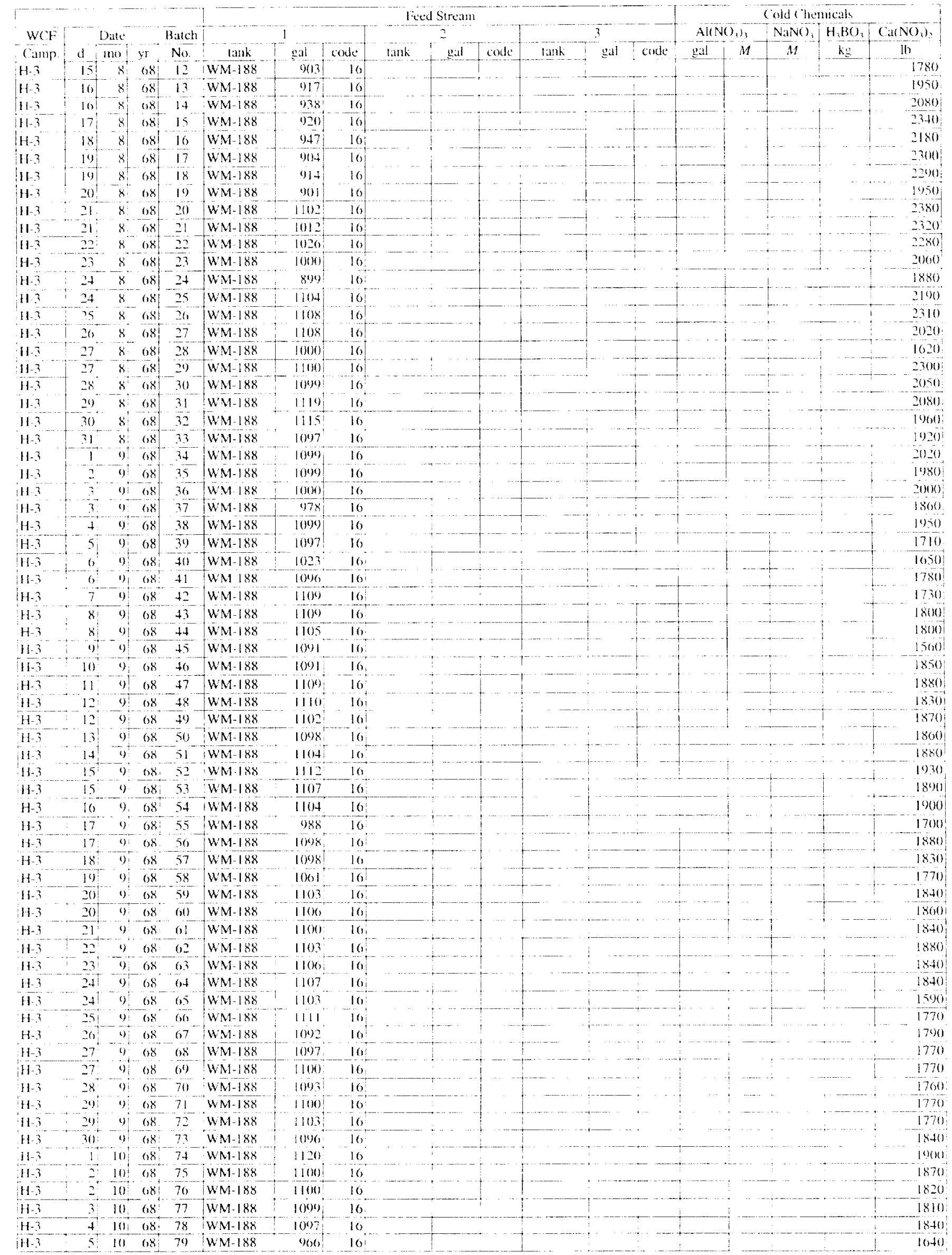


Table A2. Calciner Feed to Calcined Solids Storage Facility II. (continued)

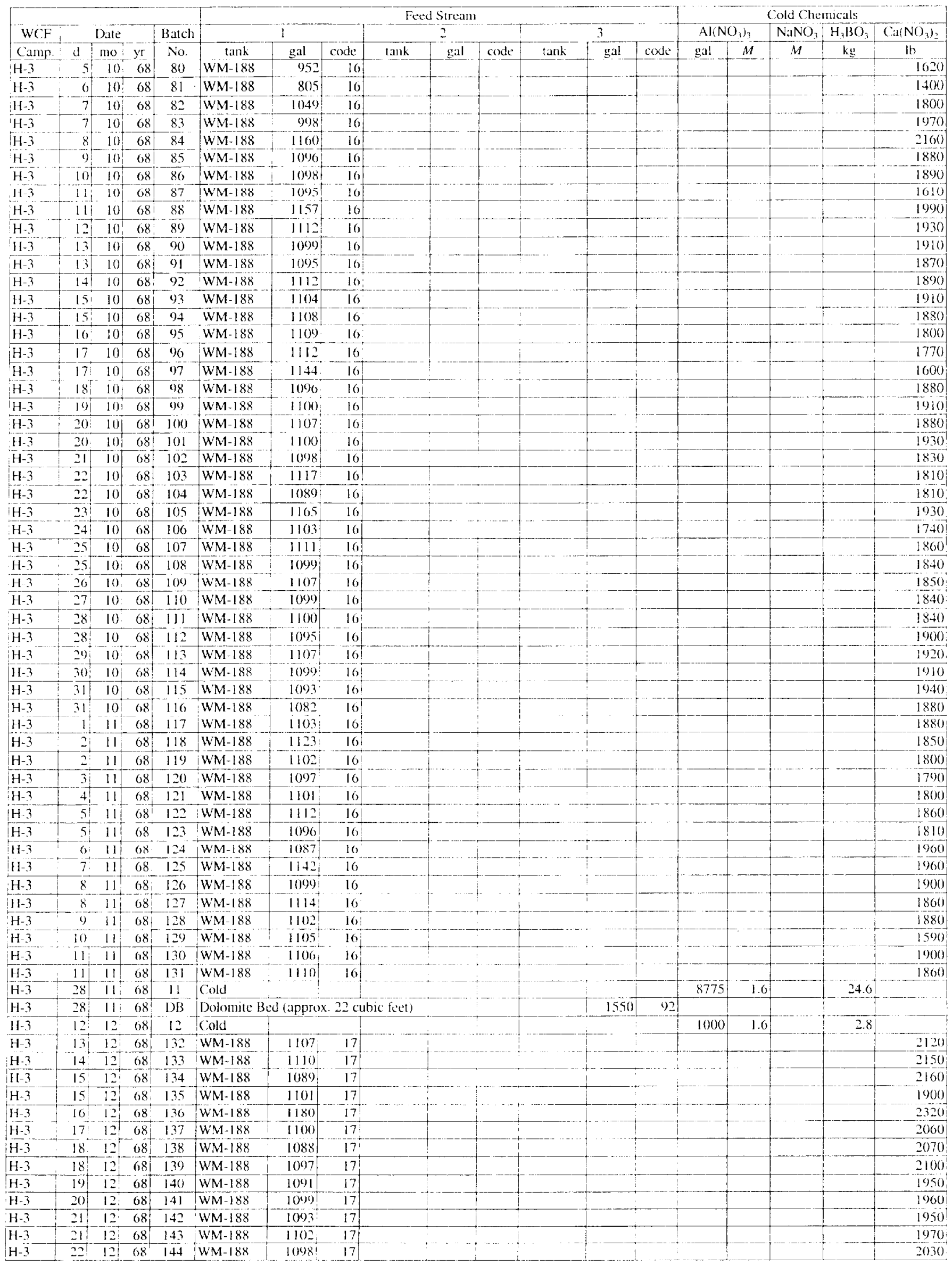


Table A2. Calciner Feed to Calcined Solids Storage Facility II. (continued)

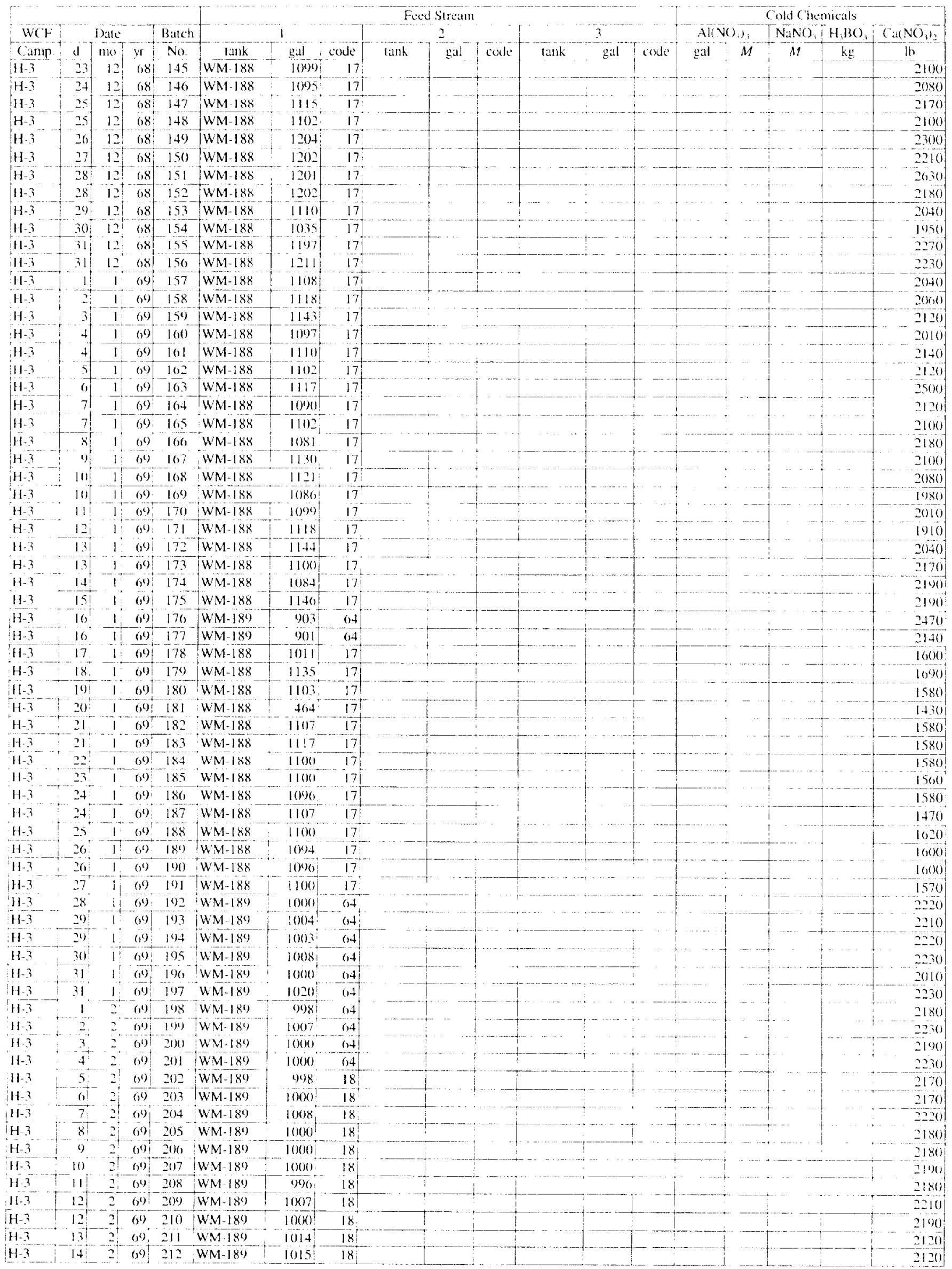


Table A2. Calciner Feed to Calcined Solids Storage Facility II. (continued)

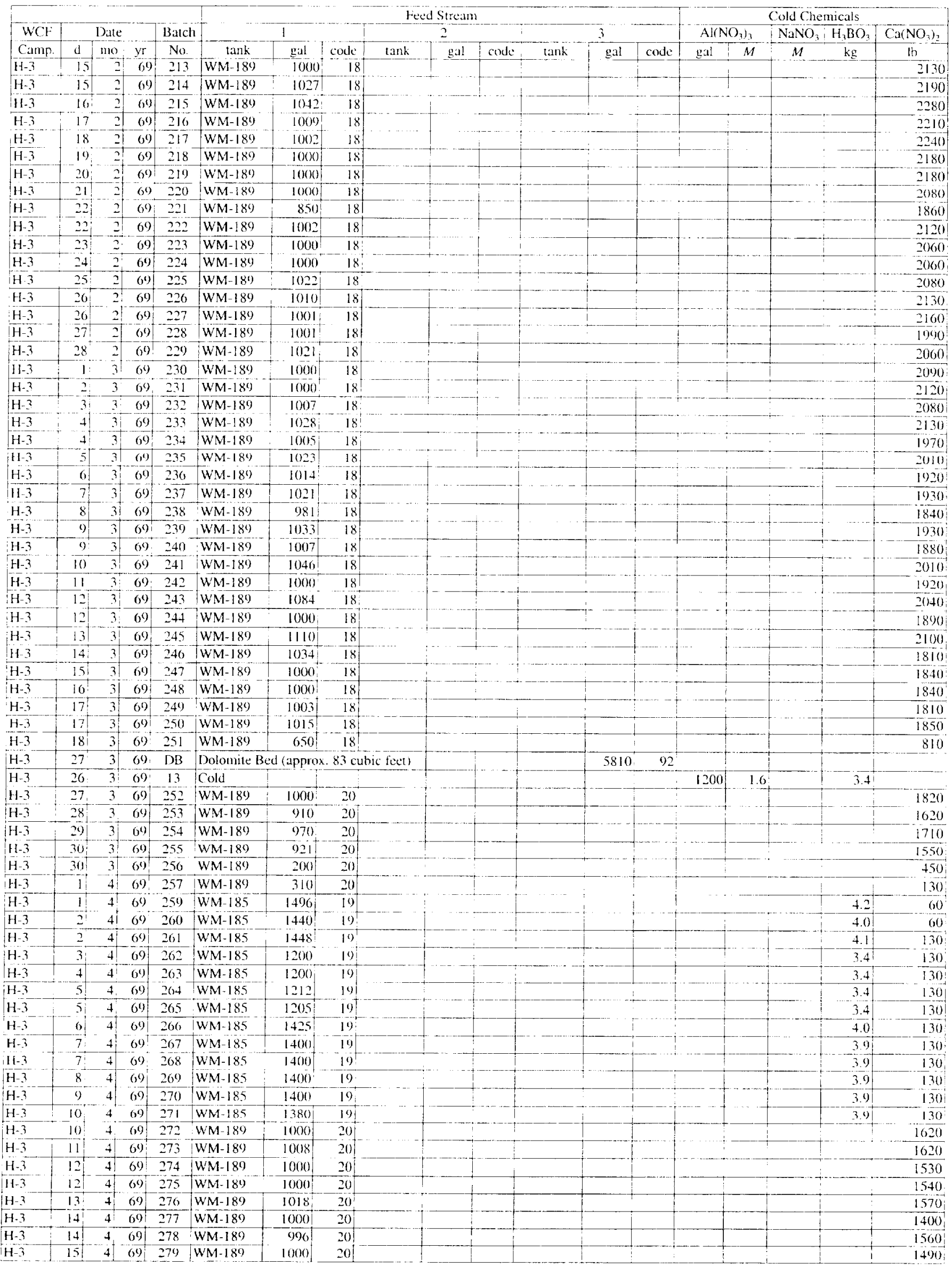


Table A2. Calciner Feed to Calcined Solids Storage Facility Il. (continued)

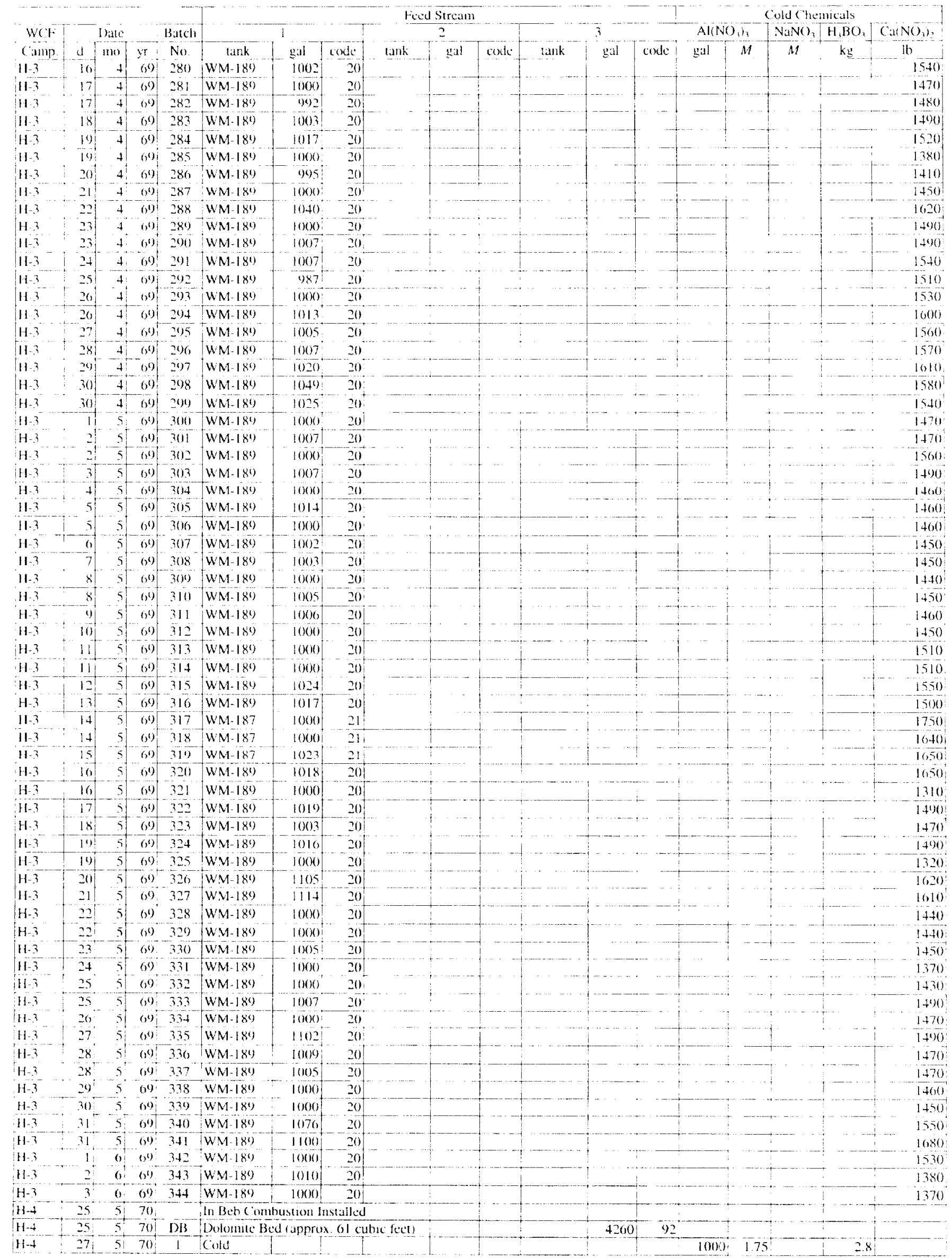


Table A2. Calciner Feed to Calcined Solids Storage Facility II. (continued)

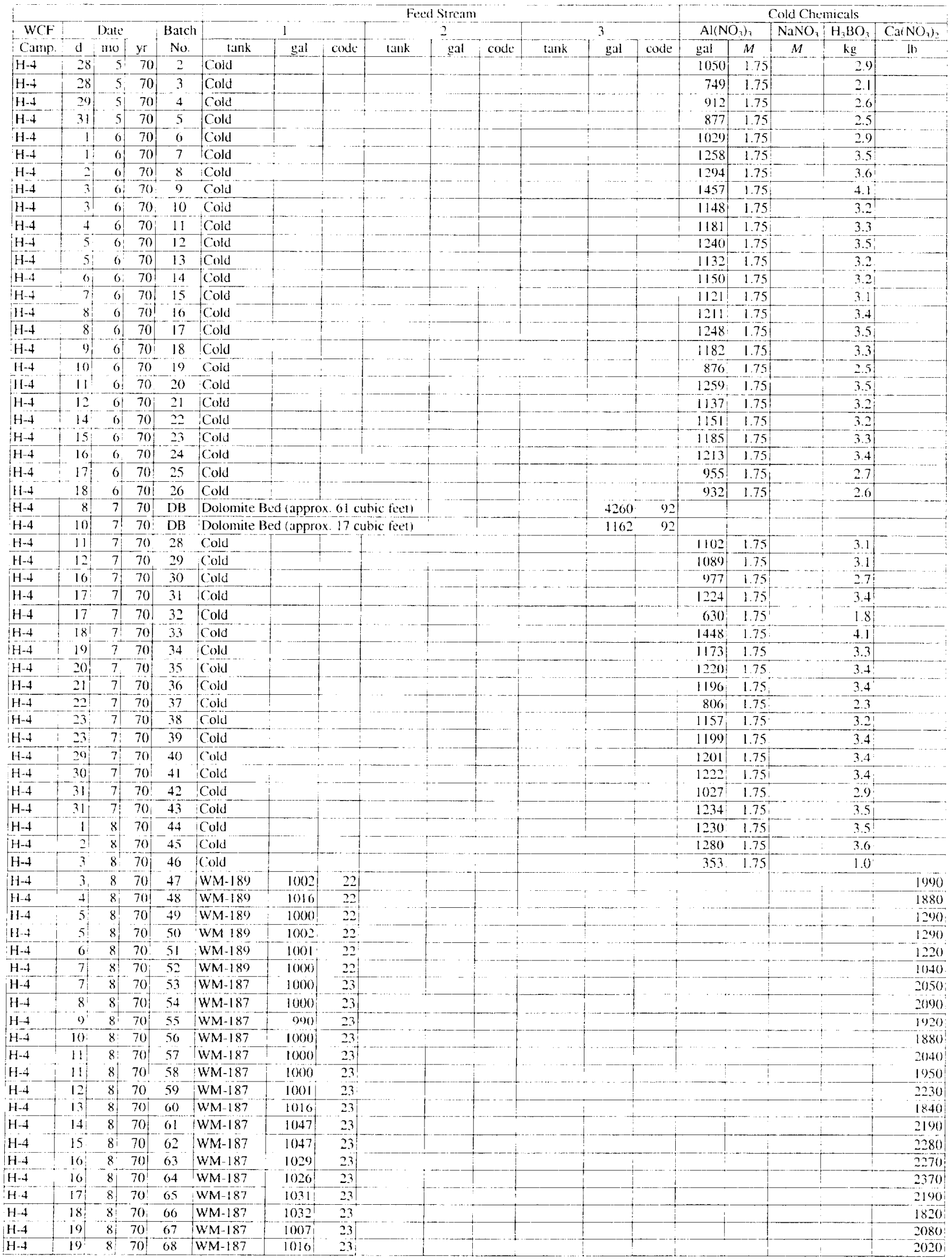


Table A2. Calciner Feed to Calcined Solids Storage Facility II. (continued)

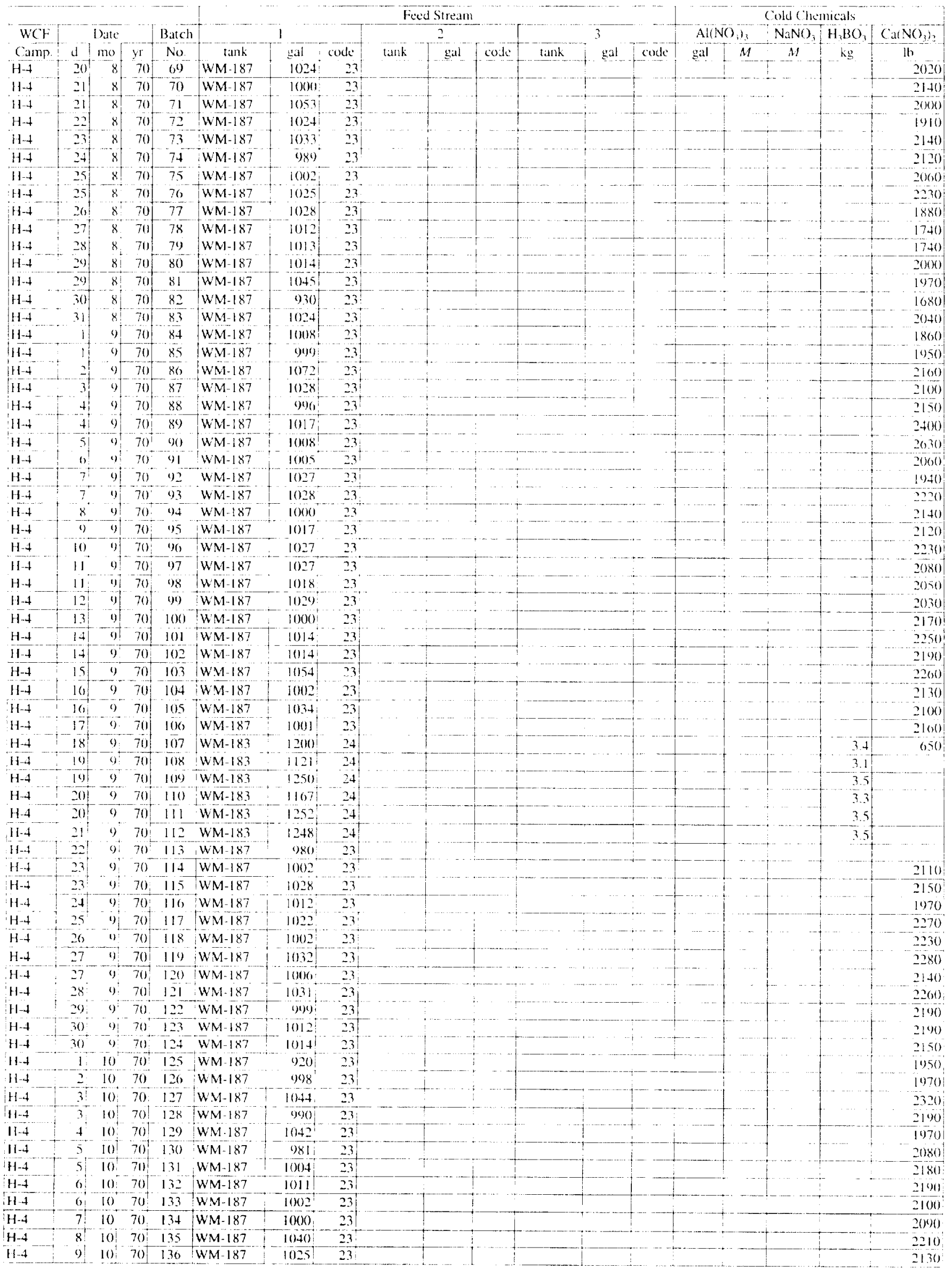


Table A2. Calciner Feed to Calcined Solids Storage Facility II. (continued)

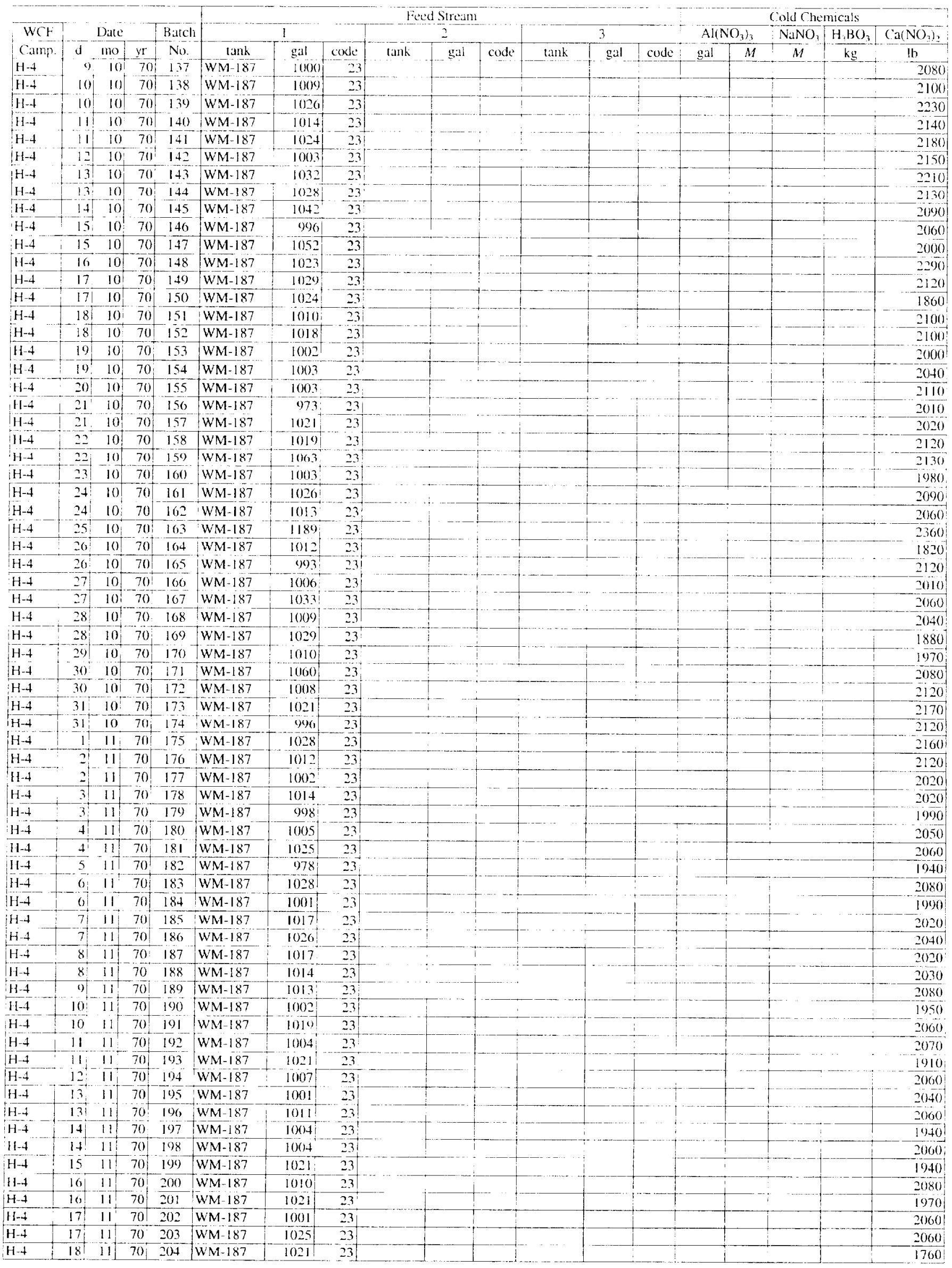


Table A2. Calciner Feed to Calcined Solids Storage Facility II. (continued)

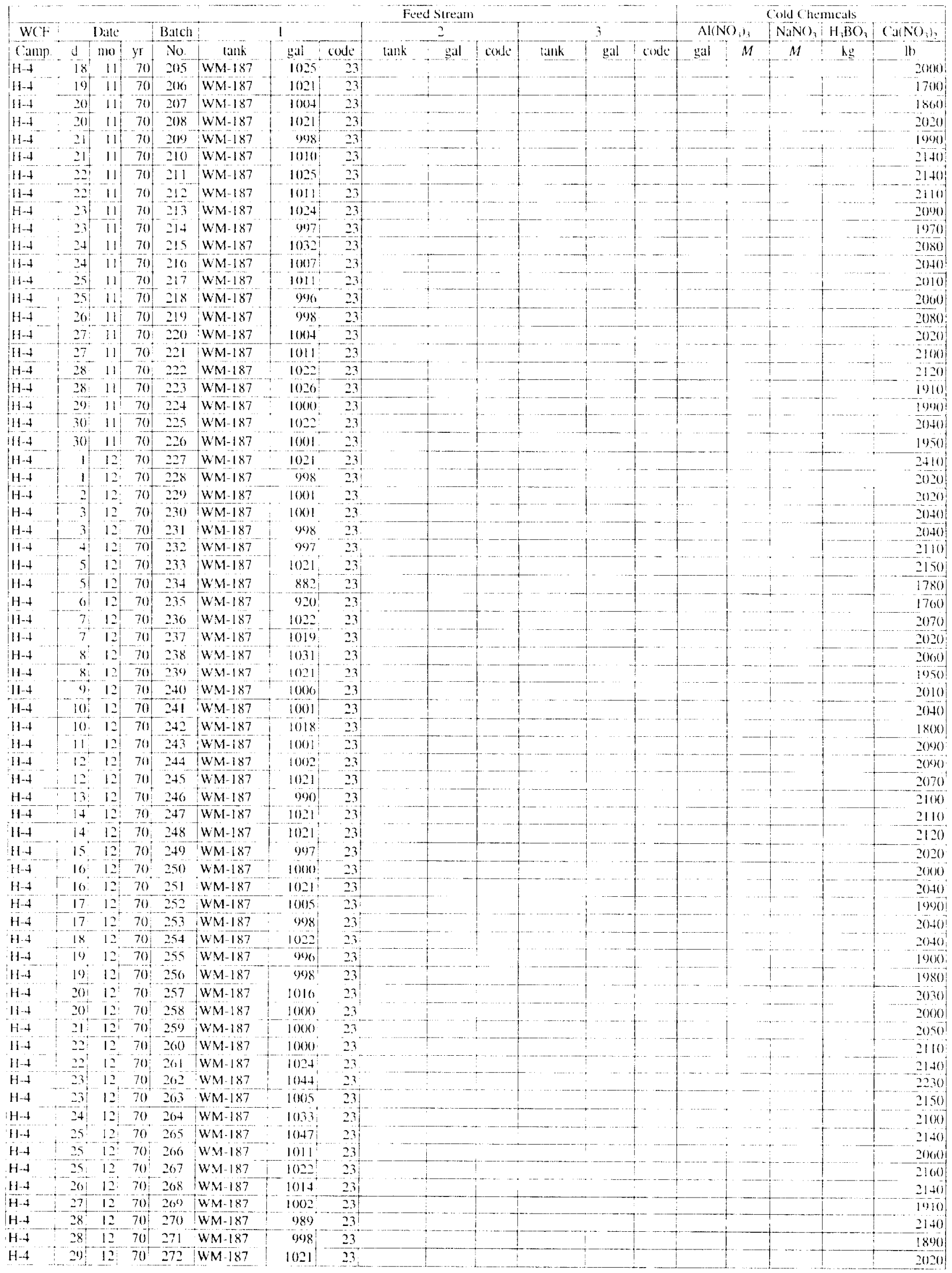


Table A2. Calciner Feed to Calcined Solids Storage Facility II. (continued)

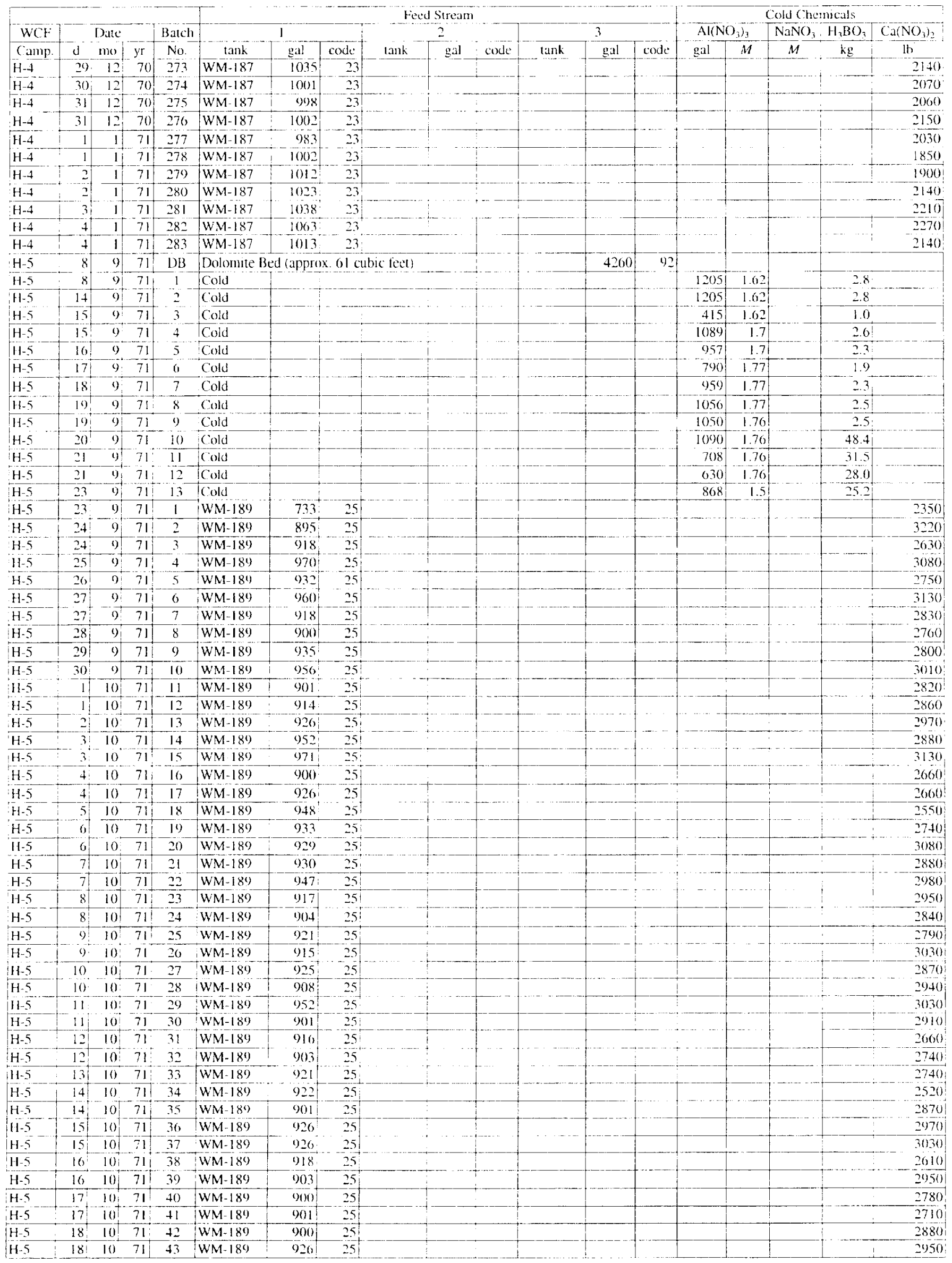


Table A2. Calciner Feed to Calcined Solids Storage Facility II. (continued)

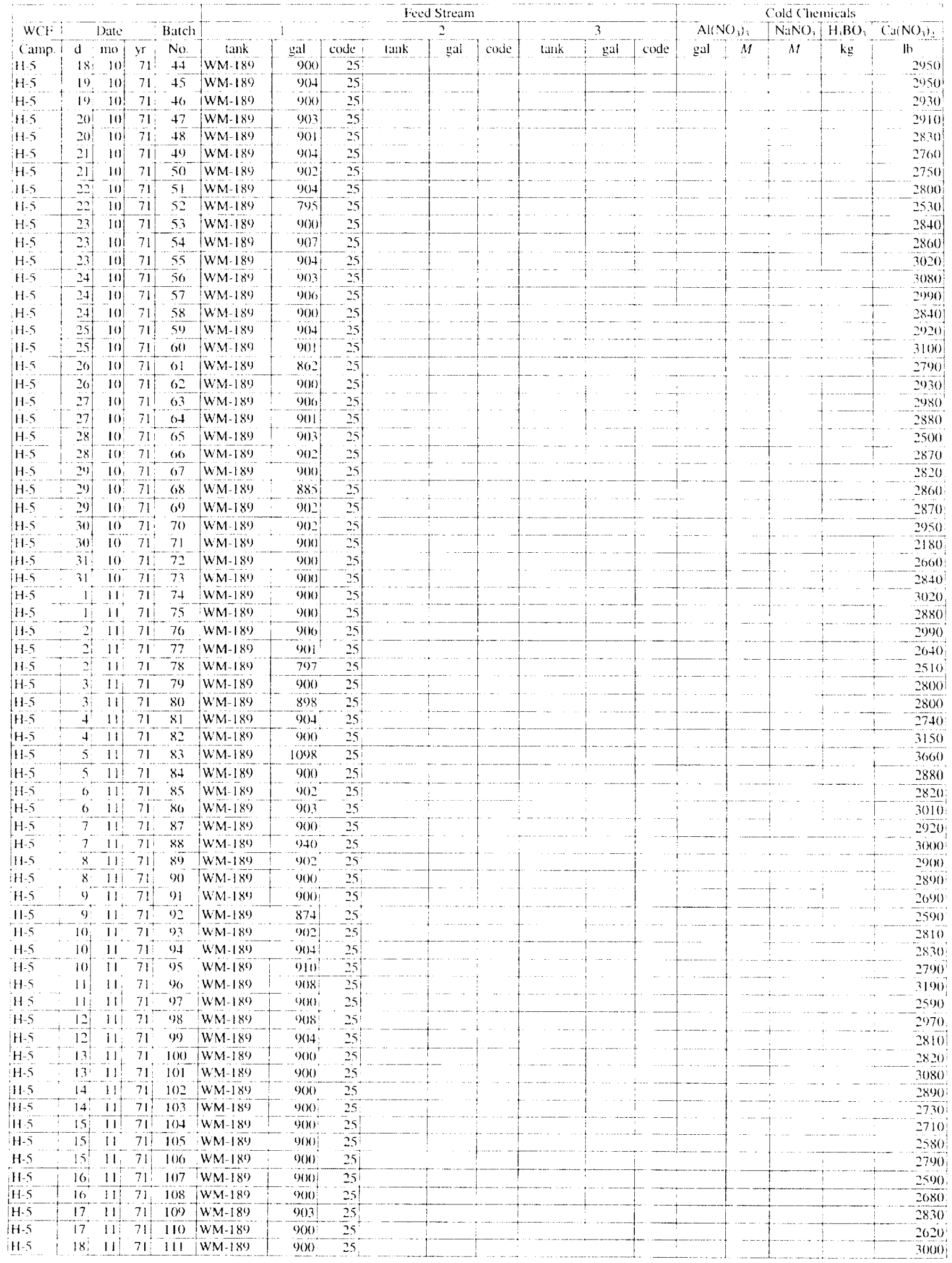


Table A2. Calciner Feed to Calcined Solids Storage Facility II. (continued)

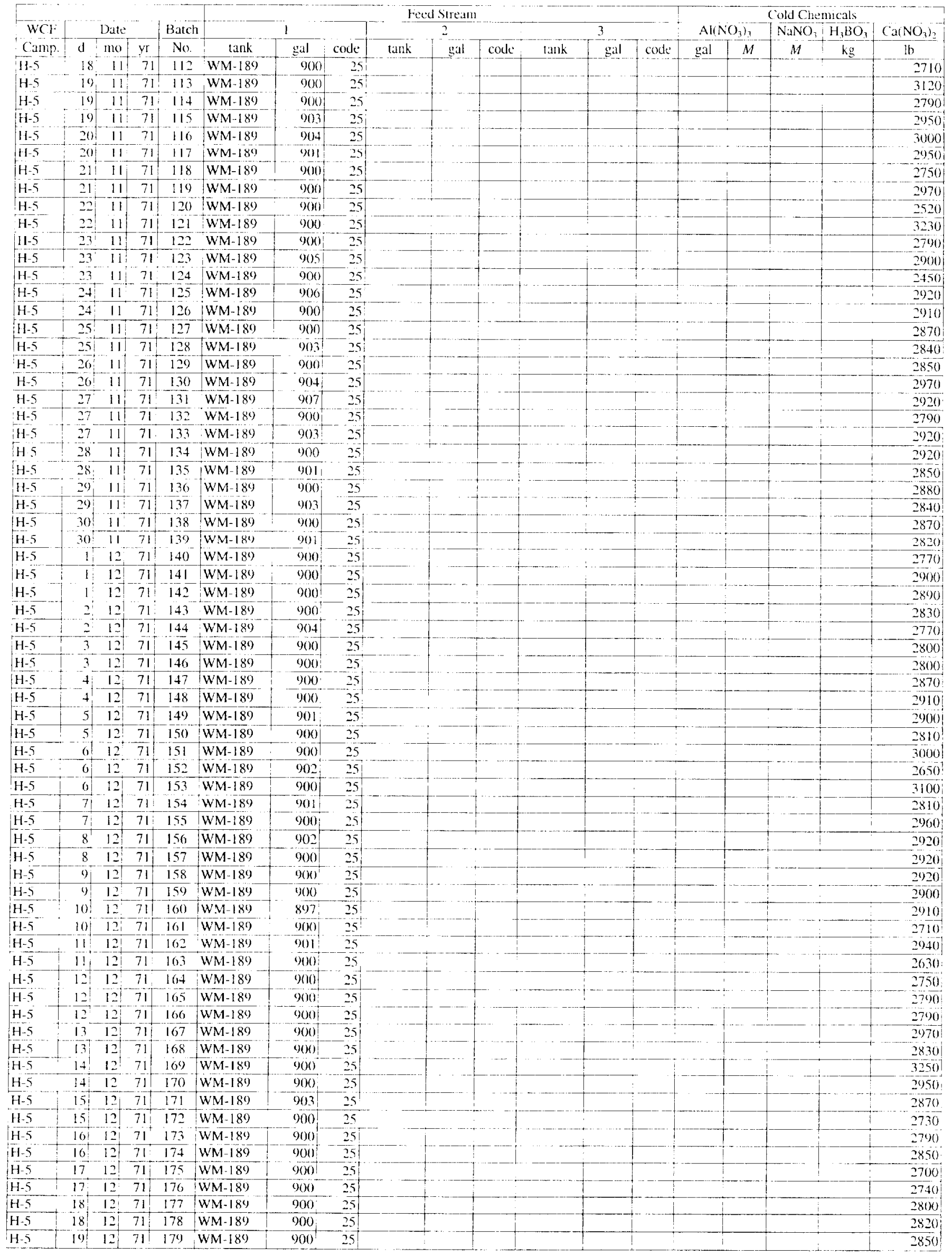


Table A2. Cakiner Feed to Calcined Solids Storage Facility II. (continued)

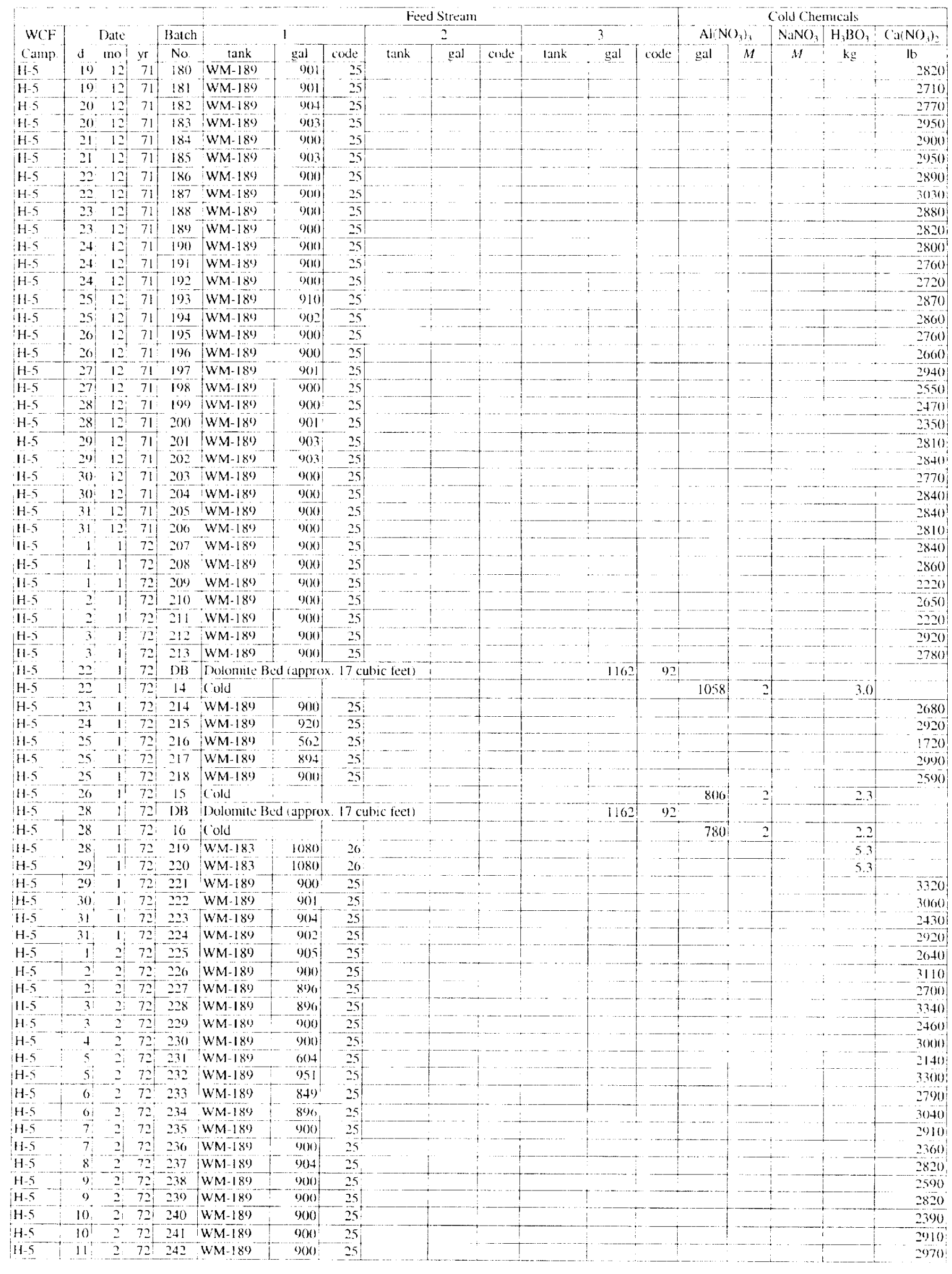


Table A2. Calciner Feed to Calcined Solids Storage Facility II. (continued)

\begin{tabular}{|c|c|c|c|c|c|c|c|c|c|c|c|c|c|c|c|c|c|c|}
\hline \multirow{2}{*}{ WCF } & \multirow{2}{*}{\multicolumn{2}{|c|}{ Date }} & & & \multicolumn{9}{|c|}{ Feed Stream } & \multicolumn{5}{|c|}{ Colt chemicals } \\
\hline & & & & Batch & & 1 & & & 2 & & & 3 & & & & $\mathrm{NaNO}$ & $\mathrm{H}_{3} \mathrm{BO}_{3}$ & $\mathrm{Ca}\left(\mathrm{NO}_{3}\right)_{2}$ \\
\hline Camp. & d & no & yr & No. & $\operatorname{tank}$ & gal & code & tank & gal & code & lank & gal & code & gal & $M$ & $M$ & $\mathrm{~kg}$ & $\mathrm{Ib}$ \\
\hline$H-5$ & 12 & 2 & 72 & 243 & WM-189 & $703 i$ & 25 & & & & & & & & & & & 2770 \\
\hline $11-5$ & 12 & 2 & 72 & 244 & WM-189 & 900 & 25 & & & & & & & & & & & 2720 \\
\hline $\mathrm{H}-5$ & 13 & 2 & 72 & 245 & WM-I 80 & $9(x)$ & 25 & & & & & & & & & & & 2400 \\
\hline H -5 & 14 & 2 & 721 & 246 & WM-189 & $9000^{\dagger}$ & 25 & & & & & & & & & & & 2870 \\
\hline $\mathrm{H}-5$ & 15 & 2 & 72 & 247 & WM-189 & 917 & 25 & & & & & & & & & & & 2590 \\
\hline H.5 & 15 & 2 & 72 & 248 & WM- 189 & 903 & 25 & & & & & & & & & & & 2720 \\
\hline $\mathrm{H} . \mathrm{S}$ & 16 & 2 & 72 & 249 & WM-189 & 900 & 25 & & & & & & & & & & & 2040 \\
\hline
\end{tabular}


Table A3. Calciner Feed to Calcined Solids Storage Facility III.

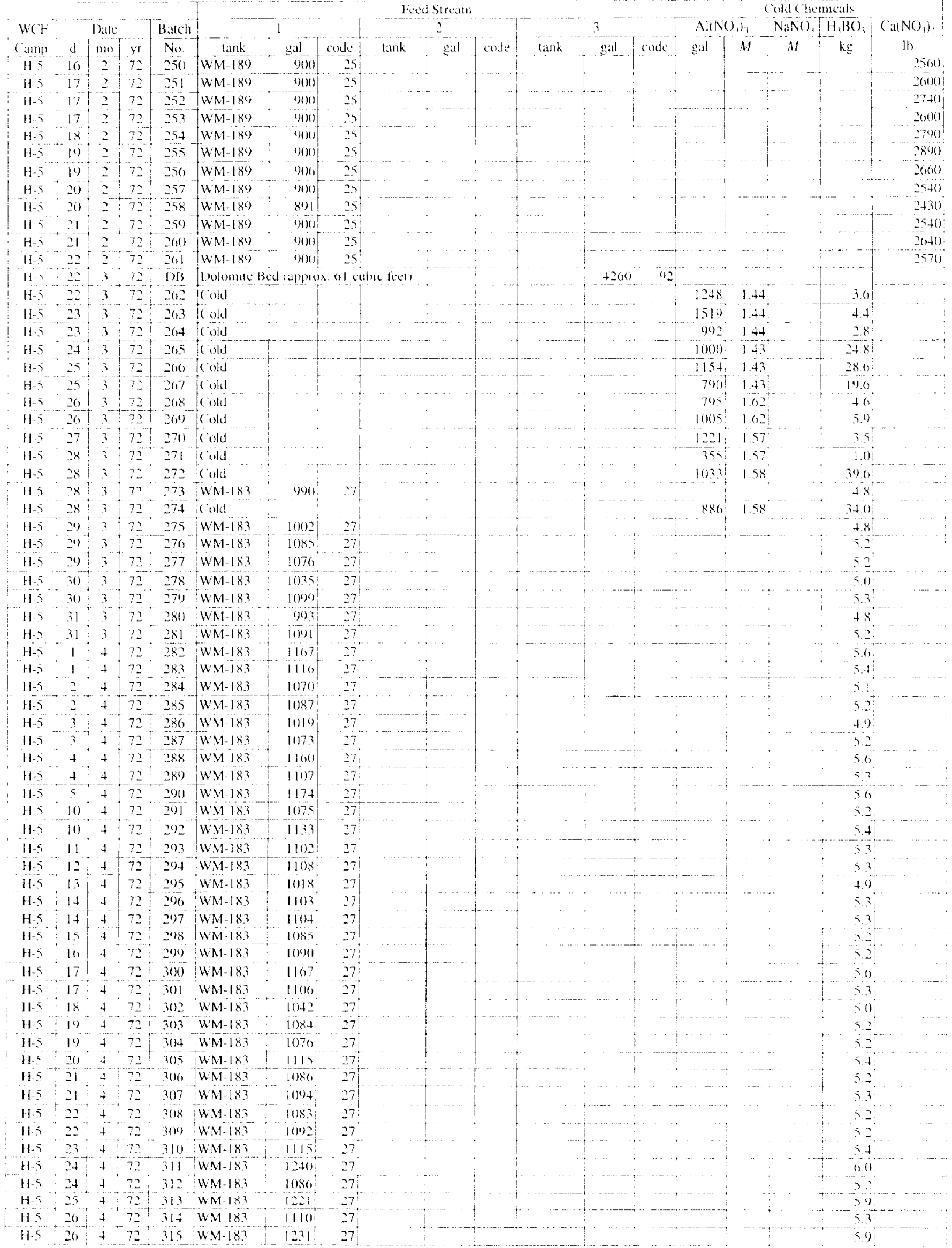


Table A3. Calciner Feed to Calcined Solids Storage Facility III. (continued)

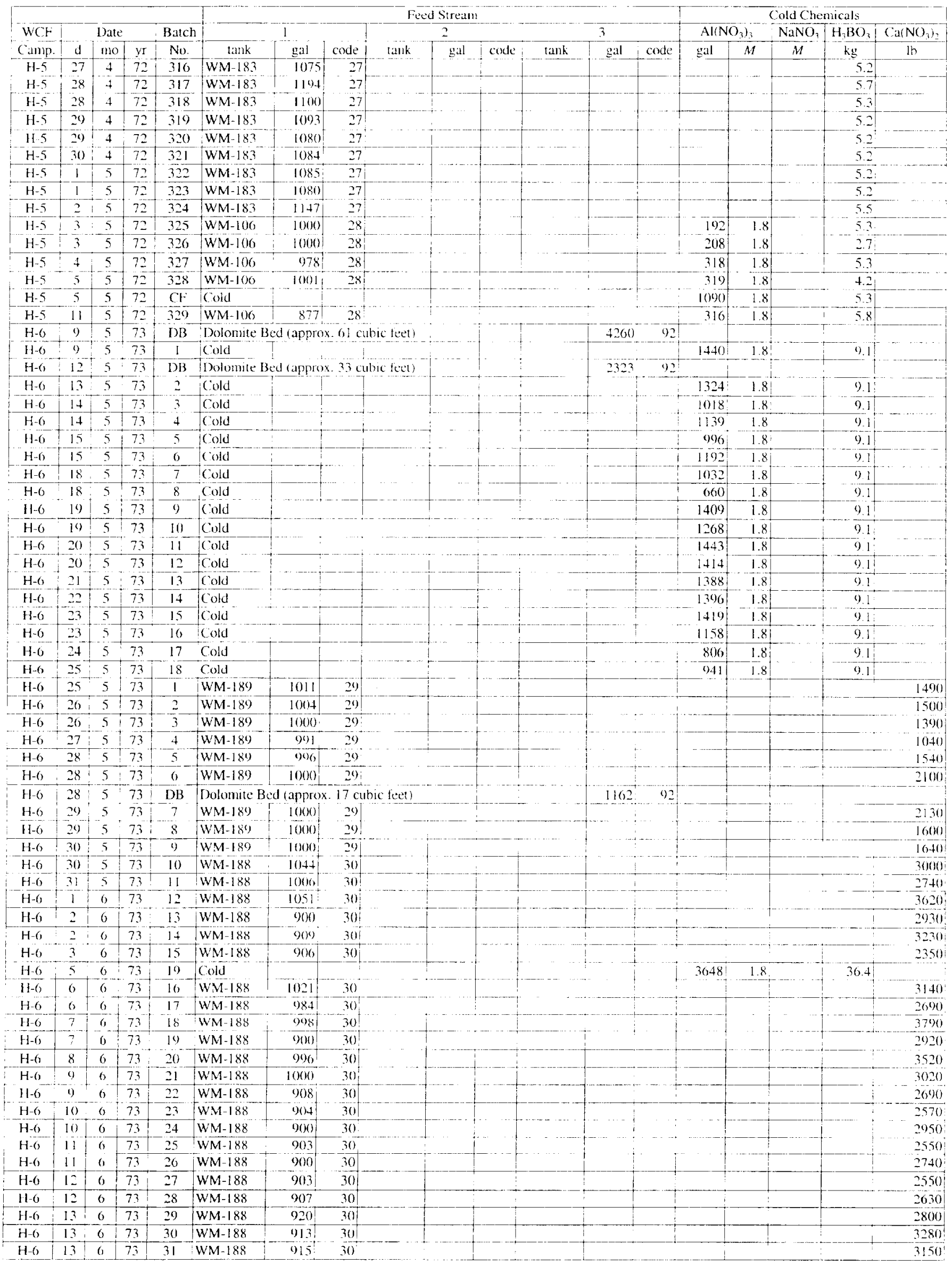


Table A3. Calciner Feed to Calcined Solids Storage Facility III. (continued)

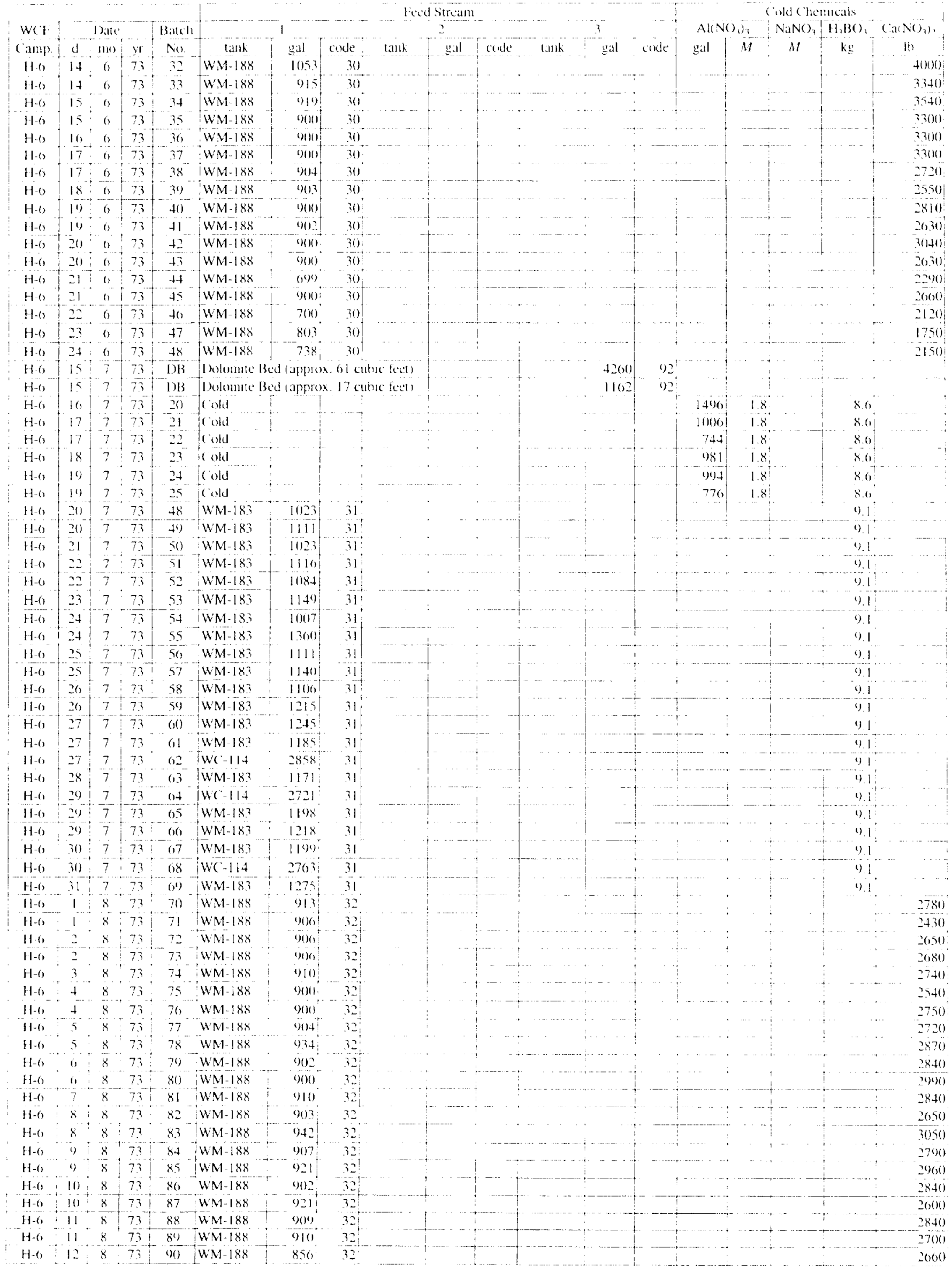


Table A3. Calciner Feed to Calcined Solids Storage Facility III. (continued)

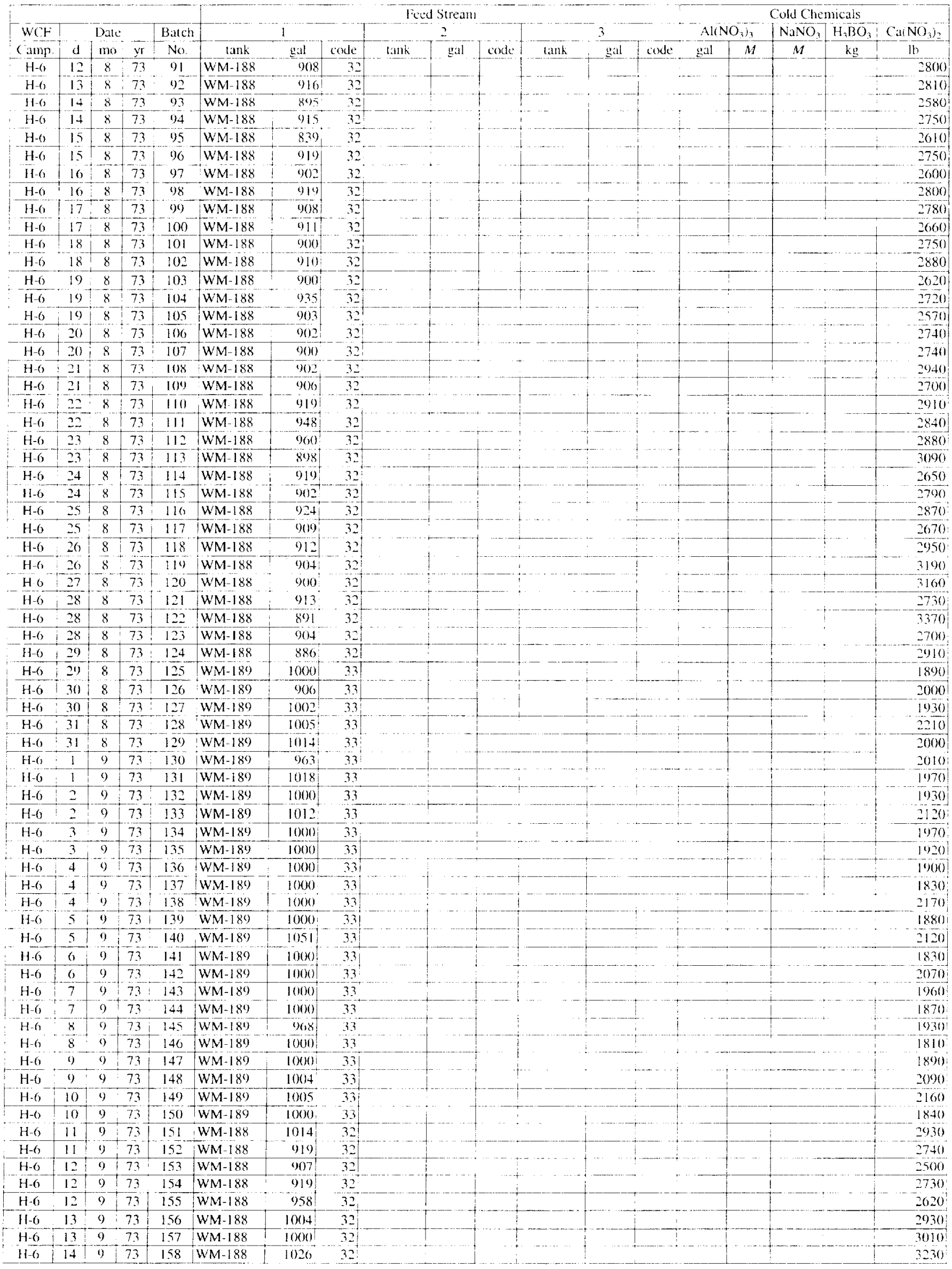


Table A3. Calciner Feed to Cakined Solids Storage Facility III. (continued)

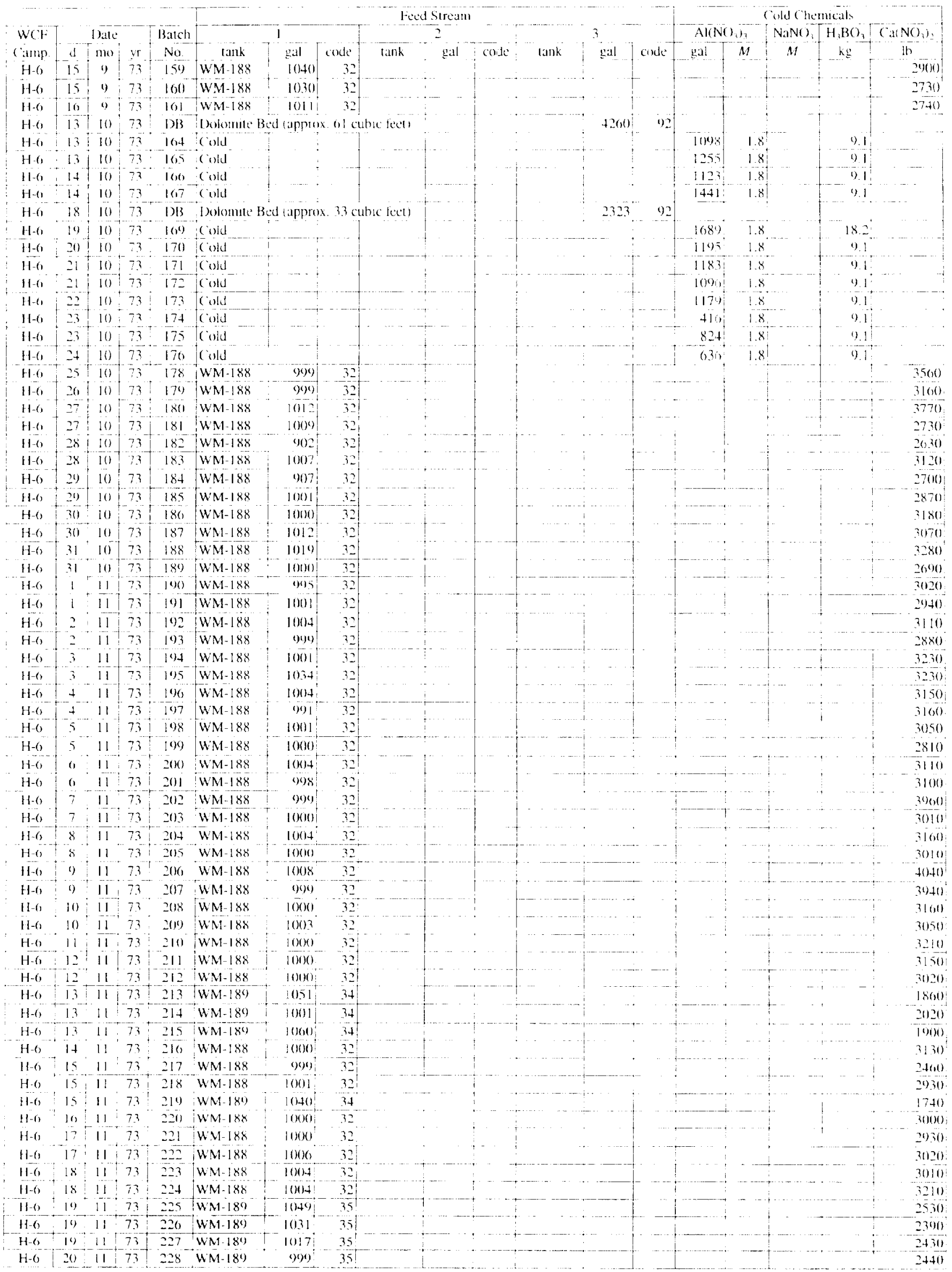


Table A3. Calciner Feed to Calcined Solids Storage Facility III. (continued)

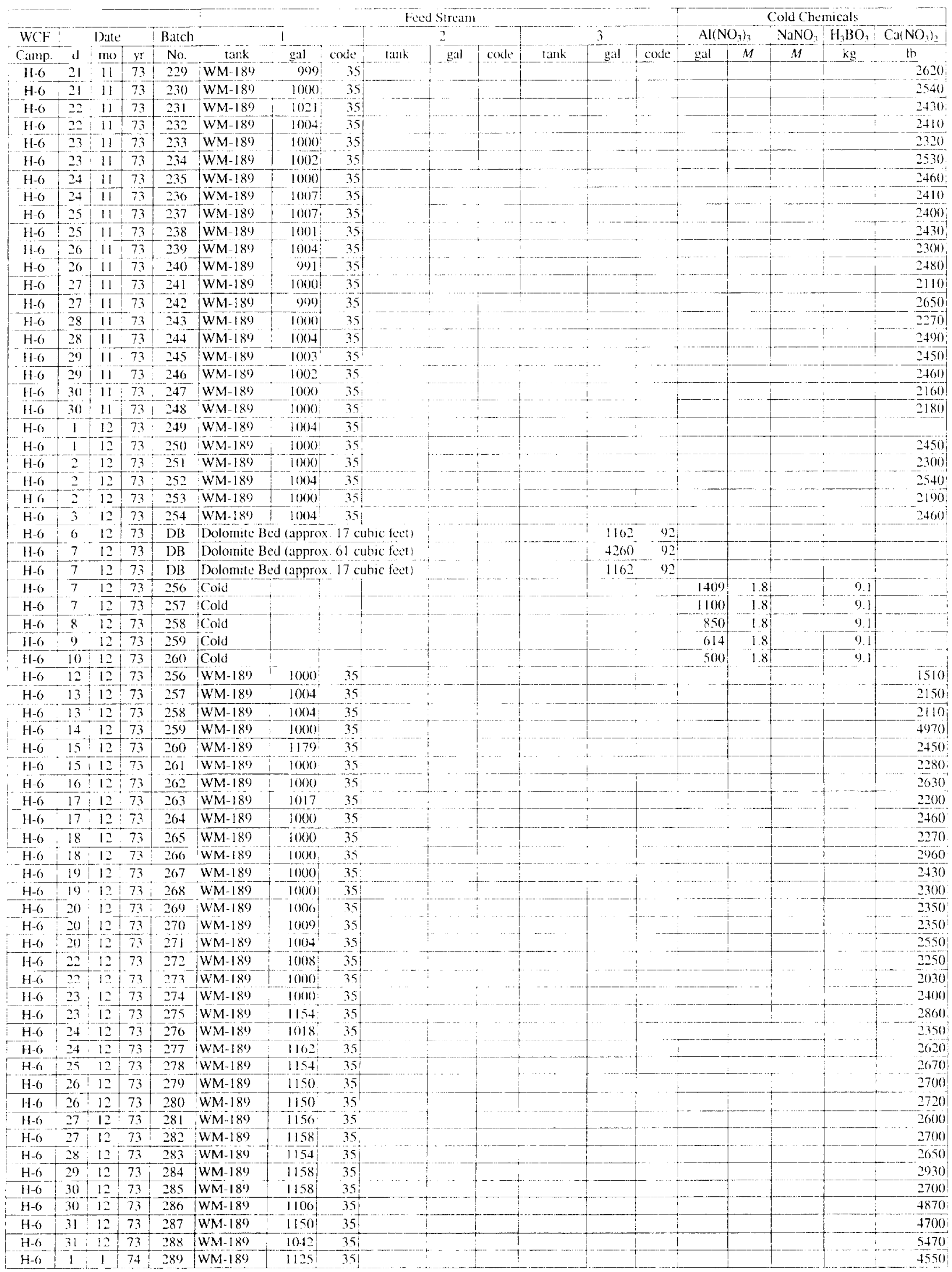


Table A3. Calciner Feed to Calcined Solids Storage Facility III. (continued)

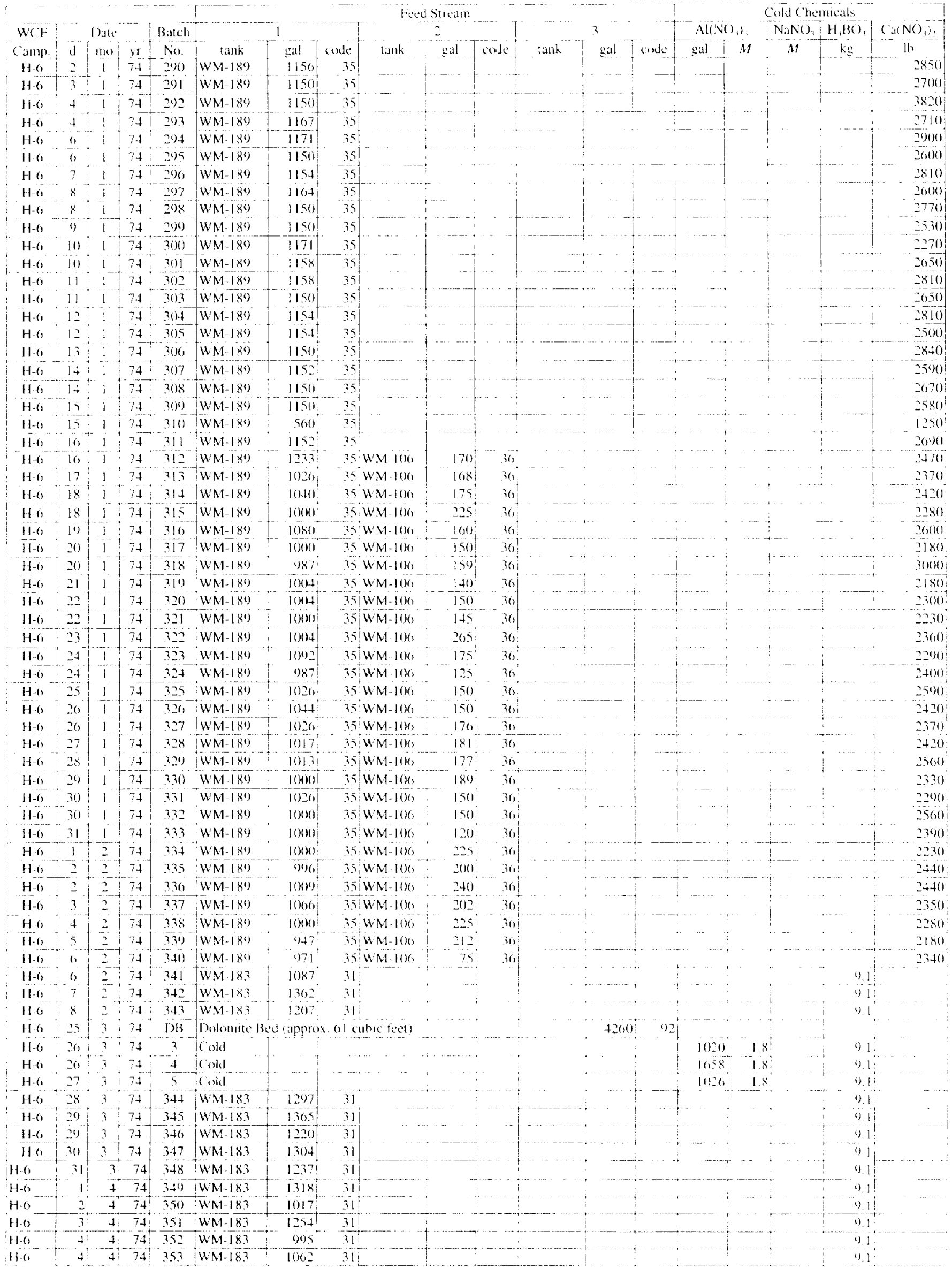


Table A3. Calciner Feed to Calcined Solids Storage Facility III. (continued)

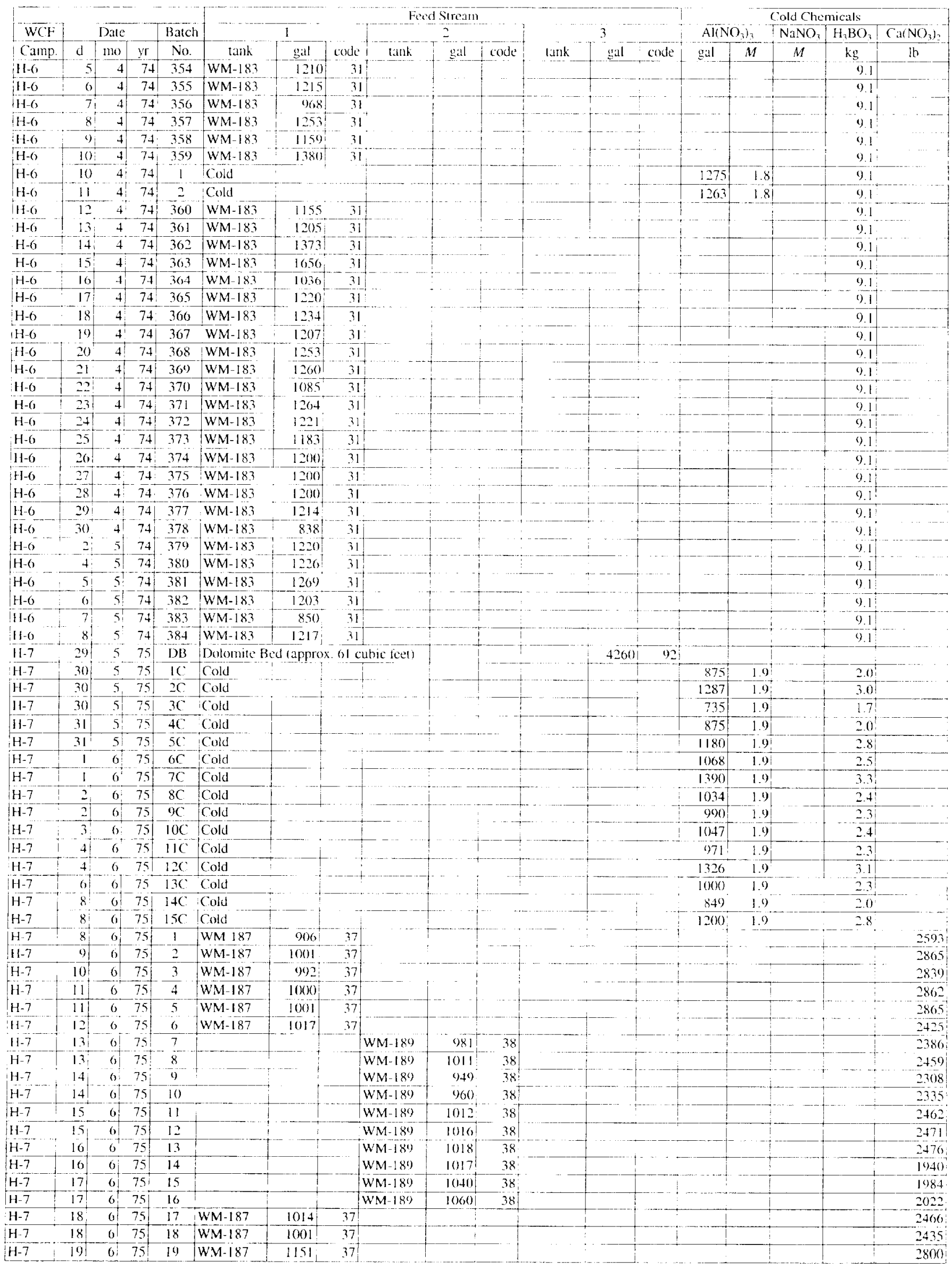


Table A3. Calciner Feed to Calcined Solids Storage Facility III. (continued)

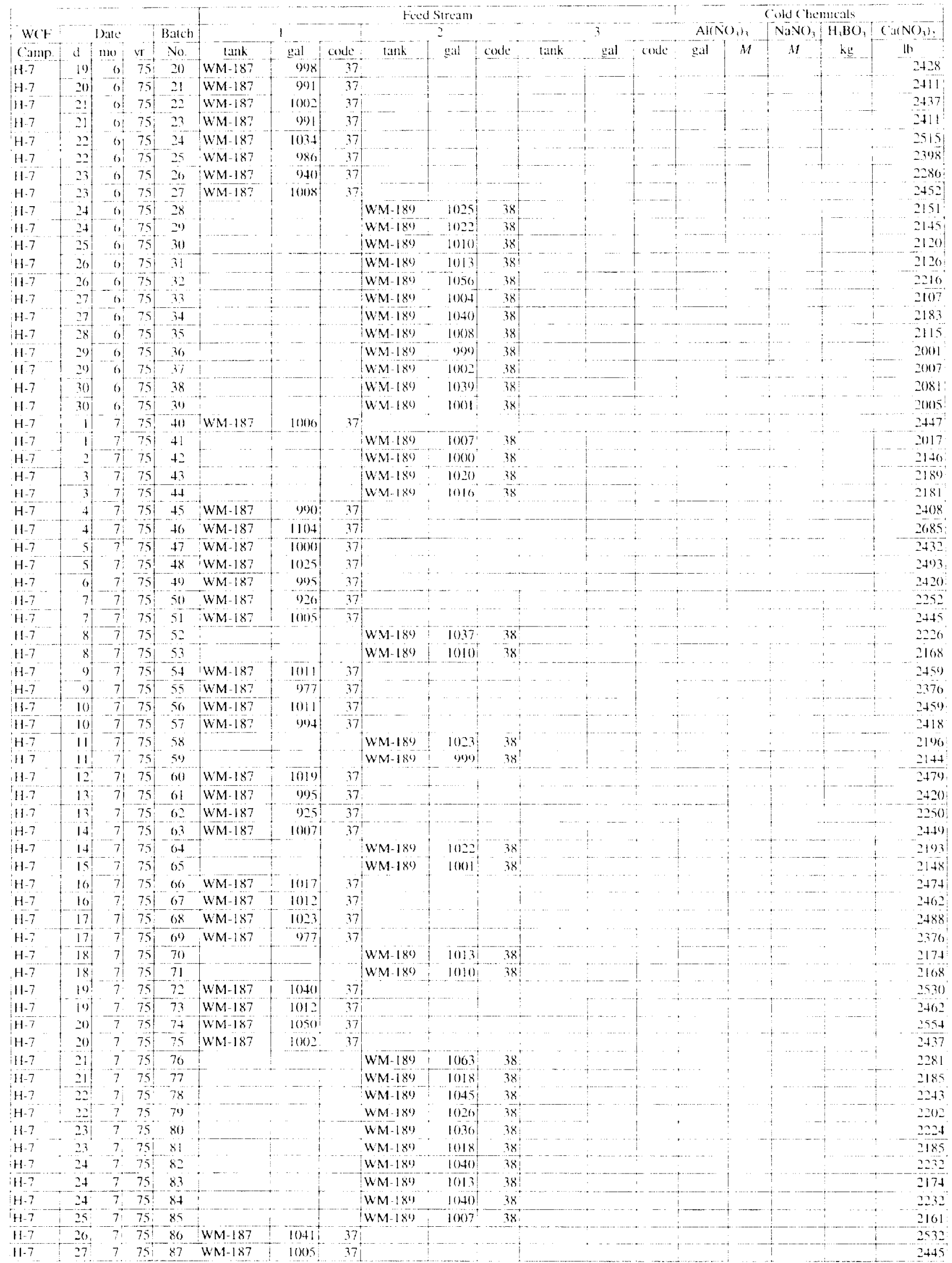


Table A3. Calciner Feed to Calcined Solids Storage Facility IIl. (continued)

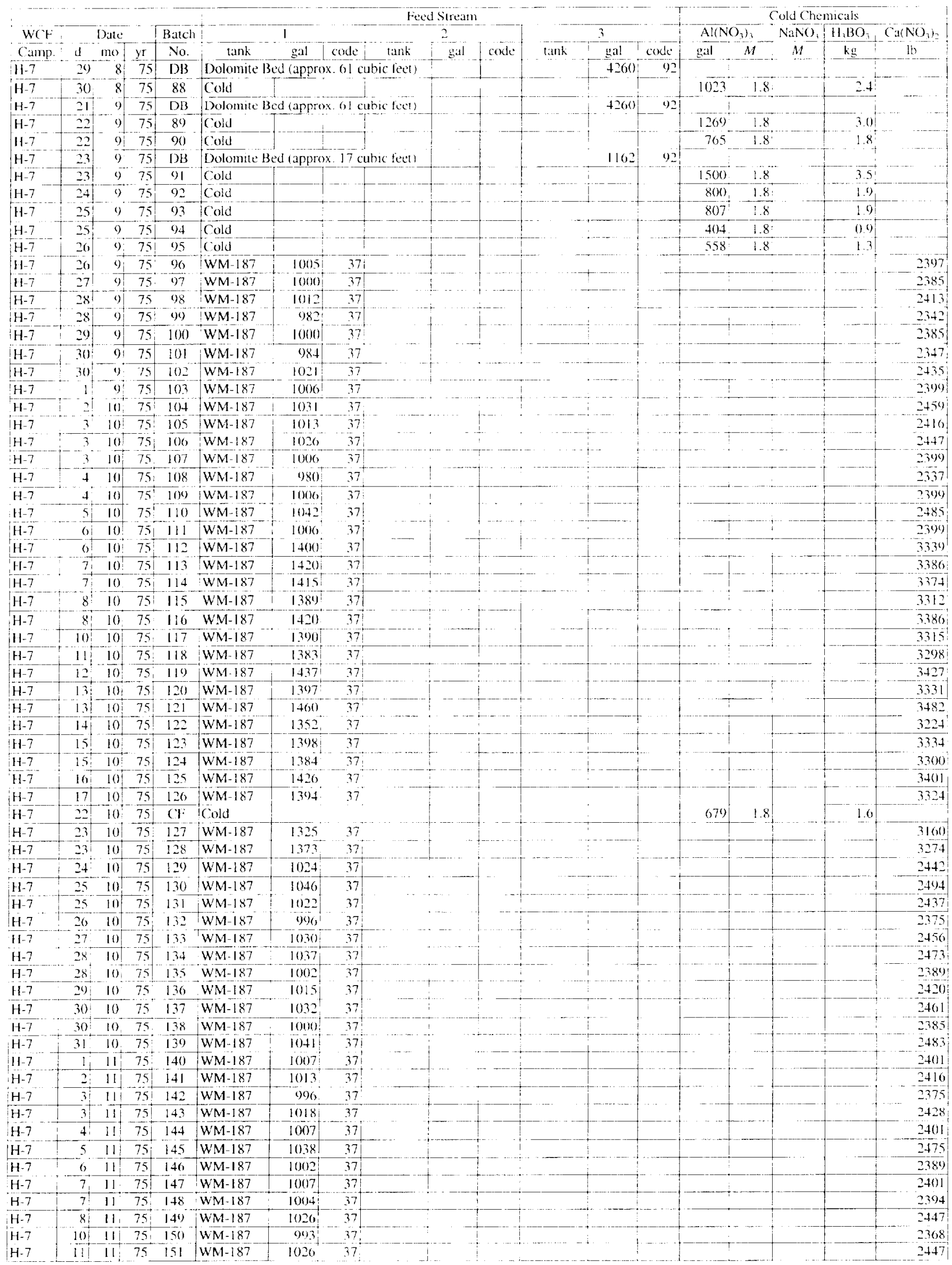


Table A3. Calciner Feed to Calcined Solids Storage Facility III. (continued)

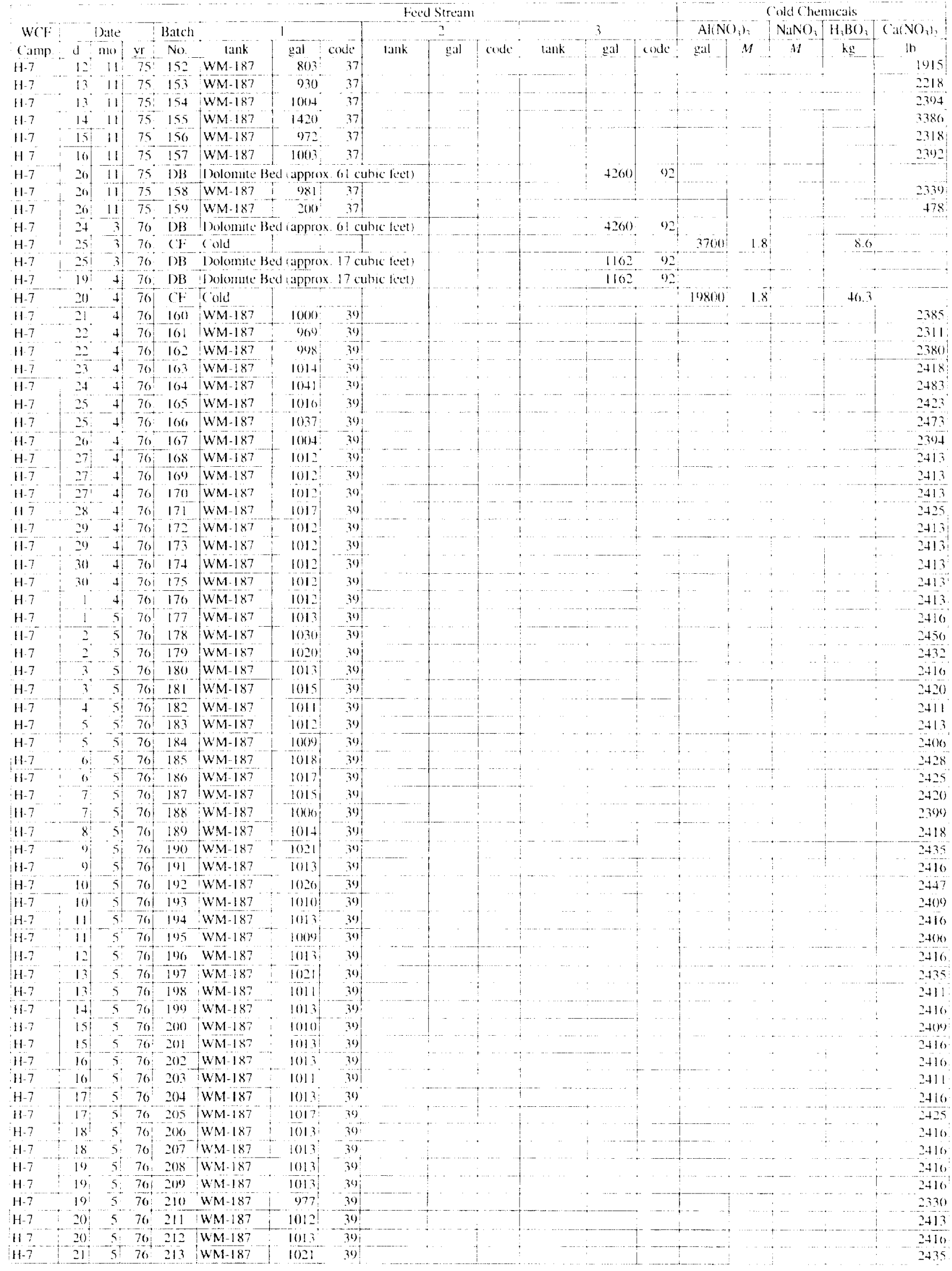


Table A3. Calciner Feed to Calcined Solids Storage Facility III. (continued)

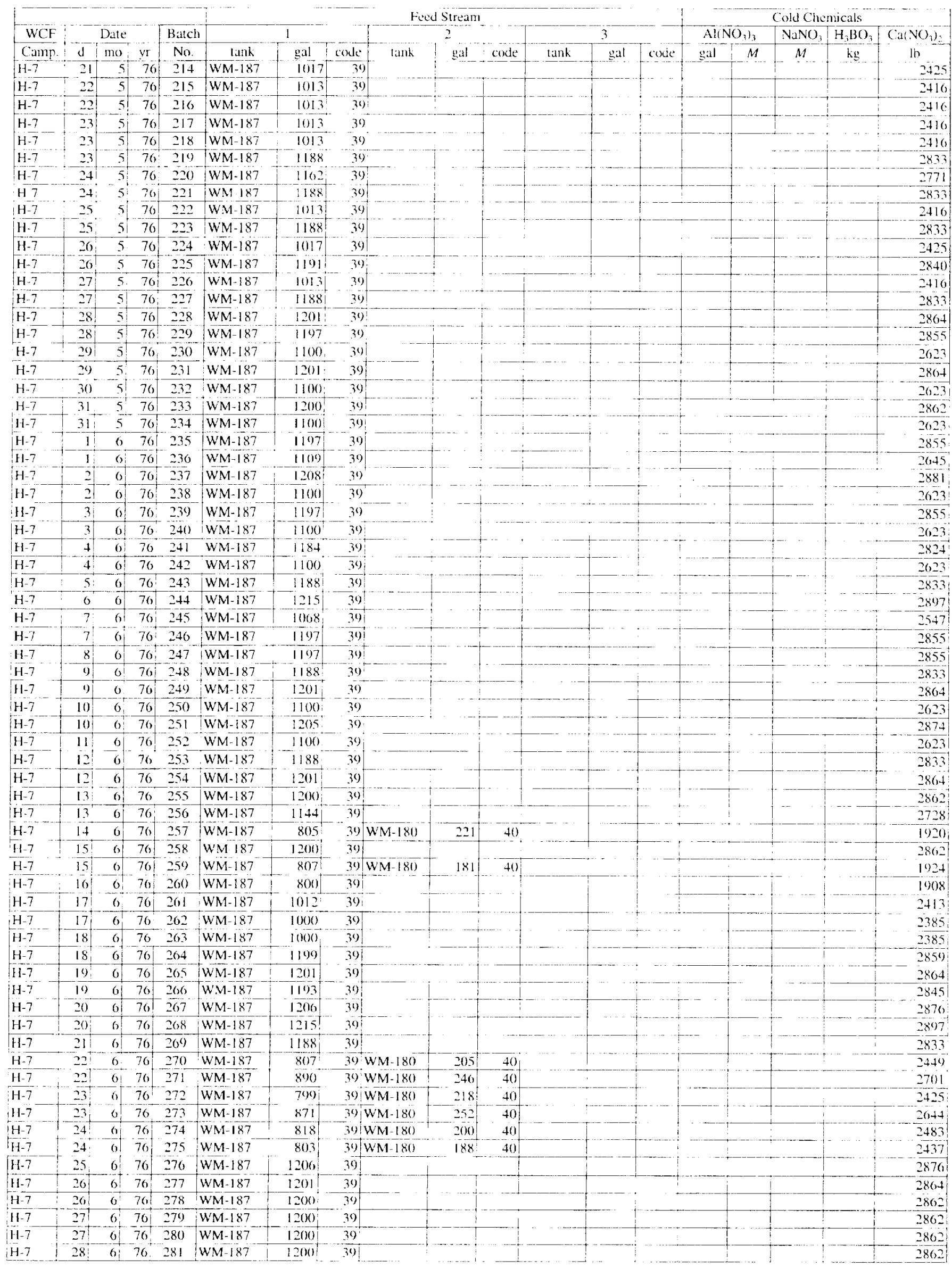


Table A3. Calciner Feed to Calcined Solids Storage Facility III. (continued)

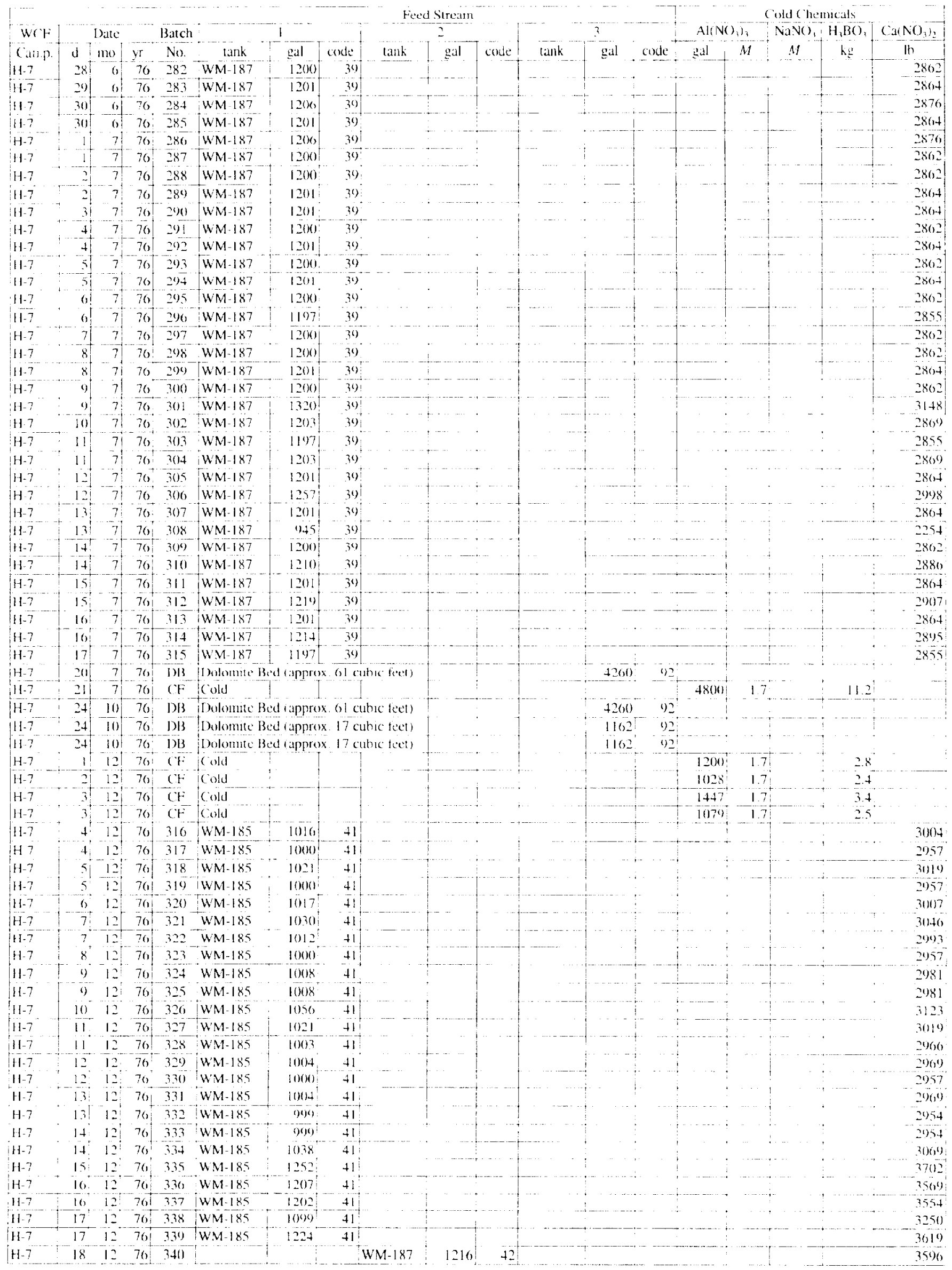


Table A3. Calciner Feed to Calcined Solids Storage Facility III. (continued)

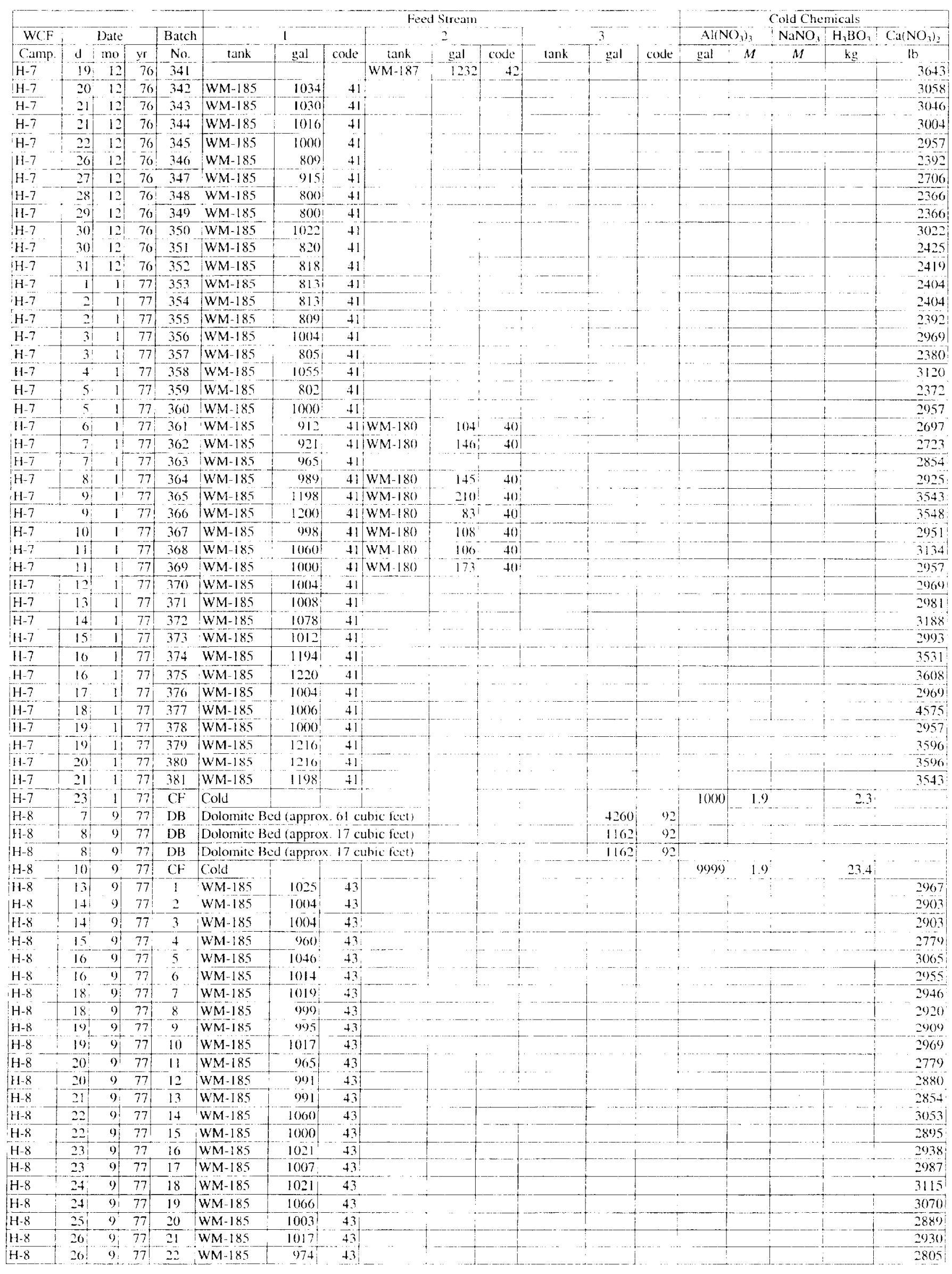


Table A3. Calciner Feed to Calcined Solids Storage Facility III. (continued)

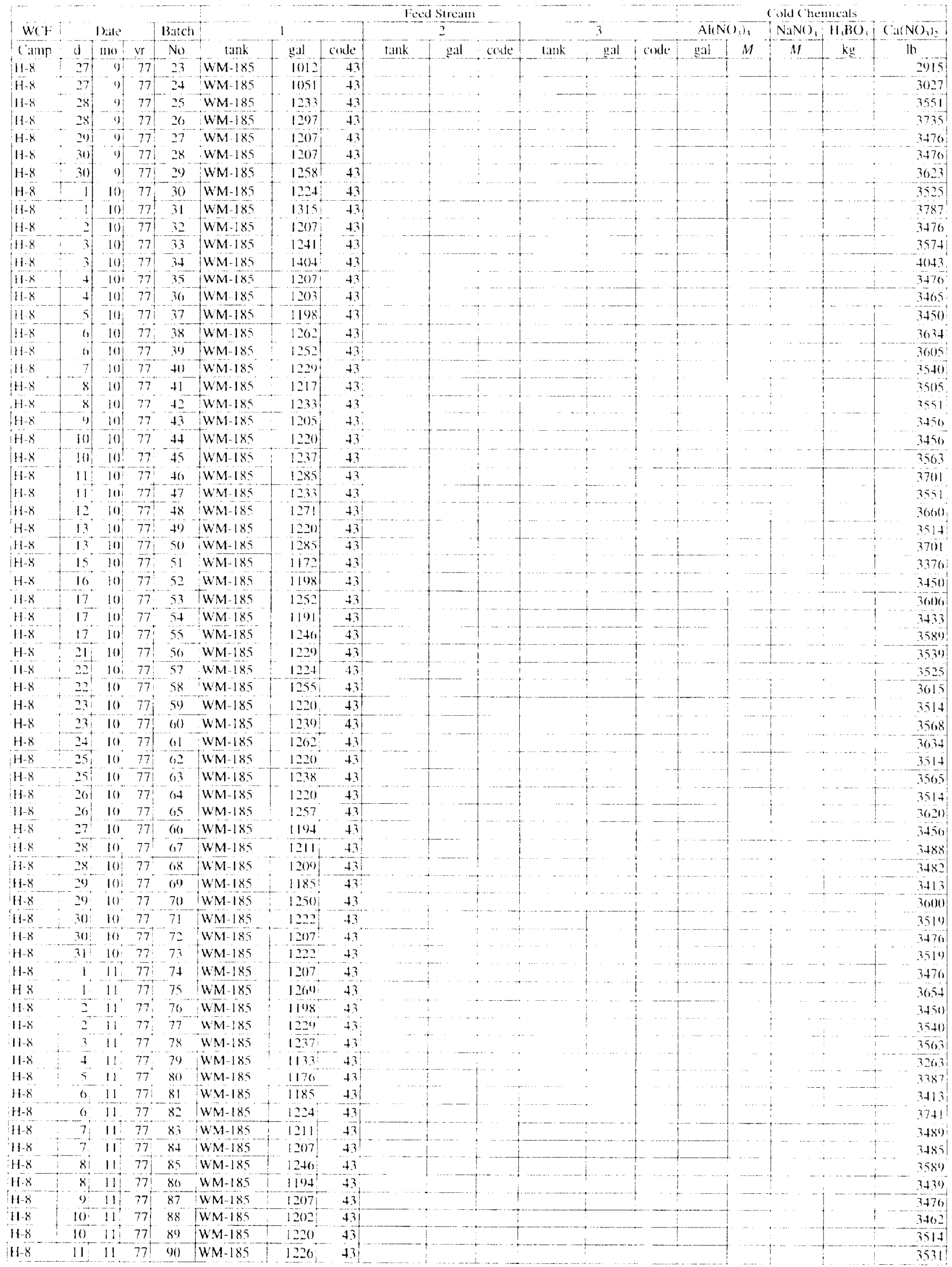


Table A3. Calciner Feed to Calcined Solids Storage Facility III. (continued)

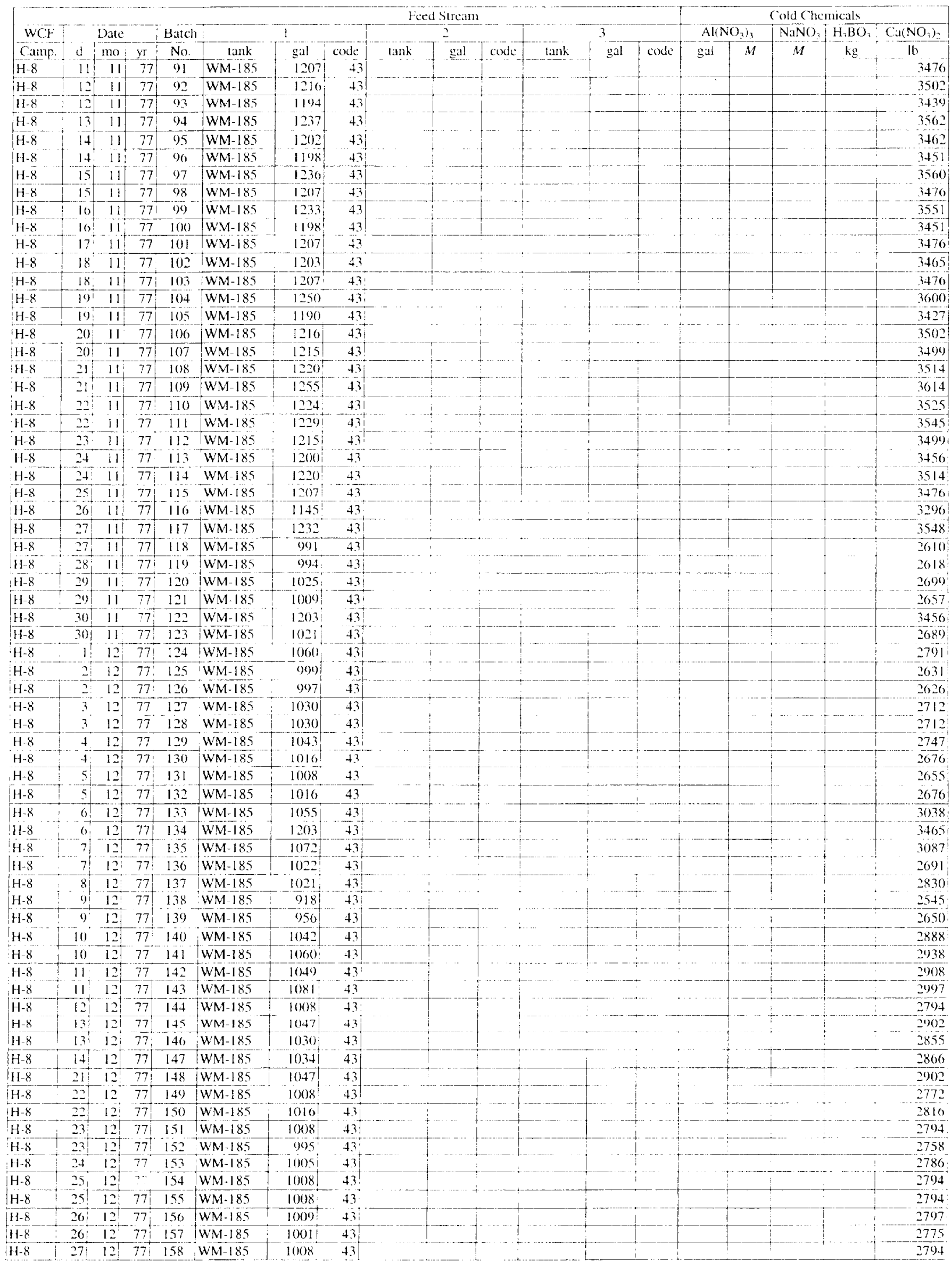


Table A3. Calciner Feed to Calcined Solids Storage Facility III. (continued)

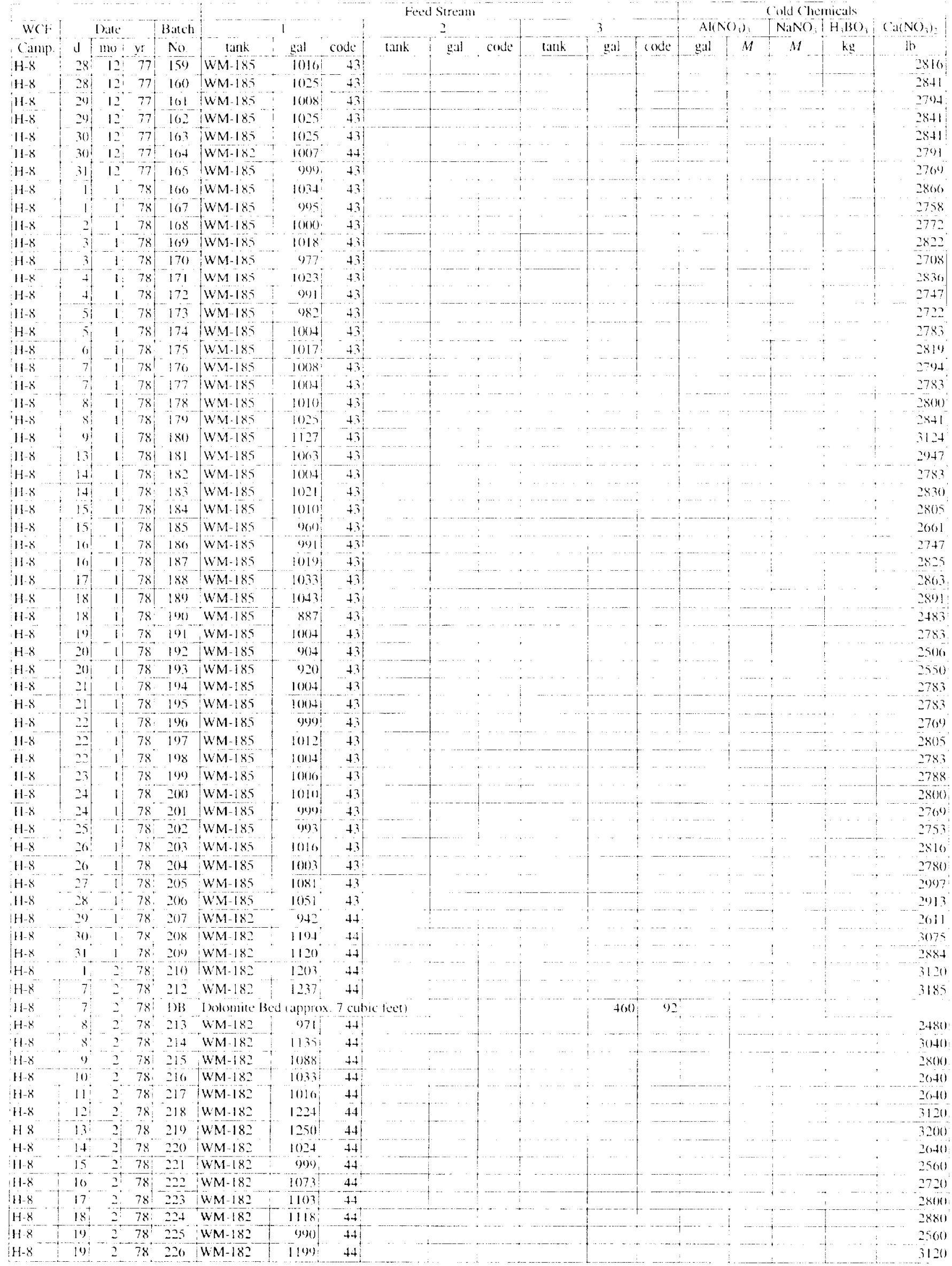


Table A3. Calciner Feed to Calcined Solids Storage Facility III. (continued)

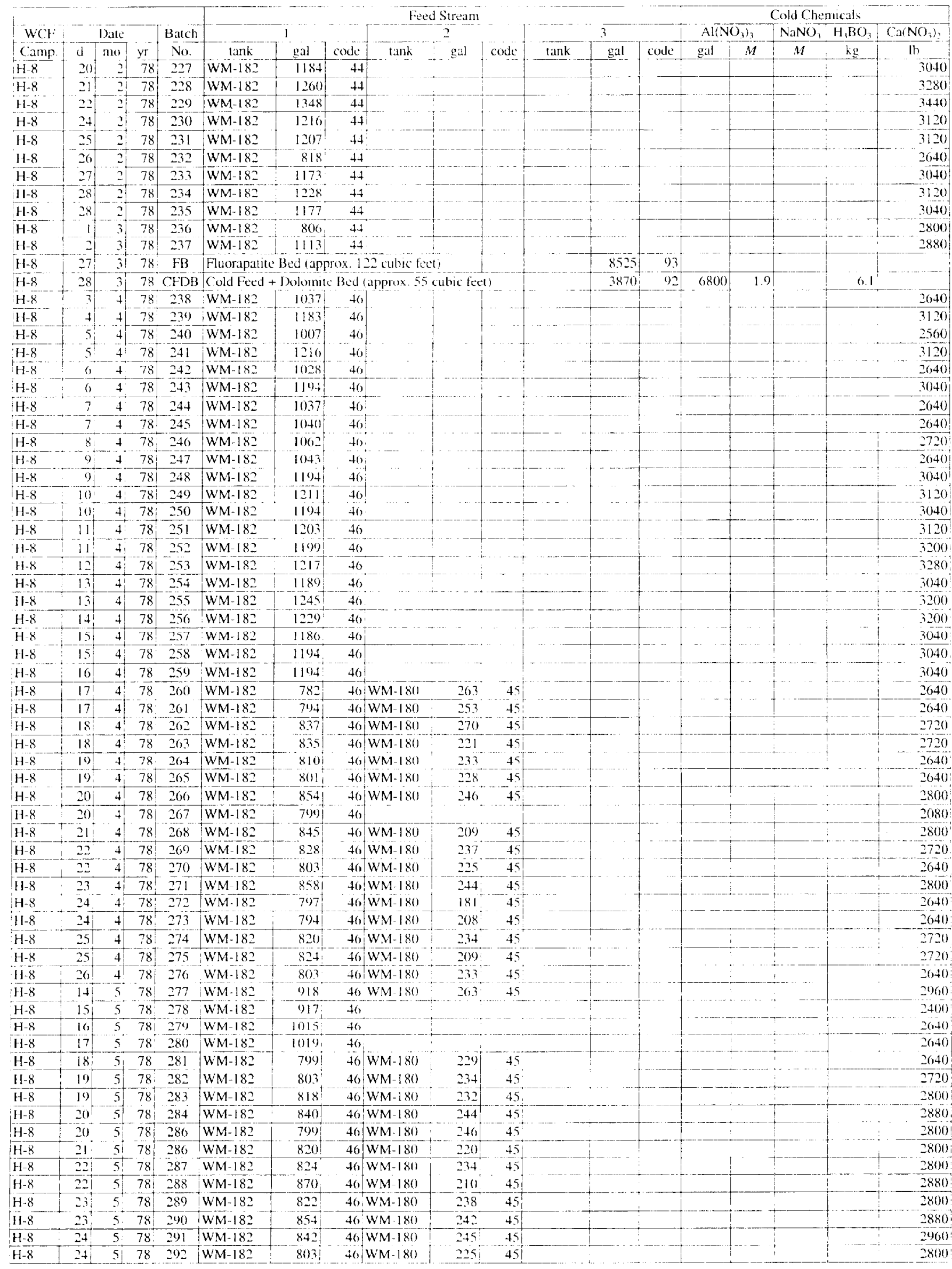


Table A3. Calciner Feed to Calcined Solids Storage Facility III. (continued)

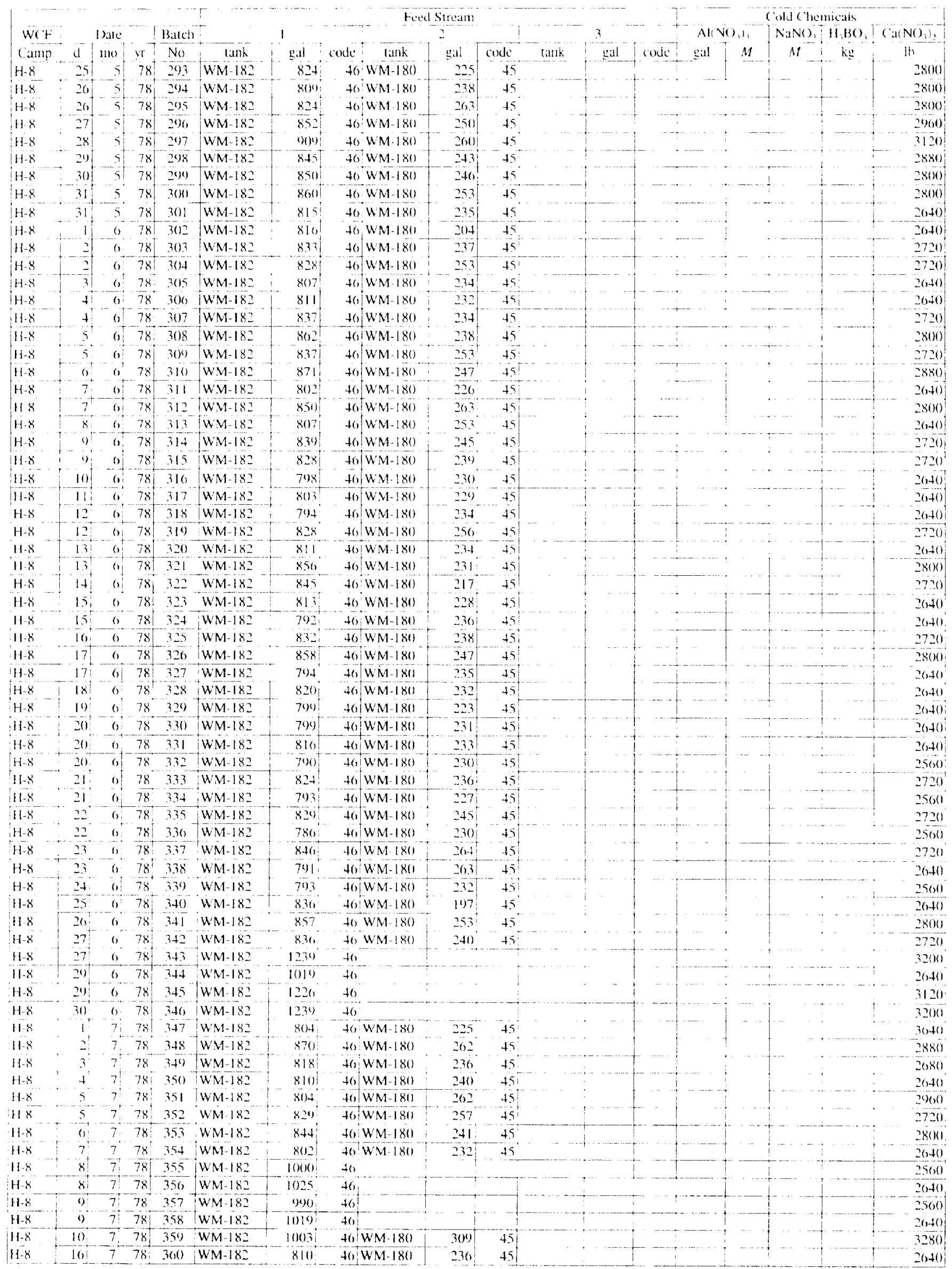


Table A3. Calciner Feed to Calcined Solids Storage Facility III. (continued)

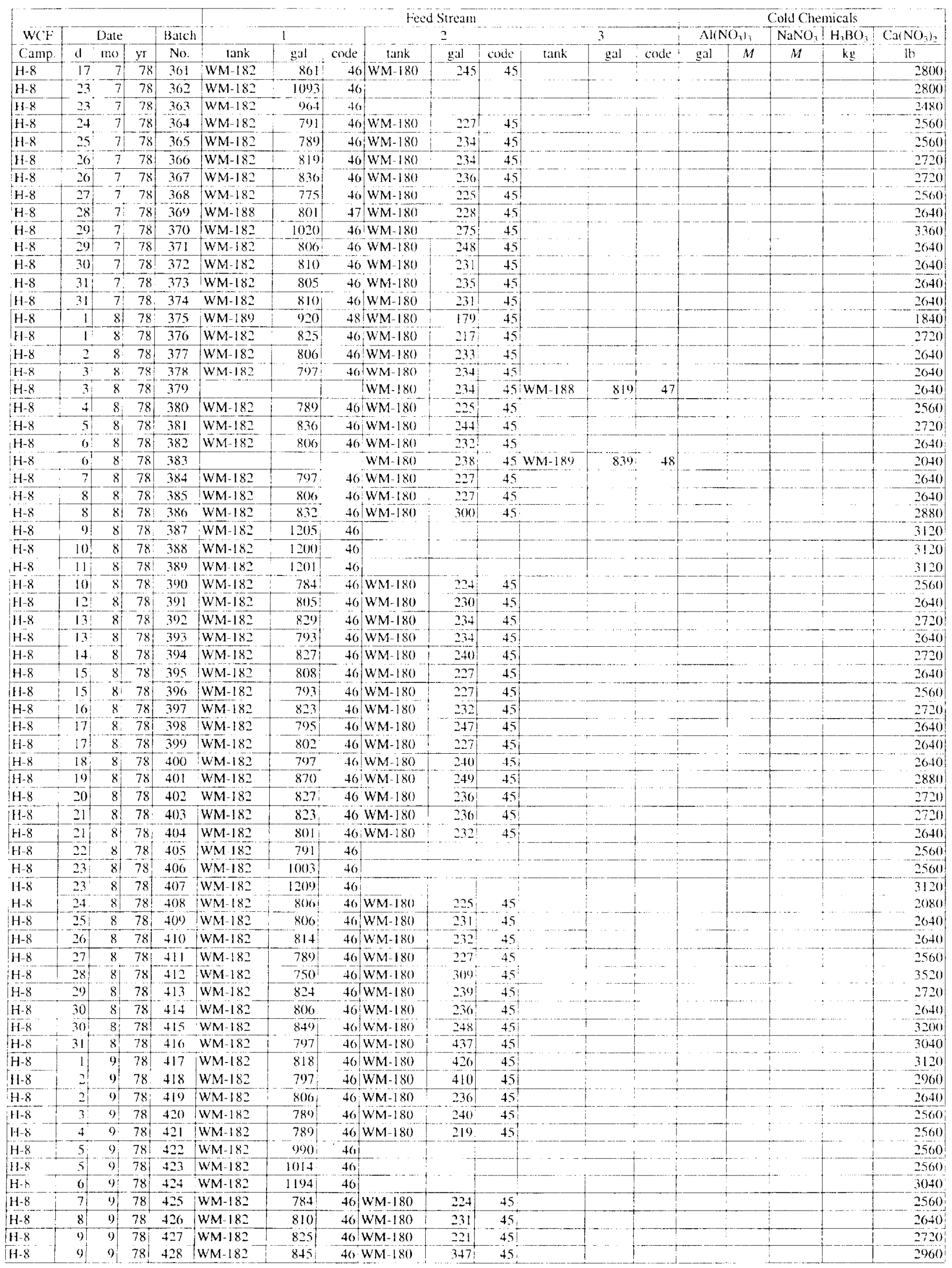


Table A3. Calciner Feed to Calcined Solids Storage Facility III. (continued)

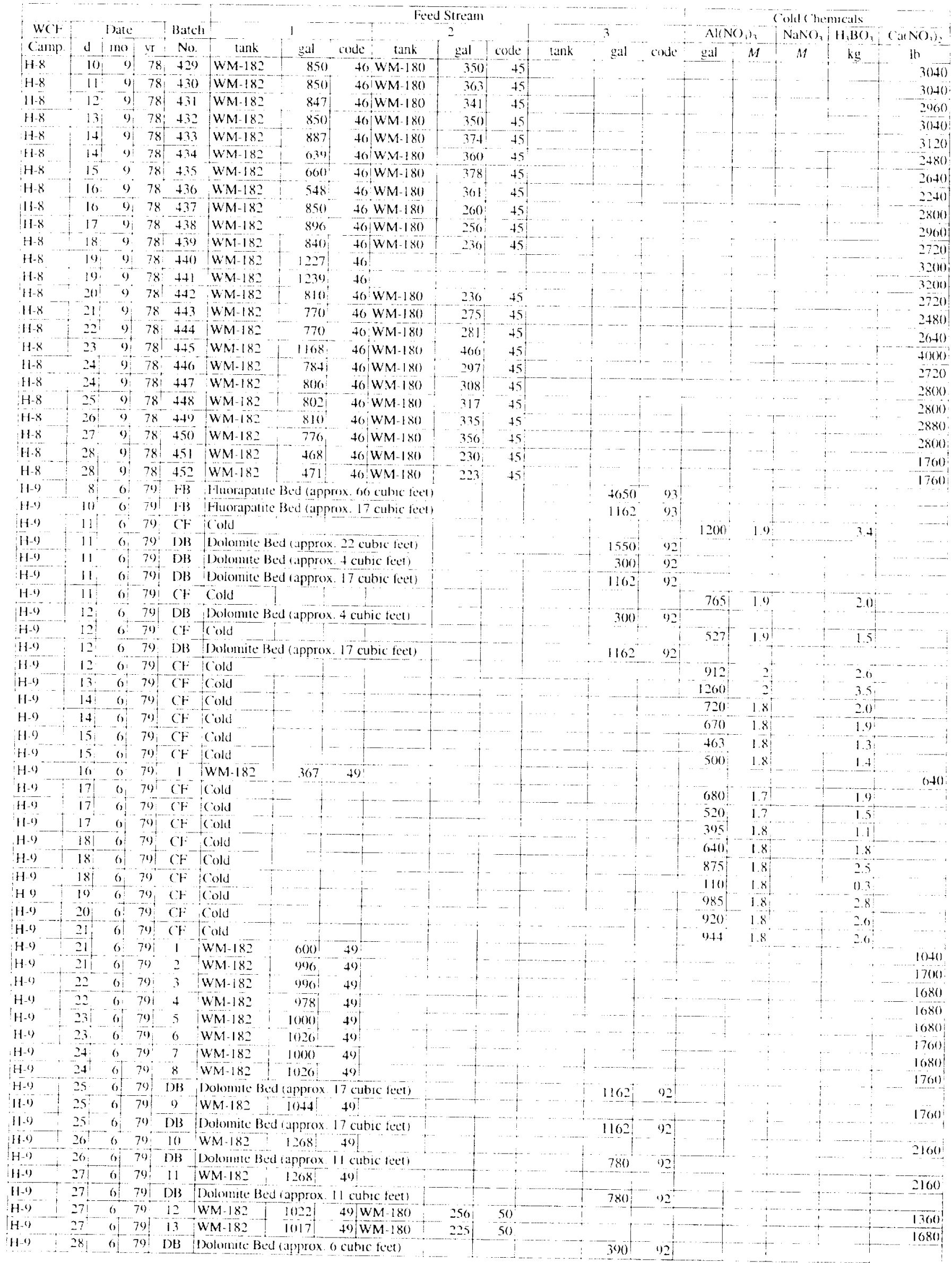


Table A3. Cakiner Feed to Calcined Solids Storage Facility III. (continued)

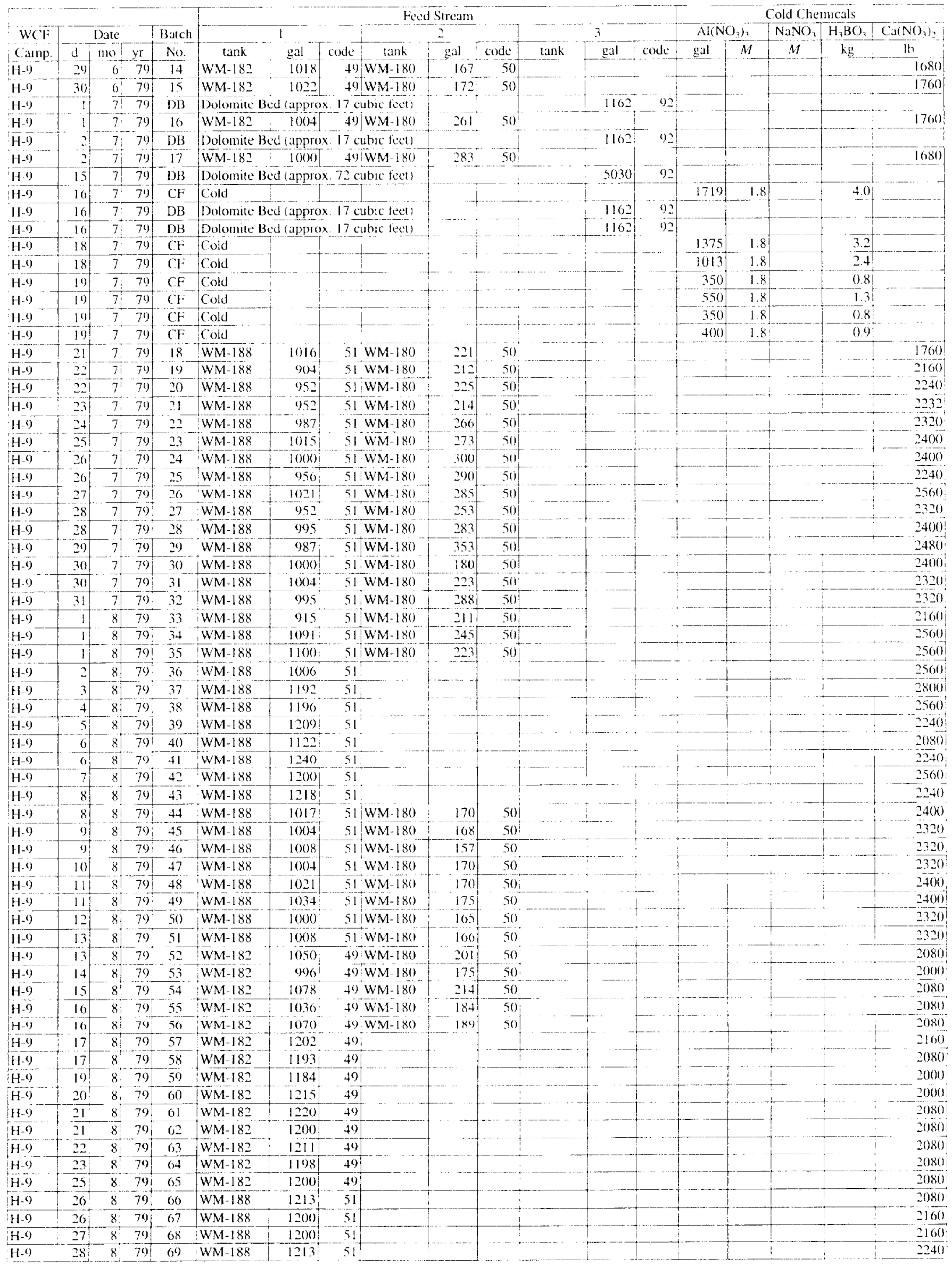


Table A3. Calciner Feed to Calcined Solids Storage Facility III. (continued)

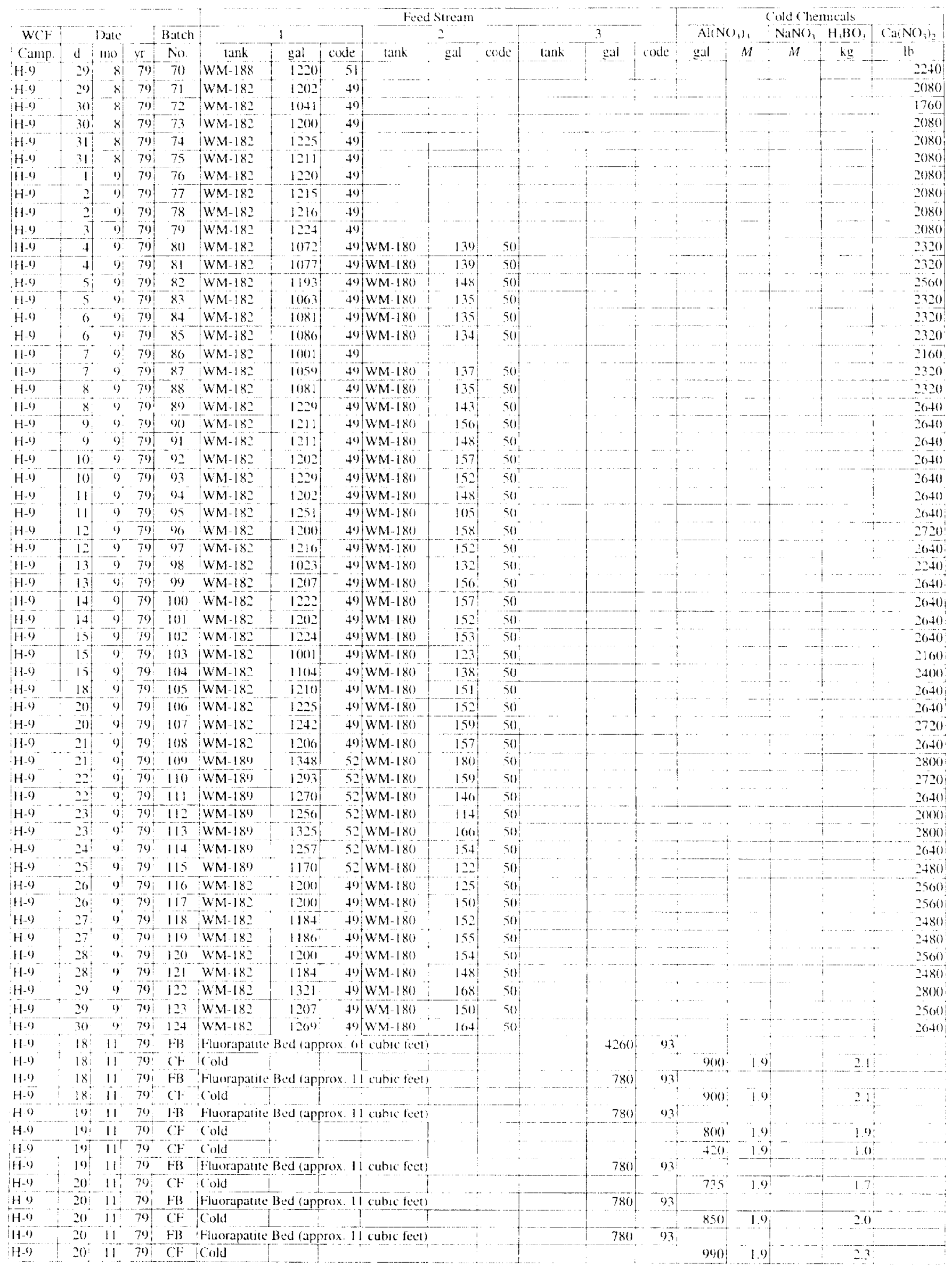


Table A3. Calciner Feed to Calcined Solids Storage Facility III. (continued)

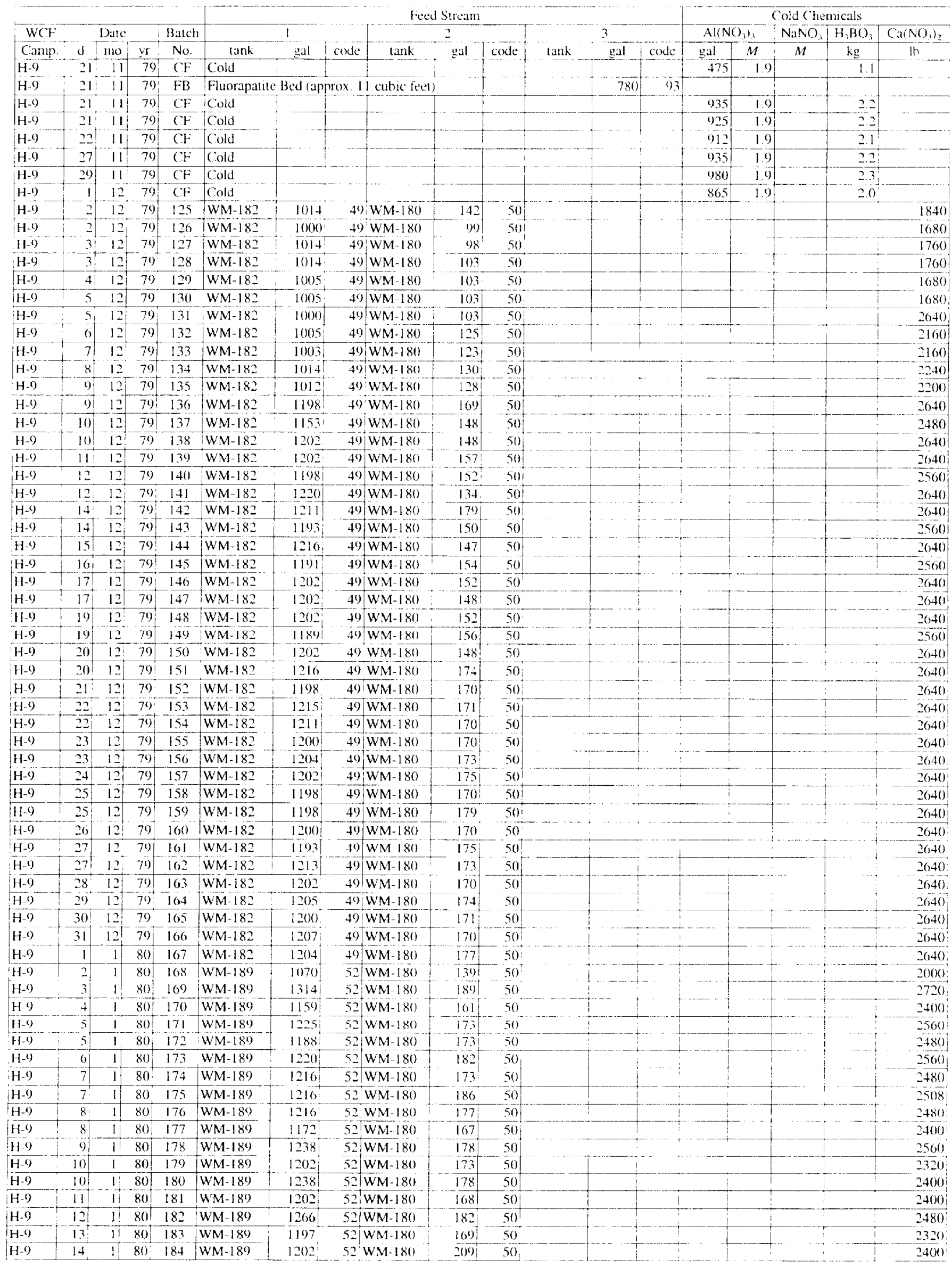


Table A3. Calciner Feed to Calcined Solids Storage Facility III. (continued)

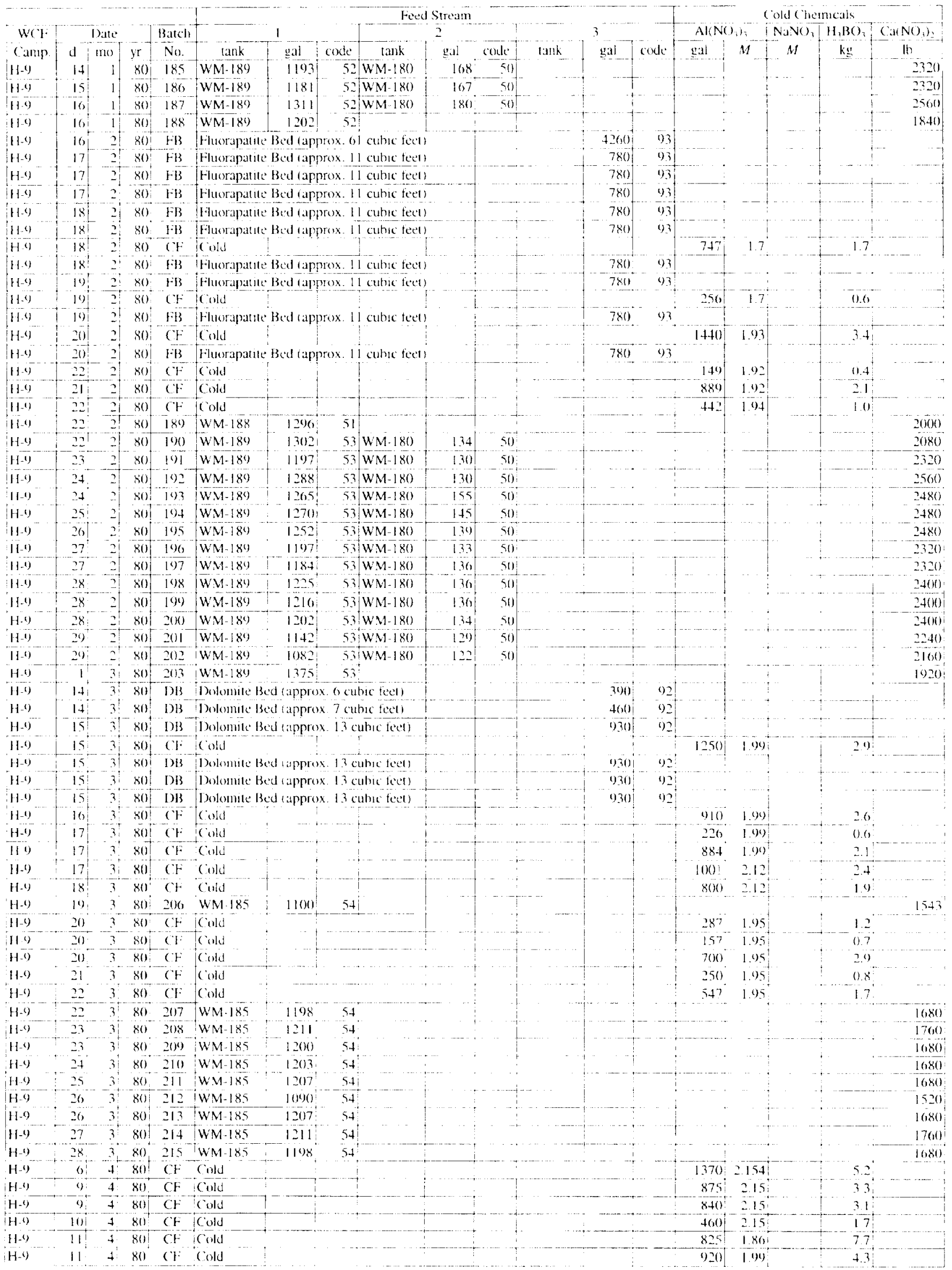


Table A3. Calciner Feed to Calcined Solids Storage Facility III. (continued)

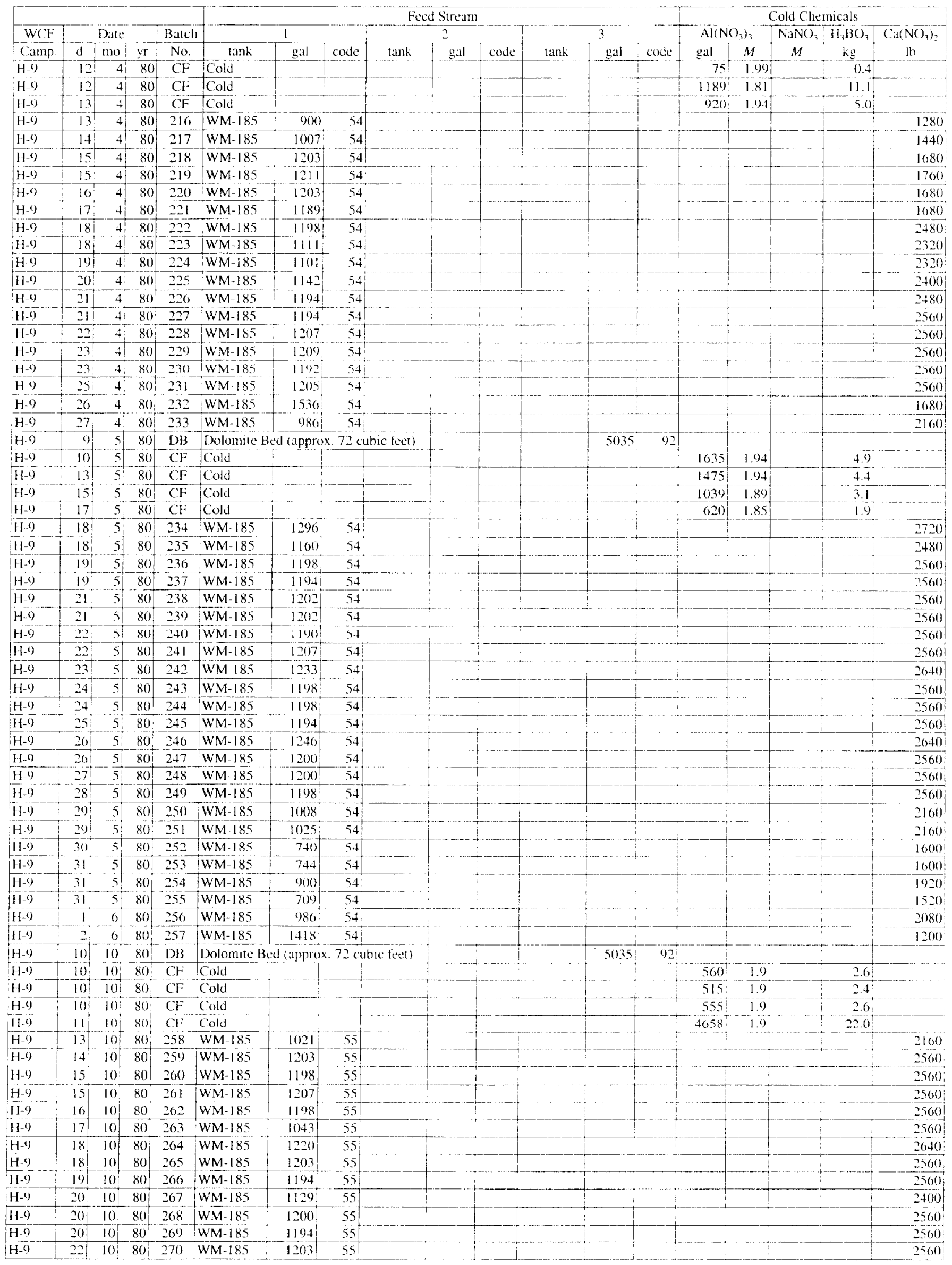


Table A3. Calciner Feed to Calcined Solids Storage Facility III. (continued)

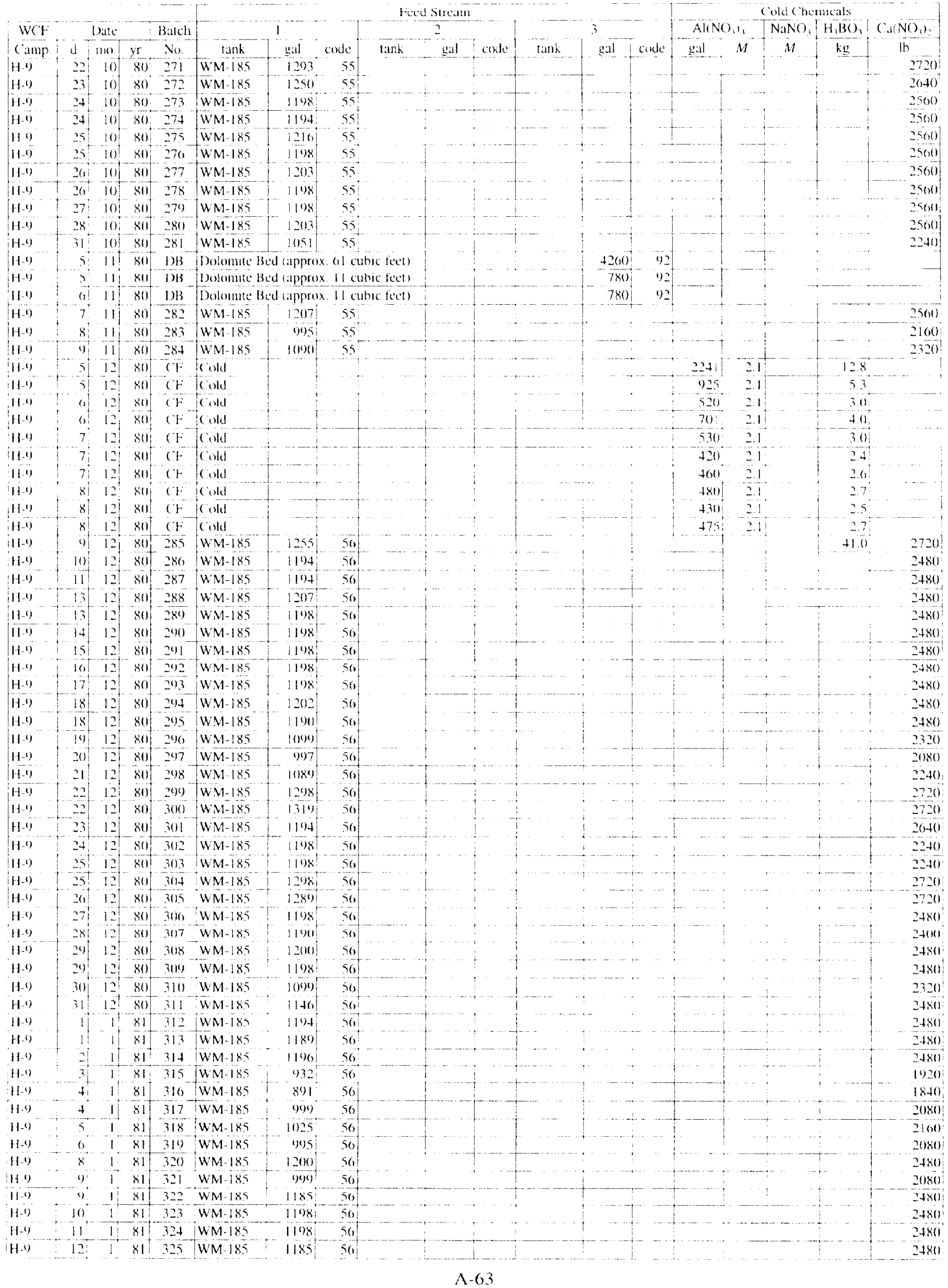


Table A3. Calciner Feed to Calcined Solids Storage Facility III. (continued)

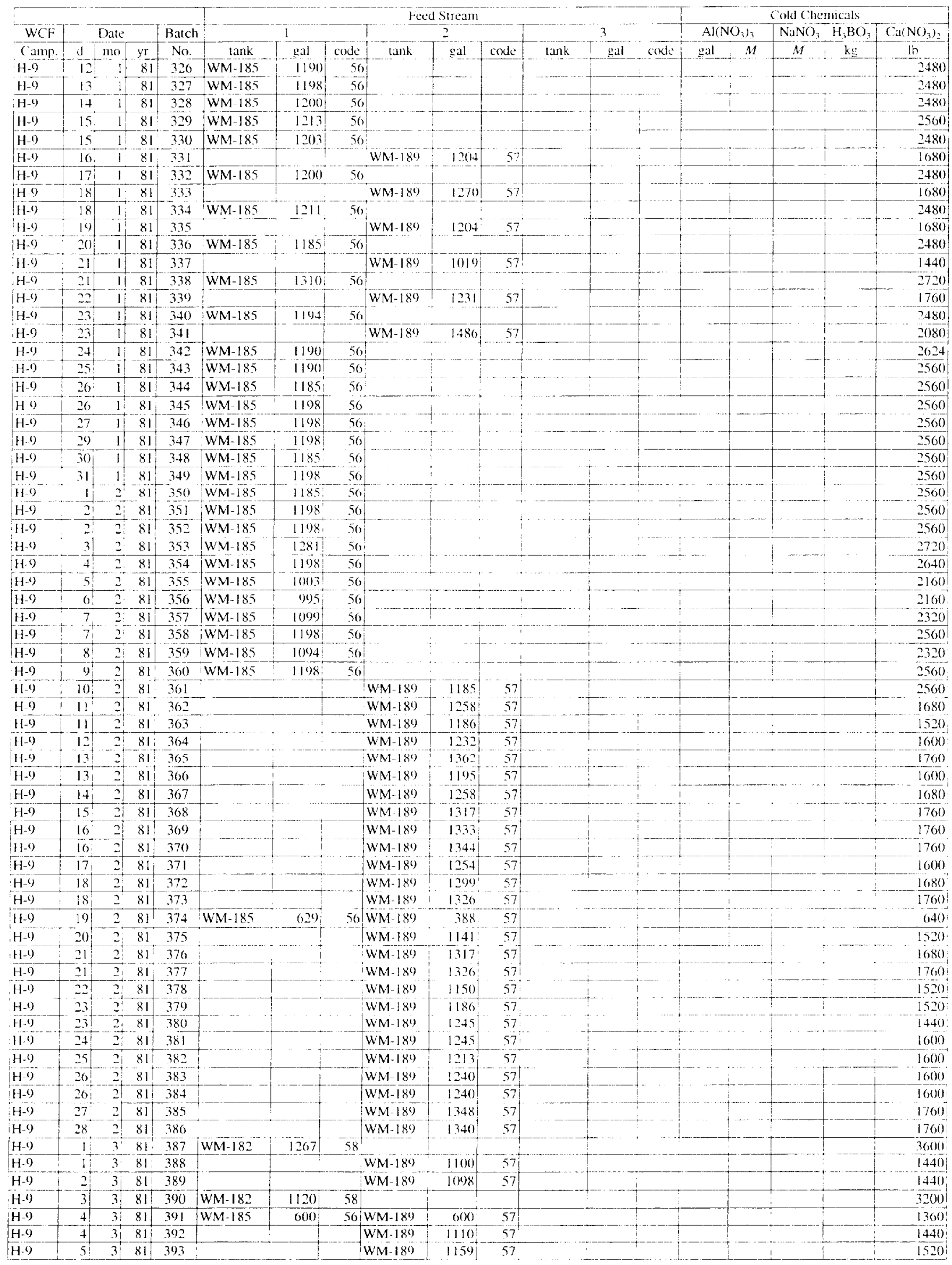


Table A3. Calciner Feed to Calcined Solids Storage Facility III. (continued)

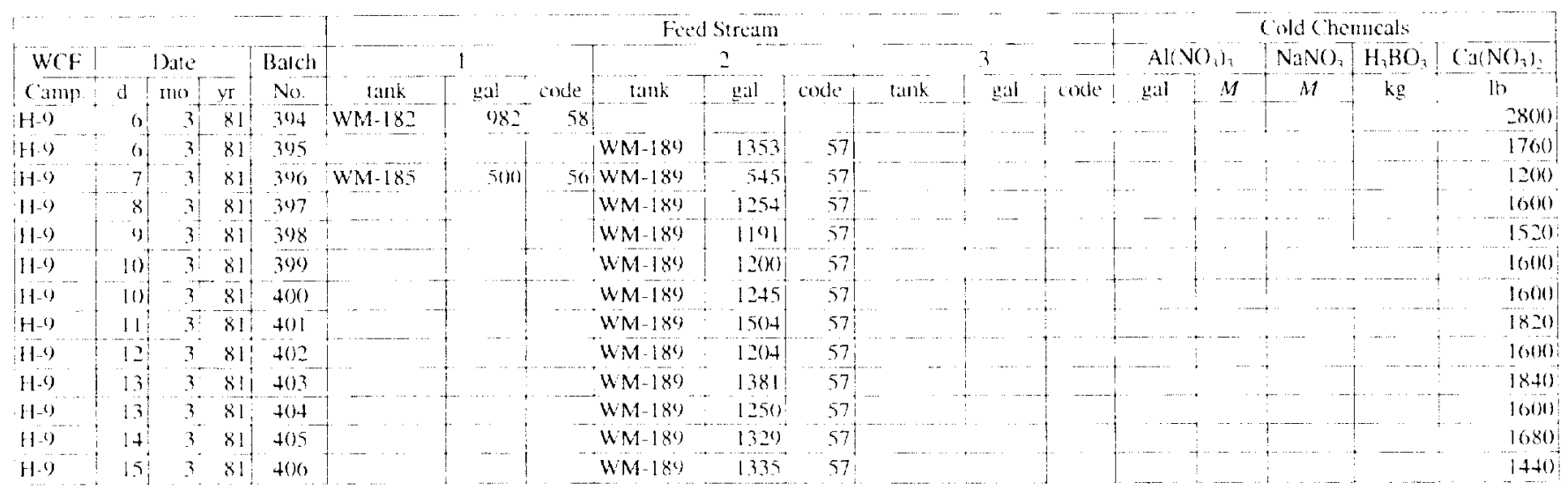


page intentionally blank 
Table A4. Calciner Feed to Calcined Solids Storage Facility IV.

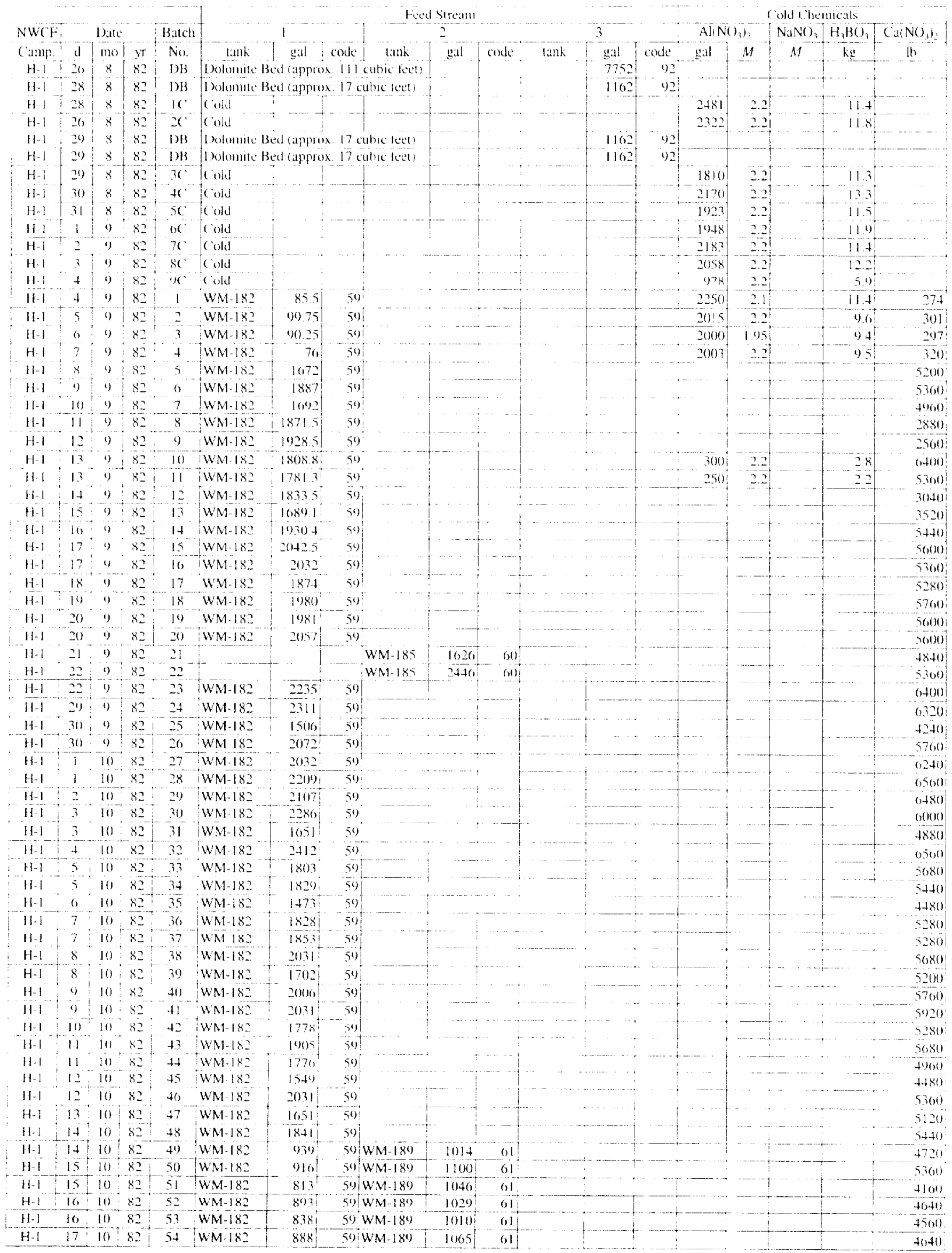


Table A4. Calciner Feed to Calcined Solids Storage Facility IV. (continued)

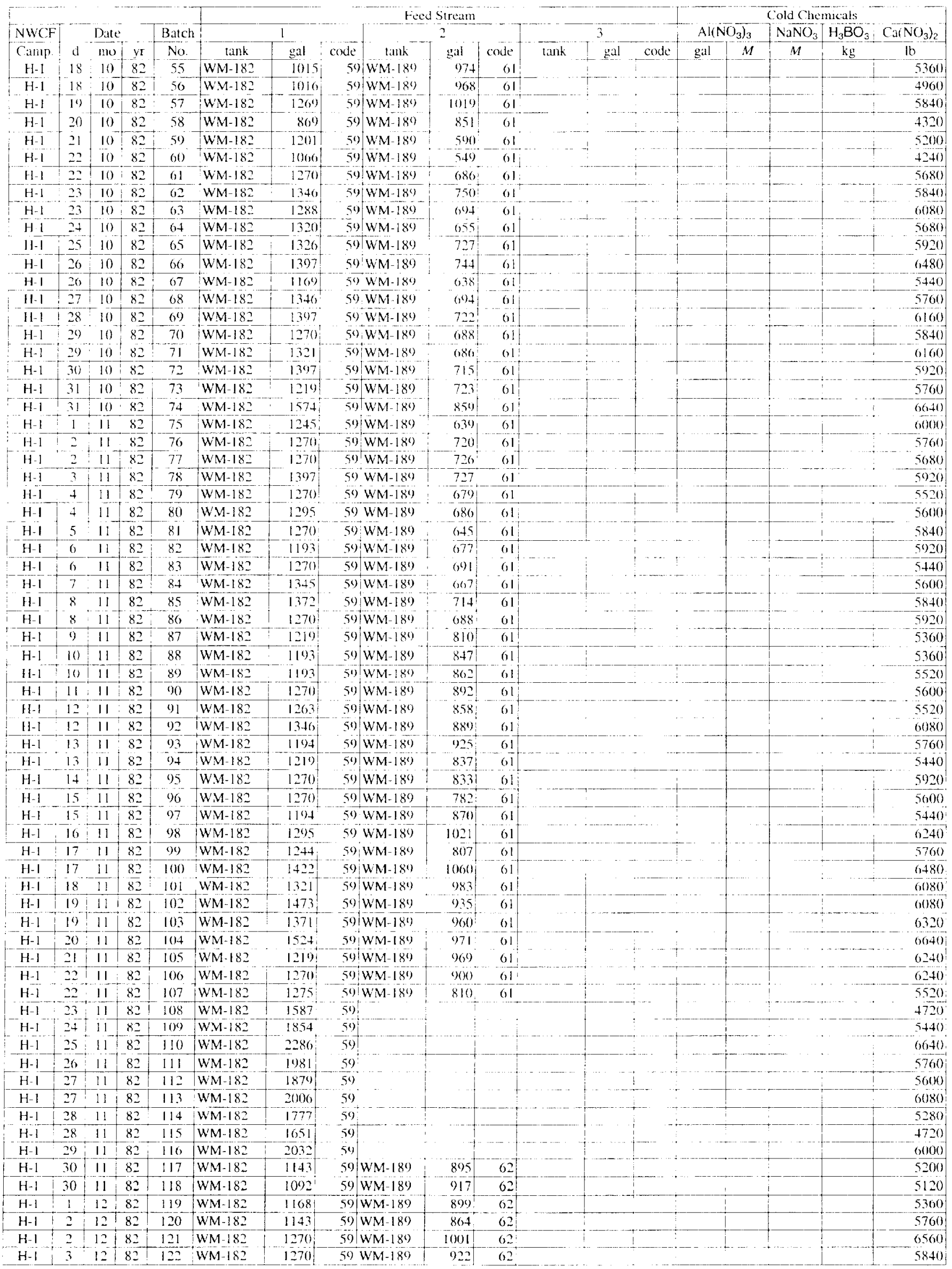


Table A4. Calciner Feed to Calcined Solids Storage Facility IV. (continued)

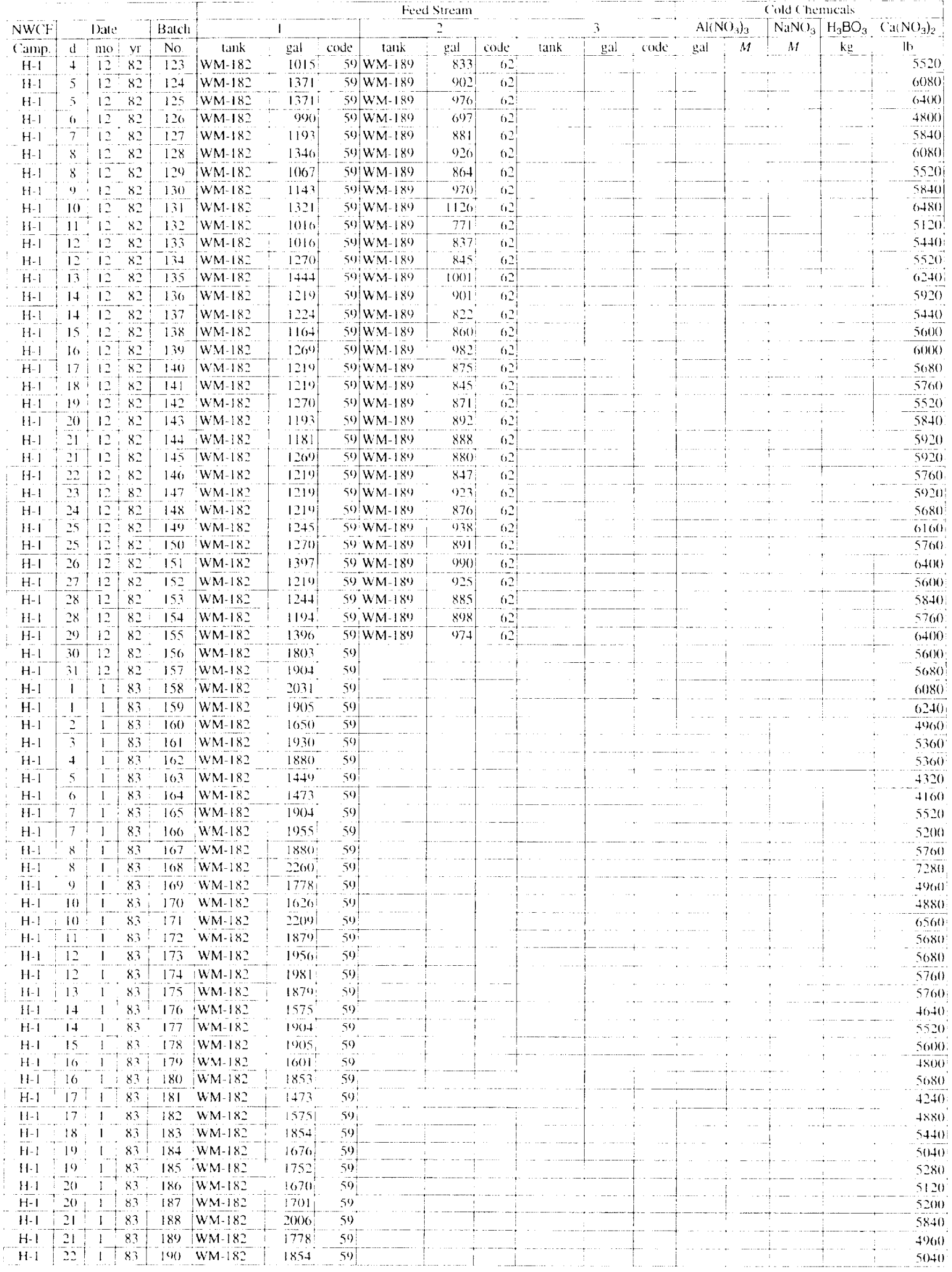


Table A4. Calciner Feed to Calcined Solids Storage Facility IV. (continued)

\begin{tabular}{|c|c|c|c|c|c|c|c|c|c|c|c|c|c|c|c|c|c|c|}
\hline \multirow{4}{*}{$\begin{array}{c}\text { NWCF } \\
\text { Camp } \\
\mathrm{H}-\mathrm{I}\end{array}$} & \multirow{2}{*}{\multicolumn{3}{|c|}{ Date }} & \multirow{4}{*}{$\begin{array}{c}\text { Batch } \\
\text { No. } \\
19 !\end{array}$} & \multicolumn{9}{|c|}{ Fed stream } & & & Cold Cher & micals & \\
\hline & & & & & & 1 & & & 2 & & & 3 & & AlliNi & $\left.3_{3}\right)_{3}$ & $\mathrm{NuNO}_{3}$ & $\mathrm{H}_{3} \mathrm{BO}_{3}$ & $\mathrm{Ca}\left(\mathrm{NO}_{3}\right)_{2}$ \\
\hline & d & tho & yr & & lank & gal & code & tank & gal & code & lank & gal & code & gal & $M$ & $M$ & $\mathrm{~kg}$ & $\mathrm{lb}$ \\
\hline & 23 & 1 & 83 & & WM-182 & 1460 & 59 & & & & & & & & & & & 4240 \\
\hline $\mathrm{H}-\mathrm{I}$ & 23 & 1 & 83 & 192 & WM-185 & 1708 & 60 & & & & & & & & & & & 4880 \\
\hline $\mathrm{H}-\mathrm{I}$ & 24 & 1 & 83 & 193 & WM-185 & 1980 & 60 & & & & & & & & & & & $4+480$ \\
\hline $\mathrm{H}-\mathrm{I}$ & 24 & 1 & 83 & 194 & WM-185 & 1830 & 60) & & & & & & & & & & & +500 \\
\hline $\mathrm{H}-\mathrm{I}$ & 25 & 1 & 83 & 195 & WM-185 & 2012 & 60 & & & & & & & & & & & 4560 \\
\hline $\mathrm{H}-1$ & 25 & 1 & 83 & 196 & WM-185 & 1275 & 60 & WM-189 & 690 & 62 & & & & & & & & 4400 \\
\hline $\mathrm{H}-1$ & 26 & 1 & 83 & 197 & WM-185 & 1.320 & 60 & WM- 89 & 708 & 62 & & & & & & & & +720 \\
\hline $\mathrm{H}-1$ & 27 & 1 & 83 & 198 & WM- 185 & 1199 & 60 & WM-189 & 659 & 02 & & & & & & & & 4240 \\
\hline $\bar{H}-1$ & 27 & 1 & 83 & $1 \%$ & WM-185 & 1198 & 60 & WM-189 & 627 & 62 & & & & & & & & 4160 \\
\hline $\mathrm{H}-1$ & 28 & 1 & 83 & 200 & WM-185 & 1275 & 60 & WM-189 & $700 !$ & 62 & & & & & & & & 4480 \\
\hline $\mathrm{H}-1$ & 29 & 1 & 83 & 201 & $W M-185$ & 1428 & 60 & WM-189 & 793 & 62 & & & & & & & & 5120 \\
\hline $\mathrm{H}-1$ & 29 & 1 & 83 & 2012 & WM-185 & 1046 & 60 & WM-189) & 771 & 02 & & & & & & & & 5040 \\
\hline $\mathrm{H}-1$ & 30 & 1 & 83 & 203 & WM-185 & 1224 & 60 & WM-189 & 723 & 62 & & & & & & & & $4+400$ \\
\hline $\mathrm{H}-\mathrm{I}$ & 31 & 1 & 83 & 204 & WM- 185 & 1244 & $60)$ & WM-189 & 698 & 02 & & & & & & & & $4640 !$ \\
\hline $\mathrm{HI}$ & 31 & $i$ & 83 & 205 & Retumed 1 & ank Farm & & & & & & & & & & & & \\
\hline $\mathrm{H}-\mathrm{I}$ & 13 & 3 & 83 & $D B$ & Dolomite 1 & d (approx & x. (9) $\mathrm{cu}$ & uhic lect) & & & & 6977 & $9=1$ & & & & & \\
\hline $\mathrm{H}-\mathrm{I}$ & 14 & 3 & 83 & $205 \mathrm{C}$ & cold & & & & & & & & & 2273 & 2.2 & & 130 & \\
\hline $\mathrm{H}-\mathrm{I}$ & 14 & 3 & 83 & $\mathrm{DB}$ & Dolomie & $I$ Iapprox. & $17 \mathrm{cu}$ & ubic feets & & & & 1162 & 92 & & & & & \\
\hline $\mathrm{H}-\mathrm{I}$ & 14 & 3 & 83 & $\mathrm{DB}$ & Dolomite & 1 approx & $17 \mathrm{cu}$ & ubic feet & & & & 1162 & 92 & & & & & \\
\hline$H-1$ & 19 & 3 & 83 & $D B$ & Dotomite & 1 iapprox & $\times 17 \mathrm{~cm}$ & uhic fert) & & & & 1602 & $0 ?$ & & & & & \\
\hline $\mathrm{H}-1$ & 10 & 3 & 83 & $206 \mathrm{C}$ & Cold & & & & & & & & & 2885 & 2.2 & & $13.5^{\circ}$ & \\
\hline $\mathrm{H}-\mathrm{l}$ & 21 & 3 & 83 & 2070 & Cold & & & & & & & & & 2208 & 22 & & 14.2 & \\
\hline $\mathrm{H}-1$ & 22 & 3 & 83 & 2080 & Cold & & & & & & & & & 2056 & 2.2 & & 12.9 & \\
\hline $\mathrm{H}-\mathrm{l}$ & 2.3 & 3 & 83 & 21096 & Cold & & & & & & & & & 2004 & 2.2 & & 12.5 & \\
\hline $\mathrm{H}-1$ & 23 & 3 & $83 !$ & 210 & WM- 185 & 1658 & 60 & & & & & & & & & & & $432 n$ \\
\hline $11-1$ & 24 & 3 & 83 & 211 & $W M-185$ & 1835 & $60)$ & & & & & & & & & & & 4640 \\
\hline $\mathrm{H}-1$ & 25 & 3 & 83 & 212 & WM-185 & 1657 & 60 & & & & & & & & & & & $4+400$ \\
\hline $\mathrm{H}-1$ & 20 & 3 & 83 & 213 & WM-185 & 1964 & (6) & & & & & & & & & & & 4400 \\
\hline $\mathrm{H}-1$ & 26 & 3 & 83 & 214 & WM- 185 & 1785 & 60 & & & & & & & & & & & 4160 \\
\hline $\mathrm{H}-\mathrm{I}$ & 27 & 3 & 83 & 215 & WM-185 & 1862 & $60 !$ & & & & & & & & & & & 4560 \\
\hline $\mathrm{H}-\mathrm{I}$ & 27 & 3 & 83 & 216 & WM-185 & 1830 & 60) & & & & & & & - & & & & 4640 \\
\hline $\mathrm{H}-\mathrm{I}$ & 28 & 3 & 83 & 217 & WM- 18.5 & 1836 & 60 & & & & & & & & & & & 4560 \\
\hline $\mathrm{H}-\mathrm{I}$ & 29 & 3 & 83 & 218 & WM-185 & 1887 & 60 & & & & & & & & & & & 4800 \\
\hline $\mathrm{H}-\mathrm{I}$ & 29 & 3 & 83 & 219 & WM-185 & 2168 & 60 & & & & & & & & & & & 4800 \\
\hline $\mathrm{H}-1$ & 30 & 3 & 83 & 220 & WM-185 & 1504 & 60 & & & & & & & & & & & 4080 \\
\hline $\mathrm{H}-1$ & 31 & 3 & 83 & 221 & WM-185 & 1811 & 60 & & & & & & & & & & & $46+0$ \\
\hline $1-1$ & 31 & 3 & 83 & 222 & WM-185 & 1402 & 60 & $W M-189$ & 600 & 03 & & & & & & & & 4) 60 \\
\hline $\mathrm{H}-1$ & 1 & 4 & 83 & 223 & WM-185 & 1122 & $60)$ & WM-189 & 492 & 63 & & & & & & & & 4400 \\
\hline $\mathrm{H}-1$ & 2 & 4 & 83 & 224 & WM-185 & 1007 & 601 & $W M-189$ & 564 & 63 & & & & & & & & 5120 \\
\hline $\mathrm{HI}$ & 2 & 4 & 83 & 225 & WM-185 & 1453 & 60 & $W M-180$ & $565^{-}$ & 63 & & & & & & & & 5280 \\
\hline $\mathrm{H}-1$ & 3 & 4 & 83 & 226 & WM-185 & 1785 & $60 \mid$ & WM-189 & 673 & 6.3 & & & & & & & & 5760 \\
\hline $\mathrm{H}-1$ & 3 & 4 & 83 & 227 & WM-185 & 1785 & $600]$ & WM-189 & 608 & 63 & & & & & & & & 5760 \\
\hline $\mathrm{H}-1$ & 4 & 4 & 83 & 228 & WM-185 & 1581 & 6015 & WM-189 & 641 & 6.3 & & & & & & & & 5520 \\
\hline $\mathrm{H}-\mathrm{I}$ & 5 & 4 & 83 & 229 & WM-185 & 17851 & (6) & $W M-189$ & 682 & 63 & & & & & & & & 5440 \\
\hline $\mathrm{H}-1$ & 5 & 4 & 83 & 230 & WM-185 & 1000 & $601 \mathrm{Y}$ & $W M-180$ & 582 & 63 & & & & & & & & 5440 \\
\hline $\mathrm{H}-\mathrm{I}$ & 6 & 4 & 83 & 231 & WM-185 & $1530 !$ & 60) $\mathrm{V}$ & WM-180 & $601^{\circ}$ & 63 & & & & & & & & 5600 \\
\hline $\mathrm{H}-1$ & 7 & 4 & 83 & 232 & WM- 185 & 1530 & 6) & WM-1 89 & 580 & 0.3 & & & & & & & & 5440 \\
\hline $\mathrm{H}-\mathrm{I}$ & 7 & 4 & 83 & 233 & WM- 185 & 1529 & $60\}$ & WM-189 & $6013^{7}$ & 6.3 & & & & & & & & 5440 \\
\hline $\mathrm{H}-\mathrm{I}$ & 8 & 4 & 83 & 234 & WM-185 & 1913 & $60 \sqrt{1}$ & $W M-188^{\circ}$ & $860^{\circ}$ & 63 & & & & & & & & 6080 \\
\hline $\mathrm{H}-1$ & $\%$ & 4 & 837 & 23.5 & WM-185 & 1657 & 600 & WM-189 & 619 & 6.3 & & & & & & & & 5680 \\
\hline $\mathrm{H}-\mathrm{I}$ & () & 4 & 83 & 230 & $W M-185$ & 1530 & 6014 & WM-189 & $592:$ & 63 & & & & & & & & $5520 !$ \\
\hline $\mathrm{H}-\mathrm{I}$ & 10 & 4 & 83 & 237 & $\bar{W}-185$ & 1058 & 6014 & WM-189 & 600 & 63 & & & & & & & 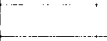 & 5520 \\
\hline $\mathrm{H}-\mathrm{l}$ & 11 & 4 & 83 & 238 & $W M-185$ & 1733 & 6) ! & WM-189 & 605 & 6.3 & & & & & & & & $56(0)$ \\
\hline $\mathrm{H} \cdot \mathrm{I}$ & 11 & 4 & 831 & 231 & $W M-185$ & 1750 & (6) & WM-181) & 592 & 6.3 & & & & & & & & 5680 \\
\hline $\mathrm{H}-1$ & 12 & 4 & 83 & $240^{-}$ & WM-185 & 1032 & $6 0 \longdiv { 1 }$ & WM-18) & $6(6)$ & 0.3 & & & & & & & & 5000 \\
\hline $\mathrm{H}-1$ & 13 & 4 & 83 & 241 & WM-185 & [81] & 601 & WM-189 & $716 !$ & 63. & & & & & & & & 5360 \\
\hline $\mathrm{H}-\mathrm{l}$ & 13 & 4 & 83 & 242 & WM- 185 & 1760 & $60 \mathrm{y}$ & WM-189 & 586 & 63 & & & & & & & & 5120 \\
\hline $13-1$ & 14 & + & 83 & 243 & WM-185 & 1530 & $60 \mathrm{~V}$ & WM-189 & 5811 & 6.3 & & & & & & & & 5120 \\
\hline $\mathrm{H}-1$ & 14 & 4 & 83 & 244 & WM- 185 & 1785 & $60 \mathrm{~V}$ & WM-189 & 601 & 03 & & & & & & & & 5200 \\
\hline $\mathrm{H}-1$ & 15 & 4 & 83 & 245 & $W M-185$ & 1249 & $60)$ & WM-189) & 486 & 63 & & & & & & & & 4160 \\
\hline$H-1$ & 16 & 4 & 83 & 246 & WM-185 & 1402 & $60 \sqrt{5}$ & WM-189 & 510 & 63 & & & & & & & & 4160 \\
\hline $\mathrm{H}-1$ & 10 & 4 & 83 & 247 & $W M-185$ & 1657 & (6) & $W M-189$ & 6511 & 6.3 & & & & & & & & 51340 \\
\hline $\mathrm{H}-1$ & 17 & 4 & 83 & 248 & $W M-185$ & 1530 & 60.2 & $W \bar{M}-189$ & 595 & 63 & & & & & & & & 5120 \\
\hline $\mathrm{H}-\mathrm{I}$ & 18 & 4 & 83 & 249 & W-185 & 1658 & $60 \mathrm{~V}$ & $\bar{W} \bar{M}-189$ & 670 & 63 & & & & & & & & $50 \overline{10}$ \\
\hline $\mathrm{H}-1$ & 18 & 4 & 83 & 250 & WM-185 & 1683 & $6 0 \longdiv { \mathrm { V } }$ & WM-189 & $607 !$ & 6.3 & & & & & & & & 5360 \\
\hline $\mathrm{H}-\mathrm{I}$ & 19 & 4 & 83 & 251 & WM-185 & $1550^{\top}$ & 604 & $W M-189$ & $670^{\circ}$ & 63 & & & & & & & & 5200 \\
\hline $\mathrm{H}-1$ & 19 & 4 & 8.3 & 252 & WM-185 & 1785 & $00 \mathrm{iv}$ & WM-189 & $584 !$ & 0.3 & & & & & & & & 5120 \\
\hline $\mathrm{H}-1$ & 20 & 4 & 83 & $253^{\circ}$ & WM- 185 & $1887 !$ & $60 \mathrm{~V}$ & $W M-180$ & $6 \times 4$ & $63^{3}$ & & & & & & & & 5200 \\
\hline
\end{tabular}


Table A4. Calciner Feed to Calcined Solids Storage Facility IV. (continued)

\begin{tabular}{|c|c|c|c|c|c|c|c|c|c|c|c|c|c|c|c|c|c|}
\hline & & & & & & & & & treami & & & & & & 16 & cals & \\
\hline NWCF & & Wate & & Batch & & 1 & & & 2 & & & 1 & Alcono & & $\mathrm{NaNO}_{3}$ & $\mathrm{H}_{3} \mathrm{BO}_{3}$ & $\operatorname{cor}\left(\mathrm{NO}_{3}\right)_{2}$ \\
\hline Canp & d & 180 & $\mathrm{yr}$ & $\mathrm{No}$ & $\operatorname{tank}$ & gal & code & tank & $\mathrm{g}, \mathrm{sl}$ & colde & lank & yal & gal & $M$ & $M$ & $k g$ & th \\
\hline $\mathrm{H}-1$ & 21 & 4 & 83 & 254 & WM-185 & 1709 & 60 & WM-189 & $583 !$ & 63 & & & & & & & +960 \\
\hline $\mathrm{H}-1$ & 21 & 4 & 83 & 255 & WM- 185 & 1604 & 60 & WM-189 & 702 & 6.3 & & & & & & & 5120 \\
\hline $\mathrm{H} \cdot \mathrm{l}$ & 22 & 4 & 83 & 250 & WM 185 & 178.5 & 60] & WM-189 & 0.32 & 6.3 & & & & & & & $5280:$ \\
\hline$H-1$ & 22 & 4 & 8.3 & 257 & WM-I & 15801 & 60 & $W M-189$ & 647 & 63 & & & & & & & 5120 \\
\hline $\mathrm{H}-\mathrm{I}$ & 23 & 4 & 83 & 258 & WM-185 & 1633 & (6) & WM-189 & 657 & 63 & & & & & & & 4060 \\
\hline$H-1$ & 2.4 & 4 & 83 & 259 & WM-185 & $1530^{\circ}$ & (6) & WM-189 & $6 \times 8$ & 63. & & & & & & & 4960 \\
\hline $11-1$ & 25 & 4 & 83 & 260 & WM 18 & 683 & 60 & WM- 189 & 577. & (1) 3 & & & & & & & $5(1+0)$ \\
\hline $11-1$ & 25 & 4 & 83 & 201 & $M-18$ & 1785. & 6) & $W M-189$ & $(60) !$ & 63 & & & & & & & 4960 \\
\hline$H-1$ & 26 & 4 & 8 & 262 & $M-185$ & $1555^{\circ}$ & 60 & WM 189 & 6,59 & 6,3 & & & & & & & 5360 \\
\hline $\mathrm{H}-\mathrm{I}$ & 20 & 4 & 83 & 263 & $M-185$ & 1734 & (c) & W & 613 & 6.7 & & & & & & & $5040 !$ \\
\hline $\mathrm{H}-\mathrm{I}$ & 27 & 4 & 8.3 & 264 & $\mathrm{M}-185$ & $17855^{\circ}$ & 60) & $\mathrm{W}$ & $6.50) !$ & 6.3 & & & & & & & $5200 !$ \\
\hline $\mathrm{H}-\mathrm{H}$ & 28 & + & 83 & 265 & $M-185$ & $1780 !$ & 6) & $w$ & 7109 & 6.3 & & & & & & & 5760 \\
\hline $\mathrm{HI}$ & 28 & 4 & 83 & 260 & M.185 & 1830 & 6) & 21) & 0.30 & 6.31 & & & & & & & $5040 !$ \\
\hline $11-1$ & 29 & 4 & 8.3 & 267 & $W M-185$ & 1734 & 60) & (1) & $(1+4)^{?}$ & 6.3 & & & & & & & 4800 \\
\hline $\mathrm{H}-\mathrm{I}$ & 29 & 4 & 83 & 268 & $M-18$ & 1760 & 60) & i & 712 & 6.3[ & & & & & & & 5280 \\
\hline $\mathrm{H}-\mathrm{I}$ & 30) & 4 & 8. & 269 & $W M-1$ & 1836 & (6) & WM-189 & 63.3 & 10.3 & & & & & & & 4880 \\
\hline $\mathrm{H}-\mathrm{I}$ & 1 & 5 & 8.3 & 270 & WM- 18.5 & $1551_{j}$ & 60 & WM-189 & 644 & 6.3 & & & & & & & 4720 \\
\hline $\mathrm{H}-1$ & 1 & 5 & 83 & 27 & $W M-185$ & 1581 & 60) & Q?) & 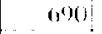 & 6., 5 & & & & & & & 4560 \\
\hline$H 1-1$ & 2 & 5 & 83 & 272 & WM-185 & 1581 & 60 & 89 & 654 & 613 & & & & & & & $4(240$ \\
\hline $\mathrm{H}-\mathrm{I}$ & $?$ & 5 & 83 & 273 & WM-185 & $1606 !$ & 60) & 89 & 0,05 & 6.3 & & & & & & & 4640 \\
\hline $\mathrm{H}-1$ & 3 & 5 & 83 & 274 & WM-185 & 16017 & 6) & & 60,0 & $(1,3)$ & & & & & & & 4560 \\
\hline$H-1$ & 4 & 5 & 8 & 275 & WM- & 1887 & (6) & & $7(x)]$ & $(1,3$ & & & & & & & 5280 \\
\hline $\mathrm{H}-1$ & 4 & 5 & 83 & 276 & WM-185 & 1862. & (6) & 30 & 072 & 6,3 & & & & & & & 53600 \\
\hline $\mathrm{H}-\mathrm{I}$ & 5 & 5 & 83 & 277 & WM-I & 1989 & 00 & $w$ & 0,77 & 0,3 & & & & & & & 5520 \\
\hline $\mathrm{H}-\mathrm{I}$ & 6 & $\therefore$ & 83 & 278 & $W M-1$ & 1071 & (6) & iv & 422 & $6,3:$ & & & & & & & 30411 \\
\hline H & 0 & 5 & 83 & 279 & WN & 1033 & 00 & $w$ & ox & 6,3 & & & & & & & $46+401$ \\
\hline $\mathrm{H}-\mathrm{I}$ & 7 & 5 & 83 & 280 & $W N$ & 1700 & 60 & $\mathrm{~W}$ & 644 & 6,3 & & & & & & & 4880 \\
\hline $11-1$ & 7 & 5 & 8.3 & 281 & Wn & $1658^{\circ}$ & 60 & $w$ & $6(60)$ & 639 & & & & & & & +560 \\
\hline 11.1 & 8 & 5 & 83 & 282 & u & 10 & 60 & $w$ & 591 & 633 & & & & & & & 48010 \\
\hline $\mathrm{HI}$ & ") & 5 & 83 & 3 & $u$ & 16 & (6) & $u$ & $0,6.5$ & 63 & & & & & & & 4560 \\
\hline $\mathrm{H}-1$ & 9) & 5 & 8.3 & 284 & $w$ & 15 & (a) & $\mathrm{w}$ & 574 & 0.3 & & & & & & & 4500 \\
\hline $\mathrm{H}-1$ & 10) & 5 & 83 & 285 & 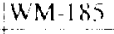 & 17 & (c) & & 692 & 6.3 & & & & & & & 57001 \\
\hline $1 i-1$ & 10 & 5 & 83 & 280 & IN & 15 & 60 & & (1) & 63 & & & & & & & 5120 \\
\hline-1 & 11 & 5 & 83 & 87 & W & is & 6) & & $6-$ & 63 & & & & & & & 5520 \\
\hline $\mathrm{H}$. & 12 & 5 & 83 & 88 & w & $1632 i$ & 60 & & $(0) 5$ & 63 & & & 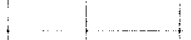 & & & & $5+40$ \\
\hline $\mathrm{H}$ & 12 & 5 & 83 & 89 & u & 17 & 6) & & 717 & 63 & & & & & & & 5680 \\
\hline $\mathrm{H}$ & 13 & 5 & 83 & 90 & $w$ & 16 & 60 & & 5 & 6. & & & & & & & 5300 \\
\hline $\mathrm{H}-1$ & 13 & 5 & 8.3 & 91 & $W M-$ & 18 & 6) & $w$ & 02 & (1) & & & & & & & 56000 \\
\hline $\mathrm{H}-1$ & 14 & 5 & 83 & 12 & $W M-1$ & 15 & 60) & w & 66 & $0 . ?$ & & & & & & & 5360 \\
\hline $11-1$ & 1.5 & 5 & 83 & 3 & WM-18 & $1683^{3}$ & $6 r$ & 89) & 001 & 6.3 & & & & & & & 5360 \\
\hline $\mathrm{H}-\mathrm{I}$ & 15 & 5 & 83 & 14 & $W M-18$ & & (6) & & 025 & 0.3 & & & & & & & 5440 \\
\hline $\mathrm{H}-\mathrm{I}$ & 16 & 5 & 8 & 95 & WM- & $1591^{\circ}$ & 60 & $w$ & 798 & 63 & & & & & & & $5440 !$ \\
\hline $\mathrm{H}-1$ & 16 & 5 & 8.3 & 296 & WM & $1620 !$ & 60) & $w$ & (1)!! & 6.3 & & & & & & & 5280 \\
\hline$H-1$ & 17 & 5 & 83 & 297 & WM-18 & 1658 & (6) & $w$ & 71) & 0.3 & & & & & & & 5280 \\
\hline $\mathrm{H}$ & 18 & 5 & 8.7 & 298 & $w$ & 165 & 0 & $w$ & 584 & (1) & & & & & & & 580 \\
\hline $\mathrm{H}-1$ & 18 & 5 & 8 & 290 & WM- 185 & $1530 !$ & 6) & $\mathrm{W}$ & (1)7 7 & $6 ?$ & & & & & & & 5280 \\
\hline $\mathrm{H}-\mathrm{I}$ & 19 & 5 & 83 & 10 & WM-185 & 1785 & (6) & $w$ & 6 & 0.3 & & & & & & & 5520 \\
\hline $\mathrm{H}-$ & 19 & 5 & 8 & 301 & WM-18 & 1836 & (6) & $w$ & 628 & 63 & & & & & & & 57601 \\
\hline $\mathrm{H}$ & 20 & 5 & 83 & 302 & $w$ & 1785 & (c) & i84) & 629 & 0.3 & & & & & & & 5300 \\
\hline $\mathrm{H}-1$ & 21 & 5 & 83 & 303 & WM-185 & 1632 & (6) & WM-189 & $6(1) 4$ & 03 & & & & & & & 5280 \\
\hline $\mathrm{H}-\mathrm{I}$ & 21 & 5 & 83 & 304 & $1-1$ & 1657 & 6) & $1-184$ & (1) & 63 & & & & & & & 5440 \\
\hline$H-$ & 22 & 5 & 83 & 305 & $1-185$ & 1607 & 60 & $1-189$ & 595 & $0 . i$ & & & & & & & 5200 \\
\hline $11-1$ & 22 & 5 & 83 & 306 & WM-185 & $\mid 6,32 !$ & 60 & WM-189 & 617 & 6.3 & & & & & & & 5360 \\
\hline $\mathrm{H}-\mathrm{I}$ & 23 & 5 & 8.3 & 307 & jW & 1785 & 60) & WM-189 & 585 ! & 0.3 & & & & & & & $54+4)$ \\
\hline $\mathrm{H}-1$ & 24 & 5 & 8.3 & 308 & WM-185 & $1802 !$ & 60 & WM-18 & 054 & 0.3 & & & & & & & $(2+2+1)$ \\
\hline H & 24 & 5 & 83 & $30 \%$ & & 178.5 & 60 & $(-184$ & 6001 & (1) 3 & & & & & & & 5280 \\
\hline $\mathrm{H}$ & 25 & 5 & 83 & & & $10 \times 2$ & 60 & W & $013 i$ & 63 & & & & & & & 5520 \\
\hline 11 & 26 & 5 & 83 & 31 & & $1581 !$ & (i) & & 7 & 0.3 & & & & & & & 5280 \\
\hline [1 & 26 & 5 & 8. & & & & 0 & & & 0 & & & & & & & 5440 \\
\hline$H$ & 27 & 5 & 8 & 3 & & & (1) & & & & & & & & & & 5280 \\
\hline $\mathrm{H}$ & 27 & 5 & 83 & 3 & & 883 & 60) & & 5 & (1) 3 & & & & & & & $5+40$ \\
\hline $\mathrm{H}$ & 28 & 5 & 8 & & & & 1) & & & 6 & & & & & & & 8760 \\
\hline II & 29 & 5 & 8 & 310 & $w$ & 15305 & (0) & $\mathrm{w}$ & ) & 63 & & & & & & & 5280 \\
\hline$H$ & $\therefore$ & 5 & 83 & 317 & w & & 00 & iw & 7 & 0.3 & & & & & & & 5280 \\
\hline $\mathrm{H}$ & 30 & 5 & 83 & 318 & w & 1006 & 60 & WM-184) & 6033 & $0.3^{3}$ & & & & & & & 5440 \\
\hline $\mathrm{H}-\mathrm{I}$ & $3 !$ & 5 & 83 & 319 & -185 & 1010 & 60 & $W M-189$ & 608 & 63 & & & & & & & 5280 \\
\hline $\mathrm{H}-1$ & 31 & 5 & 83 & 320 & $1-185$ & 1083 & 60 & $W M-18^{\circ}$ & 648 & 6,3 & & & & & & & 5440 \\
\hline H-1 & 1 & 6 & 83 & .321 & WM-185 & 1058 & 60 & $W M-189$ & 601 & 0.3 & & & & & & & 5200 \\
\hline
\end{tabular}


Table A4. Calciner Feed to Calcined Solids Storage Facility IV. (continued)

\begin{tabular}{|c|c|c|c|c|c|c|c|c|c|c|c|c|c|c|c|c|c|c|}
\hline \multicolumn{4}{|c|}{$\cdots-\cdots$} & & \multirow{2}{*}{\multicolumn{3}{|c|}{1}} & \multicolumn{6}{|c|}{ Feed Stream } & & $\ldots$ & Cold Chem & micals & \\
\hline NWCF & & Date & & Batch & & & & & 2 & & & 3 & & Alli & $\left.\mathrm{O}_{3}\right)_{3}$ & $\mathrm{NaNO}_{3}$ & $\mathrm{H}_{3} \mathrm{BO}_{3}$ & $\mathrm{Ca}\left(\mathrm{NO}_{3}\right)_{2}$ \\
\hline Camp. & d & ino & $\mathrm{yr}$ & No. & tank & gal & code & $\operatorname{tank}$ & $\mathrm{gal}$ & code & lank & $\overline{\mathrm{gal}}$ & code! & gal & $M$ & $M$ & $\mathrm{~kg}$ & $\mathrm{lb}$ \\
\hline $\mathrm{H}-1$ & 1 & 6 & 83 & .322 & WM-185 & 1631 & 60 & WM- 189 & 587 & 63. & & & & & & & & 5360 \\
\hline $\mathrm{H}-\mathrm{I}$ & 2 & 6 & 83 & 323 & $W M-185$ & 1530 & 60 & WM-189 & 590 & $63^{\dagger}$ & & & & & & & & 5120 \\
\hline $\mathrm{Hl}$ & 3 & 6 & 83 & 324 & WM 185 & 1658 & 60 & WM-189 & 597 & 0.3 & & & & & & & & 5360 \\
\hline$\underline{H}-1$ & 3 & 6 & 83 & 325 & WM-185 & $\mid 658$ & 60 & WM-189 & 595 & 63 & & & & & & & & 5360 \\
\hline $\mathrm{H}-\mathrm{I}$ & 4 & 6 & 83 & 326 & WM-185 & 1709 & 60 & $W M-189$ & $735^{\circ}$ & 635 & & & & & & & & 5600 \\
\hline $\mathrm{H}-1$ & 5 & 6 & 83 & 327 & WM-185 & 1735 & 60 & $W M-189$ & 683 & 63 & & & & & & & & 5360 \\
\hline $\mathrm{H}-\mathrm{l}$ & 5 & 6 & 83 & 328 & WM-185 & 1543 & 60 & WM-189 & 026 & 63 & & & & & & & & 5440 \\
\hline $\mathrm{HI}$ & 6 & 6 & 83 & 329 & WM 185 & 1479 & $60 !$ & WM 189 & 524 & 03 & & & & & & & & 4880 \\
\hline $\mathrm{H}-\mathrm{I}$ & 6 & 6 & 83 & 330 & WM- 185 & 1683 & 60 & WM-189 & 6.1. & 0.3 & & & & & & & & 5520 \\
\hline $\mathrm{H}-1$ & 7 & 6 & 83 & 331 & WM-185 & 1658 & 60) & WM- 189 & $6860^{\circ}$ & 63. & & & & & & & & $5 \overline{440}$ \\
\hline $\mathrm{H}-1$ & 8 & 6 & 83 & 332 & $W M-185$ & 1607 & 60 & WM-189 & 593 & 63 & & & & & & & & 5360 \\
\hline $\mathrm{H}-\mathrm{I}$ & 8 & 6 & 83 & $333^{-}$ & WM-185 & 1709 & 60 & $W M-189$ & 625 & 63 & & & & & & & & 5360 \\
\hline $\mathrm{H}-\mathrm{I}$ & 9 & 6 & 83 & 334 & WM-185 & $1555 \mathrm{i}^{\circ}$ & 60 & WM-180 & $\left.589\right|^{\circ}$ & 63 & & & & & & & & 5360 \\
\hline $\overrightarrow{\mathrm{H}} \mathrm{l}$ & 10 & 6 & 83 & 335 & WM-185 & 1683 & (6) & WM-189 & $597 !$ & 63 & & & & & & & & 52807 \\
\hline $\mathrm{H}-1$ & 10 & 6 & 83 & 336 & WM- 185 & 1657 & 601 & $W M-180$ & $647 !$ & 63. & & & & & & & & 5520 \\
\hline $\mathrm{H}-1$ & 11 & 6 & 83 & 337 & WM- 18.5 & 16321 & 601 & WM-189 & 611 & 63 & & & & & & & & 5280 \\
\hline $\mathrm{H}-1$ & 11 & 0 & 83 & 338 & WM-185 & $2116 !$ & 60 & & & & & & & & & & & 4960 \\
\hline $\mathrm{H}-1$ & 12 & 0 & 83 & 339 & WM-185 & 2295 & 601 & & & & & & & & & & & 5040 \\
\hline $\mathrm{H}-\mathrm{I}$ & 13 & 6 & 83 & 340 & WM-185 & 2116 & 60 & & & & & & & & & & & 4960 \\
\hline $\mathrm{H}-\mathrm{I}$ & 13 & 6 & $83\rceil$ & 341 & WM-185 & 2218 & 60 & & & & & & & & & & & $4900^{\circ}$ \\
\hline $\mathrm{H}-1$ & 14 & 6 & 83 & .342 & WM-185 & 1760 & 60 & WM-189 & 611 & $63 !$ & & & & & & & & 5440 \\
\hline $\mathrm{H}-1$ & 14 & 6 & 83 & 343 & WM-185 & 1632 & 601 & WM 189 & 582 & 631 & & & & & & & & 5440 \\
\hline $11-1$ & 15 & 6 & 83 & 344 & $W M-185$ & 1658 & o) & $W M-189$ & $592 !^{-}$ & 63 & & & & & & & & 5360 \\
\hline $\mathrm{H}-1$ & 10 & 6 & 83 & 345 & WM-185 & $160 \%$ & 60 & WM-189 & $540 !$ & 63 & & & & & & & & $4960 !$ \\
\hline $\mathrm{H}-1$ & 16 & 6 & 83 & 346 & $W M-185$ & 1657 & 60 & WM-189 & 6421 & 63 & & & & & & & & 5360 \\
\hline $\mathrm{H}-\mathrm{I}$ & 17 & 6 & 83 & 347 & WM-185 & 1581 & $60 \dagger$ & $W M-189$ & 680 & 63 & & & & & & & & 5360 \\
\hline $\mathrm{H}-1$ & 17 & 6 & 83 & 348 & WM-185 & 1734 & 60 & WM- 189 & 614 & 63. & & & & & & & & 5360 \\
\hline $\mathrm{H}-1$ & 18 & 6 & 83 & $34 \%$ & WM-185 & 1580 & 60 & WM-189 & 659 & 63 ! & & & & & & & & 5280 \\
\hline $\mathrm{H}-\mathrm{l}$ & 19 & 6 & 83 & 350 & WM- 185 & 1704 & 60 & $W \bar{M}-189$ & 609 & 63 & & & & & & & & 5440 \\
\hline $\mathrm{H}-1$ & 19 & 6 & 83 & 351 & $1-185$ & 1607 & (ii) & WM-189 & 680 & 63 & & & & & & & & 5360 \\
\hline $\mathrm{H}-\mathrm{I}$ & 20 & 6 & 83 & 352 & $M-185$ & 1734 & 60 & WM-189 & 720 & 63 & & & & & & & & 6000 \\
\hline H-1 & 21 & 6 & 83 & 353 & WM-185 & 1786 & 60 & WM-189 & $605 !$ & $63^{3}$ & & & & & & & & 5440 \\
\hline $\mathrm{H}-\mathrm{I}$ & 21 & 6 & 83 & 354 & $1-185$ & 1734 & 60 & WM-189 & 6301 & $63^{-}$ & & & & & & & & 5440 \\
\hline $\mathrm{H}-\mathrm{I}$ & 22 & $\overline{6}$ & 83 & 355 & $1-1$ & 1582 & 60 & WM- 189 & 612 & 63 & & & & & & & & 5280 \\
\hline $\mathrm{H}-1$ & 22 & 6 & 83 & 356 & WM- 185 & 1683 & 60 & 180 & 605 & 63 & & & & & & & & 5600 \\
\hline $1 \mathrm{H}-1$ & 23 & 6 & 83 & 357 & 5 & 1581 & 60 & WM-189 & 601 & 0.3 & & & & & & & & 5200 \\
\hline $\mathrm{H}-\mathrm{I}$ & 24 & 0 & 83 & 358 & 5 & 1708 & 60 & WM-189 & 573 & 0.3 & & & & & & & & 5200 \\
\hline $\mathrm{H}-\mathrm{I}$ & 24 & 0 & 8 & 359 & $M-185$ & 1810 & (6) 1 & WM-189 & $644 !$ & 6.3 & & & & & & & & $5360 !$ \\
\hline $\mathrm{H}-\mathrm{l}$ & 25 & 6 & 83 & 360 & WM- 185 & 1071 & 60 & WM-189 & 658 & $63 \mathrm{y}$ & $\mathrm{M}-188$ & 471 & & & & & & 5200 \\
\hline $\mathrm{H}-1$ & 25 & 6 & 83 & 361 & WM- 188 & 1778 & 66 & WM-189 & 632 & 03 & & & & & & & & 4960 \\
\hline $\mathrm{H}-1$ & 26 & 6 & 8 & 362 & 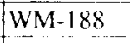 & $\left.1883\right|^{-}$ & ab) & WM-189 & 705 & 0.3 & & & & & & & & 5280 \\
\hline $\mathrm{H}-1$ & 27 & 0 & 82 & 363 & WM-188 & 1700 & 60 & WM-189 & 600 & 63 & & & & & & & & 4800 \\
\hline $\mathrm{H-1}$ & 27 & 6 & 83 & 364 & WM-188 & 1674 & 60 & WM-189 & 582 & 63 & & & & & & & & 4800 \\
\hline if-I & 28 & 6 & 83 & $36 \overline{5}$ & WM-188 & 1770 & 66 & WM-189 & 678 & 63 & & & & & & & & 4720 \\
\hline $\mathrm{HI}$ & 29 & 6 & 8 & 306 & WM 188 & 1674 & 667 & $W M-180$ & 584 & 63 & & & & & & & & 4800 \\
\hline $\mathrm{H}-1$ & 29 & 6 & 83 & 367 & WM-188 & 1720 & 66 & WM-189 & 595 & 63 & & & & & & & & 4800 \\
\hline $\mathrm{H}-\mathrm{I}$ & 30 & 6 & 83 & 368 & $1-188$ & 380 & 66 & & $i$ & & & & & & & & & 4480 \\
\hline $\mathrm{H}-\mathrm{I}$ & 1 & 7 & 83 & 369 & WM-188 & $1831^{\dagger}$ & 60 & WM-189 & 482 & 6.3 & & & & & & & & 5120 \\
\hline $\mathrm{H}-\mathrm{I}$ & 1 & 7 & 837 & 370 & $1-188$ & 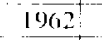 & $6 0 \longdiv { 1 }$ & WM-189 & 494 & 6.3 & & & & & & & & 4040 \\
\hline $\mathrm{H}-1$ & 2 & $7^{-1}$ & 837 & 371 & WM-188 & 1857 & 60 & $W M-18^{9}$ & 490 & 63 & & & & & & & & 4560 \\
\hline $\mathrm{H}-1$ & 3 & 7 & 83. & 372 & WM-188 & 1909 & 60 & WM-189 & 558 & 637 & & & & & & & & 4560 \\
\hline $\mathrm{H}-1$ & 3 & 7 & 8. & 37.3 & WM-188 & 1962 & 60 & $\mathrm{~W} M-189$ & 595 & 63 & & & & & & & & 4800 \\
\hline $\mathrm{H}-\mathrm{I}$ & 4 & 7 & 83 & 374 & WM-188 & 1936 & 601 & WM- 189 & 490 & 63 & & & & & & & & 4040 \\
\hline $\mathrm{H}-\mathrm{l}$ & 5 & 2 & 83 & 375 & $W M-188$ & 1857 & $66)$ & WM-189 & 552 & 63 & & & & & & & & 4400 \\
\hline III-1 & 5 & 7 & 83 & 376 & WM-188 & 1988 & 661 & WM-189 & $560 !$ & 63 & & & & & & & & $480 \%$ \\
\hline $\mathrm{H}-1$ & 0 & 7 & 83 & 377 & $W M-188$ & 2040 & 66 & WM-189 & 530 & $6.3 i^{+\cdots}$ & & & & & & & & 4880 \\
\hline $\mathrm{H}-\mathrm{I}$ & 6 & 7 & 8.3 & 378 & $4-188$ & 1854 & 60 & WM-189 & $483 i$ & 63 & & & & & & & & 2640 \\
\hline $\mathrm{H}-\mathrm{I}$ & 7 & 7 & 83 & 379 & $4-188$ & 1988 & $66 !$ & WM-189 & 547 & $63 !$ & & & & & & & & 4800 \\
\hline $\mathrm{H}-\mathrm{I}$ & 8 & 7 & 83 & 380 & $1-188$ & 1883 & 66 . & WM-189 & 5.39 & $633^{\circ}$ & & & & & & & & 4960 \\
\hline II -1 & 8 & 7 & 83 & 381 & -188 & 1582 & $\operatorname{roj}$ & WM-189 & 458 & $633^{4}$ & & & & & & & & 4160 \\
\hline $\mathrm{H}-1$ & 9 & 7 & 83 & 382 & $1-1$ & 1752 & 66 & $W M-189$ & 431 & 63 & & & & & & & & 4160 \\
\hline $\mathrm{H}-\bar{i}$ & 10 & 7 & 83 & 383 & $y 1-1$ & $52+$ & 60 & WM-189 & 435 & 63 & & & & & & & & 4080 \\
\hline $\mathrm{H}-1$ & 10 & 7 & 83 & 384 & 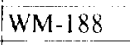 & $1727^{\circ}$ & 60. & WM-189 & 493 & 63 & & & & & & & & 4100 \\
\hline $\mathrm{H}-1$ & 11 & 7 & 83 & 385 & 100 & & 66 & WM-189 & 463 & $63 !$ & & & & & & & & +160 \\
\hline $\mathrm{H}-\mathrm{I}$ & 12 & 7 & 83 & 386 & $W M-188$ & 1700 & 60 & WM- 189 & 427 & 63 & & & & & & & & 4240 \\
\hline $\mathrm{H}-\mathrm{I}$ & 12 & 7 & 83 & 387 & $4-188$ & 1752 & $60 t$ & WM-189 & 506 & 63 & & & & & & & & 4240 \\
\hline $\mathrm{H}-\mathrm{I}$ & 13 & 7 & 83 & 388 & $W M-188$ & 1753 & & -189 & 408 & $63 i$ & & & & & & & & 4160 \\
\hline $\mathrm{H}-1$ & 13 & 7 & 83 & 389 & WM-188 & 1570 & 601 & WM-189 & 383 & 63 & & & & & & & & 3680 \\
\hline
\end{tabular}


Table A4. Calciner Feed to Calcined Solids Storage Facility IV. (continued)

\begin{tabular}{|c|c|c|c|c|c|c|c|c|c|c|c|c|c|c|c|c|c|c|}
\hline & & & & & & & & Fex & Streantll & & & & & & & old che & micals & \\
\hline NWCF & & Date & & Batch & & & & & 2 & & & 3 & & $\mathrm{Ali}$ & & $\mathrm{NaNO}_{3}$ & $\mathrm{H}_{3} \mathrm{BO}_{3}$ & $\left.\mathrm{Ca} \mathrm{NO}_{3}\right)_{2}$ \\
\hline Cump. & $d$ & ino & $\mathrm{yr}$ & $\bar{N}_{0}$. & tank & Eal & code & Lank & gal & code & lank & gal & $\cos \mathrm{d}^{2}$ & gal & $M$ & M & $h \underline{g}$ & lb \\
\hline $\mathrm{H}-1$ & 14 & 7 & 83 & 390 & $W^{\prime} M-188$ & 1016 & 06 & WM-1 $8^{\circ}$ & 479 & 03 & & & & & & & & +160 \\
\hline$H 1$ & 15 & 7 & 83 & $3 \overline{91}$ & WM-188 & 1805 & 60 & WM-189) & 490 & 03 & & & & & & & & 4400 \\
\hline
\end{tabular}


page intentionally blank

A-74 
Table A5. Calciner Feed to Calcined Solids Storage Facility V.

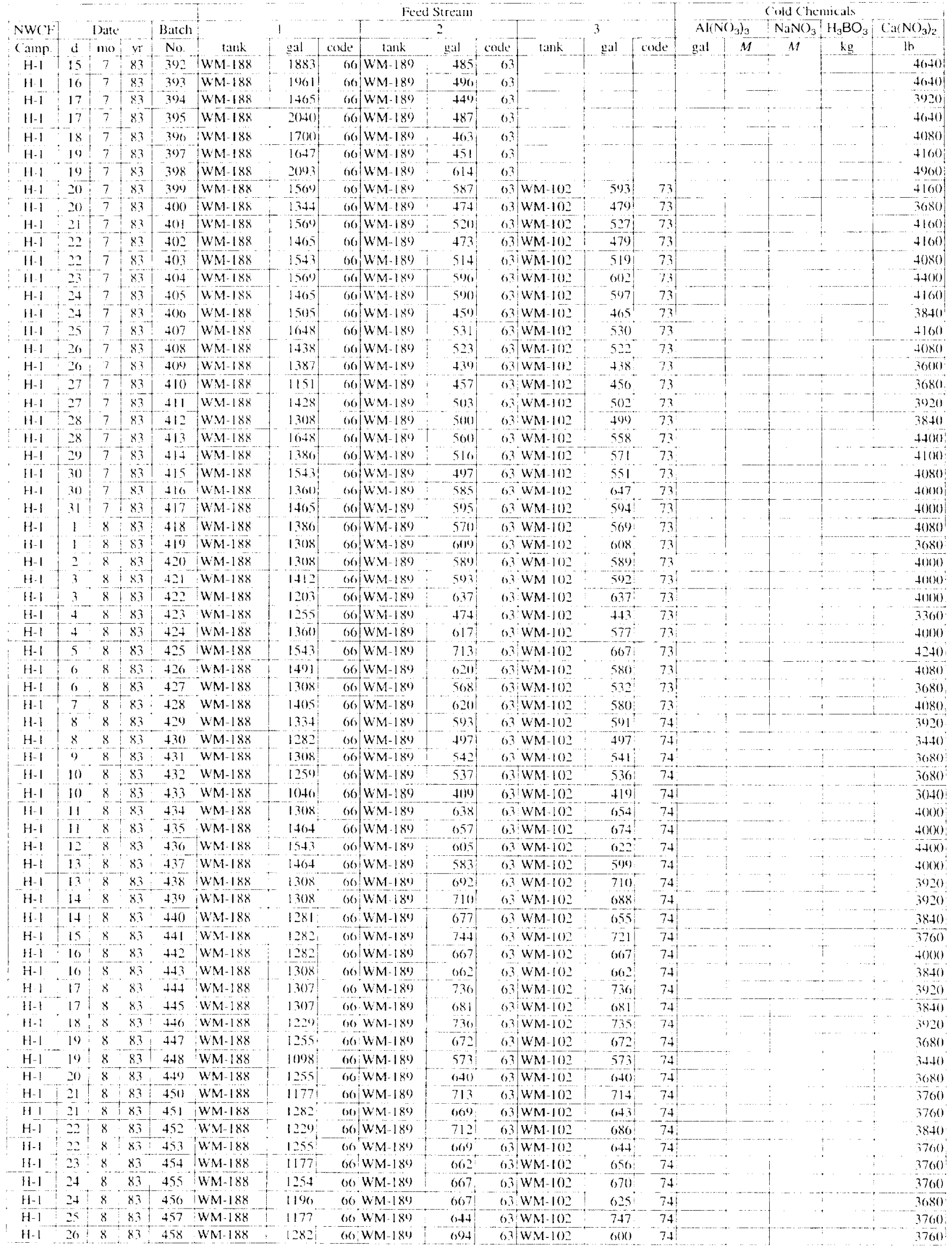


Table A5. Calciner Feed to Calcined Solids Storage Facility V. (continued)

\begin{tabular}{|c|c|c|c|c|c|c|c|c|c|c|c|c|c|c|c|c|c|}
\hline \multirow{3}{*}{$\begin{array}{l}\text { NWCF } \\
\text { Camp. }\end{array}$} & \multirow{2}{*}{\multicolumn{3}{|c|}{ Date }} & \multirow{3}{*}{$\begin{array}{c}\text { Batch } \\
\text { No. }\end{array}$} & \multicolumn{8}{|c|}{ Teed strum } & \multicolumn{5}{|c|}{ Cold Chemicals } \\
\hline & & & & & & 1 & & & 2 & & & 3 & AICNO & $\underline{3})_{3}$ & $\mathrm{NaNO}_{3}$ & $\mathrm{H}_{3} \mathrm{BO}_{3}$ & $\mathrm{Ca}\left(\mathrm{NO}_{3}\right)_{2}$ \\
\hline & d & mo & $\mathrm{ys}$ & & tank & gal & code & lank & gal & codet & tank & code & gal & $M$ & $M$ & $\mathrm{~kg}$ & $\mathrm{Jb}$ \\
\hline $\mathrm{H}-1$ & 20 & 8 & 83 & 459 & WM-188 & 1307 & 60 & WM-189 & 645 & 63 & WM-102 & 694 & & & & & 3840 \\
\hline $\mathrm{H}-\mathrm{I}$ & 27 & 8 & 83 & 460 & WM-188 & 1308 & 60 & WM-189 & 668 & 63 & WM-102 & 802 & & & & & 4160 \\
\hline $\mathrm{H}-1$ & 27 & 8 & 8.3 & 461 & WM-188 & 1020 & 60 & WM-189 & 733 & 03 & $W M-102$ & $595^{5^{-}}$ & & & & & 3200 \\
\hline $\mathrm{H}-1$ & 28 & 8 & 83 & 462 & $W M-188$ & 11251 & 60 & WM- 189 & $6 \times 2$ & 63 & $W \bar{M}-102$ & $735:$ & & & & & 3840 \\
\hline $\mathrm{H}-1$ & 29 & 8 & 8.3 & 463 & WM-188 & 1177 & 60 & $W M-189$ & 607 & 63 & $\overline{W M}-100$ & 667 & & & & & 3680 \\
\hline $\mathrm{H}-\mathrm{I}$ & 39 & 8 & 8.3 & 464 & $W M-188$ & 188.3 & 60 & WM-189 & 521 & 63 & & & & & & & $4+80$ \\
\hline $\mathrm{H}-1$ & 30 & 8 & 83 & 465 & WM-188 & 1883 & 60 & WM-189 & 494 & 0.3 & & & & & & & $4+80$ \\
\hline $\mathrm{H}-1$ & 30 & 8 & 83 & 460 & $W M-188$ & 1883 & 00 & WM-189 & 488 & $0 . t^{4}$ & & & & & & & +560 \\
\hline $\mathrm{H}-\mathrm{l}$ & 3 & 8 & 83 & 46.7 & WM-188 & 1909 & 60 & WM-189 & $5(6)$ & 03 & & & & & & & 4560 \\
\hline $\mathrm{H}-1$ & 1 & 9 & 83 & 468 & $W M-188$ & 1770 & 66. & WM-189 & 408 & 0.3 & & & & & & & $4+80$ \\
\hline $\mathrm{H}-\mathrm{I}$ & 1 & 9 & 8.7 & 469 & WM-188 & 1831 & 60 & WM-189 & $558 !$ & 63 & & & & & & & $4+80$ \\
\hline $\mathrm{H}-\mathrm{I}$ & 2 & ) & 8.3 & 470 & WM- 188 & 1936 & 60 & WM- 189 & 487 & $6 ?$ & & & & & & & 4560 \\
\hline $\mathrm{H}-\mathrm{I}$ & 2 & $y$ & 8. & $4 / 1$ & WM- 188 & 1909 & 60 & WM-1 $8^{\circ}$ & 353 & 63 & & & & & & & $4+80$ \\
\hline $\mathrm{H}-1$ & 3 & ) & $83 !$ & 472 & WM-187 & 2083 & 67 & WM-184 & 282 & $65 t$ & & & & & & & 7280 \\
\hline $\mathrm{H}-\mathrm{I}$ & 4 & 9 & 83 & 473 & WM-187 & 2186 & 67 & WM-184 & 248 & $65^{\circ}$ & & & & & & & 7280 \\
\hline $\mathrm{H}-\mathrm{I}$ & 5 & 9 & 83 & 474 & $W M-187$ & 2288 & 67 & WM-184 & 223 & 65 & & & & & & & $74+0$ \\
\hline $\mathrm{H}-1$ & 5 & 9 & 83 & 475 & WM-187 & 2083 & 67. & WM-184 & 280 & $05^{\circ}$ & & & & & & & 7120 \\
\hline $\mathrm{H}-\mathrm{I}$ & 6 & 9 & 83 & 476 & $W \bar{M}-187$ & $2 \overline{109}$ & 67 & WM-184 & 254 & $65^{\circ}$ & & & & & & & 7280 \\
\hline $\mathrm{H}-\mathrm{I}$ & 6 & 9 & 83 & 477 & $W M-187$ & 2132 & 67 & WM-184 & 233 & 05 & & & & & & & 7040 \\
\hline $\mathrm{H}-1$ & 7 & 9 & 83 & 478 & WM-187 & 2031 & 67 & $W M+184$ & 265 & 65 & & & & & & & 7040 \\
\hline $\mathrm{H}-\mathrm{I}$ & 8 & 9 & 83 & 479 & WM-187 & 2135 & 67 & $W M-184$ & 306 & $65^{+}$ & & & & & & & $0+80$ \\
\hline $\mathrm{H}-\mathrm{I}$ & 8 & 9 & 83 & $480^{\circ}$ & WM & 2058 & 67 & WM-184 & 263. & 65 & & & & & & & $66+0$ \\
\hline $\mathrm{H}-1$ & 9 & 9 & 83 & 481. & WM & 2100 & 67 & WM-184 & 278 & $65^{\dagger}$ & & & & & & & 6960 \\
\hline $\mathrm{H}-1$ & 10 & 9 & 83 & $482^{\circ}$ & WM-187 & 2212 & 67 & WM-184 & 244 & 6.5 & & & & & & & 0720 \\
\hline HI & $10^{-1}$ & 9 & 83 & 183 & WN & 2237 & 67 & $W M-184$ & 242 & 6.5 & & & & & & & 67201 \\
\hline $\mathrm{H}-1$ & 11 & 9 & 83 & 484 & WM-187 & 2314 & 67 & WM-184 & 247 & $65^{\circ}$ & & & & & & & 6320 \\
\hline $\mathrm{H}-1$ & 11 & 9 & 83 & 485 & WM-187 & $2160 !$ & 67 & WM-184 & $201^{\circ}$ & $05^{\circ}$ & & & & & & & $0+80$ \\
\hline $\mathrm{H}-1$ & 12 & () & 83 & 486 & WM-187 & 2597 & 67 & & & & & & & & & & 3240 \\
\hline $\mathrm{H}-1$ & 137 & 9 & 83 & 487 & WM-187 & 2545 & 67 & & & & & & & & & & 5760 \\
\hline $\mathrm{HI}$ & 11 & 9 & 83 & 488 & WM- 187 & 5494 & 67 & & & & & & & & & & 5920 \\
\hline $\mathrm{H}-\mathrm{I}$ & 15 & ) & 83 & 489 & WM-1 & 2391 & 67 & & & & & & & & & & 6000 \\
\hline $\mathrm{H}-\mathrm{I}$ & 15 & 9 & 83 & 490 & WM-1 & 2443 & 67 & & & & & & & & & & 6000 \\
\hline $\mathrm{H}-1$ & 16 & 9 & 83 & 491 & WM- 187 & 2263 & 67 & & & & & & & & & & 5760 \\
\hline $\mathrm{H}-\mathrm{l}$ & $17^{-1}$ & 6 & 83 & 402 & $w$ & 2005 & 67 & & & & & & & & & & 4880 \\
\hline $\mathrm{H}-1$ & 17 & 9 & 83 & 493 & $W M-1$ & 2180 & 67 & & & & & & & & & & 5520 \\
\hline $\mathrm{H}-1$ & $18 !$ & 9 & 83 & 404 & WM-187 & 2134 & 67 & & & & & & & & & & 5360 \\
\hline $\mathrm{H}-\mathrm{I}$ & $19:$ & 9 & 83 & 495 & WM-187 & 1941 & 67 & & & & & & & & & & 4800 \\
\hline $\mathrm{H}-1$ & $19:$ & 9 & 83 & 490 & WM-187 & 2000 & 67 & & & & & & & & & & 5280 \\
\hline $\mathrm{H}-\mathrm{I}$ & 20 & ) & 83 & 497 & WM-187 & 2185 & 67 & & & & & & & & & & 5280 \\
\hline $\mathrm{IH}-1$ & 21 & 9 & 83 & 498 & WM-187 & $1980 !$ & 67 & & & & & & & - & & & 4880 \\
\hline $\mathrm{H}-1$ & $22 !$ & 9 & 83 & 409 & WM-182 & 2133 & 68 & & & & & & & & & 54.5 & 880 \\
\hline $\mathrm{H}-\mathrm{I}$ & 22 & 9 & 83 & 500 & WM-182 & 2412 & 68 & & & & & & & & & 58.2 & $960 \mathrm{i}$ \\
\hline $\mathrm{H}-1$ & 23 & ) & 83 & 501 & WM -182 & 2412 & 68 & & & & & & & & & 57.3 & 960 \\
\hline $\mathrm{H}-1$ & 24 & 9 & 83 & 502 & WM-182 & 2056 & 68 & & & & & & & & & 50.5 & $800 !$ \\
\hline $\mathrm{H}-1$ & 25 & 9 & 83 & 5003 & WM-182 & 2235 & 68 & & & & & & & & & 50.5 & 800 \\
\hline $\mathrm{H}-1$ & 20 & 9 & 83 & 504 & $W M-182$ & 2260 & 68 & & & & & & & & & 55.0 & 880 \\
\hline $\mathrm{H}-\mathrm{I}$ & 27 & 9 & 83 & 505 & WM-182 & 2057 & 68 & & & & & & & & & 9.6 & 800 \\
\hline $\mathrm{H}-\mathrm{I}$ & 28 & 9 & 83 & 500 & WM-182 & 2031 & 68 & & & & & & & & & $9.6^{\circ}$ & 800 \\
\hline $\mathrm{H}-\mathrm{I}$ & 28 & 9 & 83 & 507 & WM-182 & 2073 & 68 & & & & & & & & & 22.5 & 800 \\
\hline $\mathrm{H}-\mathrm{I}$ & 21) & 9 & 83 & 508 & WM-182 & 2286 & 0.8 & & & & & & & & & 23.6 & 880 \\
\hline $\mathrm{H}-1$ & 30 & 9 & 83 & 509 & $W M-182$ & 1980 & 68 & & & & & & & & & 20.6 & 800 \\
\hline $\mathrm{H}-1$ & 1 & 10 & 83 & 510 & WM- 182 & 210 & $68:$ & & & & & & & & & 9.4 & 800 \\
\hline $\mathrm{H}-\mathrm{I}$ & 2 & 10 & 83 & 511 & $W M-182$ & 1981 & 08 & & & & & & & $\ldots$ & & 8.9 & 720 \\
\hline $\mathrm{H}-1$ & 2 & 10 & 83 & 512 & WM-182 & 1913 & 08 & & & & & & & & & 9.4 & $x(x)$ \\
\hline $\mathrm{H}-\mathrm{I}$ & 3 & 10 & 83 & 513 & $1-18$ & $218+1$ & 68 & & & & & & & & & 10.3 & $880^{\circ}$ \\
\hline $\mathrm{H}-1$ & 4 & 10 & 83 & 514 & 4-18 & 1828 & 68 & & & & & & & & & 9.3 & $800:$ \\
\hline $\mathrm{H}-1$ & 5 & 10 & 83 & 515 & WM-18 & 1727 & 68 & & & & & & & & & 98 & 040 \\
\hline $\mathrm{H}-\mathrm{I}$ & 6 & 10 & 83 & 516 & WM-18 & 1701 & 68 & & & & & & & & & 8.0 & 6040 \\
\hline $\mathrm{H}-1$ & 6 & 10 & 83 & 517 & WM-182 & 2083 & 68 & & & & & & & & & 9.4 & 800 \\
\hline $\mathrm{H}-1$ & 7 & 10 & 83 & 518 & & & & $W M-100$ & 2111 & 72 & & & & & & 10.0 & 160 \\
\hline $\mathrm{H}-1$ & 8 & 10 & 83 & 519 & & & & WM- 100 & 1550 & 72 & & & & & & 7.3 & 120 \\
\hline $\mathrm{H}-\mathrm{I}$ & 9 & 10 & 83 & 520 & & & & WM-10) & 1070 & 72 & & & & & & 6.0 & 100 \\
\hline $\mathrm{H}-\mathrm{I}$ & 10 & 10 & 83 & 521 & & & & $W M-100$ & 10801 & $72 \vdots$ & & & & & & 0.0 & $100 ?$ \\
\hline $\mathrm{H}-\mathrm{I}$ & 13 & 1 & 84 & 1010 & Cold & & & & & & & & 2515 & 2.2 & & 70.0 & \\
\hline $\mathrm{H}-1$ & 14 & 1 & 84 & $102 \mathrm{C}$ & Cold & & & & & & & & 2538 & 22 & & 70.0 & \\
\hline$H-1$ & 15 & 1 & 84 & 1036 & Cold & & & & & & & & 1297 & 2.2 & & 600 & \\
\hline$\overline{\mathrm{H}-1}$ & 10 & 1 & 84 & 522 & WM- 188 & 523 & 601 & WM-189 & $252 !$ & 63 & $W M-102$ & 252 & & & & & 2080 \\
\hline $\mathrm{H}-1$ & 17 & 1 & 84 & 523 & WM-188 & $710 !$ & 601 & $W M-189$ & $389]^{-}$ & $63 t$ & WM 102 & 3881 & & & & & 2400 \\
\hline
\end{tabular}


Table A5. Calciner Feed to Calcined Solids Storage Facility V. (continued)

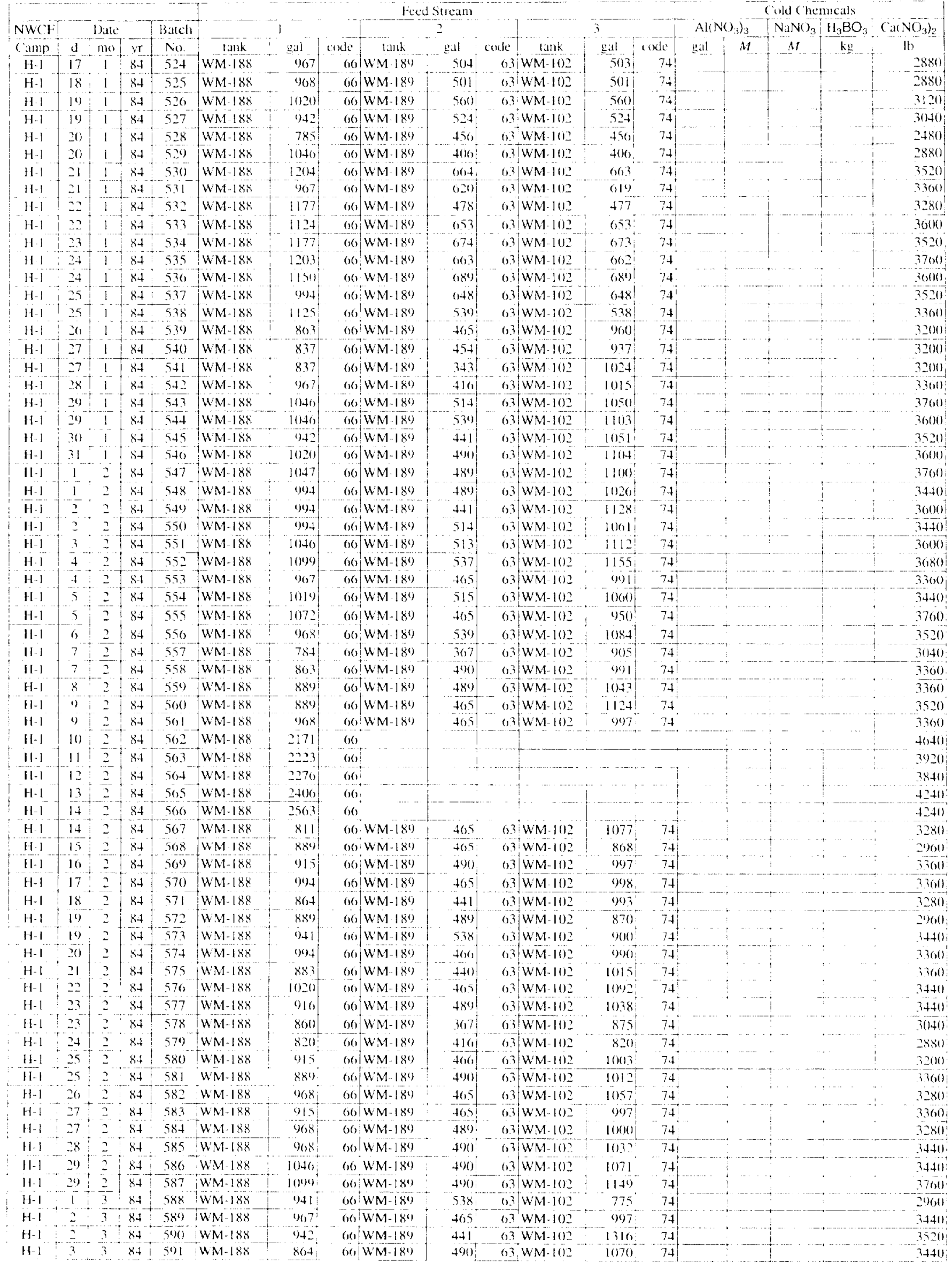


Table A5. Calciner Feed to Calcined Solids Storage Facility V. (continued)

\begin{tabular}{|c|c|c|c|c|c|c|c|c|c|c|c|c|c|c|c|c|c|}
\hline \multirow{2}{*}{\multicolumn{14}{|c|}{$[-$ Feed Sirean }} & \multirow{2}{*}{\multicolumn{4}{|c|}{ Cold Chenicals }} \\
\hline \multirow{3}{*}{$\begin{array}{l}\mathrm{NWCF} \\
\text { Camp }\end{array}$} & & & & & & & & & & & & & & & & & \\
\hline & \multicolumn{3}{|c|}{ Date } & Batch & & 1 & & & $\therefore$ & & & 3 & & All & & $\mathrm{NaNO}_{3}, \mathrm{H}_{3} \mathrm{BU}_{3}$ & $\mathrm{a}\left(\mathrm{NO}_{3}\right)_{2}$ \\
\hline & d & mo & $\mathrm{yr}$ & $\mathrm{No}$ & lank & gal & code & tank & gal & $\operatorname{cod} 0$ & lank & gal & code & gal & $M$ & $M$ & ib \\
\hline $\mathrm{H}-1$ & 4 & 3 & 84 & 502 & $W M-188$ & $830^{\dagger}$ & (6) & WM-189 & +90 & 63 & WM-102 & 1069 & 74. & & & & $3+400^{\circ}$ \\
\hline $\mathrm{H}-1$ & 4 & 3 & 84 & 593 & WM-188 & 1046 & 60 & WM-180 & 515 & 63 & WM-102 & 8881 & 74 & & & & 3280 \\
\hline $\mathrm{H}-1$ & 5 & 3 & 84 & 594 & WM-18X & 1020 & 60 & WM-189 & 514 & 63 & WM-102 & 900 & 74 & & & & 3520 \\
\hline $\mathrm{H}-\mathrm{I}$ & 5 & 3 & 84 & 595 & WM-188 & 904 & 60 & WM-189 & 490 & 63 & WM-102 & 1007 & 74 & & & & $3440:$ \\
\hline $\mathrm{H}-1$ & 6 & 3 & 84 & 596 & & & & & & & WM-102 & 2350 & 7.4 & & & 150 & $480^{\circ}$ \\
\hline $\mathrm{H}-1$ & 7 & 3 & 84 & 597 & & & & & & & WM-102 & 2100 & 74 & & & 12.5 & 480 \\
\hline $\mathrm{H}-1$ & 7 & 3 & 84 & 598 & & & & & & & $1 W M-102$ & 2720 & 74 & & & 13.7 & 500 \\
\hline $\mathrm{H} \cdot 1$ & 8 & 3 & 84 & 599 & & & & & & & $\mathrm{WM}-102$ & 200010 & 74 & & & 14.0 & 480 \\
\hline $\mathrm{H}-1$ & 9 & 3 & 84 & 600 & & & & & & & $W M-102$ & 2250 & 74 & & & 13.0 & 480 \\
\hline $\mathrm{H}-1$ & 9 & 3 & 84 & 601 & & & & & & & WM-102 & 1975 & 74 & & & 12.7 & 400 \\
\hline $\mathrm{H}-1$ & 10 & 3 & 84 & 002 & & & & & & & WM-102 & 1710 & 74 & & & 10.1 & 320 \\
\hline $\mathrm{H}-1$ & 10 & 3 & 84 & 603 & & & & & & & $W \mathrm{M}-102$ & 1677 & 74 & & & 10.2 & 320 \\
\hline $\mathrm{H}-1$ & 11 & 3 & 84 & 604 & WM-1 88 & 915 & 66 & WM-189 & 538 & 63. & WM-102 & 900 & 74 & & & & 3300 \\
\hline $\mathrm{H}-1$ & 11 & 3 & 84 & 605 & $W M-188$ & $9_{4}$ & 60 & WM-189 & 465 & 63 & $W M-102$ & 825 & 74 & & & & 3440 \\
\hline $\mathrm{H}-1$ & 12 & 3 & 84 & 606 & WM 188 & 785 & 60 & $W M-180$ & $480^{\circ}$ & 631 & $W M-102$ & 937 & 74 & & & & 3120 \\
\hline $\mathrm{H}-1$ & 13 & 3 & 84 & 607 & WM- 188 & 785 & 66 & $W M-189$ & 343 & $63^{3}$ & WM-102 & 903 & 74 & & & & 2800 \\
\hline $\mathrm{H}-1$ & 13 & 3 & 84 & 608 & WM- 188 & 1020 & 66 & WM-184 & 465 & 631 & WM-102 & 1042 & 74 & & & & 3280 \\
\hline $\mathrm{H}-1$ & 14 & 3 & 84 & 609 & WM- 188 & 908 & $06 !$ & WM-18! & $4+6 !$ & 63 & $W M-102$ & 988 & 74 & & & & 3280 \\
\hline $\mathrm{H}-1$ & 15 & 3 & 84 & 610 & WM-188 & 706 & 66 & WM-189 & $440^{\circ}$ & 0.31 & $W M-102$ & 1101 & 74 & & & & 3280 \\
\hline $\mathrm{H} \mathrm{I}$ & 15 & 3 & 84 & 611 & WM- 188 & 889 & $60:$ & WM-1 80 & 405 & 6.31 & WM-102 & 850 & 74 & & & & 3300 \\
\hline $\mathrm{H}-1$ & 16 & 3 & 84 & 612 & $W M-188$ & 942 & 66 & WM 189 & $4 \%$ & 63 & WM- 102 & 971 & 74 & & & & 3360 \\
\hline $\mathrm{H}-1$ & 16 & 3 & 84 & 613 & & & $\vdots$ & & & & $W M-102$ & 2209 & 74 & & & 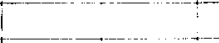 & 1080 \\
\hline $\mathrm{H}-\mathrm{I}$ & 10 & 4 & 84 & $\mathrm{DB}$ & Dolomite B & d approx & $x .1000$ & cubic fect) & & & & 7014 ? & 92 & & & & \\
\hline $\mathrm{H}-1$ & 17 & 4 & 84 & $001 \mathrm{C}$ & Cold & & & & & & & & & 3175 & 2 & 14.9 & \\
\hline H-1 & 18 & 4 & 84 & $D B$ & Dolonite is & d (upprox & x. $15 \mathrm{cu}$ & ubic fect & & & & 1052 & $\sqrt{2}$ & & & & \\
\hline $\mathrm{H}-1$ & 18 & 4 & 84 & $002 C$ & Cold & & & & & & & & & 1600 & 2.2 & $7 \overline{5}$ & \\
\hline $\mathrm{H}-1$ & 20 & 4 & 84 & 614 & & & & $W M-189$ & 734 & 70 & WM & 1350 & 74 & & & & 2080 \\
\hline $\mathrm{H}-1$ & 21 & 4 & 84 & 615 & & & & WM-189 & 636 & 70 & WN & 1600 & 74 & & & & 2000 \\
\hline $\mathrm{H}-1$ & 21 & 4 & 84 & 616 & & & & WM-189 & 734 & 70 & WM & 1450 & 74 & & & & 2080 \\
\hline $\mathrm{H}-1$ & 22 & 4 & 84 & 617 & & & & $W M-189$ & 808 & 70 & 102 & 1000 & 74 & & & & 2160 \\
\hline $\mathrm{H}-\mathrm{I}$ & 22 & 4 & 84 & 618 & & & & WM-189 & 734 & 70 & $W M-102$ & 1550 & 74 & & & & 2160 \\
\hline $\mathrm{H}-1$ & 24 & 4 & 84 & 619 & & & & $W M-189$ & $700{ }^{\dagger}$ & 70 & WM-102 & 1550 & 74 & & & & 1080 \\
\hline $\mathrm{H}-\mathrm{I}$ & 24 & 4 & 84 & 620 & & & & WM-189 & 1127 & 70 & $W M-102$ & 1850 & 74 & & & & 2160 \\
\hline $\mathrm{H}-\mathrm{I}$ & 25 & 4 & 84 & 621 & & & & WM-189 & 826 & 70 & WM- & 1.500 & $74^{t}$ & & & & 1760 \\
\hline $\mathrm{H}-\mathrm{I}$ & 26 & 4 & 84 & 622 & & & & WM-189 & $1120 !$ & $70)^{1}$ & $W M$ & 1850 & 74 & & & & 2160 \\
\hline $\mathrm{H}-1$ & 26 & 4 & 84 & 623 & & & & $W M-189$ & 571 & $70 \dagger$ & WM-102 & 2260 & 74 & & & & 20100 \\
\hline $\mathrm{H}-1$ & 27 & 4 & 84 & 624 & & & & WM-189 & 6.57 & 701 & WN & 2400 & 74 & & & & 2240 \\
\hline $\mathrm{H}-1$ & 28 & 4 & 84 & 625 & & & & WM-189 & 528 & 70 & WI & 1765 & 74 & & & & 1840 \\
\hline $\mathrm{H}-1$ & 28 & 4 & 84 & 626 & & & & $W M-189$ & 530 & 70 & Wh & 1900 & 74 & & & & 1840 \\
\hline $\mathrm{H}-\mathrm{I}$ & 29 & 4 & $x+$ & 621 & & & & WM-189 & 576 & 70 & WM-102 & 2450 & 74 & & & & 2240 \\
\hline $1-1$ & 21) & 4 & 84 & 628 & & & & WM-189 & 495 & 70 & WM-102 & 1950 & 74 & & & & 1840 \\
\hline $\mathrm{H}-1$ & 30 & 4 & 84 & 629 & & & & & & & WM-10? & 2430 & $74^{t}$ & & & & $1+40^{\circ}$ \\
\hline $\mathrm{H}-\mathrm{I}$ & 30 & 4 & 84 & 630 & & & & & & & WM-102 & 2100 & 74 & & & & 1280 \\
\hline $\mathrm{H}-1$ & 1 & 5 & 84 & 631 & & & & & & & WM-102 & 2800 & 74 & & & & 1600 \\
\hline $\mathrm{H}-1$ & 1 & 5 & 84 & 632 & & & & & & & WM $10 ?$ & 2501 & 74 & & & & 1600 \\
\hline H1-1 & 3 & 5 & 84 & $633^{-}$ & & & & & & & WM-102 & 2808 & 74 & & & & 1600 \\
\hline $\mathrm{H}-1$ & 3 & 5 & 84 & 634 & & & & & & & $W M-102$ & 609 & 74 & & & & 400 \\
\hline $\mathrm{H}-1$ & 3 & 5 & 84 & 635 & & & & WM-189 & 392 & 70 & WM-102 & 1850 & 74 & & & & $\mid 6001$ \\
\hline $\mathrm{H}-1$ & 4 & 5 & 84 & 636 & & & & WM- 189 & 472 & 70 & -102 & 50 & 74 & & & & 1520 \\
\hline $11-1$ & 4 & 5 & 84 & 6 & & & & $W M-189$ & $5+3$ & 76 & W & 20000 & 74 & & & & 1600 \\
\hline $\mathrm{H}-1$ & 5 & 5 & 84 & 638 & & & & WM-189 & 496 & 70 & WM-102 & 1950 & 74 & & & & 1760 \\
\hline $\mathrm{H}-\mathrm{I}$ & 5 & 5 & 8.4 & 639 & & & & WM-189 & 492 & $7 0 \longdiv { 1 }$ & $W M-102$ & $1900:$ & 74 & & & & 1680 \\
\hline $\mathrm{H}-1$ & 6 & 5 & 84 & 040 & & & & WM-189 & 475 & $70)$ & 102 & 1850 & 74 & & & & 15201 \\
\hline $\mathrm{H}-\mathrm{I}$ & 6 & 5 & 84 & 041 & & & & WM-189 & $6014]^{-}$ & $70 \Gamma$ & $W M-102$ & 2151 & 74 & & & & 17601 \\
\hline H-1 & 7 & 5 & 84 & 642 & & & & WM-189 & 57)! & 701 & $W M-102$ & 2050 & $74^{\circ}$ & & & & 1700 \\
\hline $\mathrm{H}-\mathrm{i}$ & 8 & 5 & $\overline{8}$ & & & & & $W M-189$ & 5751 & 701 & $W M-102$ & 1850 & 74 & & & & $1600^{\circ}$ \\
\hline $\mathrm{H}-1$ & 8 & 5 & 8.4 & $6+4$ & & & & WM-189 & $54 ?$ & 701 & $\overline{W M}-i n ?$ & 1800 & 74 & & & & 1520 \\
\hline $\mathrm{H}-\mathrm{l}$ & 9 & 5 & 84 & $6+5$ & & & & $W M-189$ & 475 & 701 & WM-102 & 1540 & $74 !$ & & & & 1280 \\
\hline $\mathrm{H}-\mathrm{I}$ & 9 & 5 & 84 & 640 & & & & WM- 189 & 511 & 70 & $W M-102$ & $1650^{\circ}$ & $74^{\circ}$ & & & & $1300:$ \\
\hline $\mathrm{H}-1$ & 10 & 5 & 84 & 647 & & & & WM-189 & 505 & $70 t$ & $W M-102$ & 1520 & 74 & & & & 1440 \\
\hline $\mathrm{H}-\mathrm{I}$ & 10 & 5 & 84 & 648 & & & & $W M-189$ & 476 & 701 & $W M-102$ & $1700^{\circ}$ & $74 !$ & & & & $1440:$ \\
\hline $\mathrm{H}-\mathrm{I}$ & 11 & 5 & 84 & 649 & & & & & & & WM-102 & 20093 & 74 & & & & 4720 \\
\hline $\mathrm{H}-\mathrm{I}$ & 12 & 5 & 84 & 650 & & & & & & & WM-102 & 2249 & 741 & & & & 4080 \\
\hline $\mathrm{H}-1$ & 12 & 5 & 84 & 651 & & & & & & & WM-102 & 2746 & 74 & & & & 4480 \\
\hline $\mathrm{H}-1$ & 13 & 5 & 84 & 652 & & & & & & & WN & 2301 & 74 & & & & 4000 \\
\hline $\mathrm{H}-1$ & 14 & 5 & 84 & 653 & M-187 & 1157 & 67 & WM-189 & 972 & 70 & & & & & & & 5280 \\
\hline $\mathrm{H}-1$ & 14 & 5 & 84 & 6.54 & WM-187 & 1697 & 67 & WM-189 & 1002 & 70 & & & & & & & 5760 \\
\hline $\mathrm{H}-\mathrm{I}$ & 15 & 5 & 84 & 655 & WM.187 & 1416 & 67 & WM-189 & 1072 & $700^{\circ}$ & & & & & & & 5300 \\
\hline
\end{tabular}


Table A5. Calciner Feed to Calcined Solids Storage Facility V. (continued)

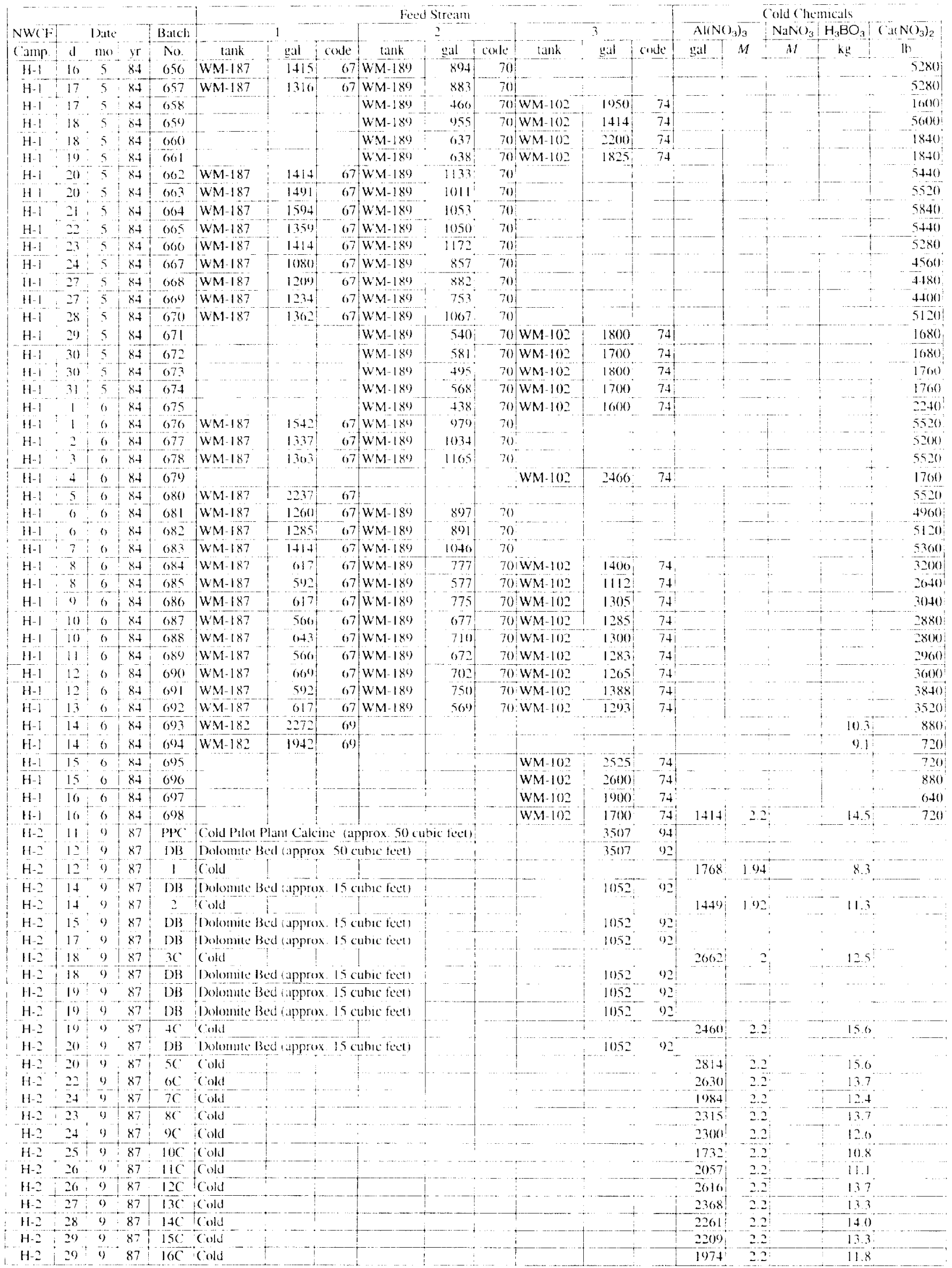


Table A5. Calciner Feed to Calcined Solids Storage Facility V. (continued)

\begin{tabular}{|c|c|c|c|c|c|c|c|c|c|c|c|c|c|c|c|c|c|}
\hline \multirow{3}{*}{$\begin{array}{l}\text { NWCF } \\
\text { Camp. }\end{array}$} & \multirow{2}{*}{\multicolumn{3}{|c|}{ Datt }} & \multirow{3}{*}{$\begin{array}{l}\text { Batch } \\
\text { No. }\end{array}$} & \multicolumn{8}{|c|}{ Feed Stream } & \multicolumn{5}{|c|}{ Cold Chemicals } \\
\hline & & & & & & 1 & & & 2 & & & 3 & $\operatorname{Al}(\mathrm{NC}$ & & $\mathrm{NaNO}_{3}$ & $\mathrm{H}_{3} \mathrm{BO}_{3}$ & $\mathrm{Cu}\left(\mathrm{NO}_{3}\right)_{2}$ \\
\hline & $\mathrm{d}$ & mo & $\mathrm{yT}_{\mathrm{T}}$ & & tank & gial & code & tunk & gal & code & lank & code & gal & $M$ & $M$ & $\mathrm{~kg}$ & ib \\
\hline $\mathrm{H}-2$ & 30 & 9 & 87 & 1 & WM-187 & 2372 & 75 & & & & & & 321 & 2.2 & & & 5080 \\
\hline $\mathrm{H}-2$ & 2 & 10 & 87 & 2 & WM-187 & 2.340 & 75 & & & & & & & & & & 5520 \\
\hline $\mathrm{HI}-2$ & 2 & 10) & 87 & 3 & WM-187 & 2137 & 75 & & & & & & & & & & 4720 \\
\hline $\mathrm{H}-2$ & 3 & $10:$ & 87 & 4 & WM-187 & $2150)^{+}$ & 75 & & & & & & 3507 & 2.2 & & & 4720 \\
\hline $\mathrm{H}-2$ & 3 & 10 & 87 & 5 & WM-187 & 21721 & 75 & & & & & & 100 & 2.21 & & & 5200 \\
\hline $\mathrm{H}-2$ & 4 & 10) & 87 & 6 & WM-187 & 2115 & 75 & & & & & & $198:$ & 2.2 & & & $46 \overline{40}$ \\
\hline $\bar{H}-2$ & 5 & 10 & 87 & 7 & WM-187 & 2256 & 75 & & & & & & 174 & 22 & & & 5360 \\
\hline $11-2$ & 5 & 10 & 87 & 8 & WM-187 & 2320 & 75 & & & & & & & & & & 5040 \\
\hline $\mathrm{H}-2$ & 0 & 10) & 87 & 9 & WM-187 & 2100 & 75 & & & & & & & & & & 4560 \\
\hline$H-2$ & 7 & 10 & 87 & 10 & WM-187 & 2229 & 75 & & & & & & & & & & 4880 \\
\hline $\mathrm{H}-2$ & 7 & 10 & 87 & 11 & WM-187 & 2170 & 75 & & & & & & & & & & 4720 \\
\hline $\mathrm{H}=2$ & 8 & 10 & 87 & 12 & WM-187 & 2047 & 75 & & & & & & & & & & 4080 \\
\hline $\mathrm{H}-2$ & 8 & 10 & 87 & 13 & WM-187 & 2430 & 75 & & & & & & & & & & 4880 \\
\hline $\mathrm{H}-2$ & (9) & 10) & 87 & 14 & WM-187 & 2246 & 75 & & & & & & & & & & 4496 \\
\hline $\mathrm{H}-2$ & 10 & 10 & 87 & 15 & WM-187 & 2204 & 75 & & & & & & & & & & 4400 \\
\hline $\mathrm{H}-2$ & 10 & 10 & 87 & 16 & WM-189 & 1907 & $77 !$ & WM-180 & 205 & 76 & & & & & & & 5360 \\
\hline $\mathrm{H}-2$ & 11 & 10 & 87 & 17 & WM-189) & 2040 & 77 & WM-186 & 215 & 76 & & & & & & & 5704 \\
\hline $11-2$ & 11 & 10 & 87 & 18 & WM-180 & 1928 & 77 & WM-180 & 232 & 76 & & & & & & & 6400 \\
\hline $\mathrm{H}-2$ & 12 & 10 & 87 & 19 & (WM-189) & 2197 & 77 & WM-186 & 210 & 76 & & & & & & & 6160 \\
\hline $\mathrm{H}-2$ & 13 & 10 & 87 & 20 & WM-189 & 1947 & 77 & WM-180 & 211 & 76 & & & & & & & 5440) \\
\hline $\mathrm{H}-2$ & 14 & 10 : & 87 & 21 & WM-189) & 2209 & 77 & WM-180 & 297 & 76 & & & & & & & $(4480$ \\
\hline $\mathrm{H}-2$ & 14 & 10 & 87 & 22 & WM-189) & 1960 & 77 & WM-180 & 225 & $76 !$ & & & & & & & 5520 \\
\hline $\mathrm{H}-2$ & 15 & II & 87 & 23 & WM-189 & 1798 & 77. & WM-180 & 195 & 76 & & & & & & & 5040 \\
\hline $\mathrm{H}-2$ & 15 & 10 & 87 & 24 & WM-189) & 2132 & 77 & WM- 180 & 240 & 76 & & & & & & & $6+80$ \\
\hline $\mathrm{H}-2$ & 16 & 10 & 87 & 25 & WM & 1972 & 77 & WM-180 & 219 & 76 & & & & & & & 6000 \\
\hline $\mathrm{H}-2$ & 17 & 10 & 87 & 20 & WM-189 & 2175 & 77 & WM-186 & 275 & 76 & & & & & & & $6040]$ \\
\hline $\mathrm{H}-\mathrm{Z}$ & 17 & 10 & 87 & 27 & WM-189) & 2283 & 77 & WM-186 & 373 & 76. & & & & & & & $6060)$ \\
\hline $\mathrm{H}-2$ & 18 & 10 & 87 & 28 & WM-189 & 1885 & $m$ & $W M-186$ & 337 & 76 & & & & & & & 0240 \\
\hline $\mathrm{H}-2$ & 19 & 10 & 87 & 20) & WW 180 & 1902 & 77 & WM 186 & 213 & $76:$ & & & & & & & 6000 \\
\hline $\mathrm{H}-2$ & 20 & 10 & 87 & 30) & WM-181) & 2001 & 77 & WM-180 & 375 & 76 & & & & & & & 6320 \\
\hline $\mathrm{H}-2$ & 20 & 10) & 87 & 31 & WM-189 & 2156 & 77 & WM-186 & $2955^{-}$ & $766^{\circ}$ & & & & & & & 0.560 \\
\hline $\mathrm{H}-2$ & 21 & 10 & 87 & 32 & WM-189 & $1673\}$ & 77 & WM-186 & 302 & 76 & & & & & & & 4720 \\
\hline $\mathrm{H}-2$ & 22 & 10 & 87 & 33 & WM-189 & 1409 & 77 & WM-186 & 277 & 76 & & & & & & & 4240 \\
\hline $11-2$ & 23 & 10 & 87 & 34 & WM-189 & 16921 & 77 & $\overline{\mathrm{W}} \mathrm{M}-186$ & 322 & 76 & & & & & & & 4960 \\
\hline $\mathrm{H}=2$ & 23 & 10 & $87 !$ & 35 & WM-180 & 18221 & 77 & WM-186 & 325 & 76 & & & & & & & 5200 \\
\hline $\mathrm{H}-2$ & 24 & 10 & 87 & 36 & WM-189 & 1700 & 77 & WM-186 & 307 & 76 & & & & & & & 5120 \\
\hline $\bar{H}-2$ & 24 & 10 & 87 & 37 & WM-189 & $1763^{\circ}$ & 77 & WM-180 & 304 & 76 & & & & & & & $4960:$ \\
\hline $\mathrm{H}-2$ & 25 & 10 & 87 & 38 & WM-189 & 1804 & 77 & WM-186 & 2811 & 76 & & & & & & & 5360 \\
\hline $\mathrm{H}-2$ & 25 & 10 & 87 & 39 & WM-189 & 1805 & 77 & WM-186 & 292 & 76 & & & & & & & 5120 \\
\hline $\mathrm{H}-2$ & 26 & 10 & 87 & 10 & WM-189 & 1653 & 77 & $W M-186$ & $201]^{-}$ & $70^{\circ}$ & & & & & & & 1720 \\
\hline $\mathrm{H}-2$ & 27 & 10) & 87 & 41 & WM-189 & 14251 & 77 & $W M-186$ & 275 & 76 & & & & & & & +320 \\
\hline $11-2$ & 28 & 10 & $87 !$ & 42 & WM-189 & $\mid 468$ & 77 & WM-186 & 256 & 76 & & & & & & & 4160 \\
\hline $\mathrm{H}-2$ & 28 & 101 & 87 & 43 & WM-189 & $1476 !$ & 77 & WM-186 & 263 & $76^{\circ}$ & & & & & & & $4560)$ \\
\hline$H-2$ & 30 & 10) & 87 & 44 & WM-189 & 16.51 & 77 & WM-186 & 305 & 76 & & & & & & & 4960 \\
\hline $11-2$ & 9 & 11 & 87 & 45 & WM-189 & 1696 & 771 & WM-186 & 315 & 76 & & & & & & & 5120 \\
\hline$H-2$ & 10) & 11 & 87 & 46 & WM-189 & 1700 & 77 & WM-180 & 321 & $76 !$ & & & & & & & 5360 \\
\hline $\mathrm{H}-2$ & 10 & 11 & 87 & 47 & $1-189$ & $180 \%$ & $77 !$ & WM-1 & 3114 & 76 & & & & & & & 5120 \\
\hline $\mathrm{H}-2$ & 11 & 11 & 87 & 48 & $4-189$ & 390 & 77 & WM-186 & $188:$ & 76 & & & & & & & $3962 !$ \\
\hline $\mathrm{H}-2$ & 12 & 11 & $87 !$ & 49 & $1-189$ & $745_{i}$ & 77. & WM-18 & 284. & 76 & & & & & & & $1960:$ \\
\hline $11-2$ & 1.3 & 11 & 87 & 50 & WM-189 & 1603 & 77 & WM-186 & 269 & 76 & & & & & & & $+960)$ \\
\hline $\mathrm{H}-2$ & 14 & 11 & 87 & 51 & WM-189 & 1642 & 77 & WM-186 & 301 & 76 & & & & & & & $4(140$ \\
\hline$H-2$ & 14 & 11 & 87 & 52 & $1-189$ & 1705 & 77. & WM-186 & 293 & 76 & & & & & & & 4400 \\
\hline$H-2$ & 15 & 11 & 87. & 53 & WM-189 & 1603 & 77 & WM-180 & 290 & $76 !$ & & & & & & & 4720 \\
\hline $\mathrm{H}-2$ & 16 & 11 & 87 & 54 & WM-189 & 1687 & 77 & WM-186 & 288 & $76^{i}$ & & & & & & & 4800 \\
\hline $1 \mathrm{H}-2$ & 17 & 11 & 87 & 55 & WM-189 & 1704 & 77 & & 305 & 70 & & & & & & & $5040)$ \\
\hline $\mathrm{H}-2$ & 18 & 11 & 87 & 50 & WM-189 & 1095 & 77 & WM-180 & $280^{\circ}$ & 76 & & & & & & & 4800 \\
\hline $\mathrm{H}-2$ & 18 & 11 & 87 & 57 & $W \bar{M}-189$ & 1818 & $77 \%$ & WM-18 6 & 314 & 76 & & & & & & & 5136 \\
\hline $\mathrm{H}-2$ & 19 & 11 & 87 & 58 & WM-189 & 1792 & 77 & WM-180 & 313 & 76 & & & & & & & $5(4) 40$ \\
\hline $\mathrm{H}-2$ & 20 & 11 & 87 & 59) & WM-189 & 1821 & 77 & $W M-186$ & 282 & 76 & & & & & & & 4480 \\
\hline $\mathrm{H}-2$ & 20 & 11 & 87 & 60 & $(1-180$ & 1502 & $77 !$ & WM-18 & 304 & 76. & & & & & & & $5300)$ \\
\hline $\mathrm{H}-2$ & 21 & 11 & 87 & 61 & WM-189) & 1533 & 77 & WM-186 & 267 & 76 & & & & & & & 4320 \\
\hline $\mathrm{H}-2$ & 22 & $1 !$ & 87 & 62 & WM-189 & 1829 & $77 !$ & WM-186 & 306 & 76 & & & & & & & 5200 \\
\hline $\mathrm{H}-2$ & 22 & 11 & 87 & 63 & WM-180 & 533 & 771 & WM-186, & 307 & 76 & & & & & & & 4960 \\
\hline $\mathrm{H}-2$ & 23 & II & 87 & 64 & WM-189 & 1733 & $77 !$ & WM-180 & 303 & $76 !$ & & & & & & & 4880 \\
\hline $\mathrm{H}-2$ & 23 & 11 & 871 & 65 & WM-189 & 1725 & 77 & WM-186 & 280 & 76 & & & & & & & 4880 \\
\hline $\mathrm{H}=2$ & 24 & 11 & 87 & 60 & WM-189 & 1625 & 771 & WM-186 & 317 & 76 & & & & & & & 5120 \\
\hline $\mathrm{H}-2$ & 25 & 11 & 87 & 67 & WM-189 & $1710 !$ & $77 !$ & WM-186 & 291 & 76 & & & & & & & 4880 \\
\hline $\mathrm{H}-2$ & 25 & 11 & 87 & 68 & WM-189 & $1648:$ & 77 & WM- 180 & $3 \geq 1$ & 76 & & & & & & & 4640 \\
\hline
\end{tabular}


Table A5. Calciner Feed to Calcined Solids Storage Facility V. (continued)

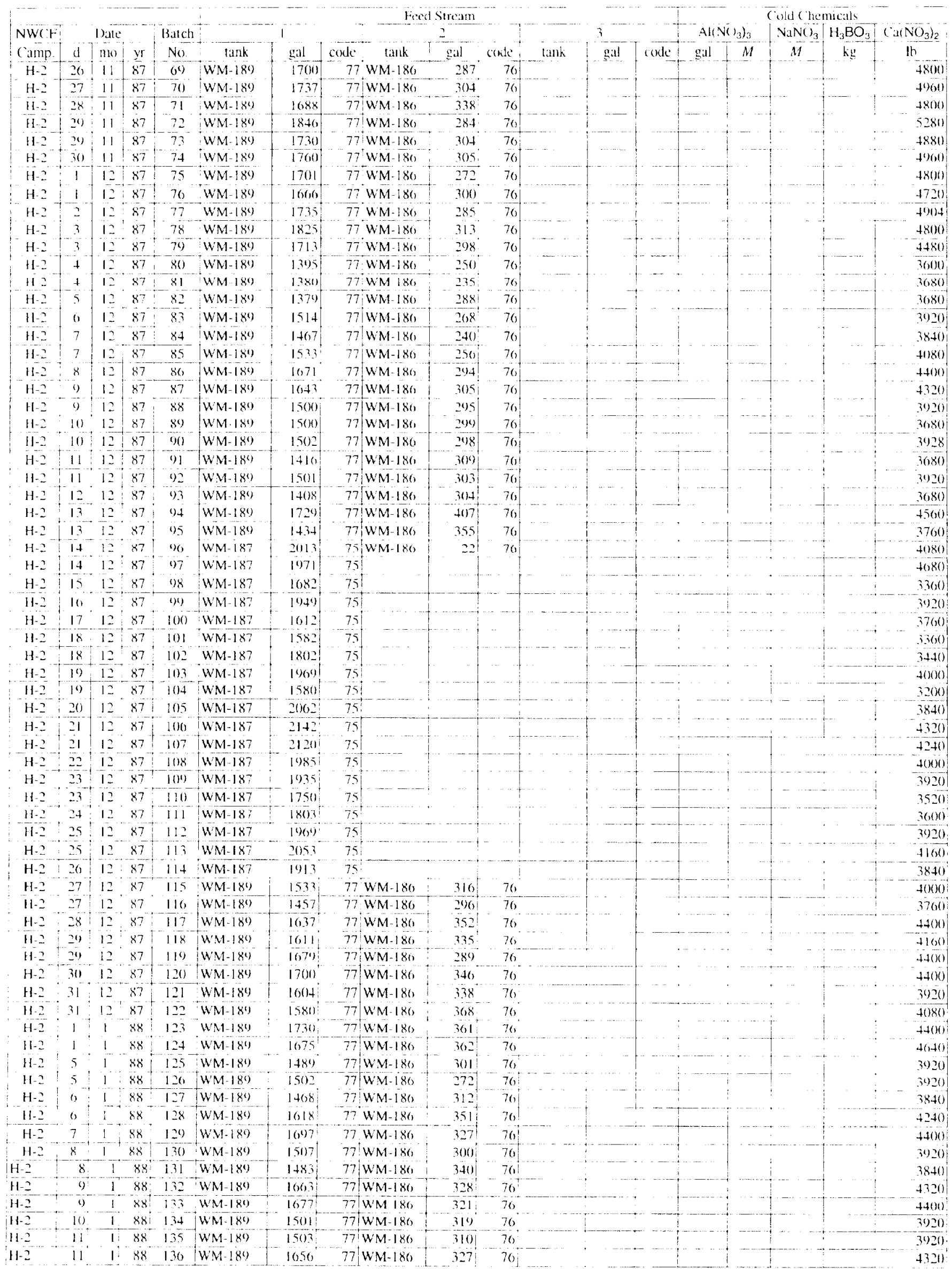


Table A5. Calciner Feed to Calcined Solids Storage Facility V. (continued)

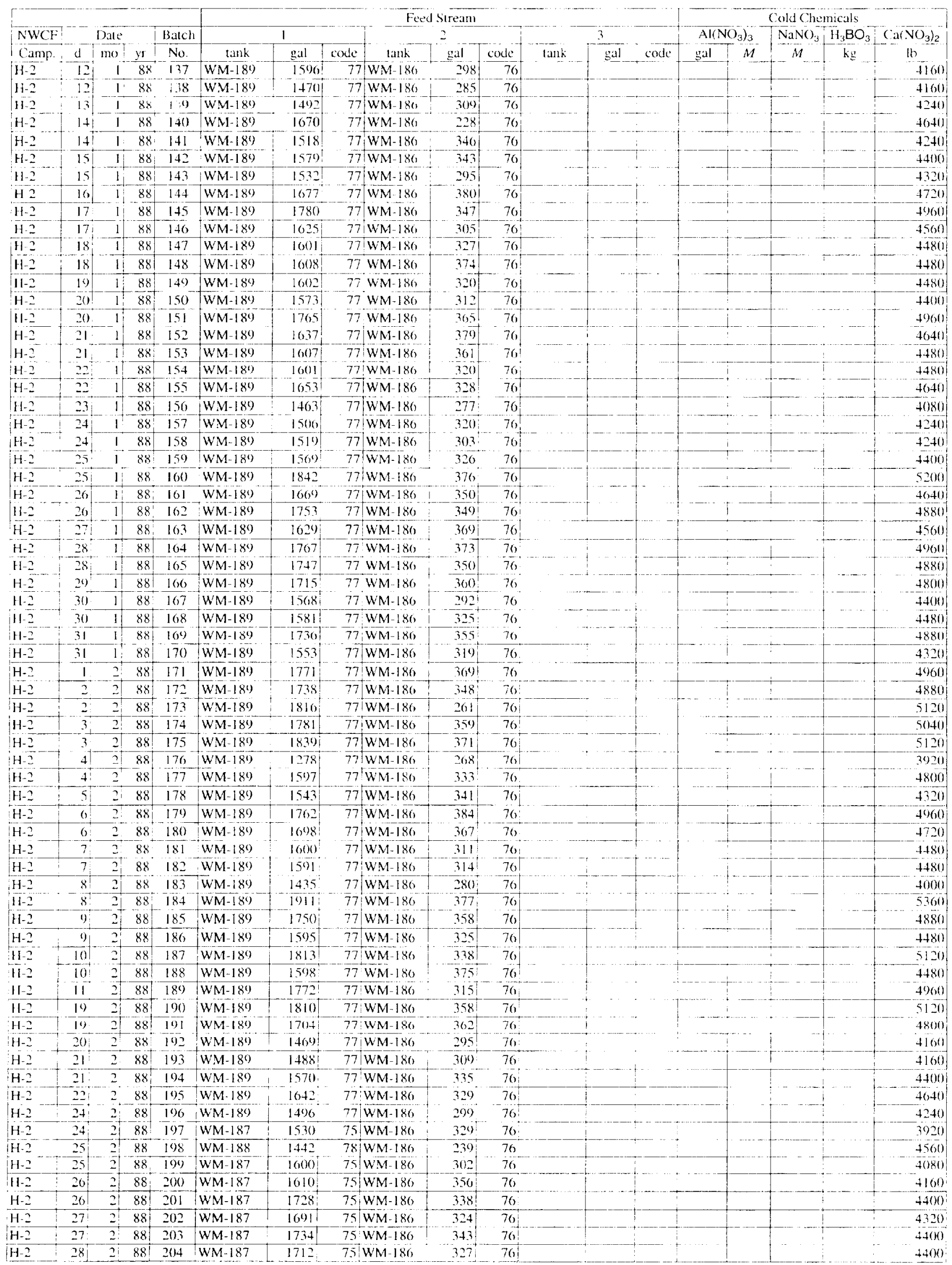


Table A5. Calciner Feed to Calcined Solids Storage Facility V. (continued)

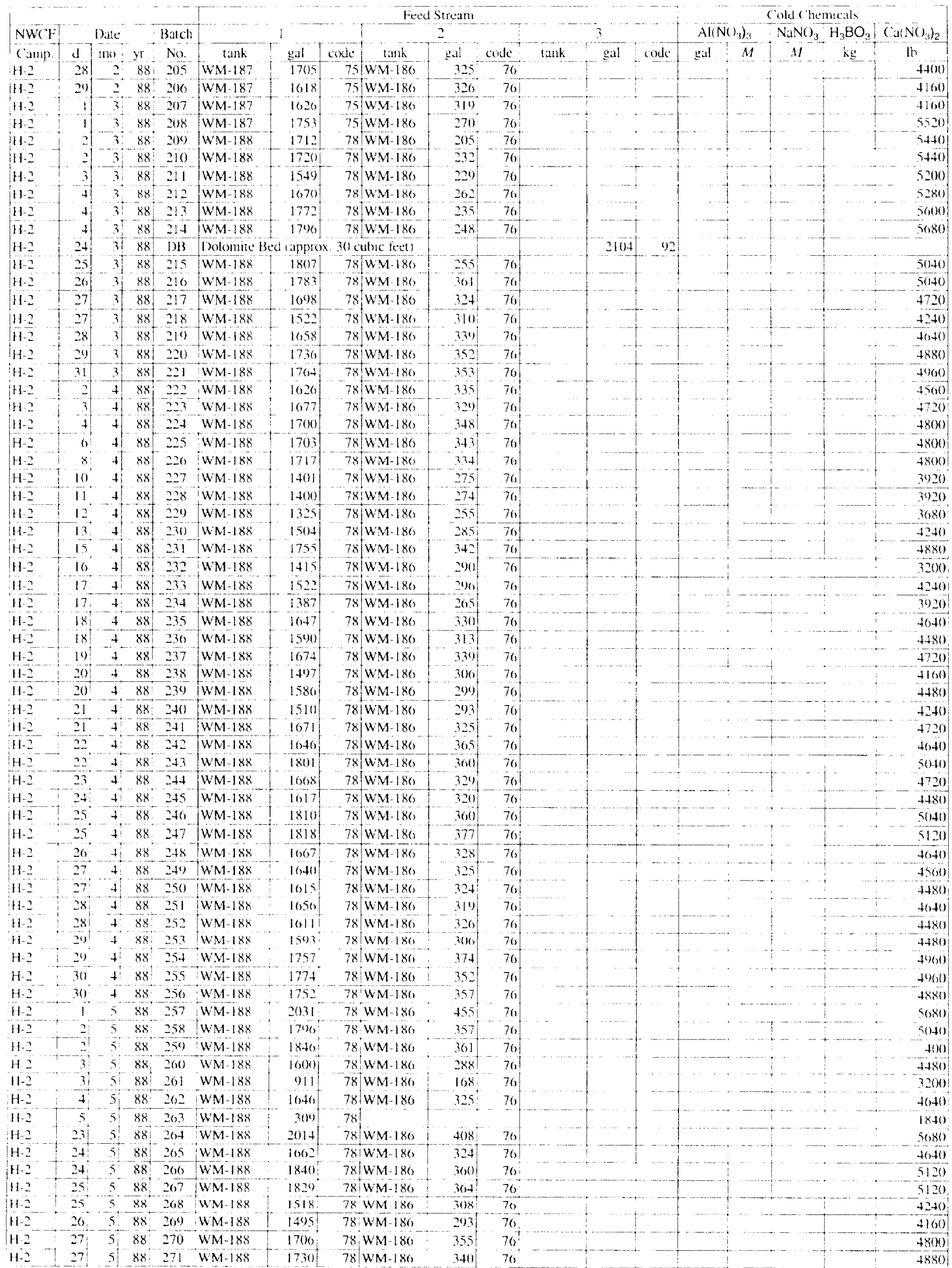


Table A5. Calciner Feed to Calcined Solids Storage Facility V. (continued)

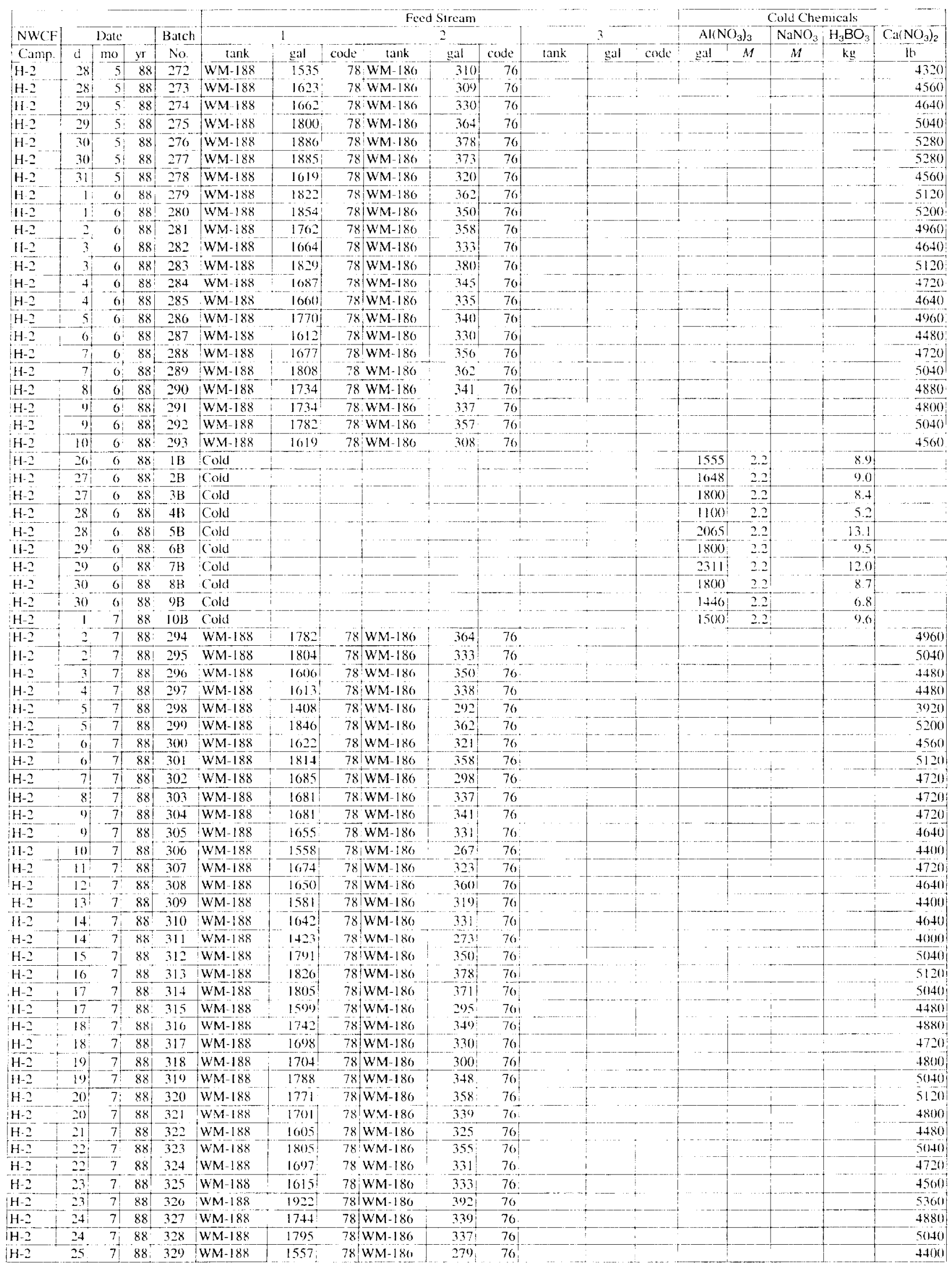


Table A5. Calciner Feed to Calcined Solids Storage Facility V. (continued)

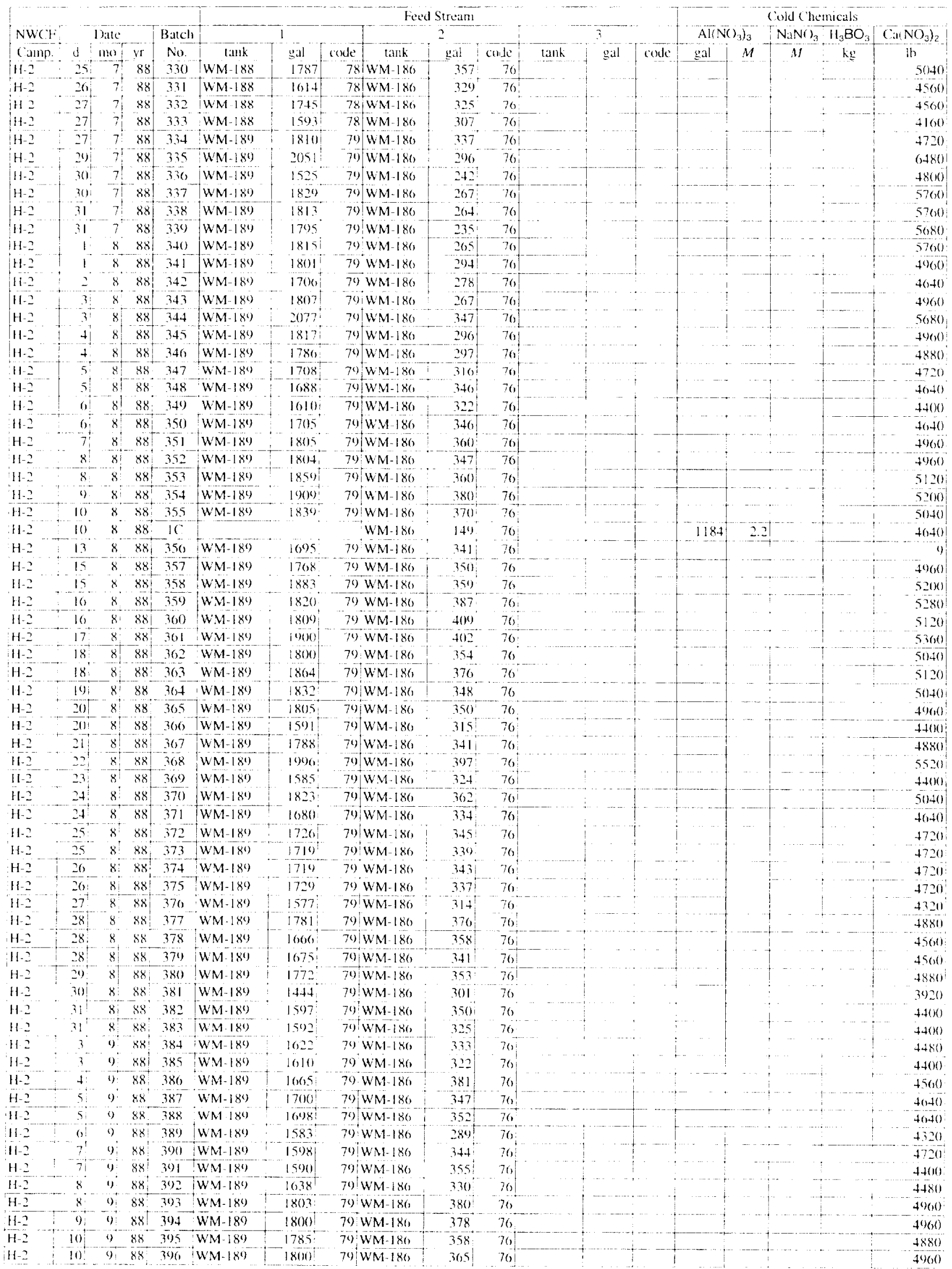


Table A5. Calciner Feed to Calcined Solids Storage Facility V. (continued)

\begin{tabular}{|c|c|c|c|c|c|c|c|c|c|c|c|c|c|c|c|c|c|c|}
\hline \multirow{3}{*}{$\frac{N W C F}{\text { Camp }}$} & \multirow{2}{*}{\multicolumn{3}{|c|}{ Date }} & \multirow{3}{*}{$\begin{array}{c}\text { Batch } \\
\text { No. }\end{array}$} & \multirow{2}{*}{\multicolumn{9}{|c|}{ Fend Strean }} & & & Cold Che & nicals & \\
\hline & & & & & & & & & & & & & & AlGNC & & $\mathrm{NaNO}_{3}$ & $\mathrm{H}_{3} \mathrm{BO}_{3}$ & $\mathrm{Ca}\left(\mathrm{NO}_{3}\right)_{2}$ \\
\hline & $d$ & mo & $\mathrm{yr}$ & & tank & gal & cude & tank & gal & code & $\operatorname{tank}$ & gal & code & gal & $M$ & $M$ & $\mathrm{~kg}$ & lb \\
\hline $\mathrm{H}-2$ & 11 & 9 & 88 & 397 & WM-189 & 1558 & 79 & WM- 180 & 312 & 76 & & & & & & & & 4240 \\
\hline $\mathrm{H}-2$ & 11 & 9) & 88 & 398 & $W M-189$ & 1778 & 79 & WM-180 & 358 & $76:$ & & & & & & & & 4880 \\
\hline $\mathrm{H}-2$ & 12 & 9 & 88 & 300 & WM-180 & 1618 & 79) & WM-180 & 316 & 76 & & & & & & & & 4480 \\
\hline $\mathrm{H}-2$ & 12 & 9 & 88 & 400 & WM-189 & 1694 & 79 & WM-186 & 345 & 76 & & & & & & & & 4640 \\
\hline 112 & 13 & 9 & 88 & 401 & WM-189 & 1798 & 79 & WM-180 & 308 & 70. & & & & & & & & 4900 \\
\hline $\mathrm{H}-2$ & 13 & 9 & 88 & 402 & $W M-189$ & 1800 & 79 & WM-180 & 361 & 76 & & & & & & & & 4960 \\
\hline $\mathrm{H}-2$ & 14 & 9 & 88 & 403 & WM-189 & 1954 & 79 & WM-180 & $40 !$ & 76 & & & & & & & & 5360 \\
\hline 1112 & 14 & 9 & 88 & 404 & WM 189 & 1919 & $79 \%$ & WM 186 & 394 & $76 !$ & & & & & & & & 5280 \\
\hline $\mathrm{H}-2$ & 15 & 9 & 83 & 405 & $W M-180$ & 1757 & 79 & WM-I 80 & $3+1$ & 76 & & & & & & & & 4800 \\
\hline $\mathrm{H}-2$ & 15 & 9 & 88 & 406 & WM-180 & 1911. & 79 & WM-186 & 401 & 70 & & & & & & & & 5200 \\
\hline $\mathrm{H}-2$ & 16 & 9 & 88 & 407 & WM-189 & 1809 & 79 & WM-186 & 410 & 76 & & & & & & & & 5200 \\
\hline $11-2$ & 16 & 9) & 88 & 408 & WM-189 & 1645 & 79 & WM-186 & 240 & 76 & & & & & & & & 4480 \\
\hline $\mathrm{H}-2$ & 17 & 9 & 88 & 409 & WN-189 & 18011 & 79) & WM-180 & 3.51 & 76 & & & & & & & & 4240 \\
\hline $\mathrm{H}-2$ & 18 & 9 & 88 & 410 & WM-189 & 2017 & 79 & WM-186 & 343 & 70 & & & & & & & & 4720 \\
\hline $\mathrm{H}-2$ & 18 & 9 & 88 & 411 & WM-189 & 1771 & 79 & WM- 180 & 363 & 76 & & & & & & & & 4880 \\
\hline $\mathrm{H}-2$ & $19 !$ & 9 & 88 & 412 & WM-189 & 1930 & 79 & WM-186 & 319 & 70 & & & & & & & & 5280 \\
\hline $\mathrm{H}-2$ & 19 & 9 & 88 & 413 & WM- 189 & 1808 & 79) & WM- 186 & 308 & $76 !$ & & & & & & & & 4900 \\
\hline$H 2$ & 20 & 9 & 88 & 414 & WM-189 & 1980 & 79 & $W M-180$ & 381 & 76 & & & & & & & & 5200 \\
\hline $\mathrm{H}-2$ & 20 & 9 & 88 & 415 & WM-189 & 1810 & 79 & WM-186 & 367 & 76 & & & & & & & & 4960 \\
\hline$H=2$ & $2 !$ & 9 & 88 & 416 & WM-189 & $1512 !$ & 79 & $W M-186$ & 304 & 76 & & & & & & & & 4160 \\
\hline $\mathrm{H}-\mathrm{Z}$ & 21 & 9) & 881 & 417 & WM-189 & 2000 & 79 & WM-186 & 389 & 76 & & & & & & & & 5440 \\
\hline $\mathrm{H}-2$ & 22 & 9 & 88 & 418 & WM-189 & 1998 & 79 & WM-186 & 408 & 76 & & & & & & & & 5440 \\
\hline $\mathrm{H}-2$ & 22 & 9 & 881 & +19 & WM-189 & 2004 & 79 & WM-186 & 35.5 & 70 & & & & & & & & 5520 \\
\hline $\mathrm{H}-2$ & 23 & 9 & $88 !$ & 420 & $W M-189$ & 1952 & 79 & WM-180 & 394 & 76 & & & & & & & & 5360 \\
\hline $\mathrm{H}-2$ & 23 & 91 & 88 & 421 & WM-181 & 20015 & 79 & WM-180 & 307 & 76 & & & & & & & & 5520 \\
\hline $\mathrm{H}_{2}$ & 24 & 9) & 88 & 422 & WM- 189 & 1620 & $79 !$ & WM- 180 & 320 & 70 & & & & & & & & 4560 . \\
\hline $\mathrm{H}-2$ & 24 & 9 & $88 !$ & 423 & WM-189 & 1526 & 791 & $W M-186$ & 254 & 76 & & & & & & & & 4240 \\
\hline $\mathrm{H}-2$ & 25 & 9 & $88 !$ & 424 & WM-189 & 1574 & 79 & $w M-180$ & 315 & 70 & & & & & & & & 4400 \\
\hline $\mathrm{H}-2$ & 25 & 9 & 88 & 425 & WM-189 & $1001:$ & 70 & $W M-180$ & .340 & 76 & & & & & & & & 5360 \\
\hline$H-2$ & 26 & 9 & 88 & 420 & WM-189 & 1.585 & $70)$ & WM-180 & 320 & 76 & & & & & & & & 4480 \\
\hline$H .2$ & $26 !$ & 9 & 88 & +27 & $W M-189$ & 1574 & 79 & $W M-186$ & 262 & 76 & & & & & & & & 4800 \\
\hline $\mathrm{H}-2$ & $27 !$ & 0 & 88 & 428 & WM-189 & 1609 & 79 & WM-180 & 3281 & 76 & & & & & & & & 4480 \\
\hline $\mathrm{H}-2$ & 37 & y & 88 & 429 & WM-189 & 2001 & 70 & WM- 180 & $36+1$ & 76 & & & & & & & & 5600 \\
\hline$H-2$ & $28 !$ & 9 & 88 & 430 & WM-189 & 1970 & 79 & $W M-180$ & 336 & 76 & & & & & & & & 5520 \\
\hline $\mathrm{H}-\mathrm{Z}$ & 20) & 9 & 88 & 431 & WM-1 89 & 1097 & 79 & WM- 180 & 358 & 76 & & & & & & & & 5600 \\
\hline $\mathrm{H}-2$ & $29 !$ & 9 & 88 & 432 & WM-189 & 1784 & 79 & WM- 180 & 300 & 70 & & & & & & & & 4960 \\
\hline $\mathrm{H}-2$ & 30 & 9 & 88 & 433 & WM-189 & 2013 & 79 & $W M-186$ & 354 & 76 & & & & & & & & 5600 \\
\hline $\mathrm{H}-2$ & 1 & 10 & 88 & 4.34 & WM-187 & 1855 & 751 & WM-180 & $374 !$ & 76 & & & & & & & & 4720 \\
\hline $\mathrm{H}=2$ & 1 & 10 & 88 & 435 & $W M-187$ & 1933 & 75 & WM-186 & 379 & 76 & & & & & & & & 4880 \\
\hline $\mathrm{H}-2$ & 2 & 10 & 88 & 436 & WM-187 & 2061 & 75 & WM-180 & 415 & 76 & & & & & & & & 5200 \\
\hline $\mathrm{H}-2$ & 2 & 10 & 88 & 437 & WM-187 & 1140 & $75 \mid$ & WM-186 & 271 & 76 & & & & & & & & 2320 \\
\hline $11-2$ & 3 & 10 & 88 & 438 & WM-189 & 1958 & 79 & WM-180 & 412 & 76 & & & & & & & & 5520 \\
\hline $\mathrm{H}-2$ & 3 & 10 & 88 & 435 & WM-189 & $198 !$ & 791 & WM-186 & 397 & 70 & & & & & & & & 5520 \\
\hline$H-2$ & 4 & 10 & 88 & 440 & WM-189 & 1900 & 79 & WM- 180 & 391 & 76 & & & & & & & & 5520 \\
\hline$H 2$ & 5 & 10 & 88 & 411 & WM I89 & 1801 & 79 & WM 180 & 376 & 76 & & & & & & & & 5040 \\
\hline $\mathrm{H}-2$ & 6 & 10 & 88 & 442 & WM-180 & 1973 & $79 \mathrm{j}$ & WM-186 & 3.34 & 76 & & & & & & & & 5520 \\
\hline $\mathrm{H}-\mathrm{Z}$ & 27 & 11 & 88 & $\mathrm{DB}$ & Dolomite & d capprox & $\times .110 c$ & cubic fect! & & & & $7715 !$ & 92 & & & & & \\
\hline $\mathrm{H}-2$ & 27 & II & 88 & 16 & Cold & & & & & & & & & $225)^{\circ}$ & 2.2 & & 10.6 & \\
\hline $\mathrm{H}=2$ & 28 & 11 & 88 & $D B$ & Dolomite & d capprox & र. $15 \mathrm{cu}$ & dbic f(et) & & & & 1052 & 92 & & & & & \\
\hline $\mathrm{H}-2$ & 28 & 11 & 88 & $\mathrm{DB}$ & Dolomite: & $d$ capprox & $15 \mathrm{cu}$ & sbic fets) & & & & 10521 & 92 & & & & & \\
\hline $\mathrm{H}-2$ & 28 & 11 & 88 & $\mathrm{DB}$ & Dolomite & dapprox & $15 \mathrm{cu}$ & bic feet) & & & & 1052 & 92 & & & & & \\
\hline H-2 & 20 & 11 & 88 & $2 C$ & Cold & & & & & & & & & 826 & 2.2 & & 4.2 & \\
\hline$H-2$ & 26 & 11 & 88 & $3 C$ & Cold & & & & & & & & & 1500 & 2.2 & & 7.0 & \\
\hline $\mathrm{H}-2$ & 30 & 11 & 88 & $4 C$ & Cold & & & & & & & & & 1330 & 2.2 & & 6.2 & \\
\hline $11-2$ & $2 !$ & $12 !$ & $88^{\circ}$ & $5 C$ & Cold & & & & & & & & & $1.5000_{0}$ & 2.2 & & 7.0 & \\
\hline $\mathrm{H}-2$ & 3 & 12 & 88 & $6 \mathrm{C}$ & cold & & & & & & & & & 2000 & 2.2 & & t) 4 & \\
\hline $\mathrm{H}-2$ & 8 & 12 & 88 & $7 \mathrm{C}$ & Cold & & & & & & & & & 1000 & 2.2 & & 60 & \\
\hline $\mathrm{H}=\mathrm{Z}$ & 8 & 12 & 88 & $8 \mathrm{C}$ & Cold & & & & & & & & & 1040 & 2.2 & & 76 & \\
\hline $\mathrm{H}-2$ & 9 & $12 !$ & 88 & 90 & cold & 1 & & & & & & & & 1154 & 2.2 & & 5.0 & \\
\hline $\mathrm{H}-3$ & 28 & 5 & 89 & $\mathrm{DB}$ & Dolomite & dapprox & $35 \mathrm{cu}$ & bic feet! & & & & 2455 & 92 & & & & & \\
\hline $\mathrm{H}-3$ & 29 & $5 !$ & 89 & DB & Dolomite $\mathrm{P}$ & $d$ approx & $.35 \mathrm{cul}$ & Jbic feet! & & & & 2455 & 92. & & & & & \\
\hline $11-3$ & 29 & 5 & $89 !$ & DB & Dolomile B & d approx & $35 \mathrm{cu}$ & bic feet & & 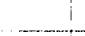 & & 2455 & 92 & & & & & \\
\hline $\mathrm{H}-3$ & $|9|$ & 6 & 89 & $D B$ & Dolomite $\mathrm{B}$ & d capprox & $.15 \mathrm{cul}$ & bic feet! & & & & 1052 & 92 & & 1 & & & \\
\hline $\mathrm{H}-3$ & 19 & 0 & $89 !$ & DB & IDolomite & d approx & $.15 \mathrm{cul}$ & bic feet) & & & & 1052 & 2 & & & & & \\
\hline $\mathrm{H}-3$ & $19 ?$ & 6 & 89 & $\overline{\mathrm{DB}}$ & Dolomite & d approx & $15 \mathrm{cul}$ & bic feet) & & & & 1052 & $92 !$ & & & & & \\
\hline $\mathrm{H}+3$ & 18 & 6 & 89 & $1 C$ & Cold & & & & & & & & & 2640 & 2.2 & & 124 & \\
\hline $\mathrm{H}-3$ & 18 & 6 & 89 & $2 \mathrm{C}$ & Cold & & & & & & & & & 2416 & 2.2 & & 11.3 & \\
\hline$H-.3$ & 21 & 6 & 89 & 30 & Cold & & & & & & & & & 1992 & $2.2 !$ & & 11.3 & \\
\hline
\end{tabular}


Table A5. Calciner Feed to Calcined Solids Storage Facility V. (continued)

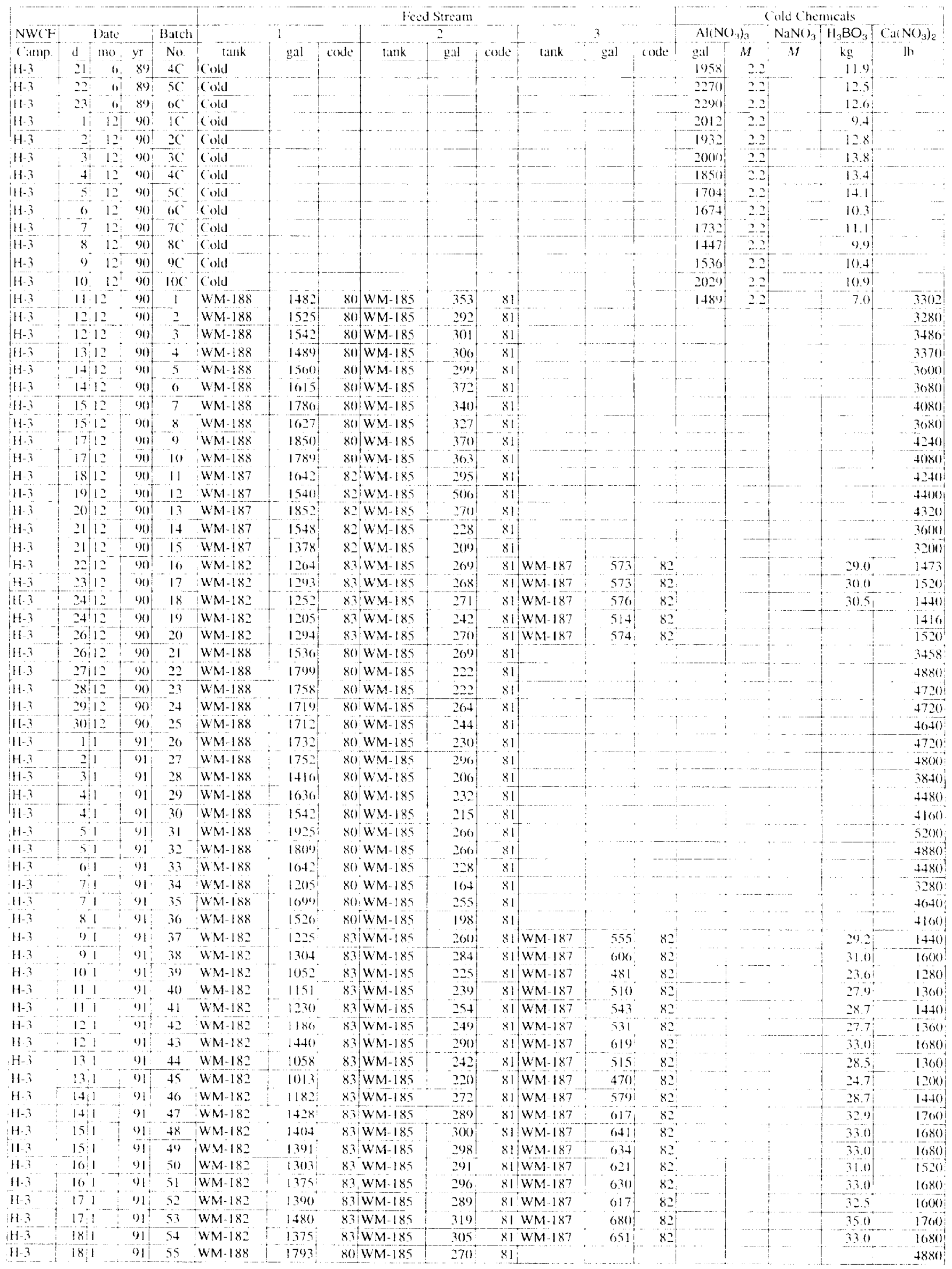


Table A5. Calciner Feed to Calcined Solids Storage Facility V. (continued)

\begin{tabular}{|c|c|c|c|c|c|c|c|c|c|c|c|c|c|c|c|c|c|c|}
\hline \multirow{3}{*}{$\begin{array}{l}\text { NWCF: } \\
\text { Camp. }\end{array}$} & & \multicolumn{9}{|c|}{ liced Stream } & \multicolumn{5}{|c|}{ Cold Cherrucals } \\
\hline & & Date & & Batch & & 1 & & & 2 & & & 3 & & $\mathrm{Al}(\mathrm{NO}$ & $\left.3_{3}\right)_{3}$ & $\mathrm{NaNO}_{3}$ & $\mathrm{H}_{3} \mathrm{BO}_{3}$ & $\mathrm{Ca}\left(\mathrm{NO}_{3}\right)_{2}$ \\
\hline & d & mo & $\mathrm{yr}$ & No. & $\operatorname{tank}$ & gal & code & lank & gal & $\operatorname{code}$ & tank & gal & code & gal & $M$ & $M$ & $\mathrm{~kg}$ & In \\
\hline $\mathrm{H}-3$ & 191 & & 911 & 56 & WM-188 & 1807 & 80 & WM1-185 & 313 & 81 & & & & & & & & 4960 \\
\hline $\mathrm{H}-3$ & 20) 1 & & 91 & 57 & WM-1 88 & 1728 & 80 & WM-185 & 302 & 81 & & & & & & & & 4720 \\
\hline $11-3$ & 201 & & 91 & 58 & WM-182 & $1+51$ & 83 & $W M-185$ & 274 & 81 & WM-187 & 731 & 82 & & & & 34.0 & 1760 \\
\hline $\mathrm{H}-3$ & 211 & & 91 & 59 & WM-182 & 1265 & 83 & $W M-185$ & 2013 & 81 & WM- 187 & 600 & 82 & & & & 29.3 & $1+40$ \\
\hline $\mathrm{H}-3$ & 21 & & 91 & 61) & WM-182 & 1238 & 83 & WM- 185 & 2010 & 81 & WM-187 & 627 & 82 & & & & 29.5 & 1520 \\
\hline $11-3$ & 221 & & 91 & 61 & WM-182 & 1063 & 83 & WM-185 & 2337 & 811 & WM-18? & 6909 & 82 & & & & 28.0 & 1760 \\
\hline $\mathrm{H}-3$ & 221 & & 91 & 62 & WM-182 & 986 & 83 & WM-185 & 222 & 81 & WM-187 & 660 & 82 & & & & 26.5 & 1680 \\
\hline $\mathrm{H}-3$ & 231 & & $9 i$ & 63 & WM-182 & 1078 & 83 & $W M-185$ & 231 & 81 & WM- 187 & (6) 3 & 82 & & & & 28.5 & 1760 \\
\hline $\mathrm{H}-3$ & 241 & & 91 & 64 & WM-182 & 1128 & 8.3 & WM- 185 & 242 & 81 & WM-187 & 726 & 82 & & & & 29.6 & 1840 \\
\hline $\mathrm{H}-3$ & $2 4 \longdiv { 1 }$ & & 91 & 65 & $W M-182$ & 1081 & 83 & WM-185 & 233 & 81 & WM-187 & 690 & 82 & & & & 28.5 & 1760 \\
\hline $\mathrm{H}-3$ & 251 & & 91 & 60 & WM-182 & 1079 & 83 & WM- 185 & 230 & 81 & WM- 187 & 690 & 82 & & & & 28.37 & 1760 \\
\hline $\mathrm{H}-3$ & 251 & & 1) & 67 & WM-182 & 148 & 83 & WM- 185 & 33 & 81 & WM- 187 & 99 & 82 & & & & 40 & 240 \\
\hline $\mathrm{H}-3$ & 10 & 3 & 91 & DB & Dolomite $B$ & d capprox. & 1000 & cubic fect) & & & & 7014 & 92 & & & & & \\
\hline $\mathrm{H}-3$ & 11 & 3 & (1) & $\overline{\mathrm{DB}}$ & Dolomite $\mathrm{B}$ & d capprox & $13 \mathrm{cu}$ & ubic feets & & & & 885 & 92 & & & & & \\
\hline$H-3$ & 11 & 3 & 91 & $\mathrm{DB}$ & Dolomite $B$ & d (approx. & $25 \mathrm{cu}$ & ubic & & & & 1770 & i) 2 & & & & & \\
\hline $\mathrm{H}-3$ & 11 & 3 & 91 & IIC & Cold & & & & & & & & & 1804 & 2.2 & & 8.4 & \\
\hline $\mathrm{H}-3$ & 12 & 3 & 91 & $\mathrm{DB}$ & Dolomite $B$ & $\mathrm{~d}$ (approx. & $18 \mathrm{cu}$ & ubic fect & & & & 1239 & 92 & & & & & \\
\hline $11-3$ & 12 & 3 & 91 & $\mathrm{D} B$ & Dolomite B & d fapprox. & 8 cub & bic teet & & & & 531 & 22 & & & & & \\
\hline $\mathrm{H}-3$ & 12 & 3 & 91 & $\mathrm{DB}$ & Dolomite $B$ & d (approx. & $.23 \mathrm{cu}$ & ubic feell & & & & 1593 & 92 & & & & & \\
\hline $\mathrm{H}-3$ & 12 & 3 & 91 & 125 & Cold & & & & & - & & & & 1956 & 2.2 & & 9.2 & \\
\hline $1 \mathrm{H}-3$ & 13 & 3 & 91 & $13 \mathrm{C}$ & Cold & $\vdots$ & & & & & & & & 1712 & $2.15 ?$ & & 110 & \\
\hline $\mathrm{H}-3$ & 14 & 3 & 91 & $\mathrm{DB}$ & Dolomite $\mathrm{B}$ & d capprox. & $15 \mathrm{cu}$ & uhic tedl & & & & 10621 & 92 & & & & & \\
\hline $1+3$ & 14 & 3 & 91 & $14 \mathrm{C}$ & Cold & & & & & & & 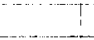 & & 1512 & 2.2 & & 120 & \\
\hline $\mathrm{H}-3$ & 14 & 3. & 91 & $15 C$ & Cold & & & & & & & & & 1523 & 2.2 & & 9.3 & \\
\hline $\mathrm{H}-3$ & 16 & 31 & 91 & 160 & Cold & & & & & $\cdots$ & & & & 1511 & 2.12 & & 11.4 & \\
\hline $\mathrm{H}-3$ & 161 & 3 & 91 & $17 \mathrm{C}$ & Cold & & & & & 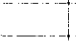 & & & & 1025 & 2.2 & & 0.3 & \\
\hline $\mathrm{H}-3$ & 30 & 3 & 91 & $18 \mathrm{C}$ & Cold & & & & & & & & & 1823 & 2.2 & & 110 & \\
\hline$\sqrt{1-3}$ & 2 & 4 & 91 & 190 & Cold & & & & & & & & & 1454 & 2.2 & & 7.7 & \\
\hline $\mathrm{H}-3$ & 3 & 4 & $91 !$ & 68 & WM-188 & 2034 & 80 & WM-185 & 277 & 811 & & & & & & & & 5520 \\
\hline $\mathrm{H}-3$ & 4 & + & $9 i^{1}$ & 69 & $\mathrm{M}-188^{\circ}$ & 1970 & 80 & WM-185 & 327 & 81 & & & & & & & & 5360 \\
\hline $\mathrm{H}-3$ & 6 & 4 & 91 & 70 & $W M-188$ & 1596 & 80 & WM-I85 & 249 & 81 & & & & & & & & 4352 \\
\hline $\mathrm{H}-\overline{3}$ & 7 & 4 & $9)$ & 71 & WM- 188 & 1767 & $80 !$ & WM-185 & 302 & 81 & & & & & & & & 4800 \\
\hline $\mathrm{H}-3$ & 8 & $4 \dagger$ & (9) & 72 & WM-188 & 1793 & $80 \mid$ & WM-185 & 318 & $8 i$ & & & & & & & & 4880 \\
\hline $11-3$ & 8 & 4 & 91 & 73 & WM-188 & $1 \overline{757}$ & $80 \uparrow$ & WM-185 & 269 & 81 & & & & & & & & 4800 \\
\hline $\mathrm{H}-3$ & 9 & 4 & 211 & 74 & WM 188 & 1433 & 80 & WM 185 & 237 & 81 & & & & & & & & 4000 \\
\hline $\mathrm{H}-3$ & 10 & 4 & $9 !$ & 75 & WM-182 & 754 & 83. & WM-185 & 162 & 81 & WM-187 & 486 & 82 & & & & 10.8 & 1212 \\
\hline $\mathrm{H}-3$ & 10 & 4 & 91 & 76 & $1-182$ & 763 & 83 & WM-185 & 164 & 81 & WM- 187 & 490 & 82 & & & & 10.8 & 1280 \\
\hline $\mathrm{H}-3$ & $11 i$ & 4 & 911 & 77 & 4-182 & 1012 & $83 i$ & WN-185 & 217 & 81 & WM- 187 & 650 & 82 & & & & 26.6 & 1000 \\
\hline $\mathrm{H}-3$ & 111 & 4 & 91 & 78 & WM-182 & 1378 & 83 & WM-185 & 295 & 81 & WM- 187 & $880^{\circ}$ & 82 & & & & 36.2 & 2240 \\
\hline $11-3$ & 121 & 4 & 91 & 79 & WM-182 & 987 & 83 & WM-185 & $211^{\circ}$ & 81 & WM-I 87 & $633^{\circ}$ & 821 & & & & 259 & 1600 \\
\hline $\mathrm{H}-3$ & $13 !$ & 4 & 91 & 80 & WM-182 & 1270 & 83 & $W M-18=$ & 219 & 81 & WM-187 & 6.50 & 82 & & & & $30.3]^{1}$ & 1680 \\
\hline $\mathrm{H}-3$ & 13 & 4 & $9 !$ & 81 & WM-182 & 1207 & 83 & WM- 185 & 250 & 81 & WM- 187 & 7608 & 82 & & & & 31.5 & 1920 \\
\hline $\mathrm{H}-3$ & 14 & 4 & 91 & 82 & WM-182 & 1096 & 83 & WM-185 & 230 & 81 & WM-187 & (6)1 & 82 & & & & 28.5 & 1760 \\
\hline $\mathrm{H}-3$ & 14 & 4 & $9 !$ & $\mathrm{DB}$ & Dolomite $\mathrm{B}$ & d capprox. & $18 \mathrm{cu}$ & ubic fect) & & & & 1278 & 92 & & & & & \\
\hline $\mathrm{H}-3$ & 15 & + & 91 & 83 & WM-182 & $1001 !$ & 835 & WM-185 & 215 & 81 & WM-187 & 644 & 827 & & & & 26.4 & 1600 \\
\hline $\mathrm{H}-3$ & 15 & 4 & 9 & $\mathrm{DB}$ & Dolomite $\mathrm{F}$ & (approx. & $26 \mathrm{cu}$ & ubic fiect) & & & & 1789 & 92 & & & & & \\
\hline $\mathrm{H}-3$ & 16 & 4 & 91 & 84 & & 59) & $83 \pi$ & $W M-185$ & 162 & 81 & WM-187 & 6065 & 82 & 649 & 2.2 & & 17.6 & 1900 \\
\hline$H \cdot 3$ & 16 & + & 91 & 85 & 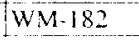 & 652 & $83 i$ & $W M-185$ & $2(09)$ & 81 & WM- 187 & 836 & 82 & 623 & $2.2 \uparrow$ & & 18.5 & 2000 \\
\hline $\mathrm{H}-3$ & 17 & 4 & 91 & 80 & $4-182$ & 022 & 835 & $\mathrm{WI}$ & 196 & 81 & WM- 187 & 799 & 82 & 651 & 2.2 & & 21.0 & 1920 \\
\hline $\mathrm{H}-3$ & 18 & 4 & 91 & 87 & 3. & 638 & $83 \mid$ & $W M-185$ & 204 & 81 & W & 813 & 82 & 710 & 2.21 & & 24.0 & 2000 \\
\hline $11-3$ & 10) & 4 & 91 & 88 & ii & 6 & 831 & WM & 189 & 81 & W & 756 & 82 & 641 & 2.2 & & 22.0 & 1840 \\
\hline $\mathrm{H}-3$ & 19 & 4 & 91 & 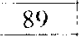 & u & 6 & 831 & & 218 & 81 & & 870 & 82 & 665 & $2.2 !$ & & 23.0 & 2097 \\
\hline $\mathrm{H}-3$ & 20 & 4 & 91 & 90 & $1-182$ & 610 & 831 & WM-185 & 190 & 81 & WM-187 & 797 & 82 & 730 & 2.2 & & 34.6 & 1923 \\
\hline $\mathrm{H}-3$ & 21 & 4 & 91 & 91 & $1-182$ & 631 & 83 & WM- 185 & 204 & 81 & WM- 187 & 816 & 82 & $66^{0}$ & 2.2 & & 32.3 & $20(0)$ \\
\hline $\mathrm{H}-3$ & 21 & 4 & 91 & 92 & 11 & $639^{\circ}$ & 83 & WM- 185 & $205^{\circ}$ & 81 & WM-187 & 822 & 82 & 630 & 2.2 & & 334 & 2000 \\
\hline $\mathrm{H}-3$ & 22 & 4 & 91 & 3 & in & 649 & 831 & WI & 201 & 81 & $W$ & $836^{\circ}$ & $82 !$ & 647 & 2.2 & & 34.5 & 20000 \\
\hline $\mathrm{H}-3$ & 23 & 4 & 91 & 94 & $1-1$ & $616]$ & 831 & WM & 197 & 81 & WM-187 & 786 & $82 !$ & 602 & 22 & & 332 & 1920 \\
\hline $\mathrm{H}-3$ & 24 & 4 & 91 & 95 & $\mathrm{M}-182$ & 611 & 831 & WM-185 & 190 & 81 & WM-187 & 782 & 82 & $644^{\dagger}$ & 2.2 & & 334 & 1920 \\
\hline $\mathrm{H}-3$ & 24 & 4 & 91 & 96 & $4-182$ & 608 & $83 ! 1$ & WM-185 & 103 & 81 & WM-187 & 7701 & 82 & 593 & 22 & & 32.0 & 1920 \\
\hline $\mathrm{H}-3$ & 25 & 4 & 91 & 97 & WM-182 & $\left.735\right|^{\circ}$ & $83 i 1$ & WM-1 85 & $207 !$ & 81 & WM-187 & 829 & 82 & 533 & 22 & & 33.6 & 2008 \\
\hline H.3 & 26 & 4 & 91 & 98 & $W M-182$ & 741 & 831 & WM-185 & 204 & 81 & WM-187 & $818^{+}$ & 82 & 574 & 2.2 & & 33.2 & 2000 \\
\hline $\mathrm{H}-3$ & 27 & 4 & 91 & 99 & WM-182 & 735 & $83 \sqrt{5}$ & WM-185 & 206 & 811 & WM-187 & 822 & 82 & 545 & 22 & & 34.0 & 2000 \\
\hline $\mathrm{H}-3$ & 27 & 4 & 91 & 100 & WM-182 & $690^{\circ}$ & 8315 & WM-185 & 188 & 811 & WM-187 & 754 & 82 & 530 & $2.2 !$ & & 28.3 & 1840 \\
\hline $\mathrm{H}-3$ & 281 & 4 & 91 & 101 & WM-182 & (6) 1 & 83.4 & WM-185 & {$[03]$} & $81 !$ & $16 M-187$ & $770^{\circ}$ & 82 & 274 & $2.2 !$ & & 24.8 & 1840 \\
\hline $\mathrm{H}-3$ & 29 & 4 & 91 & 102 & WM-182 & 083 & 837 & WM-185 & 218 & 81 & $W M-187$ & 874 & $82 !$ & 292 & 2.2 & & 330 & 2100 \\
\hline $\mathrm{H}-3$ & 30 & $4 !$ & 91 & 103 & 4-182. & 1043 & 834 & WM- 185 & 207 & 81 & WM-187 & 830 & 82 & 231 & 22 & & 32.4 & 2080 \\
\hline $\mathrm{H}-3$ & 11 & 5 & 91 ! & (1) & 1-182 & 1) 63 & $83 \pi$ & & 11)4 & $81 !$ & & 777 & 82 & 248 & 2.2 & & 30.1 & 1920 \\
\hline $\mathrm{H}-3$ & $2 !$ & 5 & 91 & 105 & WM-182 & $\overrightarrow{993}$ & $83 \mathrm{~V}$ & WM.185 & 2015 & $81^{\circ}$ & $W M-187$ & 819 & 82 & 275 & 22 & & 33.3 & 2000 \\
\hline
\end{tabular}


Table A5. Calciner Feed to Calcined Solids Storage Facility V. (continued)

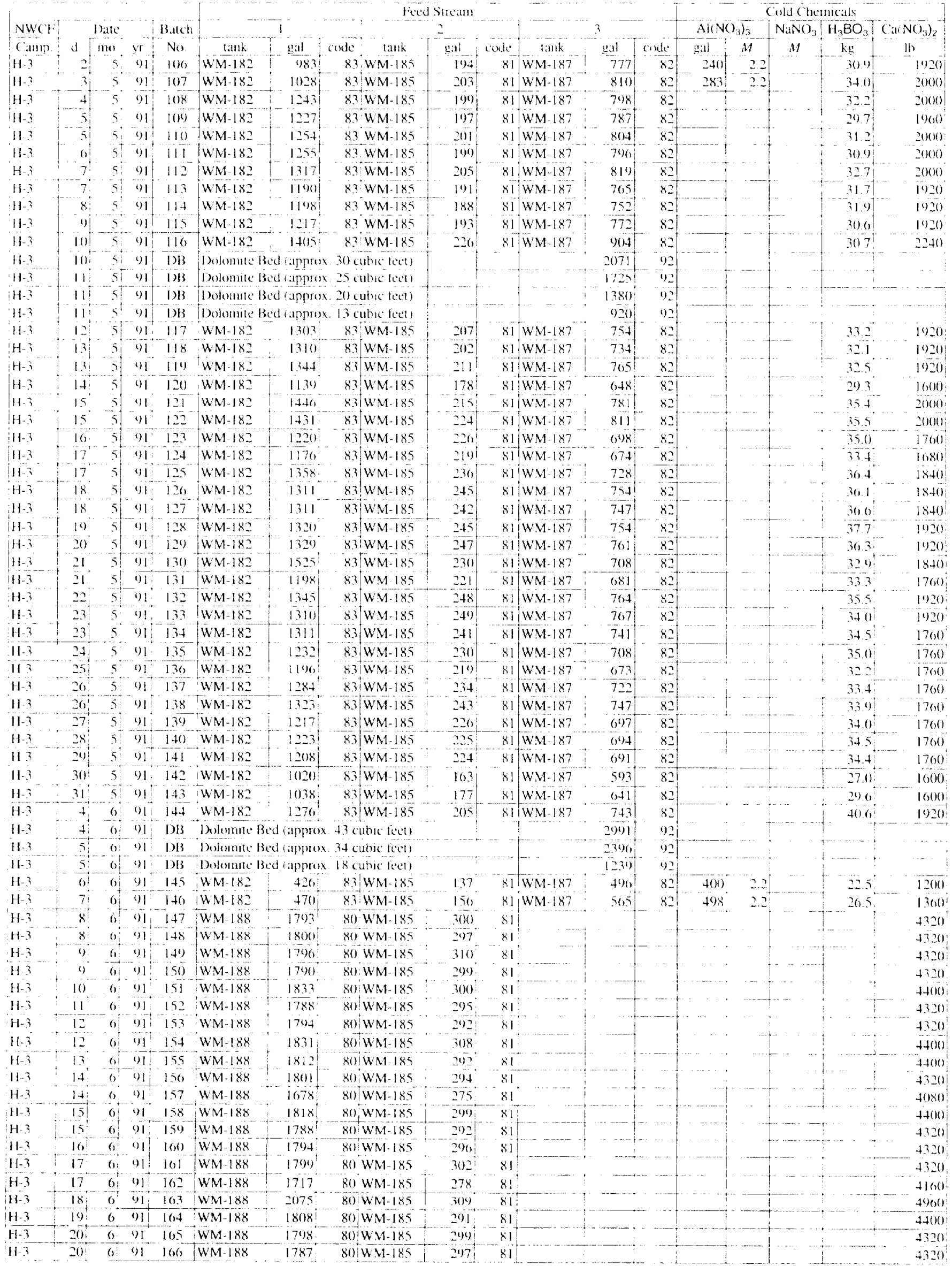


Table A5. Calciner Feed to Calcined Sulids Storage Facility V. (continued)

\begin{tabular}{|c|c|c|c|c|c|c|c|c|c|c|c|c|c|c|c|c|c|c|}
\hline \multicolumn{5}{|c|}{ 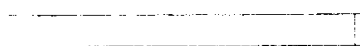 } & \multicolumn{9}{|c|}{ Feed sirean } & \multicolumn{5}{|c|}{ Cold Chemicals } \\
\hline \multirow{2}{*}{$\begin{array}{l}\text { NWCF } \\
\text { Camp. }\end{array}$} & & Date & & Batch & & & & & 2 & & & 3 & & AllNO & & $\mathrm{NaNO}_{3}$ & $\mathrm{H}_{3} \mathrm{BO}_{3}$ & $\mathrm{Ca}\left(\mathrm{NO}_{3}\right)_{2}$ \\
\hline & d & mo & $\mathrm{yr}$ & No. & tank & gal & code & Lunk & gal & code & tank & gal & code & gal & $\bar{M}$ & $M$ & $\mathrm{~kg}$ & th \\
\hline $\mathrm{H}-3$ & 21 & 6 & 91 & 167 & WM-188 & 1819 & 80 & WM-185 & 303 & 81 & & & & & & & & $4400^{\prime}$ \\
\hline $\mathrm{H}-3$ & 22 & 6 & 91 & 168 & VM-188 & 1829 & $80 \mid$ & WM- 185 & 307 & 81 & & & & & & & & $4400^{\circ}$ \\
\hline $\mathrm{H}-3$ & 22 & 6 & 91 & 109 & $\sqrt{M-188}$ & 1799 & 80 & WM- 185 & 296 & 81 & & & & & & & & 4320 \\
\hline $\mathrm{H}-3$ & 23 & 6 & 91 & 170 & VM-188 & 1784 & 80 & WM- 185 & 295 & 811 & & & & & & & & +420 \\
\hline$[11-3$ & 24 & 6 & 91 & 171 & $M-188$ & 1767 & 80 & WM-185 & 291 & 81 & & & & & & & & 4240 \\
\hline $\mathrm{H}-3$ & 25 & 6 & 91 & 172 & $V M-188$ & 1802 & 80 & WM-185 & 200 & 81 & & & & & & & & 4320 \\
\hline $\mathrm{H}-3$ & 25 & 6 & 91 & 173 & $V M-188$ & 1699 & $80 \uparrow$ & WM- 185 & 291 & $81 \dagger$ & & & & & & & & 4080 \\
\hline $\mathrm{H}-3$ & 26 & 6 & 91 & $17 \overline{74}$ & WM-188 & $1781^{\circ}$ & $80^{\dagger}$ & WM-185 & 296 & 81 & & & & & & & & 4240 \\
\hline $\mathrm{H}-3$ & 27 & 6 & 91 & 175 & $V M-188$ & 1799 & 80 & WM- 185 & 3017 & 81 & & & & & & & & 4320 \\
\hline H-3 & 27 & 6 & i)1 & 176 & MM- 188 & $1780^{\circ}$ & 80 & $W M-185$ & 208 & 81 & & & & & & & & 4240 \\
\hline H-3 & 28 & 6) & 91 & 177 & $M-188$ & 1798 & 80 & $W M-185$ & $2455^{-}$ & 81 & & & & & & & & 4320 \\
\hline $\mathrm{H}-3$ & 20 & 6 & 91 & 178 & M-188 & 1813 & 80 & WM- 185 & $302 !$ & $81 !$ & & & & & & & & 4320 \\
\hline $\mathrm{H}-3$ & $30^{\circ}$ & (6) & 91 & 179 & $W M-188$ & 1788 & 80 & WM-185 & 208 & 81 & & & & & & & & 4320 \\
\hline $\mathrm{H}-3$ & 30 & 6 & 91 . & 80 & WM-188 & 1920 & 80 & WM-185 & $320^{\circ}$ & 81 & & & & & & & & $4640^{\prime}$ \\
\hline $\mathrm{H}-3$ & 1 & 7 & 91 & 181 & M-188 & 1794 & 80 & WM- 185 & 3010 & 81 & & & & & & & & 4320 \\
\hline $1 \mathrm{H}-3$ & 2 & 7 & 91 & 182 & $M-188$ & 1804 & 80 & WM-185 & 209 & 81 & & & & & & & & 4320 \\
\hline $\mathrm{H}-3$ & 2 & 7 & 91 & 183 & $W M-182$ & 845 & 83 & WM-185 & $172 !$ & 81 & WM-187 & 658 & 82 & 219 & 2.2 & & 29.0 & 1600 \\
\hline $\mathrm{H}-3$ & 3 & 7 & 91 & 184 & WM- IS2 & $x+1$ & 83 & $W M-1 \times 5$ & 193 & 81 & WM-187 & $602 !$ & $82 !$ & 232 & 2.2 & & 30.0 & 1600 \\
\hline $\mathrm{H}-3$ & 4 & 7 & 91 & 185 & WM-182 & 84.4 & $83 i$ & WM- 185 & 173 & 81 & WM-187 & 6601 & 82 & 222 & 2.2 & & 31.4 & 1680 \\
\hline $\mathrm{H}-\mathrm{i}$ & 5 & 7 & 91 & 180 & WM-182 & 831 & 83 & WM-185 & 167 & 81 & WM-187 & 6319 & 82 & 232 & 2.2 & & 30.2 & $1000^{3}$ \\
\hline $\mathrm{H}-3$ & 5 & 7 & 91 & 187 & WM-182 & 831 & 83 & WM-185 & 168 & 81 & $W M-187$ & 640 & 82 & 440 & 2.2 & & 30.0 & $1600^{\circ}$ \\
\hline $11-3$ & 5 & 7 & $9 !$ & $\mathrm{DB}$ & Dolonite & $d$ approx & $x .21 \mathrm{cu}$ & ubic feell & & & & 1438 & $92 i$ & & & & & \\
\hline $11-3$ & 6 & 7 & 91 & 188 & WM-182 & 838 & 83 & WM- 185 & 171 & 81 & $W M-187$ & 053 & $82 i$ & 604 & 22 & & 380 & 2249 \\
\hline $\mathrm{H}-3$ & 0 & $7 \dagger$ & 91 & 8) & WM- & 856 & 83 & W & 174 & 81 & WM-187 & 064 & $82 !$ & 516 & 2.2 & & 33.0 & 1600 \\
\hline $\mathrm{H} \cdot 3$ & 71 & 7 & 91 & 90 & WM-1 & 501 & 83 & WM-I85 & 168 & 815 & WM- 187 & 641 & $82^{\circ}$ & 510 & $2 ?$ & & 280 & $\ln (0)$ \\
\hline $\mathrm{H}-3$ & 8 & 7 & 91 & 191 & WM-182 & 574 & 831 & WM-185 & 174 & 81 & $W M-187$ & 60.3 & 82 & 557 & 2.2 & & 28.1 & 1600 \\
\hline$H-3$ & 8 & 7 & 91 & 192 & WM-182 & 573 & 83 & WM- 185 & 108 & 81 & $W M-187$ & 640 & 82 & 494 & 22 & & 25.5 & 1520 \\
\hline $11-3$ & $9:$ & 71 & 91 & 193 & WM-182 & 560 & 83 & $\overline{W N}$ & 171 & 81 & $W M-187$ & 6.54 & 82 & 518 & 2.2 & & 26.6 & 1600 \\
\hline $\mathrm{H}-3$ & 9 & 7 & 91 & 194 & WM-182 & 698 & 831 & WM-185 & 225 & 81 & $W M-187$ & 861 & 82 & 640 & 2.2 & & 33.6 & $2080^{\circ}$ \\
\hline $\mathrm{H}-3$ & 10 & 7 & 01 & 195 & WM-182 & 678 & 831 & WM- 185 & 204 & 81 & WM- 187 & $781 !$ & 82 & 624 & 22 & & 330 & $19 ? 0$ \\
\hline $\mathrm{H}-3$ & 10 & 7 & 91 & 196 & WM-182 & 681 & 83 & WN & 201 & 81 & WM- 187 & $76^{\circ}$ & 82 & 607 & 22 & & 31.8 & 1840 \\
\hline $\mathrm{H}-3$ & 11 & 7 & 91 & 1 & $\mathrm{WM}$ & 682 & 83 & W & 202 & $81{ }^{\dagger}$ & WM-187 & 771 & 82 & 660 & $2.2 !$ & & 33.0 & 1840 \\
\hline $\mathrm{H}-3$ & 12 & 7 & 91 & 198 & WM 182 & 542 & 831 & WM- 185 & 102 & 81 & WM-187 & 617 & 82 & 472 & 2.2 & & 20.0 & 1080 \\
\hline $\mathrm{H}-3$ & 12 & 7 & $91^{\dagger}$ & 199 & WM-182 & $740{ }^{\dagger}$ & $83 \mid$ & WM-185 & 216 & 81 & WM-187 & 823 & 82 & 658 & 2.2 & & 342 & 20000 \\
\hline $\mathrm{H}-3$ & 13 & 7 & 91 & 200 & $W M 182$ & 743 & 831 & WM 185 & 209 & 81 & WM 187 & 800 & $82 !$ & 605 & 2.2 & & 34.7 & 2000 \\
\hline $\mathrm{H}-3$ & 14 & 7 & 91 & 201 & $W M-182$ & 735 & $83 ?$ & WM- 185 & 151 & $81^{\circ}$ & WM-187 & 5751 & $82{ }^{\circ}$ & 622 & 2.2 & & 34.2 & 1920 \\
\hline $\mathrm{H}-3$ & 14 & 7 & 911 & 202 & WM-182 & 748 & $83 \mid$ & WM-185 & 200 & 81 & WM-187 & 786 & 82 & 564 & 2.2 & & 33.9 & 1920 \\
\hline $\mathrm{H}-3$ & 15 & $7 !$ & 91 & 203 & WM-182 & $758^{\circ}$ & $83 i$ & WM- 185 & 211 & 81 & WM- 187 & 807 & 82 & 563 & 2.21 & & 34.11 & 2000 \\
\hline $\mathrm{H}-3$ & 16 & $7 !$ & 91 & 204 & WM-182 & $055^{\circ}$ & $83 i$ & WM-185 & $182 !$ & 81 & WM- 187 & 693 & 82 & 504 & 2.2 & & 327 & 1680 \\
\hline $\mathrm{H}-3$ & 16 & 7 & 91 & 205 & WM-182 & 927 & 83. & WM- 185 & $190 !$ & 81 & WM-187 & 724 & 82 & 388 & 2.2 & & 33.6 & 1760 \\
\hline $\mathrm{H}-3$ & 17 & $7 !$ & 91 & 200 & WM-18I & 930 & 831 & $W M-185$ & 212 & 81 & $W \bar{M}-187$ & 808 & 82 & 374 & 2.2 & & $34.0 !$ & 2000 \\
\hline $11-3$ & 18 & $7 i$ & $9 !$ & 207 & WM-182 & 946 & 83 & WM- 185 & 201 & 81 & WM-187 & 767 & 82 & 382 & $2.2 i$ & & 34.8 & 1840 \\
\hline $\mathrm{H}-3$ & 19 & $7 !$ & 91 & 208 & WM-182 & 938 & $83 T$ & 18.5 & 206 & 81 & WM-187 & 786 & 82 & 384 & 2.2 & & 32.3 & 1920 \\
\hline $\mathrm{H}-3$ & $20 !$ & 7 & 91 & 209 & WM-182 & 957 & $83 \uparrow$ & $W M-185$ & 233 & 81 & WM-187 & 888 & 82 & 373 & 2.2 & & $34.0 \%$ & 2160 \\
\hline $\mathrm{H}-3$ & 21 & 7 & 91 & 210 & $W M-182$ & 957 & 831 & $W M-185$ & 210 & 81 & WM-187 & 80,3 & 82 & 369 & 2.2 & & 34.3 & 2000 \\
\hline $\mathrm{H}-3$ & 211 & 7 & 91 & 211 & WM-182 & 941 & 83 & WM-185 & 208 & 81 & WM-187 & 793 & 82 & 418 & 2.2 & & 34.3 & 2000 \\
\hline $\mathrm{H}-3$ & 23 & 7 & 911 & 212 & WM-182 & 950 & 831 & -185 & 207 & 81 & WM- 187 & 791 & 82 & 394 & $2.2 !$ & & 34.8 & 2000 \\
\hline $11-3$ & 24 & 7 & $9 !$ & 213 & $M-182$ & 1.330 & 831 & 85 & 207 & 81 & WM-187 & 789 & 82 & & & & 33.5 & 2000 \\
\hline $\mathrm{H}-3$ & 24 & $7 !$ & 91 & 214 & WM-182 & 1269 & 831 & 185 & 236 & 81 & WM-187 & 764 & 82 & & & & 3111 & 1920) \\
\hline $\mathrm{H}-3$ & $25:$ & $7^{1}$ & 91 & 215 & WM-I82 & 1308 & 831 & W & 243 & 81 & WM- 187 & 786 & 82 & & & & 335 & 2000 \\
\hline $\mathrm{H}-3$ & 26 & 7 & 91 & 210 & $4-182$ & 1281 & 831 & -185 & 239 & 81 & 187 & 772 & 82 & & & & $32.0^{\circ}$ & 1920 \\
\hline $\mathrm{H}-3$ & 27 & 7 & 91 & 217 & M-182 & 311 & $83\}$ & WM- 185 & 243 & 81 & -187 & 785 & 82 & & & & 32.0 & 2000 \\
\hline $\mathrm{H}-3$ & 27 & 7 & 91 & 218 & M-182 & 1285 & 83 & WM-185 & 248 & 81 & WM-187 & 802 & 82 & & & & $328 !$ & 2000 \\
\hline $\mathrm{H}-3$ & 27 & 7 & 91 & 219 & 22 & 311 & 83 & WM-185 & 243 & 81 & 187 & 787 & 82 & & & & 32.4 & 20000 \\
\hline $\mathrm{H}-3$ & 20 & 7 & $9 !$ & 220 & WM-182 & 1217 & 831 & $W M-18.5$ & 224 & 81 & $W M-187$ & 725 & 82 & & & & 310 & 1840 \\
\hline $\mathrm{H}-3$ & 30 & 7 & 91 & 221 & $W M-182$ & 232 & 83 & WM- 185 & 230 & 81 & WM- 187 & 744 & 82 & & & & 34.4 & 1920 \\
\hline 11.3 & 30 & 7 & 91 & 222 & 8 & 306 & 83 & $w 1$ & 238 & 81 & WM 187 & $770^{t}$ & 82 & & & & 31.8 & 2000 \\
\hline $11-3$ & 31 & 7 & 91 & 223 & $W M-182$ & 302 & 834 & WM-185 & $238^{\circ}$ & 81 & WM-187 & 771 & 82 & & & & 33.0 & 1920 \\
\hline $\mathrm{H}-3$ & 1 & 8 & $91^{\circ}$ & 224 & WM- 182 & 1311 & $83 \pi$ & WM- 185 & $244^{\circ}$ & 81 & WM-187 & 789 & 82 & & & & 31.0 & 2000 \\
\hline 113 & 2 & 8 & 91 & 225 & $M-182$ & 1281 & 831 & WM-185 & 241 & 81 & WM-187 & 781 & 82 & & & & 32.3 & 2000 \\
\hline $\mathrm{H}-3$ & 2 & $8 !$ & 91 & 226 & $4-182$ & 1290 & 831 & $W N$ & 246 & 81 & -187 & $785^{\circ}$ & $82 !$ & & & & 30.5 & 2000 \\
\hline $\mathrm{H}-3$ & 3 & 8 & 91 & 227 & WM-182 & 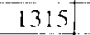 & 831 & WM-185 & 246 & 81 & $\bar{W}-187$ & 797 & 82 & & & & .33 .6 & 2000 \\
\hline HI-3 & 4 & 8 & 91 & 228 & WM-182 & 1287 & 8315 & WM -185 & $236 !$ & 81 & $W M-187$ & 764 & $82 !^{\circ}$ & & & & 32.6 & 1920 \\
\hline $\mathrm{H}-3$ & 4 & 8 & 91 & 229 & $W M-J 82$ & 1316 & 83.1 & WM1-185 & 244 & 81 & $W M-187$ & 790 & $82 !$ & & & & 324 & 2000 \\
\hline $\mathrm{H}-3$ & 5 & $8 !$ & $91 !$ & 230 & $4-182$ & 1283 & $83: 1$ & WM-185 & $238^{4}$ & 81 & WM-187 & 771 & 821 & & & & 33.0 & $1 \% 20$ \\
\hline $\mathrm{H} \cdot 3$ & 6 & 8 & 91 & 231 & WM-182 & 1004 & 8311 & WM- 185 & 198 & 817 & WM- 187 & 642 & $82 !$ & 590 & 2.2 & & $292 !$ & 159 \\
\hline $\mathrm{H}-3$ & 15 & 8 & 91 & DB & & anprox & $\mathrm{da}$ & cul & & & & 7014 & $9=$ & & & & & \\
\hline $\mathrm{H}-3$ & 16 & 8 & 91 & DB & Dolomite B & approx & $.35 \mathrm{cul}$ & bic feel & & & & 2478 & 92 & & & & & \\
\hline
\end{tabular}


Table A5. Calciner Feed to Calcined Solids Storage Facility V. (continued)

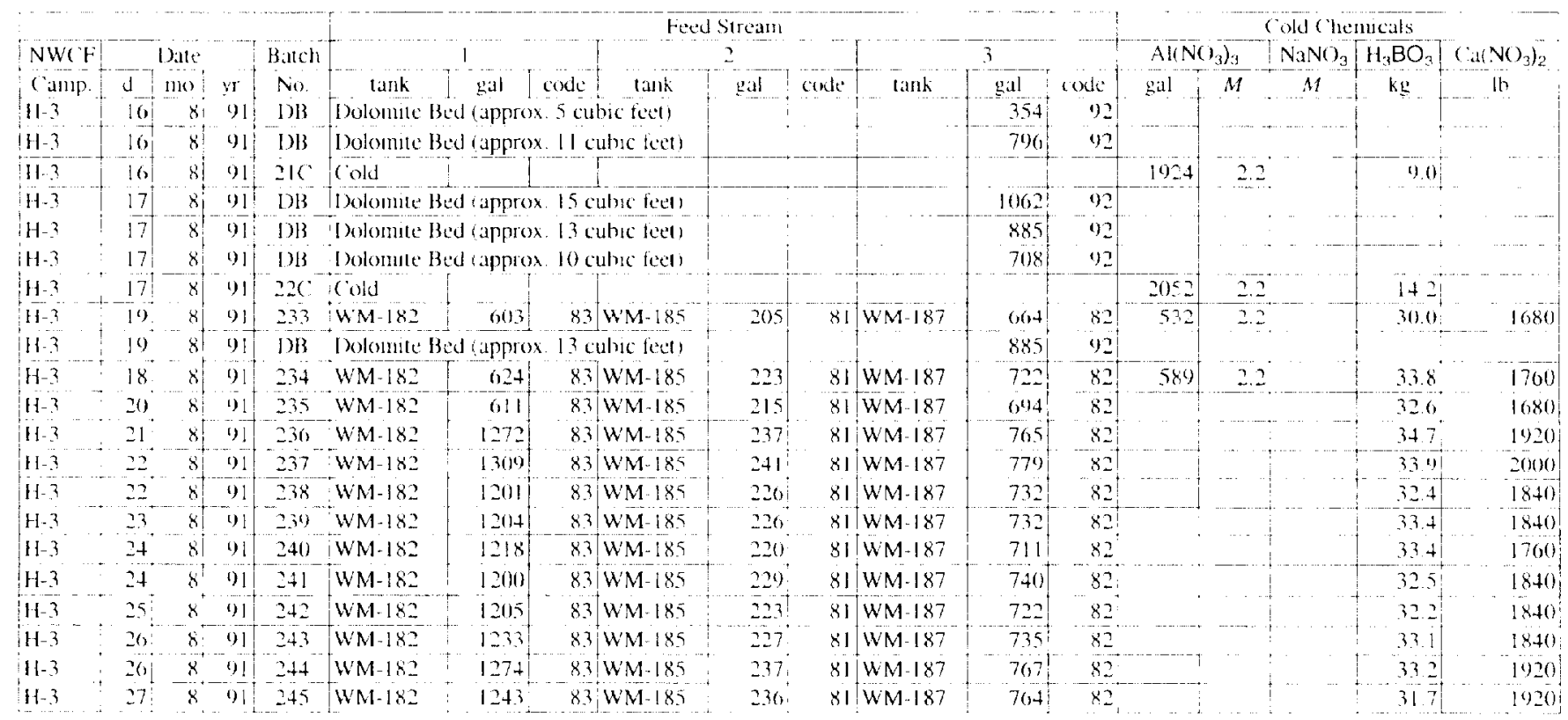


page intentionally blank 
Table A6. Calciner Feed to Calcined Solids Storage Facility VI.

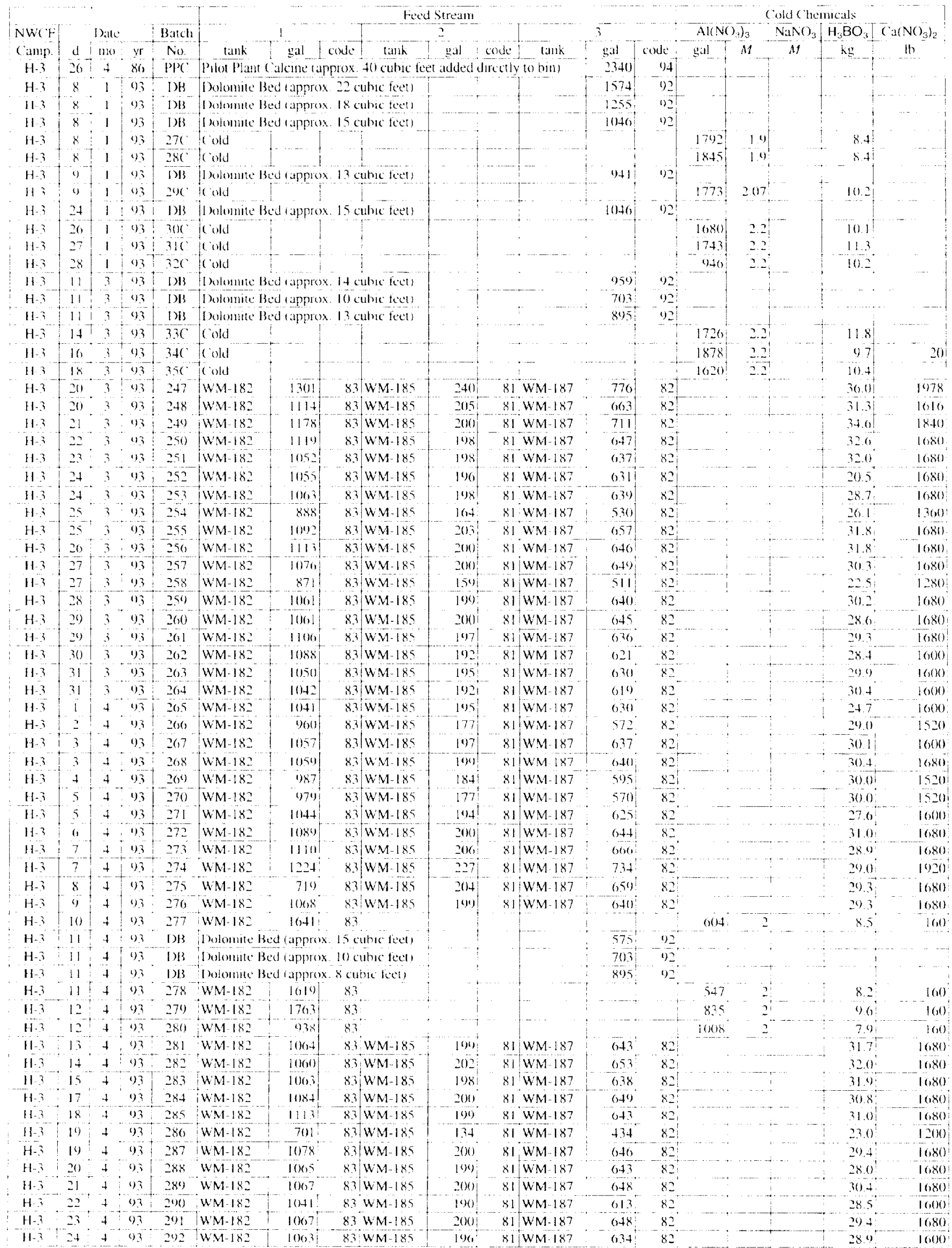


Table A6. Calciner Feed to Calcined Solids Storage Facility VI. (continued)

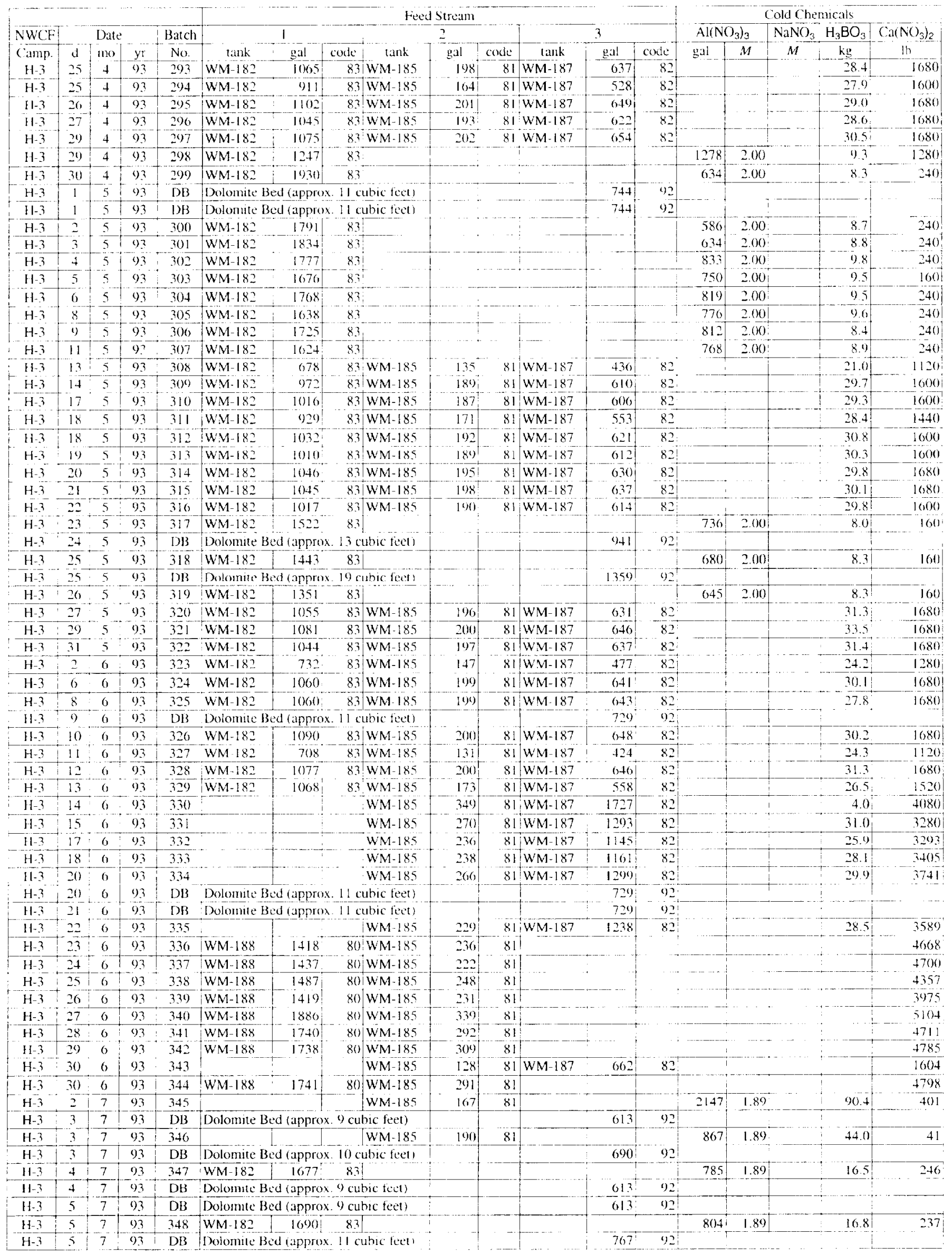


Table A6. Calciner Feed to Calcined Solids Storage Facility VI. (continued)

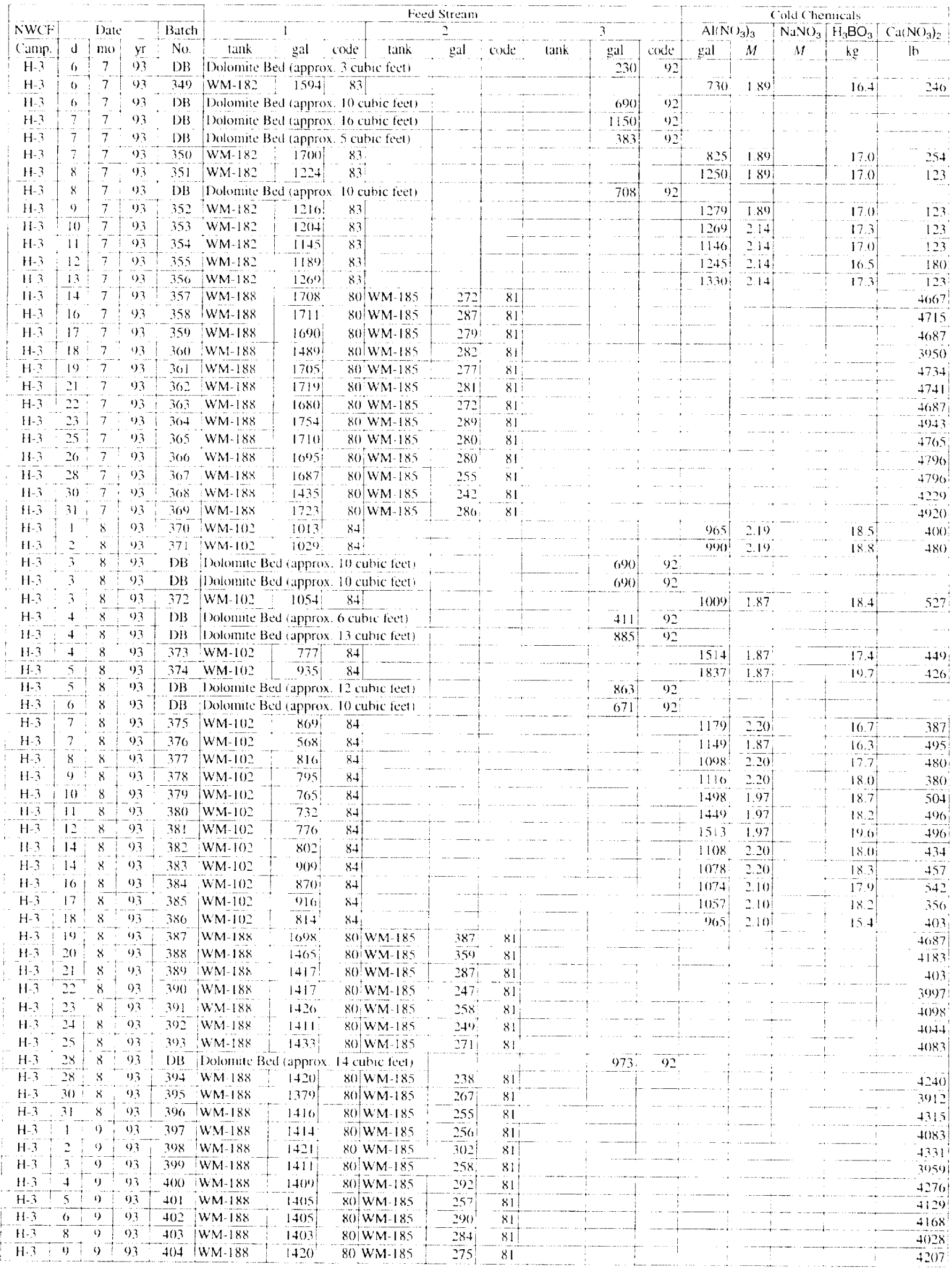


Table A6. Calciner Feed to Calcined Solids Storage Facility VI. (continued)

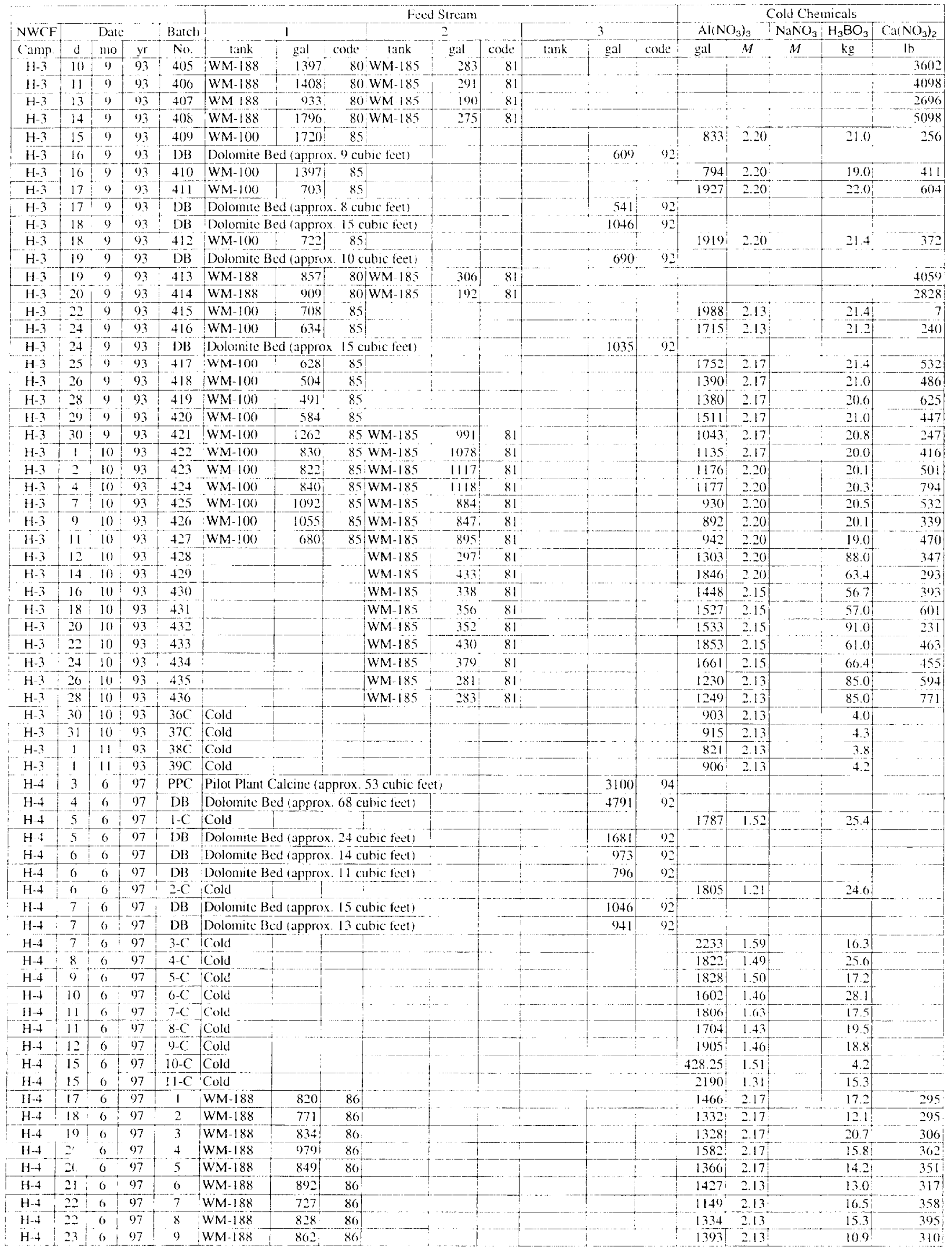


Table A6. Cakciner Feed to Calcined Solids Storage Facility VI. (continued)

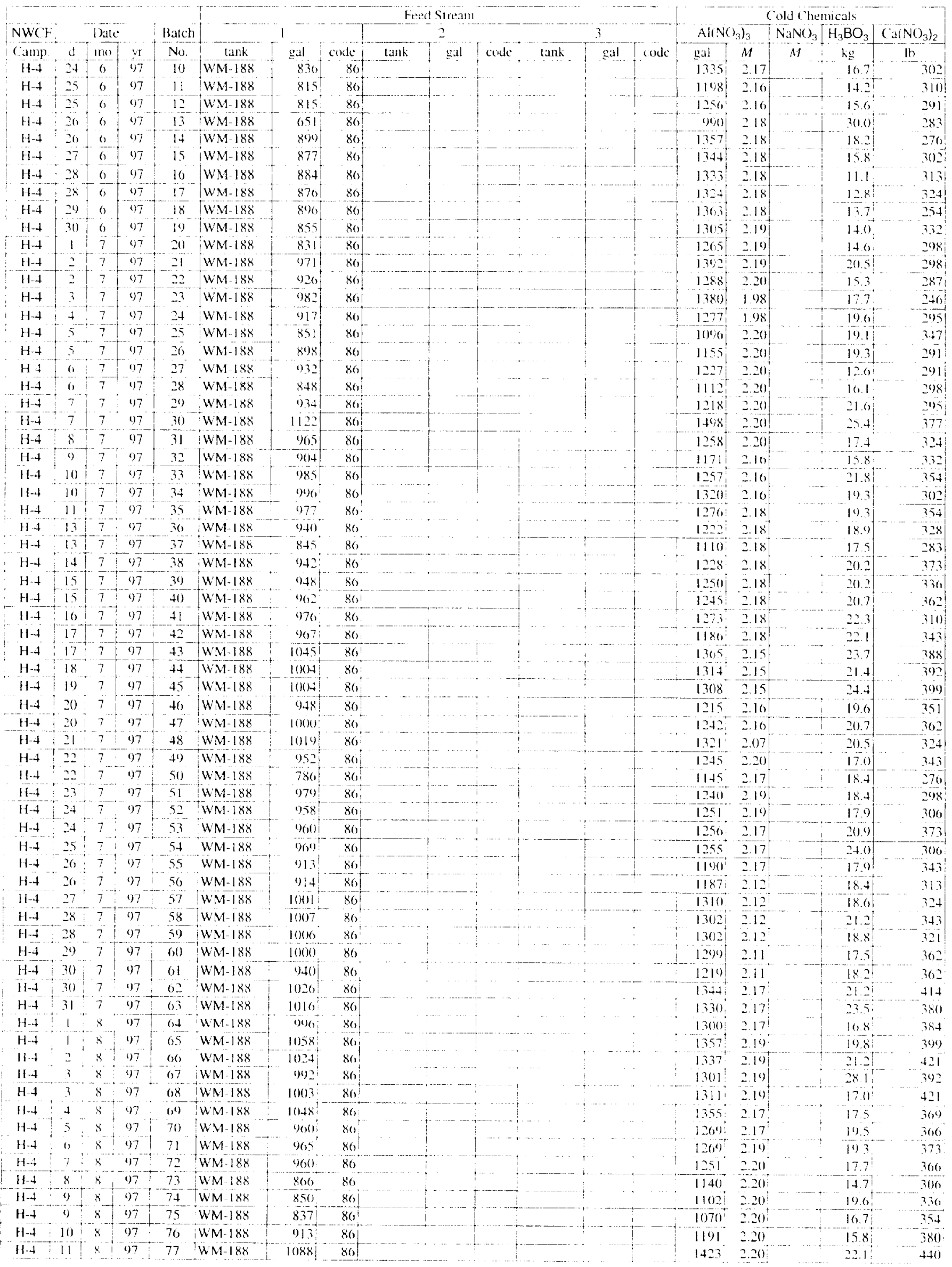


Table A6. Calciner Feed to Calcined Solids Storage Facility VI. (continued)

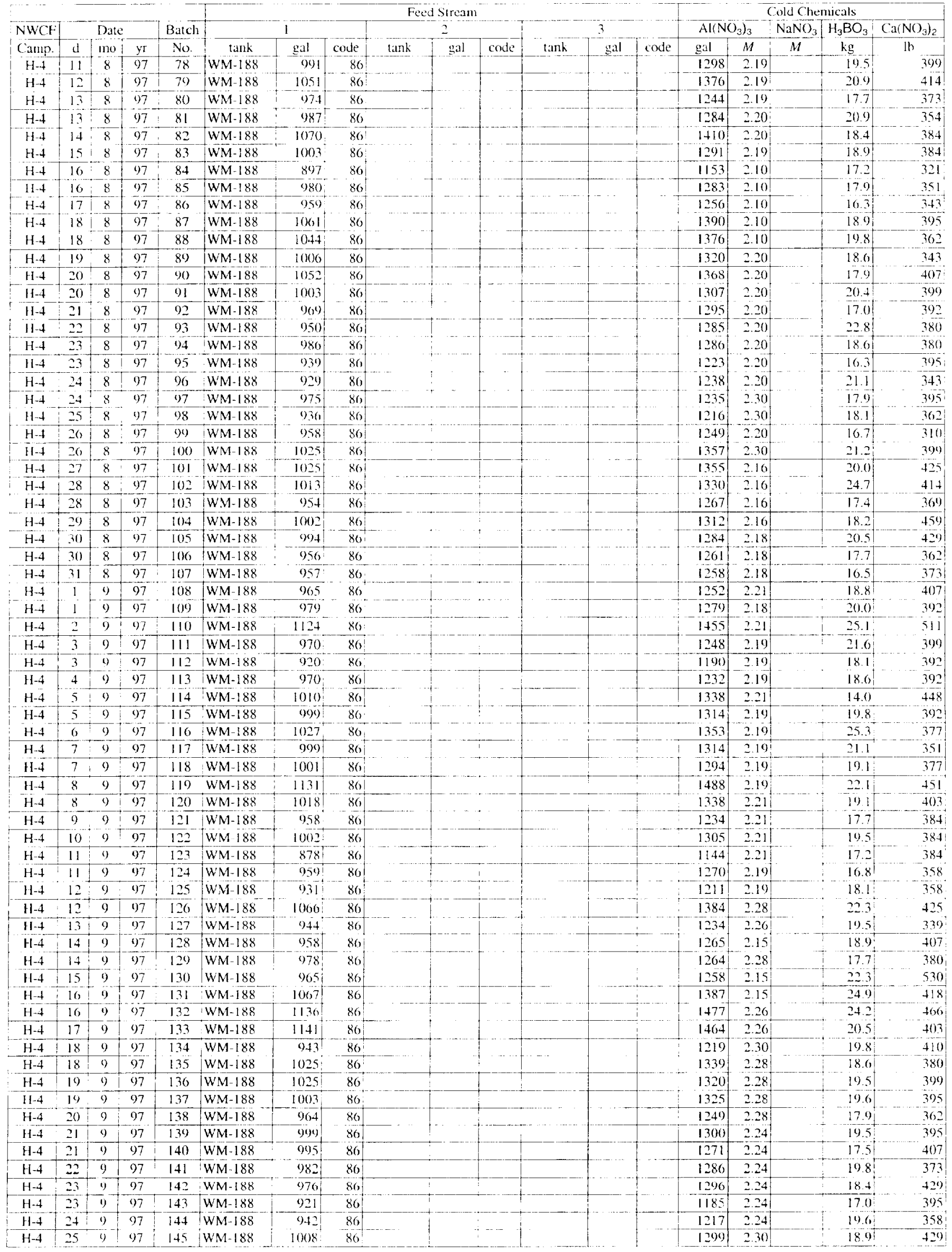


Table A6. Calciner Feed to Calcined Solids Storage Facility V'I. (continued)

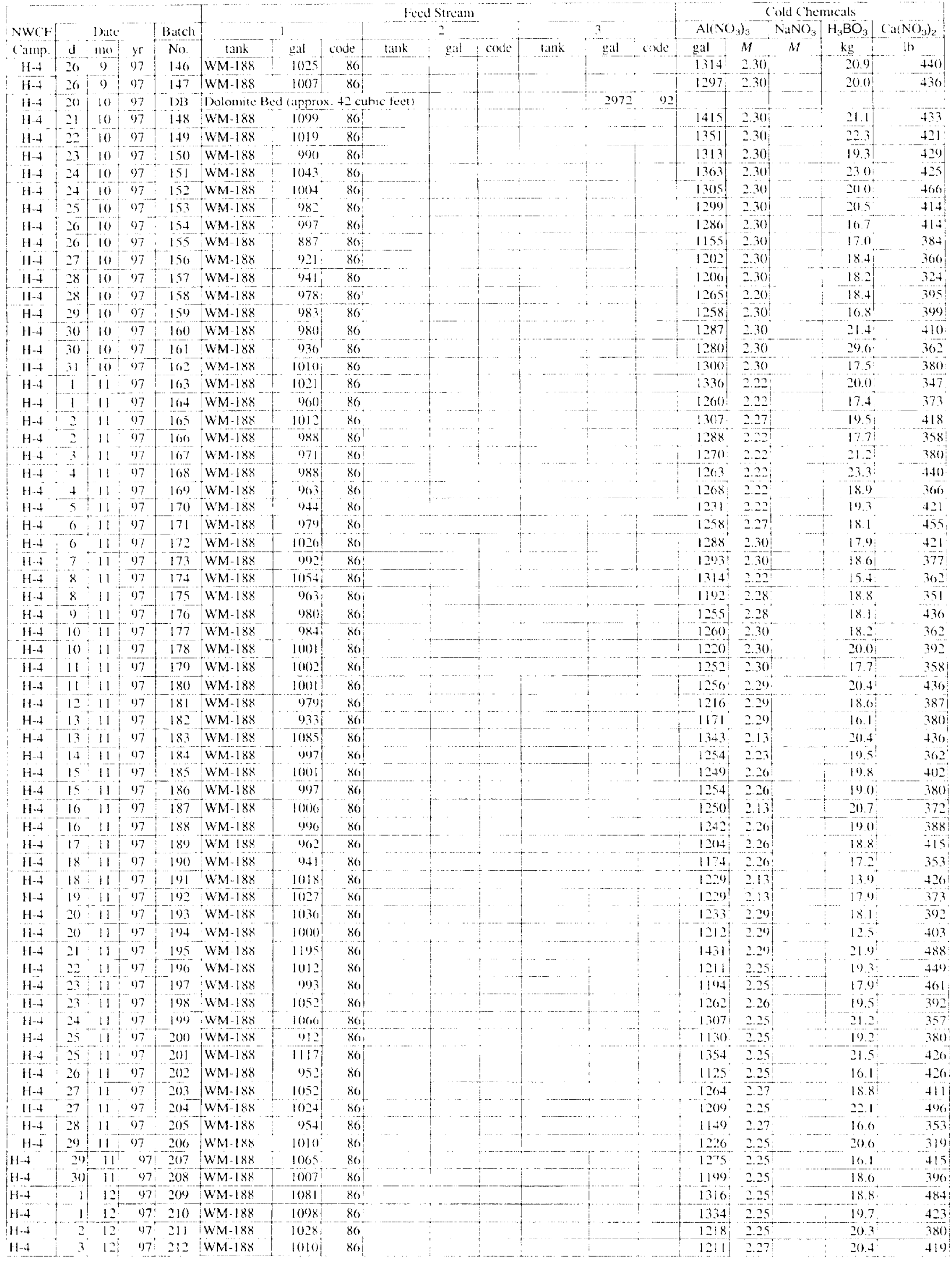


Table A6. Calciner Feed to Calcined Solids Storage Facility VI. (continued)

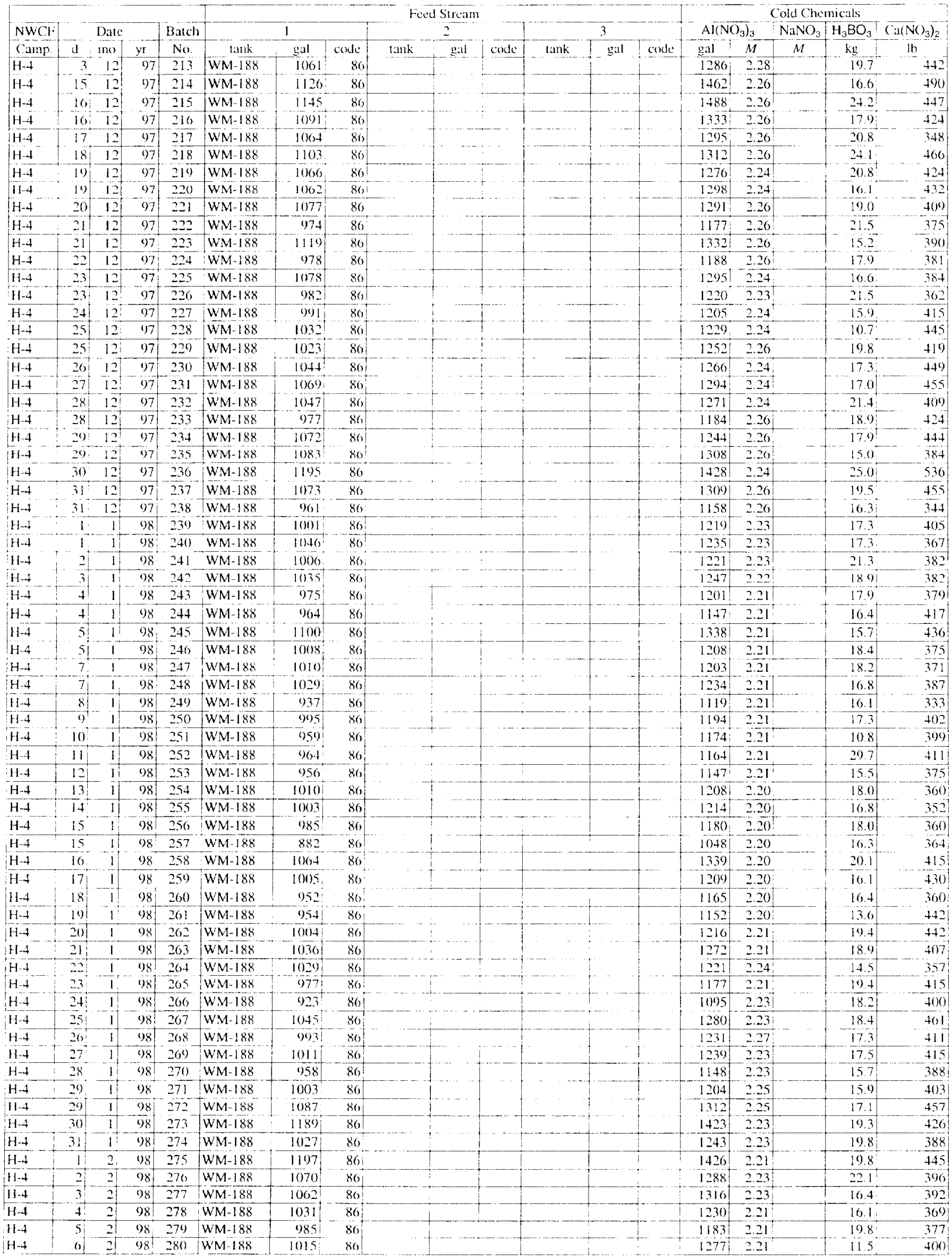


Table A6. Calciner Feed to Calcined Solids Storage Facility VI. (continued)

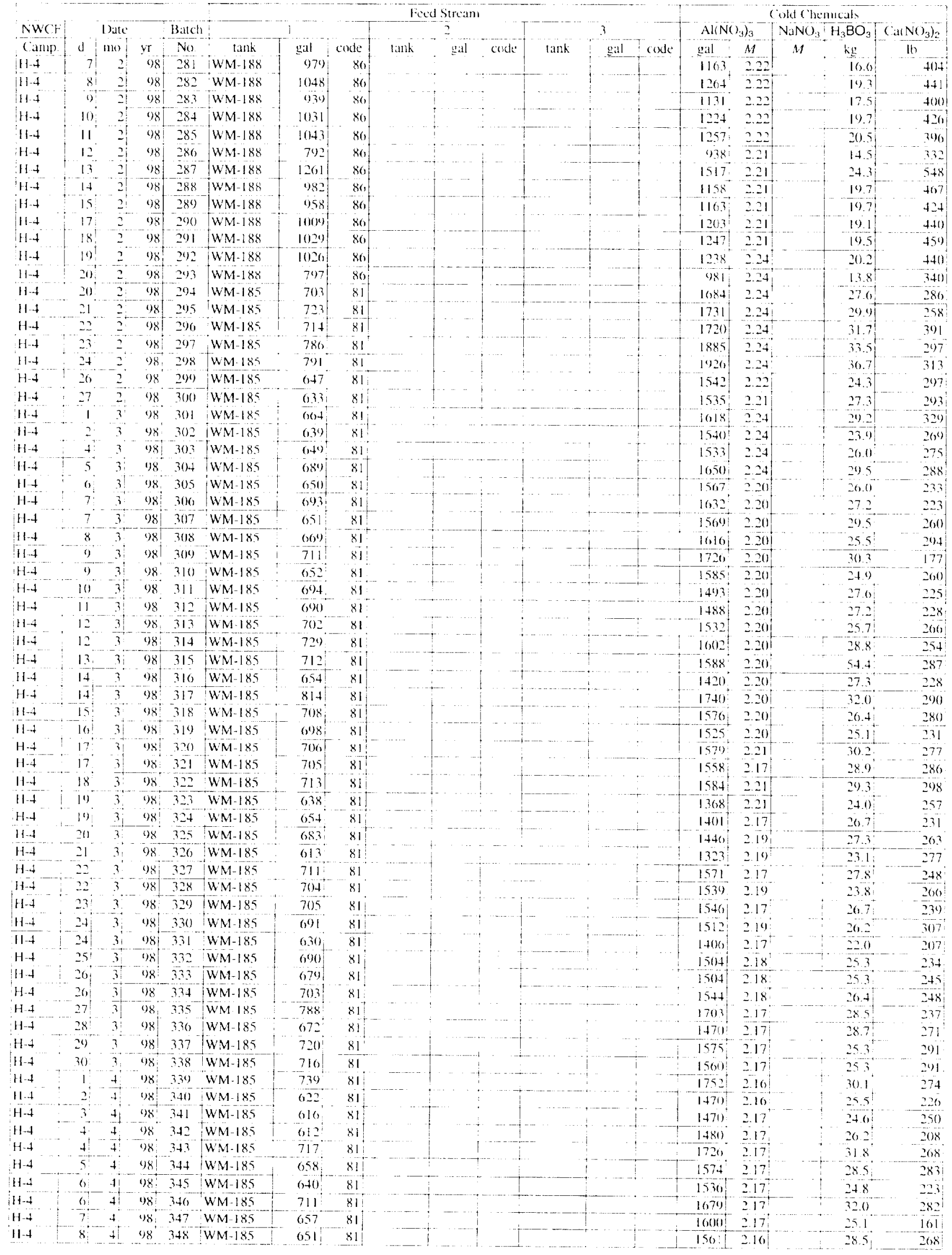


Table A6. Calciner Feed to Calcined Solids Storage Facility VI. (continued)

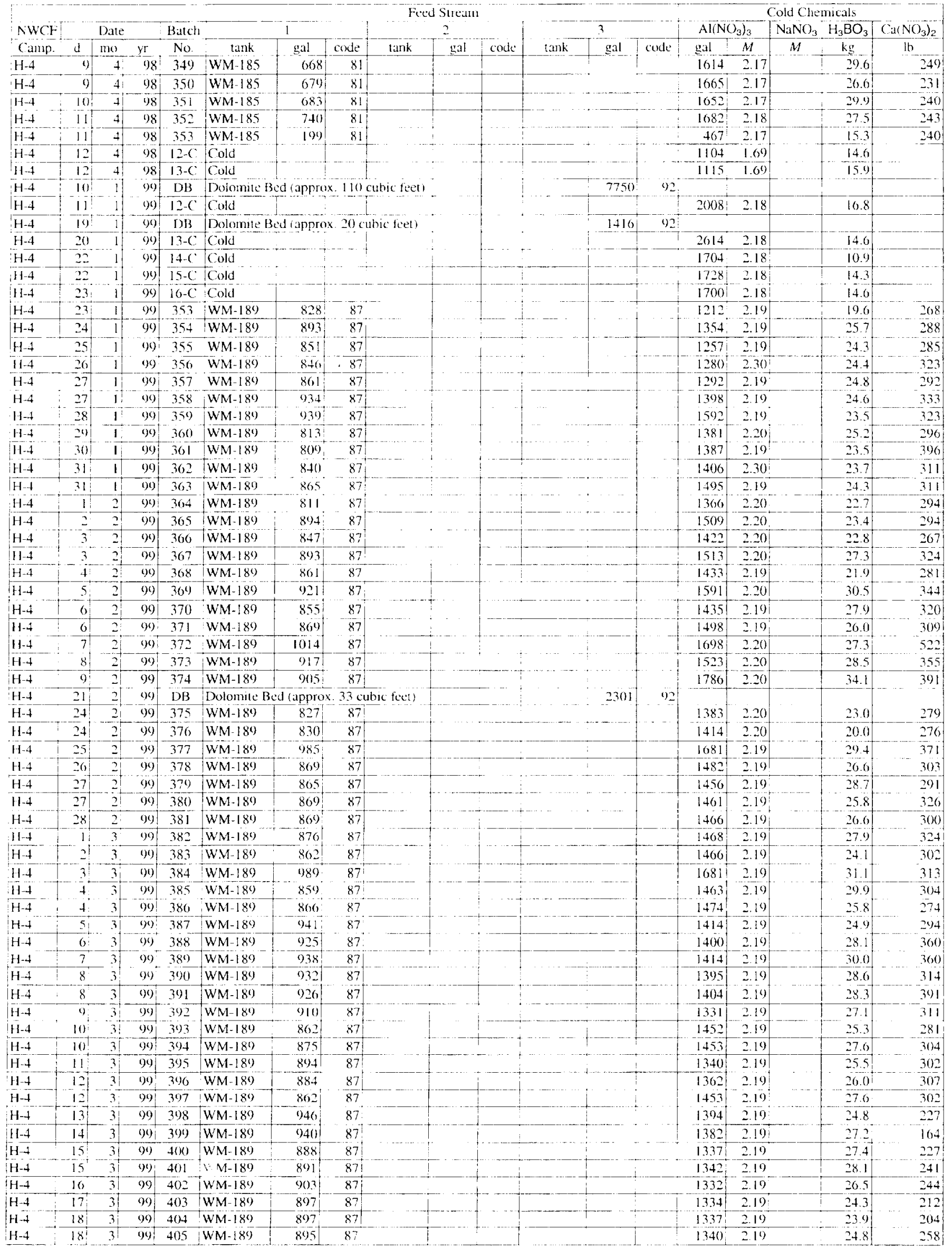


Table A6. Calciner Feed to Calcined Solids Storage Facility VI. (continued)

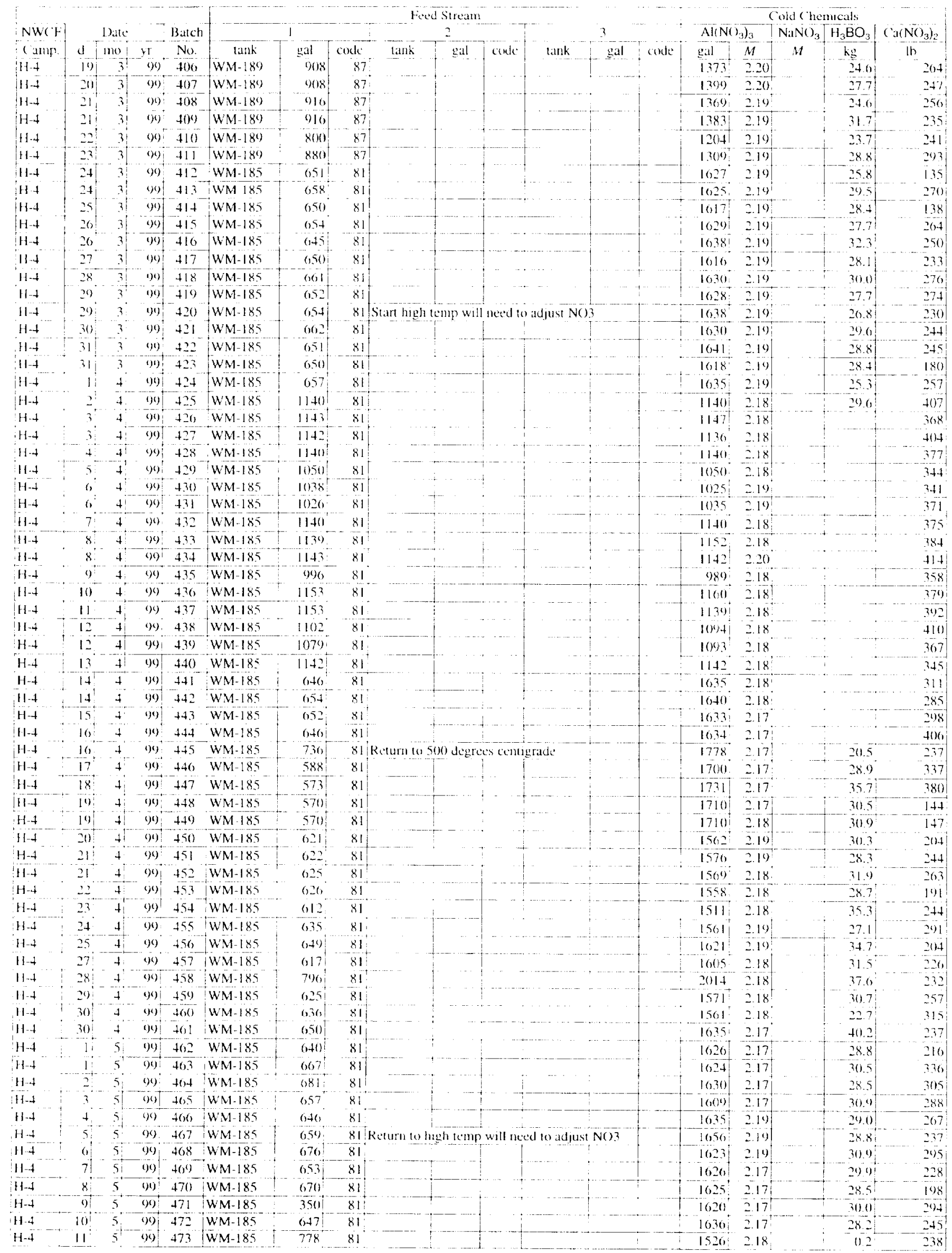


Table A6. Calciner Feed to Calcined Solids Storage Facility VI. (continued)

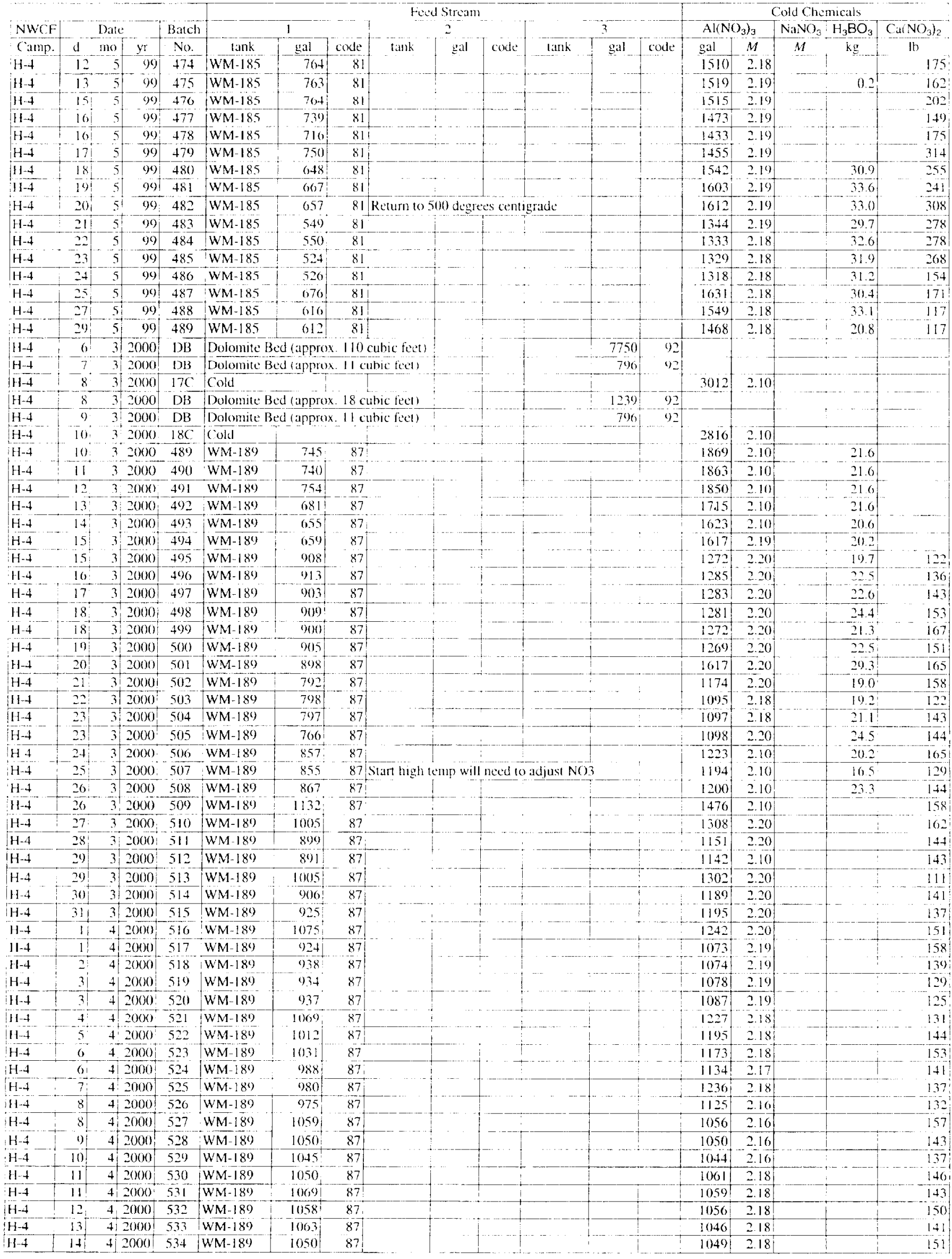


Table Ao. Calciner Feed to Calcined Solids Storage Facility VI. (continued)

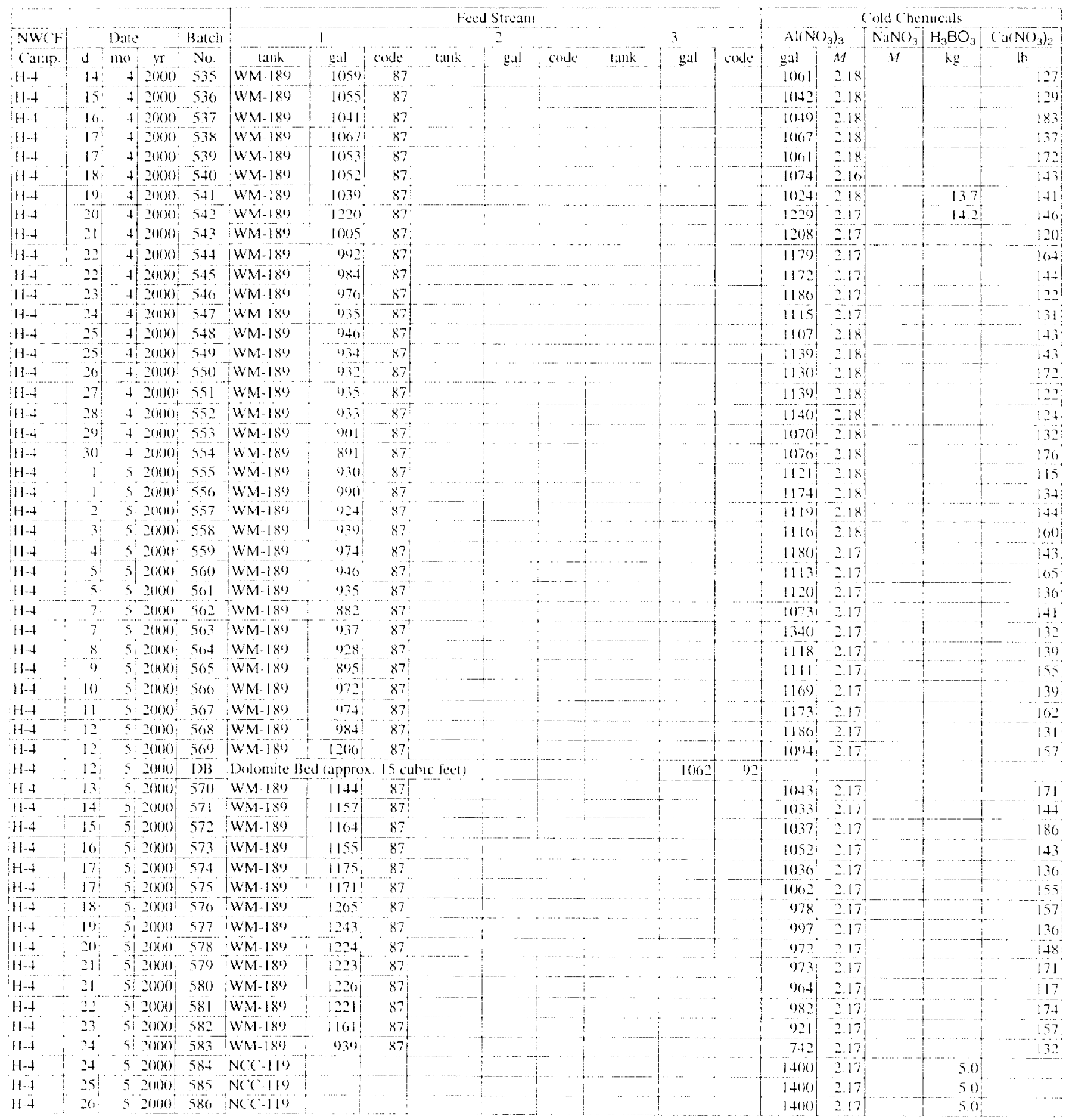


page intentionally blank

A-106 